Biomonitoring of Environmental Status and Trends (BEST) Program: Environmental Contaminants, Health Indicators, and Reproductive Biomarkers in Fish from the Colorado River Basin

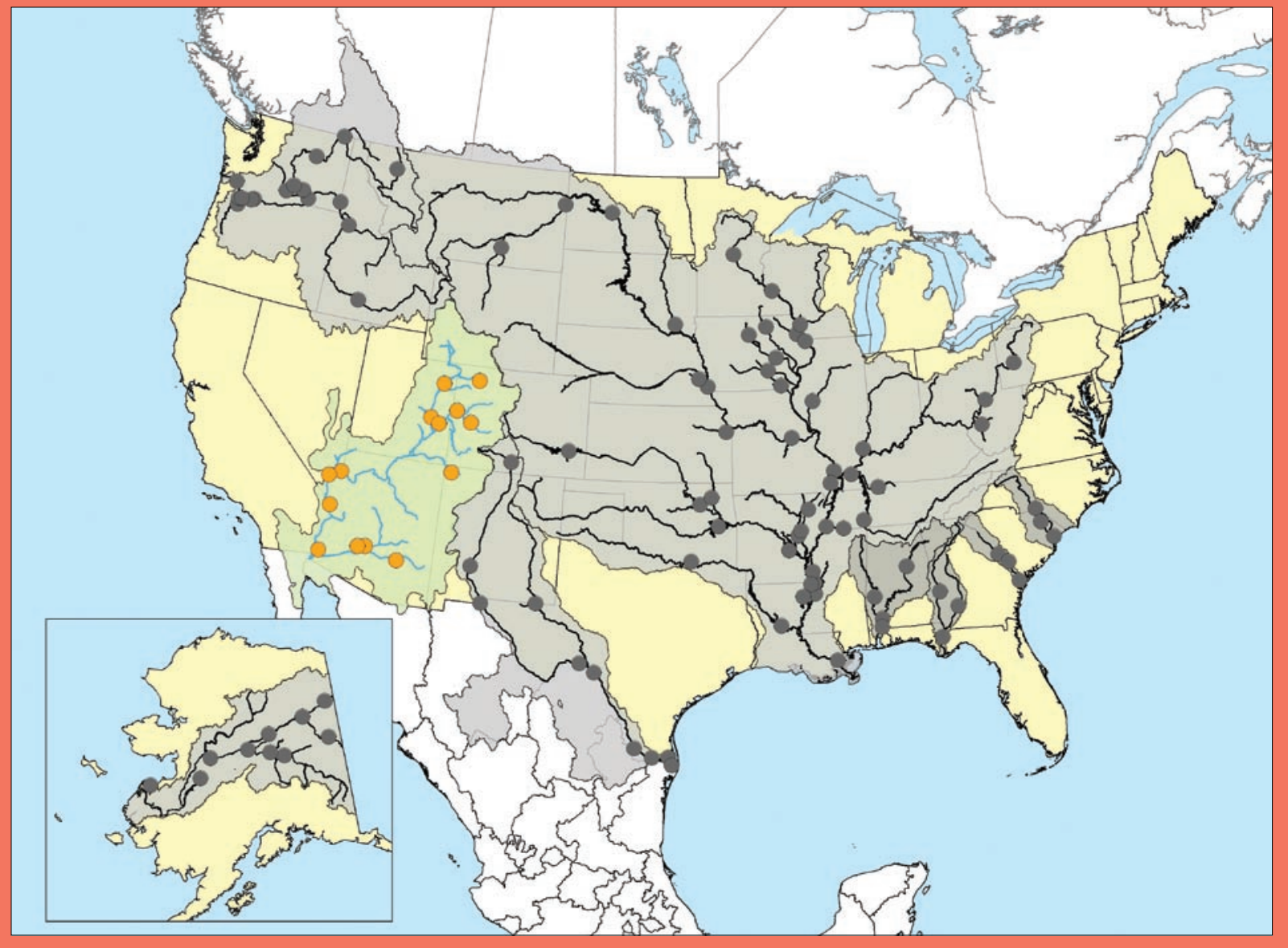

Scientific Investigations Report 2006-5163 
Cover: The U.S. map shows the Colorado River Basin (green) and stations sampled during this study (orange). Shown in gray are major river basins and stations in the conterminous U.S. and Alaska sampled during Biomonitoring of Environmental Status and Trends Program (BEST) investigations. 


\section{Biomonitoring of Environmental Status and Trends (BEST) Program: Environmental Contaminants, Health Indicators, and Reproductive Biomarkers in Fish from the Colorado River Basin}

By Jo Ellen Hinck, Vicki S. Blazer, Nancy D. Denslow, Timothy S. Gross, Kathy R. Echols, Anne P. Davis, Tom W. May, Carl E. Orazio, James J. Coyle, and Donald E. Tillitt

Scientific Investigations Report 2006-5163

U.S. Department of the Interior

U.S. Geological Survey 


\section{U.S. Department of the Interior \\ Dirk Kempthorne, Secretary \\ U.S. Geological Survey \\ P. Patrick Leahy, Acting Director}

\section{U.S. Geological Survey, Reston, Virginia: 2006}

For product and ordering information:

World Wide Web: http://www.usgs.gov/pubprod

Telephone: 1-888-ASK-USGS

For more information on the USGS--the Federal source for science about the Earth, its natural and living resources, natural hazards, and the environment:

World Wide Web: http://www.usgs.gov

Telephone: 1-888-ASK-USGS

Any use of trade, product, or firm names is for descriptive purposes only and does not imply endorsement by the U.S. Government.

Although this report is in the public domain, permission must be secured from the individual copyright owners to reproduce any copyrighted materials contained within this report.

Suggested citation:

Hinck, J.E., Blazer, V.S., Denslow, N.D., Gross, T.S., Echols, K.R., Davis, A.P., May, T.W., Orazio, C.E., Coyle, J.J., and Tillitt, D.E., 2006, Biomonitoring of Environmental Status and Trends (BEST) Program: environmental contaminants, health indicators, and reproductive biomarkers in fish from the Colorado River Basin: U.S. Geological Survey, Scientific Investigations Report 2006-5163, 119 p. 


\section{Preface}

This study was conducted as part of the U.S. Geological Survey (USGS) Biomonitoring of Environmental Status and Trends (BEST) Program's Large River Monitoring Network (LRMN). BEST evolved from previous Federal monitoring programs including the National Pesticide Monitoring Program (NPMP) of the 1960s, renamed the National Contaminant Biomonitoring Program (NCBP) in the early 1970s, which also screened for elemental contaminants. The U.S. Fish and Wildlife Service (USFWS) participated in the NPMP and maintained the NCBP by monitoring concentrations of persistent contaminants in freshwater fish and avian wildlife through 1986 (Schmitt and others, 1999). The BEST Program was initiated in the 1990s to build on information produced by these earlier programs and to provide more biologically relevant information regarding potential contaminant effects on lands and species under USFWS management. The program was transferred to the National Biological Survey in 1993 and ultimately to USGS in 1996. The LRMN has principal emphasis to identify, monitor, and assess the effects of chemical contaminants on the fish health in the nation's large rivers. The 2003 Colorado River Basin (CDRB) study is one in a series of BEST-LRMN Program monitoring investigations. Previous studies include the Mississippi River Basin in 1995, the Columbia River and Rio Grande Basins in 1997, and the Yukon River Basin in 2002.

\section{Acknowledgements}

This study was conducted jointly by the USGS through its research centers in Columbia, Missouri (Columbia Environmental Research Center, CERC), Gainesville, Florida (Florida Integrated Science Center, FISC), and Kearneysville, West Virginia (Leetown Science Center, LSC). The study was facilitated through a Research Work Order with the USGS-Florida Cooperative Fish and Wild life Research Unit at the University of Florida (UF), Gainesville, Florida. The U.S. Fish and Wildlife Service (USFWS) offices in Salt Lake City, Utah; Vernal, Utah; Grand Junction, Colorado; Albuquerque, New Mexico; Las Vegas, Nevada; Phoenix, Arizona; Parker, Arizona; and Willow Beach, Arizona participated in fish collections. California Department of Fish and Game in Blythe, California and the Colorado Division of Wildlife in Fort Collins, Colorado also collected fish. Many individuals representing USGS, USFWS, UF, and other organizations contributed substantially during the conduct of the study. M. Annis (CERC), P. Anderson [BEST Program, (BEST)], D. Baker (USFWS), T. Bartish (BEST), J. Candrl (CERC), J. Coyle (BEST), L.R. DeWeese (USGS National Water Quality Assessment (NAWQA) Program), S. Goodbred (NAWQA), D. Nicks (CERC), C. Marr (USFWS), E. Orsak (USFWS), and D. Papoulias (CERC) participated in field dissections. Chemical analyses were conducted by CERC Environmental Chemistry laboratories (B. Brumbaugh, K. Feltz, J. Meadows, M. Tanner, G. Tegerdine, and M. Walther). Laboratory analyses for biomarkers were performed by D. Nicks, A. Donahue, C. Wieser (FISC), D. Bowling (LSC), and K. Kroll (UF). D. Bowling (LSC) and K. Spring (LSC) assisted in the histology slide preparation, and B. Martin (LSC) assisted with the macrophage aggregate evaluation for samples from Stations 311, 313, 314, 316, 317, 321, 322, 323, and 325. C. Smith (Colorado Histo-Prep, Fort

Collins, Colorado) analyzed the histology samples from Stations 312, 315, 319, 320, and 324. L. Stanley (Tottenham, Ontario) and J. Isely (USGS Coop Unit, Clemson University) aged the fish. R. Lipkin (CERC) prepared the report for publication. R. Claunch (CERC) and M. Keuss (CERC) provided quality assurance for tables and figures. S. Goodbred, K. Koch (Bureau of Land Management), C. Marr, and R. Patiño (USGS Coop Unit, Texas Tech University) reviewed the report and provided additional information. 


\section{Contents}

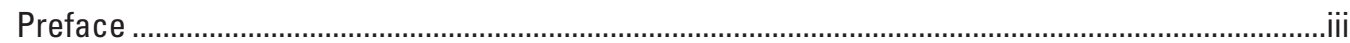

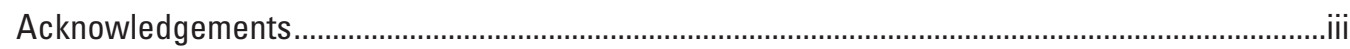

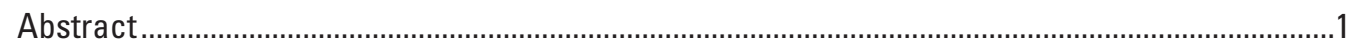

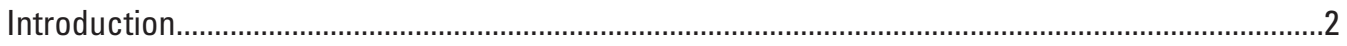

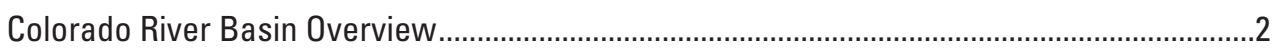

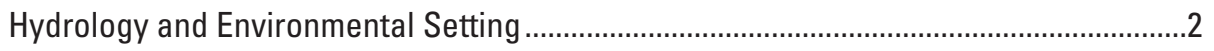

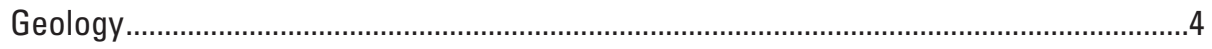

Landownership and Urban Areas ..............................................................................

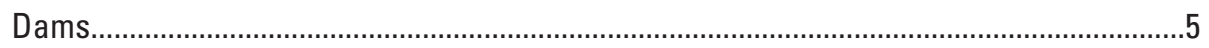

Water Quality Impairments and Fish Consumption Advisories.......................................5

Major Sources of Contaminants to the Colorado River Basin ...................................................

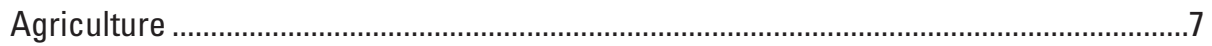

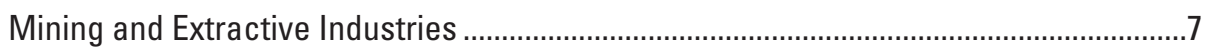

Industrial and Municipal Sources...........................................................................

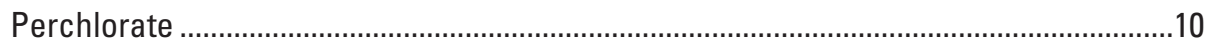

Extant Sources of Information on Contaminants in the Colorado River Basin .......................10

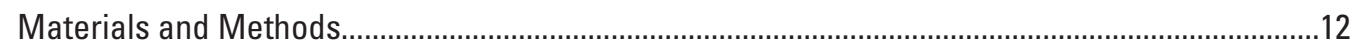

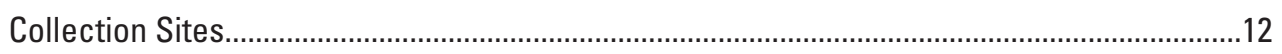

Target Species and Sampling Strategy .........................................................................12

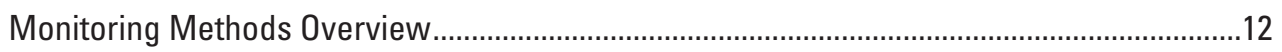

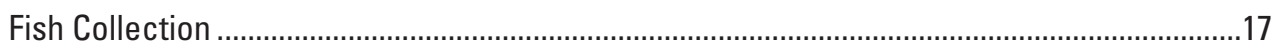

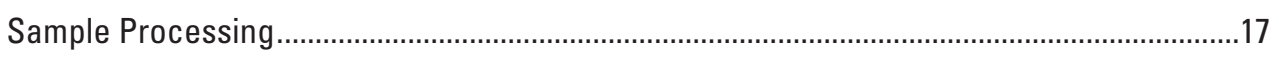

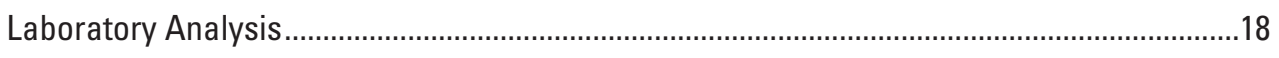

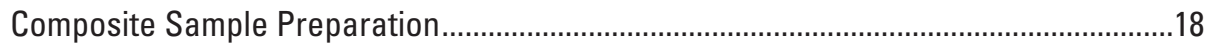

Elemental Contaminants and Moisture Content............................................................18

Organochlorine Contaminants and Lipid Content ......................................................19

H4IIE Rat Hepatoma Cell Bioassay ...............................................................................19

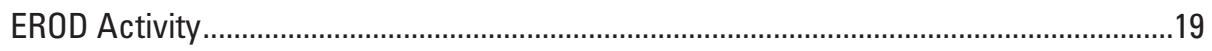

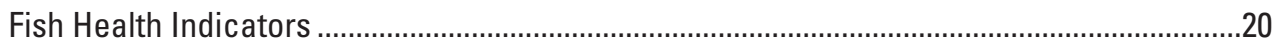

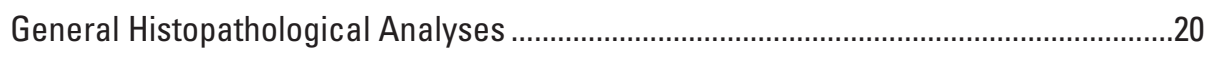

Quantitative Organism-Level Indicators ..................................................................20

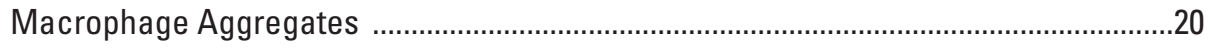

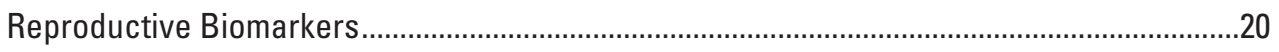

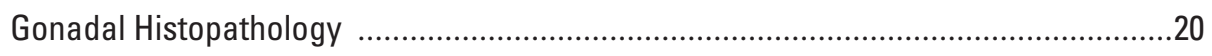

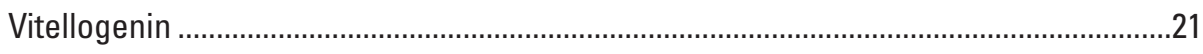

Sex Steroid Hormones .............................................................................................21

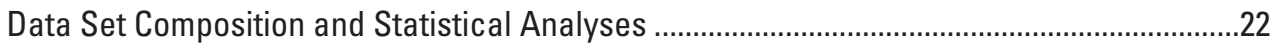

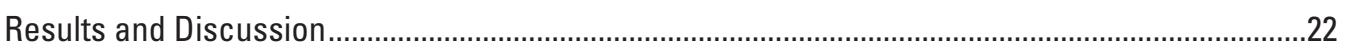

Geographic Distribution and Demographic Characteristics of the Fish Collected.................22

Accumulative contaminants, H4IIE Bioassay, and EROD Activity.........................................24

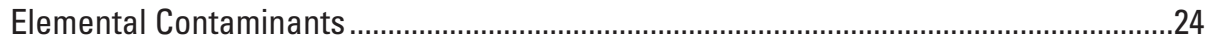

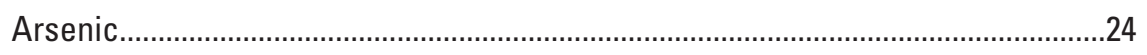

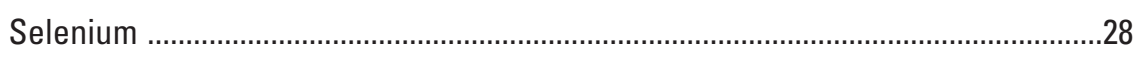

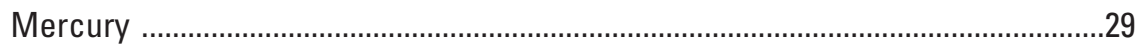

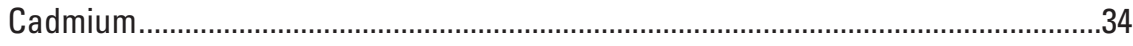




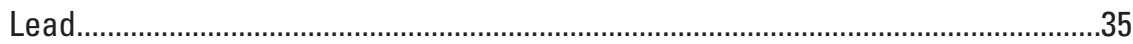

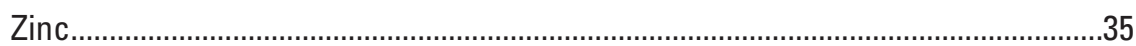

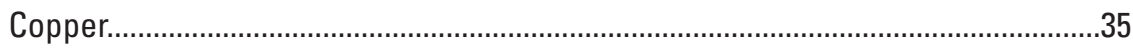

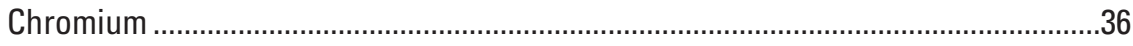

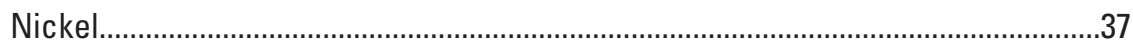

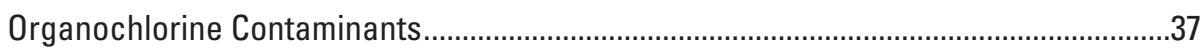

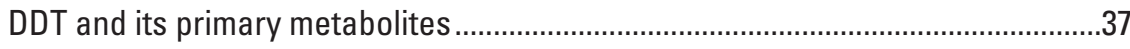

Chlordane and heptachlor................................................................................

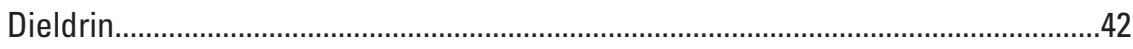

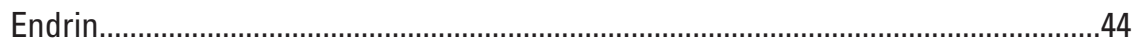

Mirex

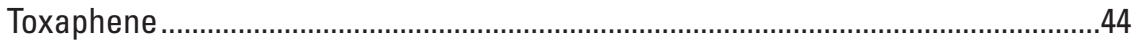

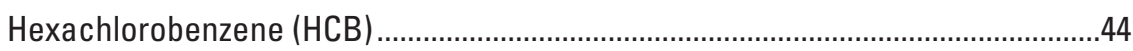

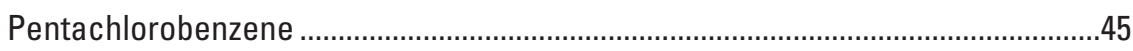

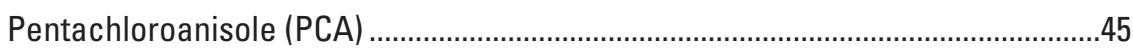

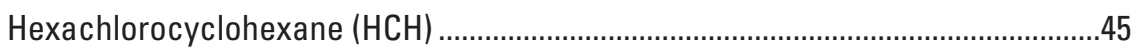

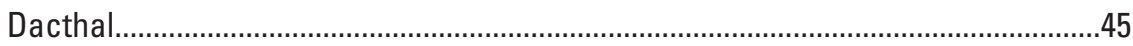

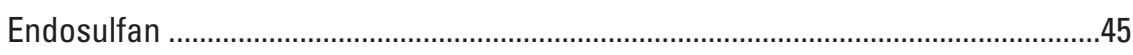

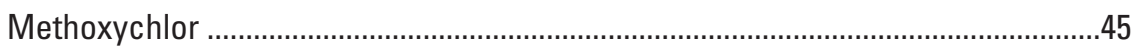

Total PCBs, H4IIE-Derived Dioxin Equivalents and Ethoxyresorufin O-Deethylase

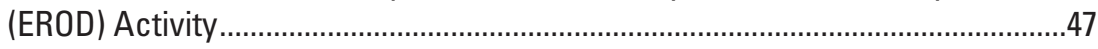

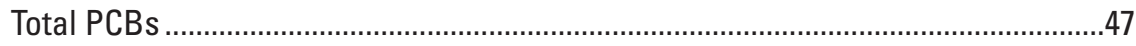

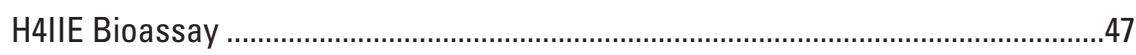

Ethoxyresorufin O-Deethylase (EROD) Activity ……..............................................48

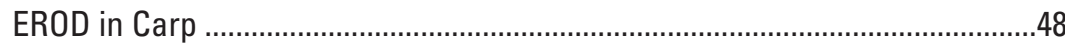

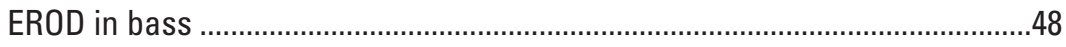

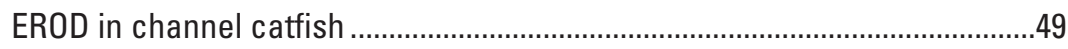

EROD in other species ............................................................................ 49

Accumulative Contaminants, H4IIE, and EROD Activity: Summary................................51

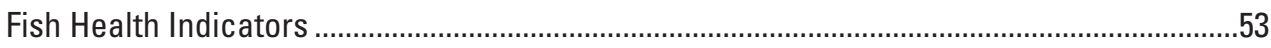

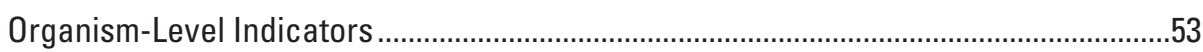

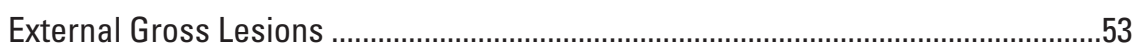

Health Assessment Index................................................................................53

Condition factor and Organosomatic Indices ...............................................................53

Condition factor and Organosomatic Indices in Carp .............................................53

Condition factor and Organosomatic Indices in Bass ............................................55

Condition factor and Organosomatic Indices in Channel catfish............................57

Cellular and Histopathological Indicators .................................................................59

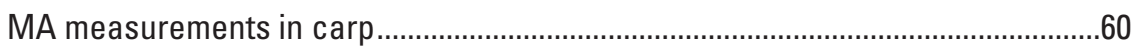

MA measurements in bass ............................................................................61

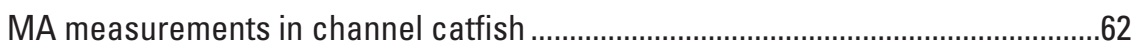

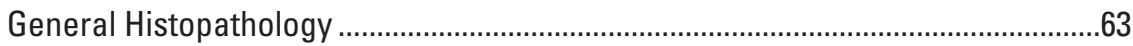

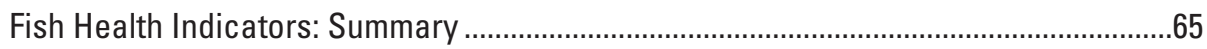

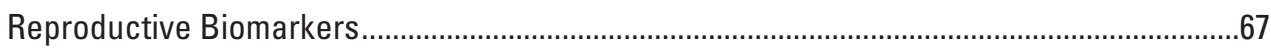

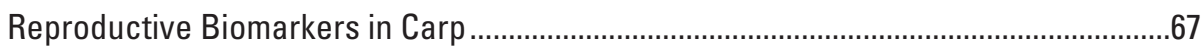

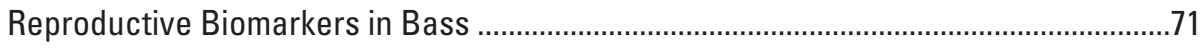

Reproductive Biomarkers in Channel catfish ............................................................77

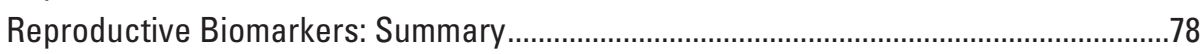


Spatial patterns in contaminant concentrations and biomarker responses ...........................80

Correlations between Chemical and Biological Endpoints ..........................................80

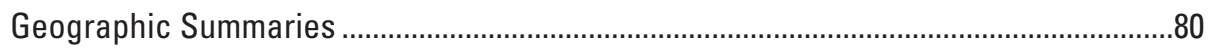

Upper Colorado River Basin (Upper CDRB)............................................................

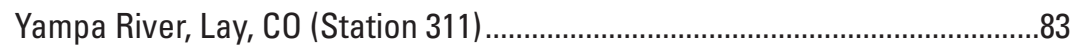

Green River, Ouray NWR, UT (Station 312) ...................................................83

Green River, San Rafael, UT (Station 313) ......................................................83

Gunnison River, Delta, CO (Station 314)..........................................................

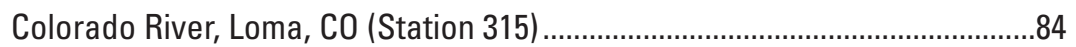

Colorado River, Gold Bar Canyon, UT (Station 316).........................................85

San Juan River, Hogback Diversion, NM (Station 317) ..................................85

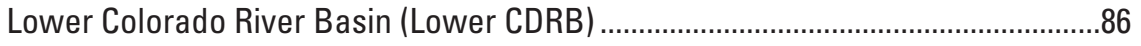

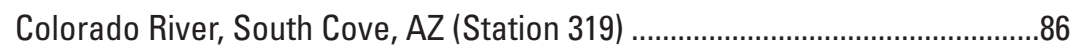

Colorado River, Willow Beach, AZ (Station 320).............................................86

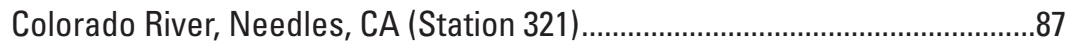

Colorado River, Imperial Dam, AZ (Station 322) ...............................................87

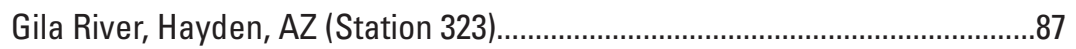

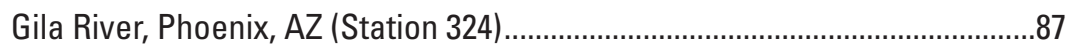

Gila River, Arlington, AZ (Station 325) .......................................................8

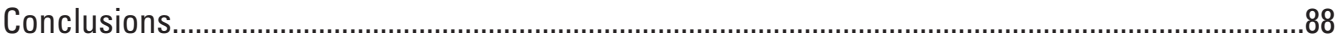

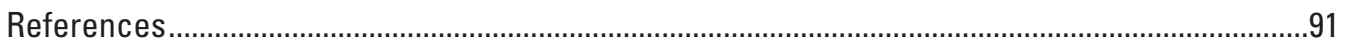

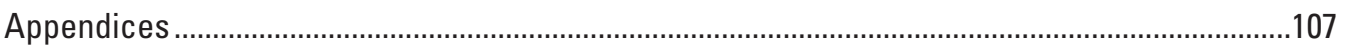

\section{Figures}

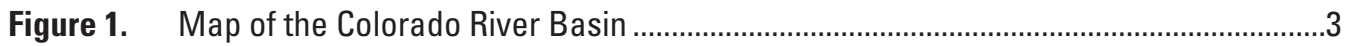

Figure 2. Map of land ownership in the Colorado River Basin ................................................6

Figure 3. Map of coal deposits and mining operations in the Colorado River Basin ...................

Figure 4. Concentrations arsenic (As) and selenium ( $\mathrm{Se}$ ) in whole-body fish composite

samples from the Colorado River Basin.................................................................28

Figure 5. Concentrations total mercury $(\mathrm{Hg})$ in whole-body fish composite samples from the Colorado River Basin

Figure 6. Concentrations cadmium $(\mathrm{Cd})$ and lead $(\mathrm{Pb})$ in whole-body fish composite samples

from the Colorado River Basin

Figure 7. Concentrations of zinc ( $\mathrm{Zn})$, copper (Cu), chromium ( $\mathrm{Cr}$ ), and nickel (Ni) in wholebody fish composite samples from the Colorado River Basin.

Figure 8. Concentrations of banned pesticides or pesticide products in whole-body fish composite samples from the Colorado River Basin

Figure 9. Unweighted geometric mean concentrations of total DDT and chlordanerelated compounds in whole-body fish composite samples from the Colorado River Basin

Figure 10. Concentrations of unlisted or restricted use pesticides or pesticide products in whole-body fish composite samples from the Colorado River Basin.

Figure 11. Concentrations of total PCBs and H4IIE bioassay-derived TCDD-EQ in wholebody fish composite samples from the Colorado River Basin.

Figure 12. Hepatic microsomal EROD activity in female and male carp, bass, and channel catfish from the Colorado River Basin

Figure 13. Mean HAl scores by lesion location in carp, bass, and channel catfish from the Colorado River Basin. 
Figure 14. Fish health indicators by station in female and male carp from the Colorado River Basin

Figure 15. Fish health indicators by station in female and male bass from the Colorado River Basin

Figure 16. Fish health indicators by station in female and male channel catfish from the Colorado River Basin.

Figure 17. Splenic macrophage aggregate parameters by station in female and male carp from the Colorado River Basin.

Figure 18. Splenic macrophage aggregate parameters by station in female and male bass from the Colorado River Basin

Figure 19. Splenic macrophage aggregate parameters by station in female and male channel catfish from the Colorado River Basin

Figure 20. Gonadal stage proportions by station in female and male carp, bass, and channel catfish from the Colorado River Basin

Figure 21. Selected gonadal histological observations in CDRB fish.

Figure 22. Reproductive health indicators by station in female carp from the Colorado River Basin

Figure 23. Reproductive health indicators by station in male carp from the Colorado River Basin

Figure 24. Reproductive health indicators by station in female bass from the Colorado River Basin

Figure 25. Reproductive health indicators by station in male bass from the Colorado River Basin

Figure 26. Reproductive health indicators by station in female channel catfish from the Colorado River Basin

Figure 27. Reproductive health indicators by station in male channel catfish from the Colorado River Basin

Figure 28. Maximum concentrations of selenium $(\mathrm{Se})$ and mercury $(\mathrm{Hg})$ in composite samples of whole fish

Figure 29. Plasma vitellogenin (vtg) concentrations in male fish and occurrence of intersex fish in the Colorado River Basin

\section{Tables}

Table 1. National Wildlife Refuges located within the Colorado River Basin ..............................5

Table 2. Stations sampled in 2003 and collection date in the Colorado River Basin..................13

Table 3. Methods incorporated into the Colorado River Basin.................................................14

Table 4. Organochlorine chemical and elemental contaminants measured in wholebody fish composite samples

Table 5. Monitoring and assessment strategy for polycyclic aromatic and polyhalogenated hydrocarbons . .17

Table 6. Number of fish collected in the Colorado River Basin .................................................23

Table 7. Lengths, weights, and age of carp collected in the Colorado River Basin...................25

Table 8. Lengths, weights, and ages of bass collected in the Colorado River Basin..................26

Table 9. Lengths, weights, and ages of channel catfish collected in the Colorado River Basin

Table 10. Percent of samples and stations that exceeded limit of detection concentrations for elemental contaminants in composite samples of whole fish from the Colorado River Basin 
Table 11. Unweighted geometric mean, minimum, and maximum concentrations of elemental contaminants in fish collected in the Colorado River Basin

Table 12. Spatial trends of chemical contaminants in fish collected in the Colorado River Basin. .32

Table 13. Unweighted geometric mean, minimum, and maximum concentrations of select elemental contaminants in fish from BEST-LRMN studies

Table 14. Percent of samples and stations with concentrations exceeding the limit of detection for organochlorine chemical residues in composite samples of whole fish in the Colorado River Basin...

Table 15. Unweighted geometric mean, minimum, and maximum concentrations of organochlorine chemical contaminants in fish from stations in the Colorado River Basin

Table 15. Unweighted geometric mean, minimum, and maximum concentrations of organochlorine chemical contaminants in fish from stations in the Colorado River Basin.

Table 16. Unweighted geometric mean, minimum, and maximum concentrations of select organochlorine chemical contaminants fish from BEST-LRMN studies.

Table 17. Geometric mean, sample size, minimum, and maximum of microsomal EROD activity in fish collected in the Colorado River Basin

Table 18. Number and location of external lesions identified on fish collected in the Colorado River Basin.

Table 19. Distribution of health assessment index scores among carp, bass, catfish, brown trout, and white sucker collected in the Colorado River Basin.

Table 20. Arithmetic mean of condition factor by species and station in carp, bass, and channel catfish collected in the Colorado River Basin

Table 21. Arithmetic mean of splenosomatic index by species and station in carp, bass, and channel catfish collected in the Colorado River Basin

Table 22. Arithmetic mean of the hepatosomatic index in bass and channel catfish collected in the Colorado River Basin

Table 23. Arithmetic mean of macrophage aggregate density, area, and percent tissue occupied in carp, bass, and channel catfish from the Colorado River Basin

Table 24. Arithmetic mean of gonadosomatic index and vitellogenin in carp, bass, and channel catfish collected in the Colorado River Basin in 2003

Table 25. Arithmetic mean of $17 \beta$-estradiol, 11-ketotestosterone, and the ratio of $17 \beta$-estradiol to 11-ketotestosterone in carp, bass, and channel catfish from the Colorado River Basin.

Table 25. Arithmetic mean of $17 \beta$-estradiol, 11-ketotestosterone, and the ratio of $17 \beta$-estradiol to 11-ketotestosterone in carp, bass, and channel catfish from the Colorado River Basin.

Table 26. Statistically significant correlations between biological and chemical endpoints in carp, bass, and channel catfish

Table 27. Summary of chemical and biological indicator results by CDRB station. 82 
Appendix 1. Selected species within the Colorado River Basin identified as

having special status by the USFWS.

Appendix 2. Results of quality assurance and limits of detection for elemental contaminants in whole-body fish composites from the Colorado River Basin .....109

Appendix 3. Results of quality assurance, method detection limit, and method quantitative limit for organochlorine compounds in whole-body fish composites from the Colorado River Basin.

Appendix 4. Lengths, weights, and ages of non-target species collected in the Colorado River Basin

Appendix 5. DDT homolog concentrations in composite samples from Stations 324 and 325

Appendix 6. Results of preliminary analysis-of-variance investigating the effects of various factors on biomarker responses in carp, bass, and channel catfish in the Colorado River Basin

Appendix 7. Fish health indicators for non-target species collected in the

\section{Conversion Factors}

\begin{tabular}{lcl}
\hline Multiply & By & To obtain \\
\hline & Length & \\
centimeter $(\mathrm{cm})$ & 0.3937 & inch (in) \\
millimeter $(\mathrm{mm})$ & 0.03937 & inch (in) \\
meter $(\mathrm{m})$ & 3.281 & foot $(\mathrm{ft})$ \\
kilometer $(\mathrm{km})$ & 0.6214 & mile $(\mathrm{mi})$ \\
\hline & Area & \\
\hline square kilometer $\left(\mathrm{km}^{2}\right)$ & 0.3861 & square mile $(\mathrm{mi})$ \\
cubic kilometer $\left(\mathrm{km}^{3}\right)$ & 0.2399 & cubic mile $\left(\mathrm{mi}^{3}\right)$ \\
\hline & Volume & \\
\hline milliliter $(\mathrm{mL})$ & 0.03381 & fluid ounce $(\mathrm{fl} . \mathrm{oz})$ \\
liter $(\mathrm{L})$ & 1.057 & quart (qt) \\
liter $(\mathrm{L})$ & 0.2642 & gallon $(\mathrm{gal})$ \\
cubic meter $\left(\mathrm{cm}{ }^{3}\right)$ & 0.0002642 & million gallons $(\mathrm{Mgal})$ \\
\hline & Mass & \\
\hline kilogram $(\mathrm{kg})$ & 2.205 & pound, avoirdupois $(\mathrm{lb})$ \\
& Concentration & \\
\hline microgram per gram $(\mu \mathrm{g} / \mathrm{g})$ & $=$ & part per million $\left(\mathrm{ppm} ; 10^{6}\right)$ \\
nanogram per gram $(\mathrm{ng} / \mathrm{g})$ & $=$ & part per billion $\left(\mathrm{ppb} ; 10^{9}\right)$ \\
picogram per gram $(\mathrm{pg} / \mathrm{g})$ & $=$ & part per trillion $\left(\mathrm{pptr} ; 10^{12}\right)$ \\
milligram per millimeter $(\mathrm{mg} / \mathrm{mL})$ & part per thousand $\left(\mathrm{ppt} ; 10^{3}\right)$ \\
milligram per liter $(\mathrm{mg} / \mathrm{L})$ & $=$ & part per million $\left(\mathrm{ppm} ; 10^{6}\right)$ \\
microgram per liter $(\mu \mathrm{g} / \mathrm{L})$ & $=$ & part per billion $\left(\mathrm{ppb} ; 10^{9}\right)$ \\
\hline
\end{tabular}

Temperature in degrees Celsius $\left({ }^{\circ} \mathrm{C}\right)$ may be converted to degrees Fahrenheit $\left({ }^{\circ} \mathrm{F}\right)$ as follows:

$$
{ }^{\circ} \mathrm{F}=\left(1.8 x^{\circ} \mathrm{C}\right)+32
$$

Temperature in degrees Fahrenheit $\left({ }^{\circ} \mathrm{F}\right)$ may be converted to degrees Celsius $\left({ }^{\circ} \mathrm{C}\right)$ as follows:

$$
{ }^{\circ} \mathrm{C}=\left({ }^{\circ} \mathrm{F}-32\right) / 1.8
$$




\title{
Biomonitoring of Environmental Status and Trends (BEST) Program: Environmental Contaminants and their Effects on Fish in the Colorado River Basin
}

\author{
Jo Ellen Hinck1, Vicki S. Blazer ${ }^{2}$, Nancy D. Denslow ${ }^{3}$, Timothy S. Gross ${ }^{4 *}$, Kathy R. Echols ${ }^{1}$, Anne P. Davis ${ }^{1 \dagger}$, Tom \\ W. May', Carl E. Orazio ${ }^{1}$, James J. Coyle ${ }^{5}$, and Donald E. Tillitt ${ }^{1}$
}

\section{Abstract}

Seven fish species were collected from 14 sites on rivers in the Colorado River Basin (CDRB) from August to October 2003. Spatial trends in the concentrations of accumulative contaminants were documented and contaminant effects on the fish were assessed. Sites were located on the mainstem of the Colorado River and on the Yampa, Green, Gunnison, San Juan, and Gila Rivers. Common carp (Cyprinus carpio), black bass (Micropterus sp.), and channel catfish (Ictalurus punctatus) were the targeted species. Fish were field-examined for external and internal anomalies, selected organs were weighed to compute somatic indices, and tissue and fluid samples were preserved for fish health and reproductive biomarker analyses. Composite samples of whole fish, grouped by species and gender, from each site were analyzed for organochlorine and elemental contaminants using performance-based and instrumental methods. 2,3,7,8-tetrachlorodibenzo-p-dioxin-like activity (TCDD-EQ) was measured using the H4IIE rat hepatoma cell bioassay. Selenium ( $\mathrm{Se}$ ) and mercury $(\mathrm{Hg})$ concentrations were elevated throughout the CDRB, and pesticides concentrations were greatest in fish from agricultural areas in the Lower Colorado River and Gila River. Selenium concentrations exceeded toxicity thresholds for fish ( $>1.0 \mu \mathrm{g} / \mathrm{g} \mathrm{ww})$ at all sites except from the Gila River at Hayden, Arizona.

\footnotetext{
${ }^{1}$ U.S. Geological Survey (USGS), Columbia Environmental Research Center (CERC), 4200 New Haven Rd., Columbia, MO 65201

${ }^{2}$ USGS Leetown Science Center, 11649 Leetown Rd., Kearneysville, WV 24530

${ }^{3}$ Center for Environmental and Human Toxicology, PO Box 110885, University of Florida, Gainesville, FL 32611

${ }^{4}$ USGS Florida Integrated Science Center, 7920 NW 71st St, Gainesville, FL 32653

${ }^{5}$ USGS, BEST Program, Fort Collins Science Center, 2150 Centre Ave., Building C, Fort Collins, CO 80526

*Current address Center for Environmental and Human Toxicology, PO Box 110885, University of Florida, Gainesville, FL 32611
}

${ }^{\dagger}$ Current address New Mexico Environment Department, 1190 St. Francis Dr., Santa Fe, NM 87502
Mercury concentrations were elevated $(>0.1 \mu \mathrm{g} / \mathrm{g} \mathrm{ww})$ in fish from the Yampa River at Lay, Colorado; the Green River at Ouray National Wildlife Refuge (NWR), Utah and San Rafael, Utah; the San Juan River at Hogback Diversion, New Mexico; and the Colorado River at Gold Bar Canyon, Utah, Needles, California, and Imperial Dam, Arizona. Concentrations of $\mathrm{p}, \mathrm{p}$ '-DDE were relatively high in fish from Arlington, Arizona $(>1.0 \mu \mathrm{g} / \mathrm{g} \mathrm{ww})$ and Phoenix, Arizona $(>0.5 \mu \mathrm{g} / \mathrm{g} \mathrm{ww})$. Concentrations of other banned pesticides including toxaphene, total chlordanes, and dieldrin were also greatest at these two sites but did not exceed toxicity thresholds. Current-use or unlisted pesticides such as dacthal, endosulfan, $\gamma-\mathrm{HCH}$, and methoxychlor were also greatest in fish from Gila River. Total polychlorinated biphenyls (PCBs; $>0.11 \mu \mathrm{g} / \mathrm{g} \mathrm{ww}$ ) and TCDDEQs ( $>5 \mathrm{pg} / \mathrm{g} \mathrm{ww}$ ) exceeded wildlife guidelines in fish from the Gila River at Phoenix, Arizona. Hepatic ethoxyresorufin $O$-deethylase (EROD) activity was also relatively high in carp from the Gila River at Phoenix, Arizona and in bass from the Green River at Ouray NWR, Utah. Altered biomarkers were noted in fish throughout the CDRB. Fish from some stations responded to chronic contaminant exposure as indicated by fish health and reproductive biomarker results. Multiple fish health indicators including altered body and organ weights and high health assessment index scores may be associated with elevated Se concentrations in fish from the Colorado River at Loma, Colorado and Needles, California. Although grossly visible external or internal lesions were found on most fish from some sites, histopathological analysis determined many of these to be inflammatory responses associated with parasites. Edema, exophthalmos, and cataracts were noted in fish from sites with elevated Se concentrations. Reproductive biomarkers including gonad development and maturation, vitellogenin concentrations, and steroid hormone concentrations were anomalous in fish from the Gila River at Hayden and Phoenix, Arizona. In addition, intersex fish were found at seven of 14 sites. The intersex condition was identified in smallmouth bass (M. dolomieu), largemouth bass (M. salmoides), channel catfish, and carp and may indicate exposure to endocrine disrupting compounds. Seven of ten male smallmouth bass from the Yampa River at Lay, Colo- 
rado were intersex. Male carp, bass, and channel catfish with low concentrations of vitellogenin were common in the CDRB. Comparatively high vitellogenin concentrations $(>0.2$ $\mathrm{mg} / \mathrm{mL}$ ) were measured in male fish from the Green River at Ouray NWR, Utah and the Colorado River at Imperial Dam, Arizona and may indicate exposure to estrogenic chemicals. Biomarker responses may be associated with industrial and municipal discharges, mining operations, irrigated agriculture, and atmospheric deposition. Continued biological monitoring is warranted to identify consistently degraded sites and those with emerging problems in the CDRB.

\section{Introduction}

The Colorado River (CDR) is the most important river of the arid southwest U.S. The CDR provides water for municipal and industrial water supplies, agriculture, hydroelectric power, and the tourism industry including sport fisheries in seven states from its headwaters in the Rocky Mountains to the Gulf of California (fig. 1). Increasing water demands and a recent drought have impacted water quality in the CDR and its major tributaries. Exploitation of natural resources, weathering of mineralized geologic formations, wastewater effluents, urban runoff, and agricultural practices have contributed to declines in water quality and have impacted habitat quality for biota in the Colorado River Basin (CDRB). As a result, many CDRB waters are listed as impaired. Multiple CDRB states have made efforts to restore native aquatic species and to characterize contaminants in CDRB waters. Elevated concentrations of metals and metalloids have been reported in water, sediment, and biota throughout the CDRB, and elevated concentrations of organochlorine pesticides such as DDT and its metabolites have been found in water, sediments, and biota in the agricultural areas of the Lower CDRB (Baker and others, 1992; Stephens and others, 1992; King and others, 1993, 1997; Abell, 1994; Bevans and others, 1996; Schmitt and others, 1999; Gebler, 2000; Spahr and others, 2000; GarcíaHernández and others, 2001, 2006; Gellenbeck and Anning, 2002). These studies have concluded that CDRB biota are at risk from exposure to elevated contaminant concentrations.

The Biomonitoring of Environmental Status and Trends (BEST) Program's Large River Monitoring Network (LRMN) studied the CDR and several of its largest tributaries from August to October 2003. The LRMN is unique among national monitoring programs with its emphasis on characterizing the effects of environmental contaminants on fish health. The LRMN accomplishes this by measuring chemical concentrations within an organism and evaluating the physiological, morphological, and histopathological responses of contaminant exposure by the organism. Our primary objective was to document the occurrence and distribution of contaminants and their effects on CDRB fish and to evaluate the potential risk from these contaminants to other wildlife. Secondary objectives were to compare biomonitoring results to other major rivers systems in the U.S. and to further refine benchmarks for quantification and interpretation of biomarker results. These latter objectives were achieved by building on the results of similar LRMN investigations in the Mississippi River Basin (MRB; Schmitt, 2002), Rio Grande Basin (RGB; Schmitt and others, 2004), Columbia River Basin (CRB; Hinck and others, 2004a), and Yukon River Basin (YRB; Hinck and others, 2004b). Contaminant concentrations in fish from our study were also compared to historical and contemporaneous CDRB data sets (Baker and others, 1992; García-Hernández and others, 2001; King and others, 1993, 1997; Schmitt and others, 1999).

Findings of the 2003 CDRB study are reported in this document. Data from this study have been incorporated into an interactive national database at: <http://www.cerc.usgs.gov/ data/best/search/index.htm>. Results from this study, together with those from other LRMN investigations, will help resource managers and scientists to assess contaminant effects on fish and wildlife and to identify CDRB areas that warrant further investigation of contaminant risks.

\section{Colorado River Basin Overview}

\section{Hydrology and Environmental Setting}

The CDR is the largest river in the southwestern U.S. and is the sixth largest river in the U.S. in terms of flow. The CDR flows 2,250 km (kilometer) through seven states, from the Rocky Mountains of Northern Colorado to the Gulf of California in Mexico (Patrick, 2000) and drains 630,000 km² (U.S. Department of the Interior (USDOI), 2001). Major tributaries include the Green, Gunnison, White, Yampa, San Juan, and Gila Rivers (fig. 1). The San Juan River converges with the CDR near Lake Powell in northern Arizona and is the largest tributary to the CDR with an annual discharge of 3.1 million $\mathrm{m}^{3}$ (Patrick, 2000). The Gila River (GR) in southern Arizona flows through arid and desert areas to connect with the CDR near Yuma, Arizona. The CDR then flows $50 \mathrm{~km}$ in Mexico although much of the water is consumed or diverted before it reaches the Gulf of California.

The CDR hydrology has been altered to accommodate water demands, control flooding, and generate hydroelectric power. The CDRB was legally divided into the Upper CDRB and Lower CDRB at Lee's Ferry upstream of the Grand Canyon by the Colorado Compact of 1922 (Brown, 1927; Patrick, 2000; Stanford and Ward, 1986; USDOI, 2001). A series of dams, reservoirs, and diversion canals were constructed to deliver water to each CDRB state, Native American Indian Tribes, and Mexico (Stanford and Ward, 1986). The compact allocated water amounts for each state in the CDRB based on estimated average flow at Lee's Ferry. Federal legislation apportioned 7.5 million acre-ft $\left(9.25\right.$ million $\left.\mathrm{m}^{3}\right)$ of water annually to each the Upper and Lower CDRB. Distribution of the annual flow in the Upper CDRB is as follows: Colorado, 


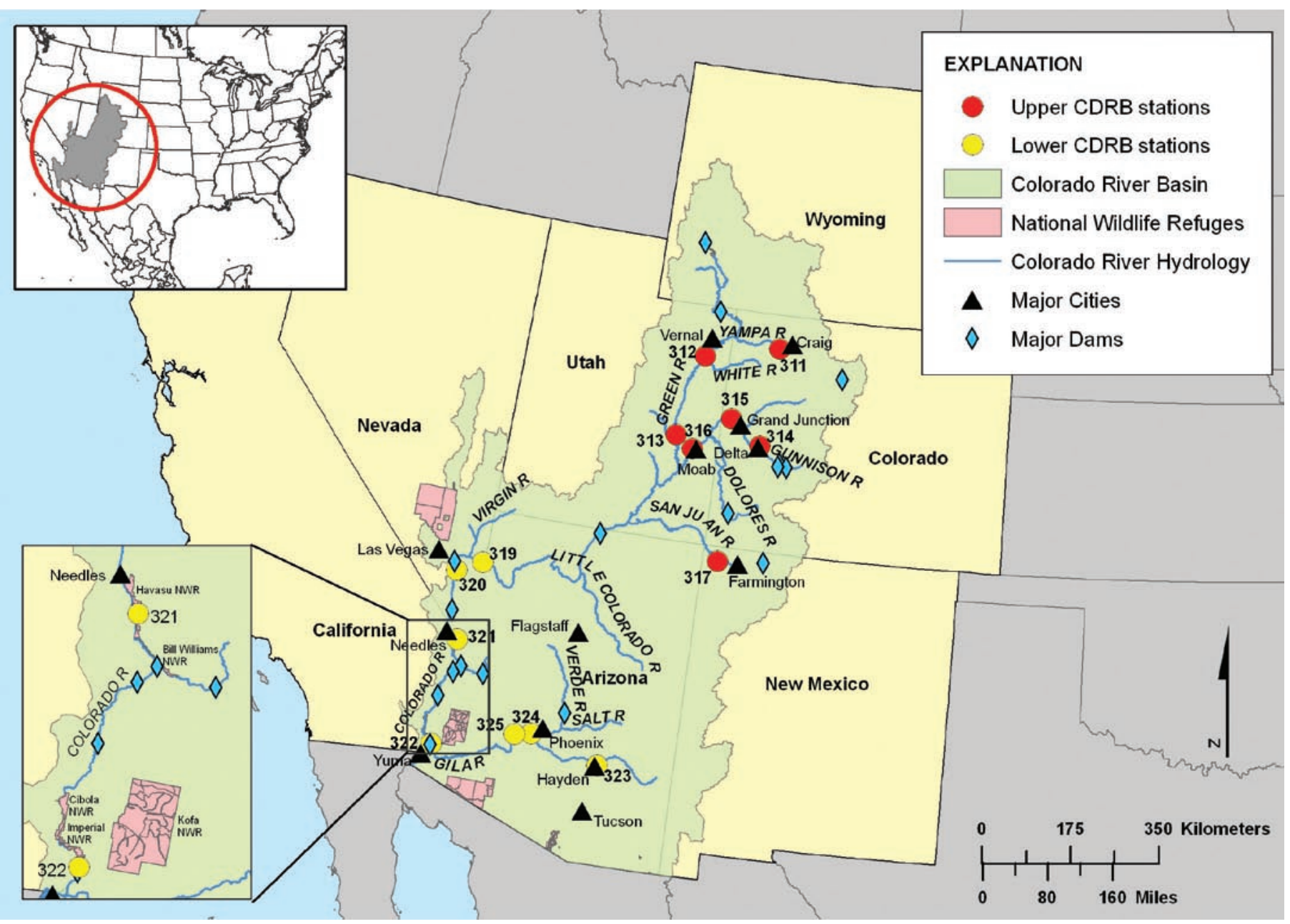

Figure 1. Map of the Colorado River Basin (CDRB) including state boundaries, cities, major rivers and tributaries, dams, National Wildlife Refuges, and sites sampled in 2003. See Table 2 for station descriptions.

51\%; New Mexico, 11\%; Utah, 23\%; Wyoming, 14\% (Patrick, 2000). Arizona, California, and Nevada receive 37\%, 59\%, and $4 \%$, respectively, of the annual flow in the Lower CDRB (Patrick, 2000). The Mexican Treaty of 1944 guarantees 1.5 million acre-ft $\left(1.85\right.$ million $\left.\mathrm{m}^{3}\right)$ of water delivered to Mexico. The flow of the CDR at Lee's Ferry was over-estimated when the allocations were calculated, and as a result, water demands will soon exceed water supplies (Spofford, 1980; Stanford and Ward, 1986).

Impoundments, channelized reaches, and irrigation diversions affect water flow in the CDRB (Gloss and others, 2005; Starnes, 1995). Annual flows from snow melt and thunderstorms fluctuated greatly before the construction of major dams and reservoirs. Today, some reaches only receive flow during the monsoon season (July-September), or flows consist entirely of irrigation return, wastewater effluent, or urban runoff (Anning, 2003; Arnold and others, 2004; Gebler, 1998; Starnes, 1995). Hydrology in the Upper CDR is characterized by rapids created from steep slopes in topography, lower sediment and dissolved-solids concentrations, and cooler temperatures (Gloss and others, 2005; Patrick, 2000; Spahr and others,
2000). The Lower CDR has reduced flow from dams and reservoirs, little slope in the topography, increased sediment load, diversions from channelization and extensive irrigation, and high evaporation rates from the arid climate. Mean monthly flows in the mainstem CDR ( $\left.>10,000 \mathrm{ft}^{3} / \mathrm{s} ;>283 \mathrm{~m}^{3} / \mathrm{s}\right)$ were greater than those from large tributaries $\left(<1,000 \mathrm{ft}^{3} / \mathrm{s} ;<28\right.$ $\mathrm{m}^{3} / \mathrm{s}$; U.S. Geological Survey (USGS), 2006). Some of the lowest flows $\left(<100 \mathrm{ft}^{3} / \mathrm{s} ;<3 \mathrm{~m}^{3} / \mathrm{s}\right.$ ) occurred in the GR (Anning, 2003; USGS, 2006). More than $40 \%$ of the CDRB annual flow derives from the Upper CDRB, where the elevation is $>3,000 \mathrm{~m}$ (Stanford and Ward, 1986) and heavy precipitation from snow and rainfall ( $>100 \mathrm{~cm}$ per year) provides $75 \%$ of the surface water. The semiarid and arid regions of the CDRB receive $<25 \mathrm{~cm}$ of precipitation annually and provide little additional flow to the mainstem river (Brown, 1927; Patrick, 2000). The amount of precipitation decreases to $<15 \mathrm{~cm}$ annually in the Lower CDRB at elevations $<1500 \mathrm{~m}$. Flow in many of the lower basin tributaries, such as the Lower GR, is slow and intermittent due to dams and diversions upstream. Tributaries in the Lower CDRB rely on infrequent rainstorms for surface water recharge. 
The CDRB has a diverse landscape that reflects the climate in the region and ranges from needleleaf forest in mountain regions to shrub and grassland in the arid desert regions. Six ecoregion divisions are found in the CDRB (USDOI, 1997). Temperate Steppe Mountains are found west of the Green River in northeastern Utah and at high altitudes in Colorado. Temperate Desert Mountains are located in south central Utah and along the Yampa River in Colorado, and Temperate Deserts characterize western Colorado and eastern Utah. Northern Arizona and southern Utah have Tropical/Subtropical Steppe, and Tropical/Subtropical Mountains are found in these same areas at higher altitudes. Most of the Lower CDRB including southern Arizona and California is Tropical/Subtropical Desert.

Climate in the Upper CDRB varies with altitude and ranges from alpine to arid conditions. The climate in the Lower CDRB is influenced by air masses from the Gulf of California, Gulf of Mexico, and the Eastern Pacific Ocean which often produce a subtropical high pressure ridge that results in low amounts of precipitation, clear skies, warm weather, and low humidity. This region is mostly arid with high rates of evapotranspiration and has little surface water recharge. Water temperature are typically $<20^{\circ} \mathrm{C}$ in the mainstem CDRB and larger tributaries, although temperature in the GR can exceed $25^{\circ} \mathrm{C}$ during the late summer and early fall (Anning, 2003; USGS, 2006).

\section{Geology}

Crystalline and sedimentary rocks and alluvium comprised of stream, landslide and glacial deposits are present in the CDRB. Formations are also of marine origin and contain sodium chloride (halite) and calcium sulfate (gypsum) salts (Moody and Mueller, 1984). The CDR is high in dissolved solids, carrying $>9$ million tons of salt downstream annually (Patrick, 2000; USDOI, 2001). Natural mineral springs, irrigation, weathering of the soils, reservoir evaporation, and municipal and industrial sources contribute to high dissolved solids in the CDRB (Patrick, 2000). Federal legislation authorized the U.S. Bureau of Reclamation, Department of Interior, and Department of Agriculture to implement cost-effective measures for managing salinity in the CDRB (Trueman, 1998). Salinity control projects include erosion control and lined irrigation ditches and sprinkler systems. Desalination plants, which have been developed to reduce salt loads, have had limited success in the Lower CDRB (Stanford and Ward, 1986).

Total dissolved solids (TDS) in the CDR and its tributaries reflect the geology of the CDRB. Weathering of the Mancos shale formation, composed of gypsum and limestone, increases dissolved mineral concentrations in CDRB waters (Moody and Mueller, 1984; Stanford and Ward, 1986; Patrick, 2000; USDOI, 2001). The Mancos formation in the Upper CDRB is extensively drained, which has increased sulfate concentrations two to four fold as water flows through the formation (Stanford and Ward, 1986). Residual soils derived from sandstone or shale are generally shallow and contain large amounts of soluble minerals including selenium (Se; Presser and others, 1994). Irrigation, natural springs, and man-made wells intercept water high in TDS associated with these formations and discharge into the CDR. As a result, TDS increase from approximately $50 \mathrm{mg} / \mathrm{L}$ at CDR headwaters to $800 \mathrm{mg} / \mathrm{L}$ at Imperial Dam (Moody and Mueller, 1984). The current TDS load is attributed to irrigation and impoundments, diversions of headwaters low in salinity, flow depletion from evapotranspiration on irrigated land, and reservoir evaporation (Gloss and others, 2005; Moody and Mueller, 1984; Stanford and Ward, 1986).

\section{Landownership and Urban Areas}

Landownership in the CDRB consists of Federal (64\%), Native American (19\%), military (2\%), and private or state lands (15\%; fig. 2). The U.S. National Park Service, U.S. Bureau of Reclamation, and U.S. Fish and Wildlife Service (USFWS) own much of the land along the CDR and its major tributaries. Many of these areas are designated as national parks, monuments, and recreation areas. Private lands used for grazing and agriculture are typically located within the flood plains of these rivers. Large Native American reservations in the CDRB include the Unitah and Ouray Tribes along the Green River, the Southern Ute Tribe and Navajo Nation along the San Juan River, the Hualapai and Havasupai Tribes along the Grand Canyon, Fort Apache and San Carlos Apache Tribes in the Upper GR, and the Colorado Indian Tribe along the Lower CDR. Large military facilities include the Barry M. Goldwater Air Force Range, the Yuma Marine Corps Air Station, and the Yuma Proving Ground in the Lower CDRB. Land use in the CDRB has changed in the past 50 years with decreases in forests and pastures and increases in cropland, highways, airports, roads, wilderness areas and parks, and industrial and urban areas (O’Donnell, 1997).

Threatened and Endangered species are found on Federal lands of the CDRB (Appendix 1). Several areas have been designated National Wildlife Refuges (NWRs) that provide important nesting habitat for waterfowl and wintering areas and stopover points for migratory birds (table 1; fig. 1). Several regional conservation programs have been established to monitor and protect endangered large river fishes [bonytail chub (Gila elegans), humpback chub (G. cypha), razorback sucker (Xyrauchen texanus), and Colorado pikeminnow (Ptychocheilus lucius)] in CDRB waterways designated as critical habitat (Holden, 2000; Lower Colorado River MultiSpecies Conservation Program, 2005; Upper Colorado River Endangered Fish Recovery Program (UFRP), 2005). Recovery strategies include raising endangered fish in hatcheries for stocking, managing non-native fish, improving river habitat, and conducting research (Hamilton and others, 2005a; UFRP, 2005).

The CDRB is sparsely populated due to climate and topography, but population centers are growing at a rapid pace. The two largest urban areas are Phoenix, Arizona and 
Table 1. Sampling stations located within approximately $75 \mathrm{~km}$ of a National Wildlife Refuge (NWR) in the Colorado River Basin.

\begin{tabular}{ll}
\hline \multicolumn{1}{c}{ CDRB station } & \multicolumn{1}{c}{ NWR name } \\
\hline Lay, CO (311) & Browns Park \\
Ouray NWR, UT (312) & Ouray \\
Willow Beach, AZ (320) & Desert \\
Needles, CA (321) & Bill Williams River, Havasu \\
Imperial Dam, AZ (322) & Cibola, Imperial, Kofa \\
\hline
\end{tabular}

Las Vegas, Nevada. Phoenix, the sixth largest city in the U.S., has a population $>1,300,000$ (Perry and Mackun, 2001). Las Vegas, one of the fastest growing metropolitan areas from 1990 to 2000, has a population $>1,500,000$. Other cities in the basin with populations $>100,000$ include Tucson and Yuma, Arizona. The population in the CDRB increased $>13 \%$ from 1990 to 2000 and populations growth has increased $>50 \%$ in some areas in western Colorado, southern Nevada, southwestern Utah, and northwestern Arizona (Perry and Mackun, 2001). In addition, resort mountain communities have been steadily growing at a rate of $10 \%$ a year. As the CDRB population continues to grow, demands on water and other natural resources will increase.

\section{Dams}

The CDR is one of the most highly regulated river systems in the world. Multiple dams have been built for agricultural irrigation, hydroelectric power generation, river regulation and flood control, recreation, municipal and industrial supplies, and wastewater disposal (fig. 1; Gloss and others, 2005; Paulson and Baker, 1983; USDOI, 1997). More than 117 reservoirs have been created (Stanford and Ward, 1986). The dams and reservoirs have altered the ecological, morphological, and hydrological characteristics of the CDR. Effects of regulation include changes in water temperature, turbidity, water chemistry, aquatic habitat, disruption of fish migration and spawning, increased predation and competition by non-native species, and extinction of native species (Gloss and others, 2005; Holden, 1979; Holden and Stalnaker, 1975; Minckley, 1991; Standford and Ward, 1986).

Lake Mead, the nation's largest reservoir, extends from the mouth of the Grand Canyon at South Cove to the Black Canyon at Hoover Dam. Hoover Dam is used to generate hydroelectric power for Nevada, Arizona, and California (Harbeck and others, 1958; Paulson and Baker, 1983). Approximately $90 \%$ of Lake Mead's 28 million acre-feet (34.5 million $\mathrm{m}^{3}$ ) volume is from the CDR (Paulson and Baker, 1983), and Lake Mead supplies most of the water storage and regulation for the Lower CDRB (Patrick, 2000). Glen Canyon Dam, the only major dam located on the CDR mainstem in the Upper CDRB, forms Lake Powell and controls most of the water from the Upper CDRB (Patrick, 2000). The Davis Dam which forms Lake Mohave and Parker Dam which creates Lake Havasu are major municipal diversions of the Colorado River Aqueduct and Central Arizona Project, respectively. Other important dams in the CDRB include the Navajo Dam on the San Juan River, and the Headgate Rock, Palo Verde Diversion, and Imperial Dams located on the Lower CDR. The Morelos Dam, located south of the Northerly International Boundary with Mexico, is a diversion dam that assists in rerouting water to Mexico via the Alamo Canal (Patrick, 2000; USDOI, 1997). Construction of dams has diverted most of water for irrigation and has severely reduced the large riparian and wetlands areas in the Colorado River Delta Region in Mexico (Mora and others, 2003). As a result, important habitat for endangered species and migratory birds has been lost.

\section{Water Quality Impairments and Fish Consumption Advisories}

Impairments are issued for rivers, streams, and lakes that do not meet state defined water quality standards as required by Section 303(d) of the Clean Water Act. Many CDRB water bodies are listed as impaired for turbidity, TDS, fecal coliform, temperature, metals, and pesticides. The review of 303(d) listed waters for this report focused only on those associated with rivers and reservoirs related to the CDR and its major tributaries.

Impairments in the Green River Basin were primarily in small streams, and common impairments included fecal coliform, TDS, and temperature (Utah Department of Environmental Quality (UDEQ), 2000; Wyoming Department of Environmental Quality (WDEQ), 2002). Impairments for TDS and chlorine were identified for the Lower Green River (WDEQ, 2002). Impairments for copper (Cu), silver (Ag), and cadmium $(\mathrm{Cd})$ were associated with the Ferris-Haggarty Mine located on Haggarty Creek in the Little Snake River Basin of the Upper CDRB (WDEQ, 2002). A Se impairment for Ashley Creek is associated with irrigation flow to the Stewart Lake Management Area in Utah (UDEQ, 2000). In Colorado, $\mathrm{Cd}, \mathrm{Cu}$, lead $(\mathrm{Pb})$, manganese $(\mathrm{Mn})$, zinc $(\mathrm{Zn})$, and iron $(\mathrm{Fe})$ impairments in rivers are associated with mining activities (Colorado Department of Public Health and Environment (CDPHE), 1998). The entire length of the Eagle River, a tributary of the CDR in Colorado, is listed as impaired for $\mathrm{Cd}, \mathrm{Mn}$, and $\mathrm{Zn}$ from Eagle Mine (CDPHE, 1998). Streams in the Gunnison and Lower Dolores River Basins have impairments for Se and ammonia, and $\mathrm{Cd}, \mathrm{Mn}$, and $\mathrm{Zn}$ impairments have been issued near the historical mining area of Idarado (CDPHE, 1998). The Upper Animas River in the San Juan River Basin (SJB) has aluminum (Al), Cd, Cu, Fe, $\mathrm{Pb}$, and $\mathrm{Zn}$ impairments associated with abandoned mines in the San Juan Mountains, and impairments in the Lower SJB are primarily for stream bottom deposits possibly from agriculture, erosion, or urban runoff (New Mexico Environment Department (NMED), 2000). 


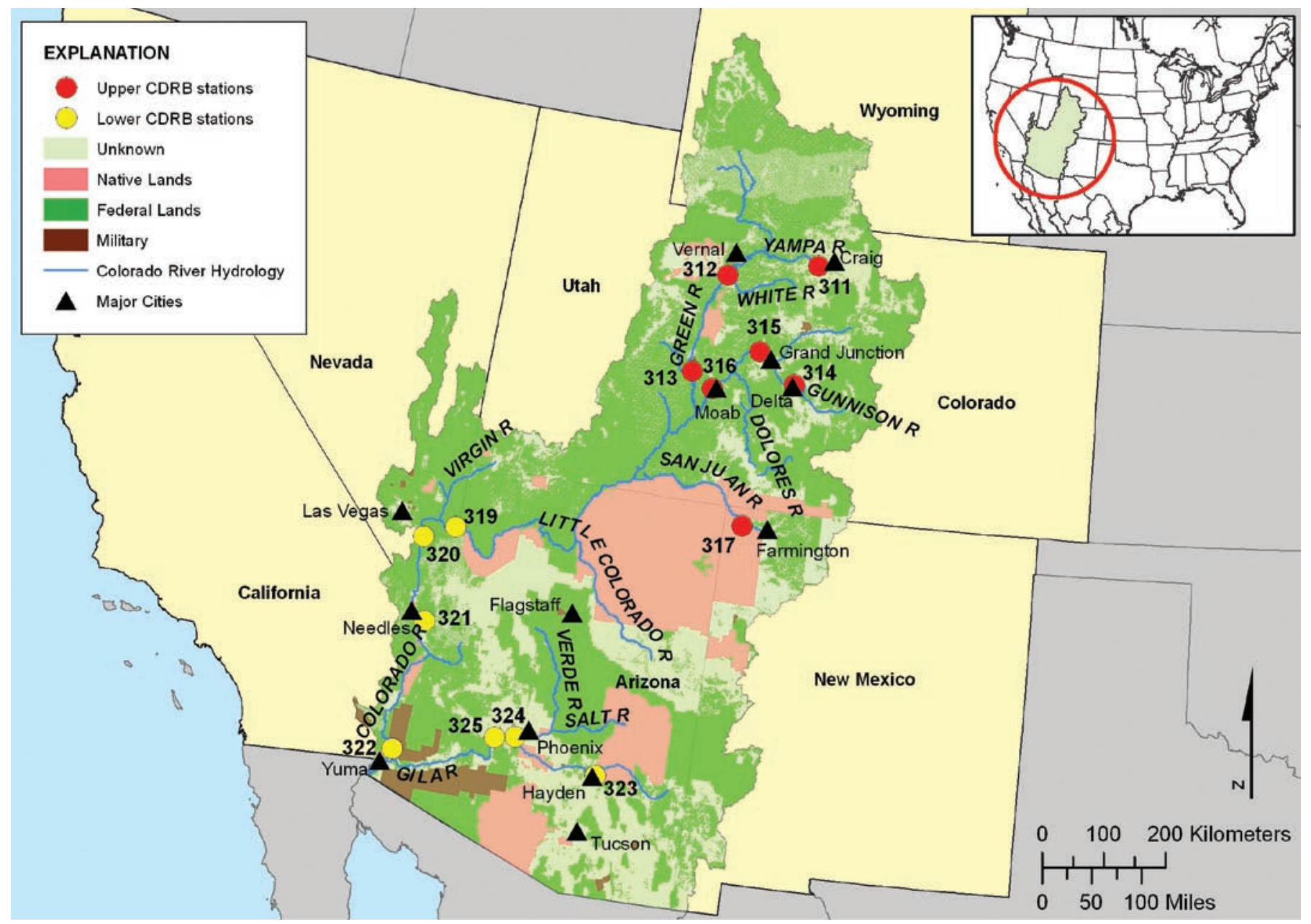

Figure 2. Map of land ownership in the Colorado River Basin (CDRB) including government and private lands and sites sampled in 2003.

Most water quality impairments in the Lower CDRB are associated with metropolitan areas and agricultural practices rather than mining. Rivers near Las Vegas have impairments for Fe, boron (B), phosphorus (P), and temperature (Nevada Division of Environmental Protection, 2002). The Imperial Valley of California, which uses the Lower CDR for irrigation, has impairments for siltation, pesticides, and Se associated with agricultural return flows (California Environmental Protection Agency (CEPA), 2003). Most impairments in streams and rivers in the Upper GRB, including turbidity, conductivity, and metals $(\mathrm{Al}, \mathrm{Cu}, \mathrm{Cd}, \mathrm{Pb}$, and $\mathrm{Zn})$ are associated with agriculture, erosion, and resource extraction (Arizona Department of Environmental Quality (ADEQ), 2004; NMED, 2000). Turbidity and fecal coliform impairments have also been issued for many tributaries in the Lower GRB, and impairments for $\mathrm{Cu}$ and $\mathrm{Zn}$ are likely from extensive mining in the region.

Fish consumption advisories are designed to protect human health and are also good indicators of water quality because most are issued after assessing contaminant concentrations in fish tissue. More than 50 fish consumption advisories have been issued for reservoirs and rivers in the
CDRB (USEPA, 2004a). Advisories for mercury (Hg), DDT, dieldrin, chlordane, and toxaphene were the most common.

Fish consumption advisories have not been issued for the mainstem of the CDR. A Se advisory for all freshwater fish located from the confluence of Ashley Creek with the Green River to the Lake Stewart Wildlife Management area did not extend into the mainstem of the Green River (USEPA, 2004a). Lake Stewart was studied extensively after Se contaminated the area and negatively impacted wildlife (Stephens and others, 1992). A Hg advisory for the consumption of common carp (Cyprinus carpio) and channel catfish (Ictalurus punctatus) was issued on the San Juan River from the Hammond Diversion to the mouth of the Mancos River (USEPA, 2004a). Potential $\mathrm{Hg}$ sources in the area include two coal-fired power plants, the San Juan Power Plant and the Four Corners Power Plant (Abell, 1994). Multiple consumption advisories in the GRB have been associated with historic use of banned pesticides. Consumption advisories for chlordane, $p, p$ '-DDD, $p, p^{\prime}$-DDE, $p, p$ '-DDT, dieldrin, and toxaphene were issued for all fish in the Hassayampa River from the lower portion of Buckeye Canal to the GR (USEPA, 2004a). In addition, the Salt River west of $59^{\text {th }}$ Avenue in Phoenix to the GR and the 
GR from it's confluence with the Salt River to near Gila Bend, Arizona have $p, p$ '-DDT, dieldrin, chlordane, and toxaphene advisories for all fish (USEPA, 2004a).

Reservoirs have more fish consumption advisories than rivers in the CDRB. Sweitzer Reservoir, constructed on the alluvial plain of the Gunnison and Uncompahgre Rivers in Colorado, has a Se advisory for all fish (USEPA, 2004a). Selenium has leached from underlying shales. Stewart Lake Management Area near Vernal, Utah also has a Se advisory for all fish due to contaminated irrigation water (USEPA, 2004a). Waters from this area flow into the Green River. The Navajo Reservoir on the San Juan and Piedra Rivers and the McPhee Reservoir along the Dolores River and nearby Narraguinnep Reservoir have $\mathrm{Hg}$ advisories for multiple sport fish including largemouth bass (Micropterus salmoides), smallmouth bass (M. dolomieu), channel catfish, black crappie (Pomoxia nigromaculatus), yellow perch (Perca flavescens), rainbow trout (Oncorhynchus mykiss), kokanee salmon (O. nerka), northern pike (Esox lucius), and walleye (Stizostedion vitreum; USEPA, 2004a). The Hg source in these reservoirs has been attributed to mining and atmospheric deposition from coal-fired power plants in the area (Abell, 1994; Melancon and others, 1979). Nearby Lake Farmington in New Mexico also has Hg advisories issued for largemouth bass and channel catfish, and Bear Canyon Reservoir in the Upper GRB has $\mathrm{Hg}$ advisories for largemouth bass, channel catfish, white crappie ( $P$. annularis), and bluegill (Lepomis macrochirus; USEPA, 2004a). Several lakes in southern Arizona including Alamo Lake on the Bill Williams River have $\mathrm{Hg}$ advisories for sport fish, and potential $\mathrm{Hg}$ sources include historic ore milling and amalgamation processes, naturally mineralized soils, and atmospheric deposition (USEPA, 2004a).

\section{Major Sources of Contaminants to the Colorado River Basin}

The CDRB is generally arid and highly mineralized, and petroleum-rich geologic formations underlay much of the basin. These conditions allow salts, oil, and trace elements such as As, Se, and heavy metals to be available for potential release into the environment through natural weathering and resource extraction. Irrigation and mining occur throughout the CDRB and accelerate the rates of the processes controlling the release and distribution of these naturally occurring compounds (Schmitt, 1998). Therefore, elevated concentrations of contaminants in CDRB tributaries result from agriculture, mining, and energy-related activities and from the populations they support. Dams and diversions alter the flux of water and sediment and their associated contaminants, and irrigation practices leach contaminants from underlying soil and rock formations.

\section{Agriculture}

Historically, sediment transported from the Upper CDRB created marshlands and fertile floodplains in the Lower CDRB during the monsoon season (Minckley, 1991; Mueller and Marsh, 2002). Crops flourished and diverse wildlife communities were supported (Mueller and Marsh, 2002). Today, agriculture in the Lower CDRB is important for the economies of California and Arizona. Most farms are located in the GRB in southern Arizona and the Imperial Valley in southern California which have mild climates and fertile soils. Major crops include cotton, wheat, alfalfa, and vegetables, including broccoli, carrots, and lettuce, and farms in the region have some of the highest yields per acre in the U.S. (USDOI, 1997). Agriculture is more limited in the Upper CDRB, although hay, corn, small grains, dry beans, onions, melons, fruit, and grapes are important in some areas (Spahr and others, 2000). Agricultural demands and low annual precipitation have led to extensive irrigation systems throughout the CDRB. Nearly four million acres of farmland are irrigated in the CDRB (USDOI, 2001). Some counties in southern Arizona and California rely on water from irrigation canals for their crops. Pesticide applications in this area are high. Active ingredients in larger applications (>1,100 kg or 9,500 liters per acre) included atrazine, 1,3 dichloropropene, metam-sodium, trifluralin, chloropicrin, aldicarb, S-Ethyl dipropylthiocarbamate, benefin, bensulate, dimethyl tetrachloroterephthalate, and pronamide in 2002 (ADEQ, 2002). Total pesticides applied to Arizona soils in 1988 exceeded $816,500 \mathrm{~kg}$ with most (56\%) being insecticides (Artiola and Dubois, 1995). Wildlife in these areas may have been exposed to various chemicals including arsenic-based defoliants, stable organic herbicides and insecticides, metals, and salts (Aritola and Dubois, 1995). DDT and toxaphene remain present in GRB soils and sediments including those in the Phoenix metropolitan area (ADEQ, 1992). Many contaminants such as $p, p^{\prime}$-DDE and Se are also a concern in the Mexicali Valley of the CDR delta (García-Hernández and others, 2001, 2006; Mora and others, 2003).

\section{Mining and Extractive Industries}

Oil and natural gas extraction and mining provide a substantial proportion of several state economies in the CDRB, but exploitation of these natural resources have negatively affected aquatic habitat and biota. Abandoned and active mines eliminated $>19 \mathrm{~km}$ of fisheries in the Upper CDRB (Abell, 1994). One of the most heavily polluted areas is the Animas River where surface water was severely polluted by abandoned mine runoff near Silverton, Colorado, in the San Juan Mountains (Abell, 1994). Minerals such as $\mathrm{Cu}$, gold (Au), Ag, Pb, and $\mathrm{Zn}$ have been heavily mined throughout the CDRB (fig. 3). Major oil and natural gas deposits occur in the Upper CDRB from northwestern New Mexico to Wyoming. Oil shale and tar sands located in the Upper Green River Basin are not considered major commercial deposits (USDOI, 1997). 


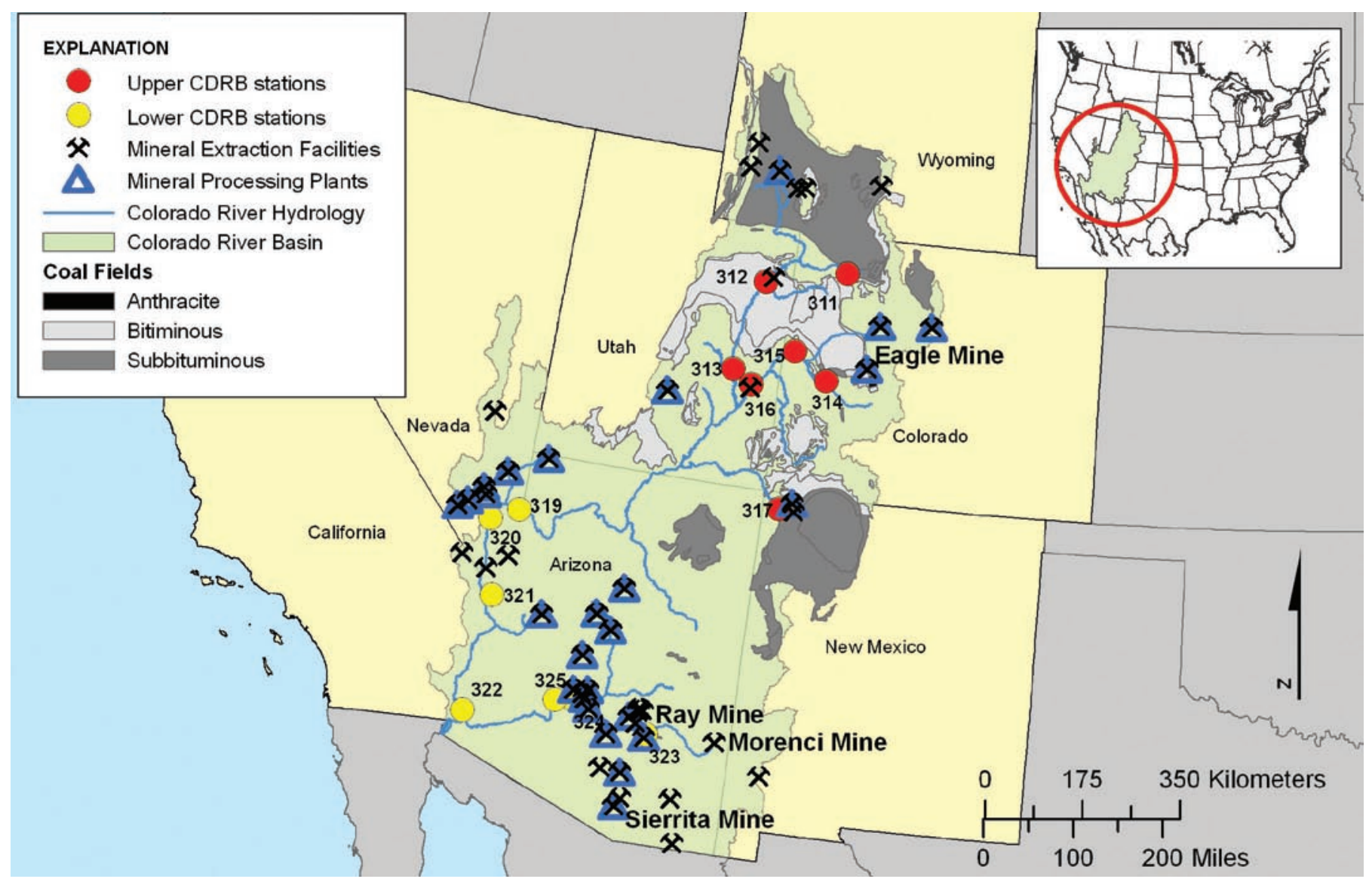

Figure 3. Map of coal deposits and mining operations in the Colorado River Basin (CDRB). Mineral extraction facilities include ferrous and nonferrous mines and construction and agricultural mineral operations. Ferrous mineral and nonferrous metal processing plants are also shown.

Coal mining in Colorado, Utah, and New Mexico has grown in the past several decades, and a large uranium deposit occurs in southeastern Utah and western Colorado.

Copper is used for electrical and electronic products, industrial machinery and equipment, building construction, and transportation equipment. Copper deposits in Arizona have been exploited, and mining districts in Arizona produce $67 \%$ of the U.S. supply (Niemuth, 2004). The Morenci, Ray, and Sierrita mines in the GRB and the Bagdad mine in west central Arizona produce $>90 \%(635,000 \mathrm{~kg})$ of the copper in Arizona (fig. 3). Additional copper mines in Arizona are being considered. Utah and New Mexico are ranked second and third in U.S. copper production. Copper mining operations are also found in the Upper GRB in southwest New Mexico (Kramer and others, 1997; New Mexico Energy, Minerals, and Natural Resources Department (NMRD), 2003). Although emissions are monitored, contaminants from 15 copper smelters in Arizona and New Mexico are a growing concern in the region. Smelters are point sources for sulfur oxides, toxic metals (for example, $\mathrm{As}, \mathrm{Pb}, \mathrm{Hg}$ ), fine particulates, and acid precipitation and can contaminate surrounding areas (World Bank Group, 1998). Biota near Hayden, Arizona, where a copper smelter is in operation, may be at risk (Arizona Department of Health Services, 2002; King and Baker, 1995). The Hayden smelter is located directly on the GR, one of the principal sources of irrigation water for southern Arizona (USEPA, 1977). In the 1970s, biota including algae, caddis fly and black fly larvae, and fish were absent below the Hayden smelter (USEPA, 1977). Runoff from storm events, erosion of mine tailings, and emissions from the smelters may adversely impact threatened and endangered species in this area (G. Beatty, oral communication). Other mineral deposits in the CDRB include $\mathrm{Au}, \mathrm{Ag}, \mathrm{Pb}$, and $\mathrm{Zn}$ in the Uncompahgre and San Juan Mountains in southwestern Colorado (Colorado Mining Association (CMA), 2004). These metals are also mined in the Green River and Colorado River placers in Utah although they do not produce a significant amount of ore. Rising gold prices and funding availability have renewed interest in precious metal exploration in southern Arizona (Niemuth, 2004).

One of the largest U.S. natural gas deposits is located in the SJB, resulting in New Mexico being a major U.S. natural gas producer (NMRD, 2003). Smaller deposits in northeastern Utah and northwestern Colorado are associated with coalbeds. A portion of the natural gas in New Mexico is coalbed methane (CBM) in which New Mexico ranks first in U.S. production and reserves (NMRD, 2003). The Fruitland Coal formation in the SJB is the largest CBM producer in the 
U.S. Natural gas extraction and processing have been associated with PAH contamination that can affect water quality (Abell, 1994). Several large surface coal mines including the San Juan, Navajo, and La Plata are also active in the SJB and produce bituminous coal for electrical power. Two coalfired power plants, the San Juan and Four Corners, located west of Farmington, New Mexico, may contaminate the San Juan River with trace elements and PAHs through wet or dry deposition (Abell, 1994; NMRD, 2003). Gernard and others (1983) suggested that the $\mathrm{Cd}$ and $\mathrm{Hg}$ from power plant effluent pose the largest threat to aquatic ecosystems, but Se has also been measured at high concentrations in power plant disposal waters. Colorado and Utah have active coal mines, both surface and underground, that excavate bituminous coal for electricity production (Bon and Wakefield, 1999; CMA, 2004). Coal mining operations can contaminate surface water by increasing sediment load and TDS concentrations, increasing erosion from strip mining, and altering $\mathrm{pH}$, which may enhance the transport of other trace elements (Abell, 1994). Acid deposition from coal-fired power plants in the Yampa River Basin near Craig and Hayden, Colorado have caused reproduction problems in amphibians in nearby waters, and problems may persist if emissions remain high (Turk and Campbell, 1997).

Other non-metallic mineral deposits with the potential to affect water quality in the CDRB include gypsum, sulfur, fluorospar, barite, and asbestos. The Henderson mill located in Grand County, Colorado, processes molybdenum to make alloy steels, stainless steel, and cast iron and is the largest molybdenum mine in the world (CMA, 2004). Large uranium deposits are located in Colorado, Utah, and New Mexico although significant production is limited to the Colorado Plateau in western Colorado and southeastern Utah (Bon and Wakefield, 1999; CMA, 2004; NMRD, 2003). Uranium mine and mill tailings may also contain large quantities of TDS, Se, molybdenum, and vanadium as well as radioactive materials (Abell, 1994). One of the largest uranium mining operations near Moab, Utah ceased production in 1984, but the mill tailings site is still located nearby. The unlined tailings site, located along the CDR, covers more than 53 hectares and leaches radioactive wastes and ammonia into the CDR near potential habitat for endangered aquatic species (Fairchild and others, 2002). Radioactive isotopes released from the site can be transported downstream towards Lake Mead by sediment and water, and groundwater used for irrigation and drinking water is also at risk to become contaminated. Consequently, the U.S. Department of Energy will remove 11.9 million tons of radioactive tailings from the banks of the CDR (U.S. Department of Energy, 2005). A study at the uranium mine on the Animas River at Durango, Colorado found bottom fauna and invertebrate populations were eliminated from mill wastes for $48 \mathrm{~km}$ downstream of the site, but radioactive chemical concentrations declined after the mill closed in 1963 (Anderson and others, 1963).

\section{Industrial and Municipal Sources}

Heavy demands have been placed on the CDR to meet municipal supply and wastewater disposal needs of large population centers. The CDRB provides municipal and industrial water to over 27 million people (USDOI, 2001). Much of the CDRB is sparsely populated with many towns and cities located along river corridors. Main population centers including Las Vegas, Nevada and Phoenix and Yuma, Arizona are located in the Lower CDRB, which already has a limited water supply due to recent drought conditions, heavy irrigation, and mandated state water allocations. Such demands on the water supply result in ephemeral flows in many streams and rivers. Las Vegas uses the CDR at Lake Mead as its major water resource, but the city obtains $10 \%$ of its water from groundwater. The CDR is also the primary source of drinking water in Yuma. In the early 1970s, the Central Arizona Project (CAP) was initiated to divert water via a concrete aqueduct from the CDR at Lake Havasu to Phoenix and Tucson. The surface water from CAP and the Verde and Salt Rivers provide $95 \%$ of the water to Phoenix. Flows in the GRB consist primarily of irrigation return water, storm water, and effluent from wastewater treatment plants (Anning, 2003; Cordy and others, 1998; Gebler, 1998). Effluents from seven wastewater treatment plants dominate the water in the GR from its confluence with the Salt River at Phoenix to Gillespie Dam (Cordy and others, 1998). Several studies concluded that chemicals in wastewater effluent from the Las Vegas and Phoenix areas may negatively impact aquatic wildlife (Arnold and others, 2004; Bevans and others, 1996; Gross and others, 2004; Patiño and others, 2003 b); therefore, water quality from municipal wastewater is a concern in these areas.

Federal law requires that permits be issued for companies to discharge wastewater into rivers. Industries that manufacture, process, or use toxic chemicals are required to annually report releases of these chemicals. There is little industrial development and associated industrial permitted discharges to the CDR or its tributaries; most are near Las Vegas and Phoenix. Most permitted point sources are municipal wastewater treatment facilities, and discharges include biological oxygen demand (BOD) and TDS (USEPA, 2004b). The Phoenix area has multiple wastewater treatment facilities that discharge inorganic compounds ( $\mathrm{Se}, \mathrm{As}, \mathrm{Zn}, \mathrm{Cr}, \mathrm{Cu}, \mathrm{Mn}$, and $\mathrm{Hg}$ ) into the Salt River and GR, and an aerospace manufacturer discharges $\mathrm{Pb}, \mathrm{Ag}$, and $\mathrm{Cu}$ into the Salt River. Permitted discharges from the Las Vegas area were limited to BOD and TDS from a wastewater treatment facility (USEPA, 2004b). Power plants and mining industries reported most of the 2002 toxic releases (non-permit releases) into the CDRB (USEPA, 2004e). Releases from power plants were mostly dioxins and dioxin-like compounds and were generally <500 g. Mining operations in Colorado and Arizona commonly reported small releases of $\mathrm{Cu}$ and $\mathrm{Mn}$. The San Juan Coal Company (San Juan Mine) reported one time releases $(>5,000 \mathrm{~kg}$ ) of antimony ( $\mathrm{Sb}), \mathrm{As}$, barium $(\mathrm{Ba}), \mathrm{Cr}$, and $\mathrm{Cu}$, but no other large releases were reported in the CDRB. Areas with large 
quantities of air emissions include Phoenix, Las Vegas, Grand Junction, and near Farmington. The most common compound released into the air from fugitive and point source emissions were sulfuric acid, hydrochloric acid, hydrogen fluoride, ammonia, $\mathrm{Pb}$, styrene, and $\mathrm{Cu}$ (USEPA, 2004e). The amount of unreported contaminant releases in the CDRB is unknown.

Several CDRB locations are designated as Superfund sites (USEPA, 2004c). A zinc mine and a uranium and vanadium processing plant in the Upper CDRB are associated with mine and mill tailings; $\mathrm{As}, \mathrm{Cd}, \mathrm{Cr}, \mathrm{Cu}, \mathrm{Pb}, \mathrm{Hg}, \mathrm{Zn}$, polychlorinated biphenyls (PCBs), uranium, radium, and vanadium have contaminated surface water, groundwater, and soils near these sites. The Monticello uranium mill in Utah is listed for radioactive materials (radium, uranium, and vanadium) and some metals ( $\mathrm{As}, \mathrm{Cd}, \mathrm{Cr}, \mathrm{Cu}, \mathrm{Pb}, \mathrm{Se}$, and $\mathrm{Zn}$ ) in the surface water and groundwater. The United Nuclear Corporation near Gallup, New Mexico in the SJB began mining uranium in the late 1960s and operating a mill in 1977, and contaminants from tailing fluids containing As, Cd, Cobalt (Co), Nickel $(\mathrm{Ni})$, and Se were released after a dam broke and infiltrated the alluvial aquifers near the mill (USEPA, 2004c). A landfill near Farmington, New Mexico in the SJB has been associated with groundwater contamination by $\mathrm{Mn}$ and volatile organic compounds. Superfund sites in Arizona are located in the GRB and associated with groundwater and soil contamination (USEPA, 2004c). Most facilities were landfills, airports, and military operations near Phoenix and Yuma, and common contaminants included volatile organic compounds, $\mathrm{Cr}$, As, $\mathrm{Cd}, \mathrm{Cu}$, petroleum hydrocarbons, PAHs, pesticides, and nitroaromatics.

\section{Perchlorate}

Perchlorate is associated with releases of ammonium perchlorate by military operations, aerospace programs, and defense contractors and has been measured in surface and groundwater in Arizona, Nevada, and California (Urbansky, 2002). Manufacturing facilities near Henderson, Nevada in the Las Vegas Valley, currently owned by the Kerr-McGee Corporation, are the primary source of perchlorate in the Lower CDR (Owens and others, 2004). The aquifer located beneath the facility was contaminated with perchlorate that leached from unlined evaporation ponds. As a result, significant amounts of perchlorate, as much as $408 \mathrm{~kg} /$ day (900 lbs/ day), entered the Las Vegas Wash in the late 1990s (USEPA, 2004d). Kerr-McGee, in conjunction with the Nevada Division of Environmental Protection and the USEPA, initiated a control strategy to capture and treat the perchlorate in 1997 after the facility was identified as the source of contamination. Perchlorate concentrations in the surface water in Las Vegas Bay, Lake Mead, and the Lower CDR have declined since 1999, although decreased dilution of the contaminated water in Lake Mead is likely if recent drought conditions persist (USEPA, 2004d). Perchlorate contamination is also being monitored in Arizona. Concentrations in the Lower CDR are attributed to the Henderson facility although other facilities including military areas near Yuma and manufacturing plants in Phoenix have introduced perchlorate to the GRB (Owens and others, 2004).

Perchlorate can disrupt thyroid function by interfering with iodide accumulation, which blocks hormone production (Urbansky, 2002; Wolff, 1998). Thyroid-related studies in mammals (National Research Council, 2005), fish (Brown and others, 2004a; Mukhi and others, 2005; Patiño and others, 2003a), and amphibians (Goleman and others, 2002) indicate that further research is needed to characterize the potential deleterious effects of perchlorate.

\section{Extant Sources of Information on Contaminants in the Colorado River Basin}

Water quality in the CDRB has been studied due to concerns for threatened and endangered species, elevated Se concentrations in irrigation return flows, and decreasing water availability. Regional-scale contaminant studies in the CDRB are limited. The CDR drains an extensive landscape, and many water quality studies have focused on particular areas or regions within the basin. Several large Federal programs including the National Contaminant Biomonitoring Program (NCBP), the National Water Quality Assessment (NAWQA) Program, and the National Irrigation Water Quality Program (NIWQP) have conducted contaminant studies in various regions of the CDRB. The USFWS has also conducted multiple contaminant studies in the basin.

The main objective of the NCBP was to document temporal and spatial trends of organochlorine and inorganic concentrations in fish (Schmitt and others, 1999). The program reported concentrations of many persistent contaminants such as organochlorine pesticides, PCBs, and Hg were decreasing in whole-body fish samples from 107 locations across the U.S. by the mid-1980s. Historical NCBP concentration data from 1970 to 1986 are available for fish including carp, bass (Micropterus sp.), and channel catfish from seven locations (Lake Powell and Lake Mead; San Carlos Reservoir; Lake Martinez; Lake Havasu; Yuma, Arizona; and Vernal, Utah) in the CDRB (Schmitt and others, 1999). The fourth highest mean Cd concentration in the U.S. $(>0.05 \mu \mathrm{g} / \mathrm{g}$ ) was in fish from Vernal. Mining activities in Colorado and Utah are likely sources of Cd in this area (May and McKinney, 1981). Mean concentrations of arsenic (As) in fish from Lake Havasu and Yuma were high $(>0.2 \mu \mathrm{g} / \mathrm{g})$ and could be from arsenical agricultural chemicals in intensively farmed regions of the Lower CDRB (Schmitt and others, 1999). The highest mean Se concentrations $(>1.0 \mu \mathrm{g} / \mathrm{g})$ reported by the NCBP were in fish from the CDRB, and these concentrations could be a threat to piscivorous wildlife (Schmitt and others, 1999). Conversely, organochlorine pesticides were generally low in the CDRB, although high concentrations of total DDT $(>0.75 \mu \mathrm{g} / \mathrm{g})$ were documented in agricultural areas of the Lower CDRB. 
The NAWQA Program of the USGS examines water quality in river basins and groundwater systems in the U.S. Three NAWQA study units including the Upper Colorado River Basin (UCOL), Nevada Basin and Range (NVBR), and Central Arizona Basins (CAZB) are located in the CDRB. The NAWQA Program studied water quality in the UCOL of western Colorado from 1996 to 1998 and reported that elemental concentrations exceeded water quality guidelines (Spahr and others, 2000). Specifically, concentrations of $\mathrm{Cd}, \mathrm{Zn}, \mathrm{Cu}$, and $\mathrm{Pb}$ in streambed sediments from historical mining districts could be harmful to aquatic wildlife (Mize and Deacon, 2002; Spahr and others, 2000). In addition, Se was leached out off the irrigation drainage soils in agricultural areas of the Colorado Plateau, causing this area to be the major Se source for Lake Powell (Engberg, 1999). Pesticide concentrations in this area were low and below protective criteria for aquatic wildlife (Spahr and others, 2000). Few biological samples are available, but Deacon and Stephens (1998) measured $\mathrm{Cd}, \mathrm{Se}, \mathrm{Cu}$, and $\mathrm{Zn}$ concentrations in fish liver from the UCOL. Concentrations of $\mathrm{Cd}$ and Se were highest in fish from mining and agricultural areas, respectively, while concentrations of $\mathrm{Cu}$ and $\mathrm{Zn}$ were highest in areas of mixed land-use (Deacon and Stephens, 1998).

The NVBR study unit, which includes the Las Vegas Valley in southern Nevada, was sampled in 1992-1996 (Bevans and others, 1996). The NAWQA Program determined that urban activities in the Las Vegas Valley have contributed nutrients (ammonia, nitrate), synthetic organic compounds (herbicides, insecticides, trihalomethanes, methyl tert-butyl ether), organochlorines (polycyclic aromatic hydrocarbons (PAHs), phenols, phthalate esters), and trace elements (Cd, $\mathrm{Cu}$, chromium $(\mathrm{Cr}), \mathrm{Pb}$, and $\mathrm{Zn}$ ) to surface water and sediments in the Las Vegas Wash (Bevans and others, 1998). The Las Vegas Wash receives large quantities of sewage effluent from Las Vegas and surrounding areas. Chemicals in the effluent are eventually discharged into Las Vegas Bay of Lake Mead via the Las Vegas Wash and may be transported further downstream in the CDR. Several studies have found evidence of endocrine disruption in carp in the Las Vegas Wash and Las Vegas Bay of Lake Mead (Bevans and others, 1996; Gross and others, 2004; Patiño and others, 2003b).

The NAWQA Program initiated water quality studies in the CAZB in 1994. Gebler (2000) reported on the occurrence and distribution of organochlorine compounds in tissues of aquatic biota in CAZB streams. Organic and inorganic contaminants also entered the CAZB from industrial, mining, agricultural, and municipal activities in Mexico (Cordy and others, 1998; Gellenbeck and Anning, 2002). Water use in this area is dominated by agriculture, primarily cotton, which introduces organochlorines into multiple streams and rivers. Water quality in CAZB streams in urbanized areas is poor due to flow being composed primarily of sewage effluent. Concentrations of total DDT and toxaphene exceeded criteria to protect piscivorous wildlife in fish collected near a wastewater treatment facility in western Phoenix and in Buckeye Canal near Hassayampa (Gebler, 2000). Concentrations of PCBs also exceeded protective wildlife criteria in fish tissues from Buckeye Canal.

The NIWQP was initiated in the mid-1980s to identify and address water quality and contamination problems, specifically Se contamination from irrigation, in the western U.S. Reconnaissance investigations included five areas in the CDRB: the San Juan River area in New Mexico, the Dolores-Ute Mountain area and Gunnison-Grand Valley (GGV) in Colorado, the Middle Green River Basin in Utah, and the Lower Colorado River Valley in Arizona and California (Seiler and others, 1999). Remediation planning, based upon results of reconnaissance and detailed studies, began in the GGV and MGR areas to reverse adverse impacts to fish and wildlife from irrigation projects.

NIWQP activities in the GGV focused on degraded fish habitat and Se loading in the Gunnison River Basin (Butler and Leib, 2002). NIWQP and other groups working in the GGV proposed flushing channels and alternative uses of irrigation drainage as remediation processes for backwater and bottomland sites used by endangered fish in the Grand Valley. Most Se is the result of irrigation drainage in the Uncompahgre River Basin near Montrose and Delta, Colorado. Remediation efforts include reducing irrigation seepage from ponds and irrigation ditches, phytoremediating to remove Se from top soil, and developing management practices for Se sources unrelated to agriculture. The MGR area is located near Stewart Lake Wildlife Management Area near Vernal, Utah, and Stewart Lake has received irrigation drainage since the early 1980s as a stable water supply. Selenium has contaminated water, sediments, and biota. Deformed embryos and reduced hatch success has been documented in migratory birds in the lake and outfall to the Green River (Stephens and others, 1992). Diversions were constructed to redirect irrigation drainage from the Lake Stewart to the Green River. Proposed remediation efforts include flushing contaminated sediments, mechanical (tilling) and chemical options, and bioremediation. However, NIWQP became inactive in 2004, and remediation efforts ended.

The San Juan River Seven-Year Research Program (SJRP), under the auspices of the San Juan River Basin Recovery Implementation Program, was initiated in the early 1990s. A primary goal of the program was to review water quality and contaminant information in the SJB (Abell, 1994). Irrigation and mineral extraction and processing were identified as the major sources of contaminants in the SJB. The SJRP recommended that future research should include the effects of Se on rare fish, the sources and effects of PAHs, and correlation of degraded fish health with contaminants (Abell, 1994).

The USFWS has conducted multiple studies on environmental contaminants in fish associated with agricultural drainage canals in the Lower CDRB. The GRB provides important habitat for Threatened and Endangered species, migratory birds, and waterfowl. Agricultural canals have transported pesticides to the GR and contributed to elevated concentrations of organochlorines and metals in fish (Baker and others, 1992; García-Hernández and others, 2001; King and others, 
1997). Numerous migratory waterfowl use the delta system of the Lower CDRB and may be exposed to agricultural pesticides in this area (Baker and others, 1992; García-Hernández and others, 2001, 2006). Copper mining operations instead of agricultural or municipal discharges are the primary source of contaminants in the Middle GR from Coolidge Dam to the Ashurst-Hayden Dam (King and Baker, 1995). The Ray copper mine contaminated Mineral Creek, a tributary to the GR, which resulted in high concentrations of $\mathrm{Cu}, \mathrm{Pb}$, and $\mathrm{Zn}$ in fish; however, the overall ecology of the creek improved after renovations at the mine (Andrews and King, 1997).

Irrigation drainage waters in the Yuma Valley of southern Arizona are potentially harmful to fish and wildlife (Baker and others, 1992). Concentrations of toxaphene, $p, p$ '-DDE, dieldrin, and total chlordane in fish tissue were consistent with historical NCBP concentrations, but $p, p^{\prime}$-DDD and $p, p$ '-DDT concentrations have decreased in fish tissue (Baker and others, 1992). In addition, concentrations of $\mathrm{As}, \mathrm{Cu}$, and $\mathrm{Se}$ exceeded protective criteria for fish, and concentrations of As and $\mathrm{Cu}$ in fish have increased in the Yuma Valley since the late 1970s (Baker and others, 1992).

King and others (1997) measured pesticides and metals concentrations in fish and wildlife in the Lower GRB. The greatest mean concentration of $p, p$ '-DDE $(11.17 \mu \mathrm{g} / \mathrm{g})$ documented in the U.S. from areas associated with agriculturally applied pesticides was measured in common carp from Buckeye Canal (King and others, 1997). Concentrations of $p, p$ '-DDE have declined even though current levels remain extremely high in fish collected from GR tributaries and canals. Concentrations of other pesticides and PCBs were less than protective criteria for fish and wildlife (King and others, 1997). Copper was detected at high concentrations ( $>5 \mu \mathrm{g} / \mathrm{g})$ in carp and channel catfish and remains a concern due to its tendency to interact with other compounds and elements (King and others, 1997).

The USFWS measured Se and other trace elements in sediment and fish from Imperial, Cibola, and Havasu NWRs along the Lower CDR in the late 1980s (King and others, 1993). Concentrations of $\mathrm{As}$ and $\mathrm{Hg}$ in fish were below protective criteria for piscivorous wildlife, and only one sample exceeded criteria for Cd. Concentrations of Se (0.89-4.39 $\mu \mathrm{g} / \mathrm{g}$ ) exceeded the minimum threshold level shown to cause reproductive impairment in fish but remained stable from 1984 to 1989 (King and others, 1993). The study recommended that each NWR consider issuing fish consumption advisories in selected areas with known high Se concentrations. A subsequent study by Andrews and others (1997) measured organochlorines and inorganic contaminants in fish and wildlife of the Havasu NWR in Arizona. Arsenic, Cd, Cr, $\mathrm{Cu}, \mathrm{Pb}$, and $\mathrm{Se}$ concentrations were potentially hazardous to fish and wildlife in the area, but organochlorine concentrations were below protective wildlife criteria (Andrews and others, 1997). Concentrations of Se in largemouth bass and common carp ranged from 0.79 to $2.60 \mu \mathrm{g} / \mathrm{g}$, which were considered potentially lethal for piscivorous wildlife. Andrews and others (1997) concluded that further investigations on the effects of
Se in fish and piscivorous birds should be a priority in this area of the Lower CDRB.

\section{Materials and Methods}

\section{Collection Sites}

Fish were collected at fourteen sites in the CDRB (fig. 1; table 2). Six of the 14 sites were located on the CDR, two were on the Green River, three were on the Gila River, and one each was on the Yampa, Gunnison, and San Juan Rivers. Stations were grouped into two sub-basins, the Upper CDRB and Lower CDRB. Fish were collected post-spawn between August and October 2003 (table 2). Sampling at each site was completed during one visit spanning 1-3 days.

\section{Target Species and Sampling Strategy}

This study was designed to retain comparability with previous investigations which measured chemical concentrations in whole fish composite samples, while also accommodating biological measurements, many of which are gender-specific and require live or freshly killed individual fish, incorporated into the BEST Program's Large River Monitoring Network (LRMN; Schmitt and Dethloff, 2000). The same species were targeted at each site to standardize fish health and reproductive biomarker results. The most prevalent bottom-dwelling species and predator species were common carp (henceforth carp) and largemouth bass (Micropterus salmoide), respectively, in previous NCBP collections (Schmitt and others, 1999). These were also the targeted species in other BEST-LRMN investigations (Hinck and others, 2004a; Schmitt, 2002; Schmitt and others, 2004). These species have a widespread distribution, abundant extant contaminant data, and biological endpoint data and were the preferred taxa at all sites. Alternate species were permitted if these taxa could not be obtained. Preferred alternate species included white sucker (Catostomus commersoni) as alternate benthivores, and smallmouth bass (henceforth Micropterus sp., bass), channel catfish, brown trout (Salmo trutta) and flathead catfish (Pylodictis olivaris) as piscivores. The collection target at each site was 10 (each) adult male and female of each taxon for a total of 40 fish per site. Adult carp and bass of a size representative of those believed to be present based on extant information were preferred and extremely large or small fish were avoided. More than two species were collected at sites if the quota for the target taxa could not be obtained.

\section{Monitoring Methods Overview}

A suite of chemical and biological methods including reproductive biomarkers, measures of cytochrome $\mathrm{P} 450$ 
Table 2. Stations sampled in 2003 and collection date (first-last) in the Colorado River Basin. Stations are grouped by sub-basin and ordered upstream to downstream.

\begin{tabular}{|c|c|c|c|c|}
\hline Sub-basin and river & $\begin{array}{l}\text { Station } \\
\text { number }\end{array}$ & Nearby landmark & Collection dates & Latitude, Longitude \\
\hline \multicolumn{5}{|c|}{ Upper Colorado River Basin } \\
\hline Yampa & 311 & Lay, CO & $10 / 21 / 03-10 / 23 / 03$ & $40^{\circ} 25^{\prime} 38.00^{\prime \prime} \mathrm{N}, 107^{\circ} 51^{\prime} 24.00^{\prime \prime} \mathrm{W}$ \\
\hline Green & 312 & Ouray NWR, UT & 9/8/03-9/9/03 & $40^{\circ} 08^{\prime} 31.00^{\prime \prime} \mathrm{N}, 109^{\circ} 39^{\prime} 17.00^{\prime \prime} \mathrm{W}$ \\
\hline Green & 313 & San Rafael, UT & $9 / 5 / 03-9 / 6 / 03$ & $38^{\circ} 45^{\prime} 56.00^{\prime \prime} \mathrm{N}, 110^{\circ} 05^{\prime} 16.00^{\prime \prime} \mathrm{W}$ \\
\hline Gunnison & 314 & Delta, CO & $9 / 6 / 03-9 / 7 / 03$ & $38^{\circ} 45^{\prime} 59.58^{\prime \prime} \mathrm{N}, 108^{\circ} 02^{\prime} 30.30^{\prime \prime} \mathrm{W}$ \\
\hline Colorado & 315 & Loma, $\mathrm{CO}$ & $9 / 9 / 03-9 / 11 / 03$ & $39^{\circ} 09^{\prime} 39.00^{\prime \prime} \mathrm{N}, 108^{\circ} 48^{\prime} 28.56^{\prime \prime} \mathrm{W}$ \\
\hline Colorado & 316 & Gold Bar Canyon, UT & $9 / 3 / 03-9 / 4 / 03$ & $38^{\circ} 34^{\prime} 02.00^{\prime \prime} \mathrm{N}, 109^{\circ} 38^{\prime} 51.00^{\prime \prime} \mathrm{W}$ \\
\hline San Juan & 317 & Hogback Diversion, NM & $9 / 3 / 03-9 / 4 / 03$ & $36^{\circ} 44^{\prime} 41.00^{\prime \prime} \mathrm{N}, 108^{\circ} 41^{\prime} 28.00^{\prime \prime} \mathrm{W}$ \\
\hline \multicolumn{5}{|c|}{ Lower Colorado River Basin } \\
\hline Colorado & 319 & South Cove, AZ & $10 / 1 / 03$ & $36^{\circ} 05^{\prime} 23.70^{\prime \prime} \mathrm{N}, 114^{\circ} 06^{\prime} 12.30^{\prime \prime} \mathrm{W}$ \\
\hline Colorado & 320 & Willow Beach, AZ & $9 / 29 / 03-9 / 30 / 03$ & $35^{\circ} 52^{\prime} 33.12^{\prime \prime} \mathrm{N}, 114^{\circ} 39^{\prime} 53.10^{\prime \prime} \mathrm{W}$ \\
\hline Colorado & 321 & Needles, CA & $9 / 23 / 03-9 / 24 / 03$ & $34^{\circ} 43^{\prime} 44.64^{\prime \prime} \mathrm{N}, 114^{\circ} 20^{\prime} 12.96^{\prime \prime} \mathrm{W}$ \\
\hline Colorado & 322 & Imperial Dam, AZ & $9 / 25 / 03-9 / 26 / 03$ & $32^{\circ} 54^{\prime} 05.94^{\prime \prime} \mathrm{N}, 114^{\circ} 28^{\prime} 09.48^{\prime \prime} \mathrm{W}$ \\
\hline Gila & 323 & Hayden, AZ & $8 / 22 / 03-8 / 23 / 03$ & $33^{\circ} 01^{\prime} 22.14^{\prime \prime} \mathrm{N}, 110^{\circ} 44^{\prime} 16.32^{\prime \prime} \mathrm{W}$ \\
\hline Gila & 324 & Phoenix, AZ & $8 / 25 / 03-8 / 27 / 03$ & $33^{\circ} 22^{\prime} 33.42^{\prime \prime} \mathrm{N}, 112^{\circ} 18^{\prime} 19.20^{\prime \prime} \mathrm{W}$ \\
\hline Gila & 325 & Arlington, AZ & 8/18/03-8/20/03 & $33^{\circ} 19^{\prime} 06.92^{\prime \prime} \mathrm{N}, 112^{\circ} 40^{\prime} 26.46^{\prime \prime} \mathrm{W}$ \\
\hline
\end{tabular}

enzyme induction, fish health assessments, and chemical analyses of fish carcasses was used to characterize the exposure of fish to contaminants and the effects of exposure (table 3 ; Schmitt and Dethloff, 2000). Concurrent determination of tissue residue concentrations along with the suite of fish health, immune system responses, and reproductive assessments supports the interpretation of relationships between exposure and biological responses.

Multiple organochlorine chemical residues and elemental contaminants were measured in the whole-body fish composite samples (table 4). These analytes were selected to provide the maximum amount of information on accumulative contaminants of interest at minimal cost and to maintain continuity with the historical NCBP database. Instrumental analyses of specific planar halogenated hydrocarbons (PHHs), such as polychlorinated dibenzo- $p$-dioxin (PCDD) and polychlorinated dibenzofuran (PCDF) congeners, were excluded due to their high analysis cost. Instead, extracts of the composite samples were screened with the H4IIE rat hepatoma cell bioassay (Tillitt and others, 1991; Whyte and others, 2004), which responds to planar PHHs (table 5). Ethoxyresorufin $O$ deethylase (EROD) activity, which indicates recent exposure to exogenous aryl hydrocarbon receptor (AhR) ligands including PHHs and PAHs, were measured in the livers of individual fish (Kennedy and Jones, 1994; Pohl and Fouts, 1980; Whyte and others, 2000). Together these assays and analyses allowed for the estimation of the relative concentrations of potential biological effects of PHHs and PAHs without the expense of instrumental analyses for these compounds (table 5).
Measurements of fish health, immune system responses, and reproductive status were included in the suite of indicators to examine potential impacts from non-accumulative contaminants and contaminant mixtures (table 3 ). Fish health indicators included gross observations for abnormalities, condition and organosomatic indices, and histopathological examination (Goodbred and others, 1997; Hinton, 1993; Hinton and others, 1992). Gross observations and determination of indices based on relative fish and organ sizes such as condition factor (CF), hepatosomatic index (HSI), and splenosomatic index (SSI) are relatively simple and indicative of cumulative, organism-level changes (Grady and others, 1992). However, these indicators are non-specific in terms of causal mechanisms and may reflect early, subtle alterations and foreshadow subsequent effects at the individual- or population-level.

The SSI is an indicator of overall organism health as well as a measure of immune system stress. Other immune system indicators included the measurement of macrophage aggregates (MA) in preserved spleen tissue samples (table 3). Macrophage aggregates, also known as melanomacrophage centers, are discrete aggregations of pigment-bearing macrophages found in spleen, kidney, and sometimes liver of advanced teleosts (Agius, 1980). Pigmented cell accumulations can also occasionally found in the gonad and other tissues. These specialized cells are thought to be responsible for centralizing foreign material and debris for destruction, detoxification or reuse, storing waste products, contributing to the immune response, and storing/recycling iron (Ellis and others, 1976; Ferguson, 1976). MA measurements have responded to 


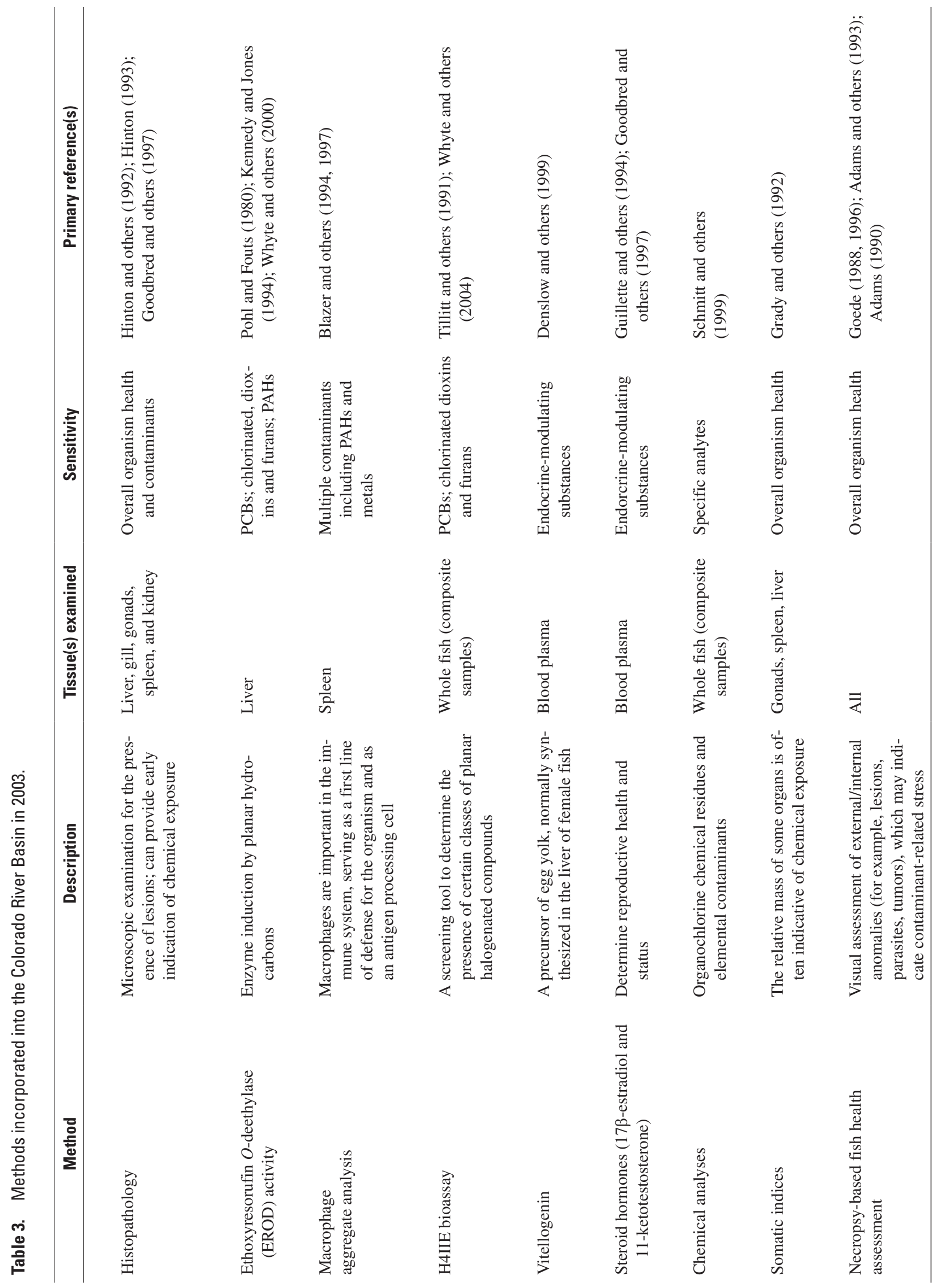


Table 4. Organochlorine chemical and elemental contaminants measured in whole-body fish composite samples.

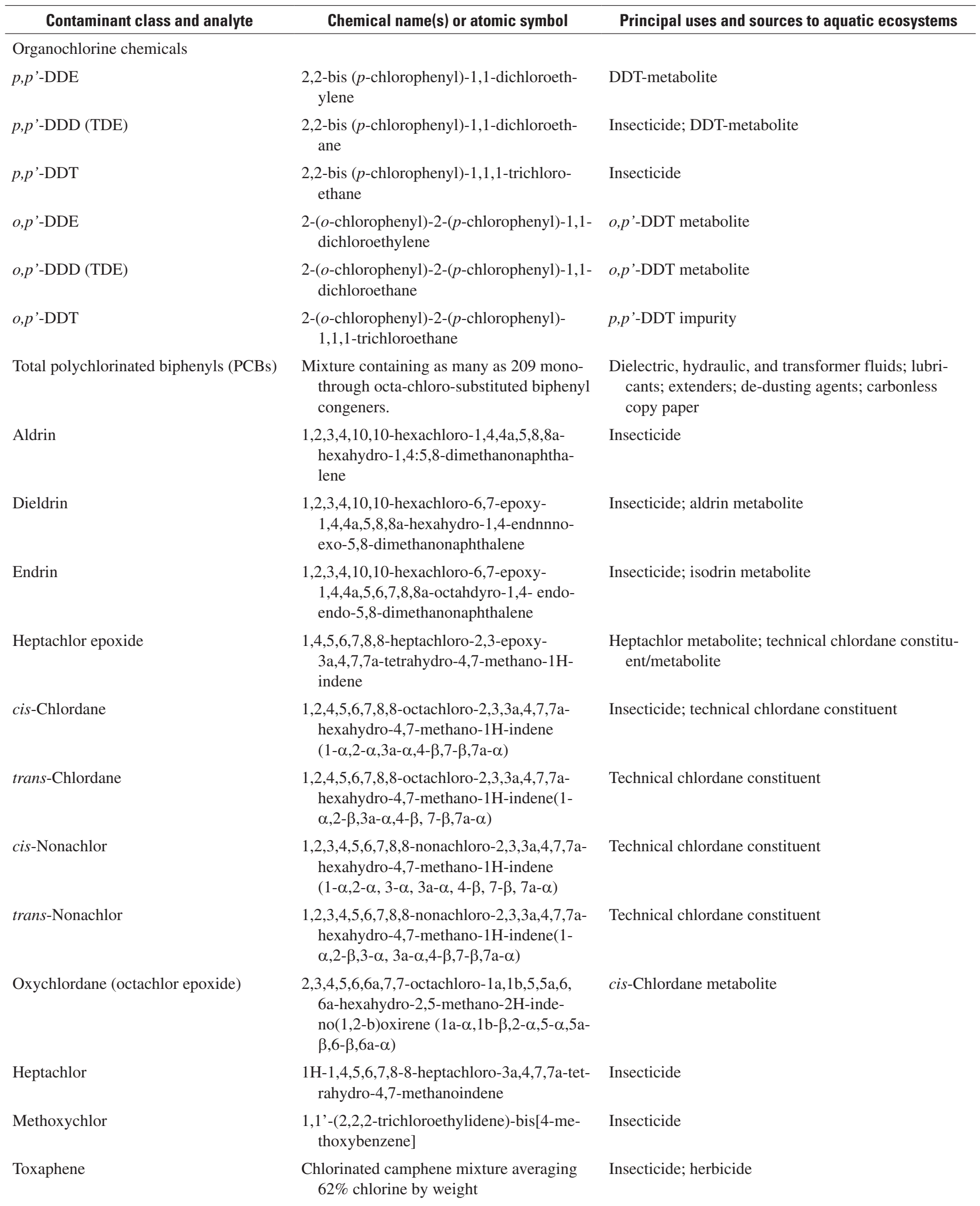


Table 4. Organochlorine chemical and elemental contaminants measured in whole-body fish composite samples.—Continued

\begin{tabular}{|c|c|c|}
\hline Contaminant class and analyte & Chemical name(s) or atomic symbol & Principal uses and sources to aquatic ecosystems \\
\hline$\alpha$-Hexachlorocyclohexane $(\mathrm{HCH})$ & 1,2,3,4,5,6-hexachlorocyclohexane & $\begin{array}{l}\text { Constituent of insecticide mixture containing various } \\
\mathrm{HCH} \text { isomers; also know as } \alpha \text {-benzene hexachlo- } \\
\text { ride (BHC) }\end{array}$ \\
\hline$\beta-\mathrm{HCH}$ & 1,2,3,4,5,6-hexachlorocyclohexane & Technical HCH (BHC) constituent \\
\hline$\delta-\mathrm{HCH}$ & 1,2,3,4,5,6-hexachlorocyclohexane & Technical HCH (BHC) constituent \\
\hline Pentachlorobenzene & Chlorinated benzene & Fungicide; fire retardant \\
\hline Pentachloroanisole & Chlorinated benzene & $\begin{array}{l}\text { Fungicide; metabolite of chlorinated aromatic chemi- } \\
\text { cals }\end{array}$ \\
\hline Endosulfin I ( $\alpha$-Endosulfan) & $\begin{array}{l}\text { 6,9-methano-2,4,3-benzodioxathi- } \\
\text { epin,6,7,8,9,10,10-hexachloro- } \\
\text { 1,5,5a,6,9,9a }\end{array}$ & Pesticide \\
\hline Endosulfan sulfate & $\begin{array}{l}\text { 6,7,8,9,10,10-hexachloro-1,5,5a,6,9,9a- } \\
\text { hexahydro-6,9-methano,2,4,3-benodia- } \\
\text { tiepin 3,3-dioxide }\end{array}$ & Endosulfan byproduct \\
\hline Dacthal & $\begin{array}{l}\text { dimethyl-2,3,5,6-tetrachlorobenzene-1,4- } \\
\text { dicarboxylic acid }\end{array}$ & $\begin{array}{l}\text { Herbicide; may contain dioxin }(2,3,7,8-\mathrm{TCDD}) \text { and } \\
\text { HCB as impurities }\end{array}$ \\
\hline Mirex & $\begin{array}{l}\text { 1,1a,2,2,3,3a,4,5,5,5a,5b,6-dodeca- } \\
\text { chloro-octahydro-1,3,4-metheno- } 1 \mathrm{H} \text { - } \\
\text { cyclobuta(cd)pentalene }\end{array}$ & Insecticide; fire retardant \\
\hline Lead & $\mathrm{Pb}$ & $\begin{array}{l}\text { Mining, smelting and other industrial sources; urban } \\
\text { runoff; atmospheric pollution; fishing sinkers; lead } \\
\text { shot }\end{array}$ \\
\hline Mercury & $\mathrm{Hg}$ & $\begin{array}{l}\text { Herbicides; fungicides; pulp, paper, and textile efflu- } \\
\text { ents; open-cycle chloralkali cells; landfills; mining; } \\
\text { atmospheric pollution }\end{array}$ \\
\hline Nickel & $\mathrm{Ni}$ & Mining, smelting, and other industrial sources \\
\hline Selenium & $\mathrm{Se}$ & Coal-fired powerplants; irrigation return flows \\
\hline Zinc & $\mathrm{Zn}$ & $\begin{array}{l}\text { Mining, smelting and other industrial sources; urban } \\
\text { runoff }\end{array}$ \\
\hline
\end{tabular}


Table 5. Monitoring and assessment strategy for polycyclic aromatic and polyhalogenated hydrocarbons (PAHs and PHHs). ${ }^{a}$ Total PCBs were determined by gas chromatography with electron-capture detection. ${ }^{b}$-ethoxyresorufin 0-deethylase. ${ }^{c} \mathrm{H} 4 \mathrm{IIE}$ bioassay was performed after reactive cleanup to remove aryl hydrocarbon receptor (AhR)-active PAHs. ${ }^{\mathrm{d} A n d}$ other planar organic compounds. + responds; - does not respond; *AhR-active isomers and congeners only.

\begin{tabular}{lccc}
\hline & \multicolumn{3}{c}{ Contaminants } \\
\cline { 2 - 4 } \multicolumn{1}{c}{ Endpoint } & PCBs & $\begin{array}{c}\text { PCDDs } \\
\text { \& } \\
\text { PCDFs }\end{array}$ & PAHs $^{\mathrm{d}}$ \\
\hline GC-ECD $^{\mathrm{a}}$ (carcass) & + & - & - \\
EROD activity & & & $*$ \\
H4IIIE bioassay & & $*$ & \\
\hline
\end{tabular}

contaminant exposure in both field and laboratory studies although they may be affected by a variety of factors (reviews by Wolke, 1992 and Blazer and others, 1997).

Measures of reproductive condition included plasma vitellogenin (vtg) and sex steroid hormone concentrations, gonadosomatic index (GSI), and gonadal histopathology (table 3). Contaminants, particularly estrogen mimics, have been shown to impact reproduction in laboratory and field studies, although the reproductive condition in fish can be influenced by many factors including gender, age, reproductive stage, season, and water temperature (Allen and others, 1999; Gimeno and others, 1998). Estrogen mimics are capable of stimulating the production of vtg, a precursor of yolk protein, in the livers of oviparous vertebrates, and a number of endocrine disrupting compounds have been shown to induce abnormal vitellogenesis (Servos, 1999; Tyler and others, 1998). Vitellogenin production is normally associated with female fish, but vtg can be produced in males if estrogen or an estrogen-like chemical is present. The detection of concentrations typical of early- to mid-vitellogenic females in male fish has been associated with exposure to exogenous estrogens (Bowman and others, 2002; Denslow and others, 1999; Folmar and others, 1996, 2000, 2001), but low vtg concentrations in males may be normal for certain species (Gross and others, 2002). Vitellogenin was measured in both male and female CDRB fish to document these and other possible alterations. The GSI and gonadal histopathology [reproductive stage, presence of atretic oocytes, and intersex condition (presence of female reproductive tissue in males or vice-versa)] were also assessed as measures of reproductive health and status. The GSI relates the proportional size of the gonad to the body size and may reflect changes resulting from a variety of physiological factors such as reproductive stage and environmental factors, including exposure to contaminants. Elevated occurrence of atretic (unfertilized, reabsorbed, or both) eggs has been noted in fish exposed to contaminants (Cross and Hose, 1988; Johnson and others, 1988), although other factors may also be involved. Feminization of male fish (that is, intersex condition) has been reported in laboratory and field studies of contaminants (Allen and others, 1999; Gimeno and others, 1997, 1998; Jobling and others, 1998) and in previous LRMN studies (Blazer and others, 2002; Hinck and others, 2004a; Schmitt and others, 2004). Reproductive biomarkers can vary with temperature, photoperiod, and annual reproductive cycle. To minimize the effect of these factors on the reproductive biomarkers, all fish were collected post-spawn. Carp, bass, and channel catfish are annual spawners that typically spawn from April to June in the CDRB. All fish in our study were collected within eight weeks of one another from August 18 to October 23.

\section{Fish Collection}

Fish were collected by boat electrofishing along the shoreline or backwater areas of the river being sampled. All specimens of the target species were collected, irrespective of size, although electrofishing tends to be biased toward larger fish (Reynolds, 1983). More than 10 fish of a given species and gender were collected at some sites. GPS coordinates were obtained for the upstream and downstream locations at the sampling site in which fish were collected. Fish were held in on-board live wells and transported to shore for processing, usually within a few hours of collection. Fish at certain stations were held alive overnight in tanks or net pens containing ambient river water following night collections.

\section{Sample Processing}

A live fish was selected and identified to species. A blood sample was collected from the posterior caudal artery and vein with a heparinized needle and syringe and placed on wet ice. Plasma from this blood sample was later obtained for determination of vtg and steroid hormone concentrations. The fish was weighed, measured, and killed with a blow to the head. Observations of external features were recorded, and tissue anomalies were removed by dissection and preserved in $10 \%$ neutral buffered formalin (NBF) for histopathological analysis. The abdominal cavity was dissected open and the liver, spleen, and gonads were removed and weighed. Liver weights for carp and sucker were not determined because these species have a dispersed hepatopancreas. The liver, gall bladder, posterior and anterior kidneys, gonads, mesenteric fat (in certain species), and spleen were examined, and the gender of the fish was determined. Pieces of liver collected for EROD analysis were immediately flash-frozen in a dry ice-ethanol slurry, then transferred to dry ice for storage and shipment. Samples of gonad, kidney, spleen, and additional pieces of liver were collected and preserved in $10 \%$ NBF for histopathological examination, gender confirmation (gonad), and macrophage aggregate analysis (spleen). Upon comple- 
tion of the internal examination and dissection, otoliths (asterisci in carp, sagitta in bass), scales, and/or spines were collected for age determination. Remaining tissues (those not frozen or fixed) were placed back into the body cavity and the entire fish was wrapped in aluminum foil. The wrapped carcass was labeled and placed in a bag with other carcasses of the same species and gender. These samples were chilled and later frozen for analysis of organochlorine chemical and elemental contaminants and dioxin-like activity. The entire field procedure was typically conducted in 15-20 min (per fish), and tissue samples, especially liver for EROD analysis, were collected and frozen as rapidly as possible. Blood samples were centrifuged, and the plasma was drawn off with a transfer pipette into a cryovial and frozen in dry ice following the processing of the fish.

\section{Laboratory Analysis}

Fish samples were shipped frozen on dry ice to the Columbia Environmental Research Center (CERC) of the USGS and stored frozen $\left(-20^{\circ} \mathrm{C}\right)$ until analyzed. CERC performed analyses of composite fish samples for organic and elemental contaminants and completed quality assurance (QA) and quality control (QC) procedures described in Hinck and others (2004b). Fish were homogenized and lyophilized by LET, Inc. (Columbia, Missouri) according to protocols provided by CERC. Cryogenically frozen liver samples for EROD analysis were also shipped on dry ice to CERC for analysis. Cryogenically frozen plasma samples were similarly shipped to the Center for Environmental and Human Toxicology of the University of Florida for analysis of vtg and the Florida-Caribbean Science Center of the USGS for analysis of sex steroid hormones. Preserved tissue samples were shipped to the National Fish Health Laboratory of the USGS Leetown Science Center and Colorado Histo-Prep (Fort Collins, Colorado) for histopathological analysis. Information on these latter procedures are given by Blazer and others (2002) and McDonald and others (2002). Age determination was conducted by L. Stanley (Tottenham, Ontario) and confirmed by the USGS South Carolina Cooperative Fish and Wildlife Research Unit (Clemson, South Carolina). Scales were processed for age determination when otoliths were unavailable by estimating age (years) from the number of completed annuli (Berg and Grimaldi, 1967; Hesthagen, 1985). Transverse section of otoliths (asterisci in carp, sagitta in bass) and spines were processed for age determination following modified procedures from Cowan and others (1995) and Casselman (1987, 1990). Annual growth increments (annuli) were designated at the distal edge of an opaque zone imbedded between two translucent zones. As collection period varied and samples were examined in the blind, ages were reported as the number of increments regardless of time of year.

\section{Composite Sample Preparation}

Individual fish carcasses were composited by gender and species and prepared by band-sawing and grinding with a commercial meat grinder. All equipment was disassembled and chemically cleaned between composite samples to prevent cross contamination. One sub-sample $(\sim 100 \mathrm{~g})$ of the composite was refrozen $\left(-20^{\circ} \mathrm{C}\right)$ for analysis of moisture content and lyophilized prior to elemental contaminant determination; a second $(\sim 10 \mathrm{~g})$ sample was retained for organochlorine chemical residues by GC-ECD and gravimetric determination of lipid content; and a third $(\sim 10 \mathrm{~g})$ sample was extracted with methylene chloride, subjected to the reactive cleanup procedure and ampulated for use in the H4IIE bioassay. These methods have been described previously (Hinck and others, 2004b).

\section{Elemental Contaminants and Moisture Content}

Sub-samples for elemental analyses $(\sim 100 \mathrm{~g})$ were freezedried, and percent moisture was determined as weight lost during lyophilization. One portion of the dried material was digested in nitric acid and analyzed by inductively coupled plasma mass spectroscopy (ICP-MS) for the determination of $\mathrm{Cd}, \mathrm{Cr}, \mathrm{Cu}, \mathrm{Fe}, \mathrm{Pb}, \mathrm{Ni}$, and $\mathrm{Zn}$. A homogenized aliquot of each dried sample $(\sim 0.25 \mathrm{~g})$ was heated with $6 \mathrm{~mL}$ of nitric acid in a sealed low-pressure Teflon ${ }^{\circledast}$ vessel in a microwave oven. The cooled digestate liquid was transferred to a $125 \mathrm{~mL}$ polyethylene bottle and ultrapure $\mathrm{H}_{2} \mathrm{O}(>10 \mathrm{megOhm} / \mathrm{cm})$ was added, yielding a final weight of $101.5 \mathrm{~g}(100 \mathrm{~mL})$. The final acid matrix was $6 \% \mathrm{HNO}_{3}$. All samples were diluted $10 \mathrm{X}$ by a CETAC ASD-500 auto-diluter as part of the analytical sequence. Internal standards were germanium $(50 \mathrm{ng} / \mathrm{g})$, rhodium $(10 \mathrm{ng} / \mathrm{g})$, and thorium $(10 \mathrm{ng} / \mathrm{g})$. The external standard consisted of a NIST traceable reference solution to which five elements (praseodymium, terbium, thulium, tantalum, and gold) were added for improved calibration in the rare earth region of the mass spectral range. A second portion $(\sim 0.5$ g) was dry-ashed (magnesium nitrate-nitric acid- $\mathrm{HCl}$ ) and analyzed by hydride generation atomic absorption spectroscopy for As and Se. The dry ashing procedure consisted of three steps: 1) boiling with nitric acid for solubilization and partial oxidation; 2) $500^{\circ} \mathrm{C}$ ashing with magnesium nitrate to complete the oxidation and decompose remaining organic matter; and 3) heating with $\mathrm{HCl}$ to dissolve the ash and reduce $\mathrm{Se}^{+6}$ to the $\mathrm{Se}^{+4}$ oxidation state required for hydride generation. Digestates were diluted following the $\mathrm{HCl}$ reduction to $\sim 100 \mathrm{~mL}$ with de-ionized water that yielded a final acid matrix of $10 \% \mathrm{HCl}$. The digestates were mixed with $\mathrm{HCl}$ carrier solution and reduced by sodium tetrahydridoborate which was stabilized with sodium hydroxide. The resulting volatile hydrogen selenide or arsenide was transferred with argon carrier gas into a heated quartz cell mounted on an atomic absorption spectrophotometer for decomposition and measurement. A third portion was analyzed directly for total $\mathrm{Hg}$ using 
thermal combustion, amalgamation, and atomic absorption spectroscopy.

Quality assurance (QA) measures for elemental determinations included the analysis of reagent blanks, replicate samples, certified reference materials, and fortified samples. Nominal LODs were $0.018 \mu \mathrm{g} / \mathrm{g} \mathrm{dw}$ for As, $0.0007 \mu \mathrm{g} / \mathrm{g} \mathrm{dw}$ for $\mathrm{Hg}, 0.014 \mu \mathrm{g} / \mathrm{g} \mathrm{dw}$ for Se, $0.1 \mu \mathrm{g} / \mathrm{g} \mathrm{dw}$ for $\mathrm{Cd}$, and $1.0 \mu \mathrm{g} / \mathrm{g}$ $\mathrm{dw}$ for $\mathrm{Cr}, \mathrm{Ni}$, and $\mathrm{Pb}$ (Appendix 2). Elemental concentrations (including LODs) were converted from dry-weight (dw) to wet-weight (ww) for statistical analysis and reporting using the moisture content of each sample, which ranged from 66 to $76 \%$.

\section{Organochlorine Contaminants and Lipid Content}

One sub-sample $(\sim 10 \mathrm{~g})$ was solvent-extracted and analyzed gravimetrically for lipid content (range: $2-12 \%$ ) and by high-resolution capillary gas chromatography with electron capture detection (GC-ECD) for 29 organochlorine pesticide residues and total polychlorinated biphenyls (PCBs; Appendix 3). Total PCBs were calculated and reported as the sum of 139 congeners. The analytical procedure began with blending anhydrous sodium sulfate with the composite sub-sample. Targeted chemicals were then extracted from the dried sample with dichloromethane. The extract was quantitatively split into portions for H4IIE bioassay (80\%), OCP/PCB/toxaphene analyses (8\%), percent-lipid determination (2\%), and archive (10\%). The analytical portion was spiked with the following chemical standards to track method recoveries: PCB 029 (2,4,6-trichlorobiphenyl) for early-eluting PCBs $\left(\mathrm{Cl}_{1}-\mathrm{Cl}_{3}\right)$; PCB 155 (2,2',4,4',6,6'-hexachlorobiphenyl) for mid-range eluting congeners $\left(\mathrm{Cl}_{4}-\mathrm{Cl}_{6}\right)$, PCB 204 (2,2',3,4,4',5,6,6'-octachlorobiphenyl) for later-eluting $\mathrm{PCBs}\left(\mathrm{Cl}_{7}-\mathrm{Cl}_{10}\right)$, tetrachloro-m-xylene, and dibutylchlorendate. Quality assurance measures for the organochlorine analyses included the analysis of triplicate and fortified samples, use of internal standards to monitor recoveries of each sample, and the confirmation of residue identities by dual-column gas chromatography-electron capture detection.

The analytical portion was purified by removing interfering co-extracted lipids and biogenic materials prior to the gas chromatographic quantification. Most interferences were removed by low-pressure size-exclusion chromatography (LPSEC). High performance SEC (HPSEC) was used to remove residual interferences. A two-layered octadecyl silica/activated silica gel column was used to separate the organochlorine pesticide residues from the PCBs prior to gas chromatography (GC) analysis. Dual-column GC-ECD data were used to confirm organochlorine pesticide identities. Total toxaphene concentrations were determined by quantifying 20 component peaks in a technical toxaphene standard. Nominal LODs were $\leq 1.4 \mathrm{ng} / \mathrm{g}$ for individual compounds, $48 \mathrm{ng} / \mathrm{g}$ for total PCBs, and $24 \mathrm{ng} / \mathrm{g}$ for toxaphene. Polybrominated diphenyl ethers (PBDEs) present in samples from Stations 324 and 325 interfered with $o, p^{\prime}$-DDT and $p, p$ '-DDD. These samples were subjected to an additional cleanup step and re-evaluated by gas chromatography with mass spectrometry (GC-MS) to accurately quantify the DDTs with PBDE interferences.

\section{H4IIE Rat Hepatoma Cell Bioassay}

Sub-samples for H4IIE analysis were kept frozen at CERC until the initiation of sample processing. Details of processing have been previously described (Schmitt and others, 2002; Whyte and others, 2004). Briefly, samples were thawed, homogenized, and extracted from a column with methylene chloride. Percent lipid was determined on a $1 \%$ portion of the extract. The remainder was concentrated and cleaned up by two-stage column chromatography. Extracts were evaporated, re-dissolved with isooctane and ampulated. Matrix QC of prepared samples (blanks and spikes) included ground tissues from laboratory-raised bluegill (Lepomis macrochirus) and samples of a CERC standard positive control tissue (carp from Saginaw Bay, Michigan).

The H4IIE rat hepatoma cells were seeded at 23,000 cells/well in $300 \mu \mathrm{L}$ of D-MEM culture media (Tillitt and others, 1991) and allowed to proliferate for $24 \mathrm{~h}$. The cells were then dosed with sample extracts or standards in isooctane and incubated for $72 \mathrm{~h}$ to allow for maximal EROD induction. A standardized TCDD solution was used to generate an analytical dose-response curve, and a total of six dose-response curves were analyzed on each assay date. A linear regression was performed on each sample well to obtain the slope and estimate the rate of the reaction ( $\mathrm{pmol} / \mathrm{min}$ ). The amount of protein in each well was determined by the fluorescamine assay (Lorenzen and Kennedy, 1993), and the protein values were used to normalize dose to each well and EROD activity. The reaction rate observed in each well was normalized according to the measured protein content, generating a value of specific activity (pmols resorufin formed/minute/mg of protein). The reaction rate in each well was then divided by the measured dose given to each well (gram equivalents $/ \mathrm{mg}$ ) to result in specific activity per min per gram equivalent (g.eq.) dosed. Reported results are the average of four replicate concentrate doses. The mean EROD reaction rate ( $\mathrm{pmol} / \mathrm{min} /$ g.eq.) was divided by the average initial slope obtained for the TCDD standard curves, resulting in a measure of an equivalent dose of TCDD (TCDD-EQ; pg/g) for each sample. Assay LODs ranged from 0.1 to $0.8 \mathrm{pg} / \mathrm{g}$, and the limits of quantification (LOQs) ranged from 0.5 to $1.7 \mathrm{pg} / \mathrm{g}$.

\section{EROD Activity}

Cryogenically frozen liver samples were stored at $-80^{\circ} \mathrm{C}$ by CERC until the preparation of microsomal fractions, which were used the same day they were prepared. The kinetic microsomal assays were conducted in 96-well microtiter plates (Whyte and others, 2000). Briefly, triplicate determinations of EROD activity were performed on $10 \mu \mathrm{L}$ portions of each microsomal preparation, and mean EROD activity was 
reported. Protein content was determined using the fluorescamine protein assay (Lorenzen and Kennedy, 1993) in the same 96-well microtiter plate as the EROD analyses. A positive control material, liver microsomes of male Spague Dawley rats injected with $500 \mathrm{mg} / \mathrm{kg}$ of Aroclor 1254, was also analyzed. A linear regression was performed on the data from each well to determine an EROD rate ( $\mathrm{pmol} / \mathrm{min}$ ) along with its associated estimate of variance. Protein content was used to normalize EROD activity ( $\mathrm{pmol} / \mathrm{min} / \mathrm{mg}$ ) in each well. The LOD was calculated by adding the average basal EROD rate to three times the standard deviation of that rate, and the LOQ was calculated by adding the average basal EROD rate to ten times the standard deviation of that rate. LODs ranged from 0.01 to $0.23 \mathrm{pmol} / \mathrm{min} / \mathrm{mg}$, and the LOQs ranged from 0.12 to $0.87 \mathrm{pmol} / \mathrm{min} / \mathrm{mg}$.

\section{Fish Health Indicators}

\section{General Histopathological Analyses}

Tissues preserved in $10 \%$ NBF (liver, kidney, spleen, gill, gonad, and grossly visible lesions) were shipped to the LSC (Leetown, West Virginia) and Colorado Histo-Prep (Fort Collins, Colorado) and prepared for routine histopathological analysis (Blazer and others, 2002). Tissue sections (5 to 6- $\mu \mathrm{m}$, on glass slides) were stained with hematoxylin and eosin ( $\mathrm{H} \&$ E) for light microscopic examination.

\section{Quantitative Organism-Level Indicators}

The prevalence of gross external pathological disorders was determined with a rating of present (1) or absent (0) deduced from field data. Gross pathologies were selected for consistency with other monitoring programs that have used this type of assessment (Fournie and others, 1996). Gross abnormalities included grossly visible disorders of the eye (exophthalmia, hemorrhage, opacity, emboli, missing), opercles (shortening, deformities, parasites), and body surface (ulcers, parasites, discolored areas or raised growths). In addition, disorders of the fins and skeleton were included. Numerical values were assigned to internal and external observations of lesions recorded in the field, and a necropsy-based fish health assessment index (HAI) score was calculated for each fish by summing these values for all organs (Blazer and others, 2002). An index was only computed for a fish if there was a complete assessment.

Body and organ weights measured in the field were used to calculate condition and organosomatic indices. Condition factor was computed as body weight $(\mathrm{g}) / \mathrm{length}^{3}(\mathrm{~cm})$. The HSI was calculated as liver weight/(total body weight - gonad weight) X 100. Similarly, the SSI was calculated as spleen weight/(total body weight - gonad weight) X 100. Subtracting the weight of the gonads from the body weight in the computation of HSI and SSI minimizes the effect of the reproductive cycle on these indices (Dethloff and Schmitt, 2000). GSI was calculated as gonad weight/total body weight X 100. Additional information on these indices is given by Blazer and others (2002) and Dethloff and Schmitt (2000).

\section{Macrophage Aggregates}

Macrophage aggregates were quantified using two methods, manual digitized analysis and computer-based image analysis, and then the data were compared. For the manual digitized analysis, MAs in splenic tissues from Stations 312, $315,319,320$, and 324 were visualized with $\mathrm{H} \& \mathrm{E}$ and quantified by viewing multiple fields $(n=5)$ using a $10 \mathrm{X}$ eyepiece and a 20X objective. The total viewed area was $3.2 \mathrm{~mm}^{2}$ per spleen section. For the computer-based image analysis, MAs in splenic tissues from Stations 311, 313, 314, 316, 317, 321, 322,323 , and 325 were visualized through the Perl's method staining procedure, which enhance the pigments in the MAs (Luna, 1992). The total viewed area was $2 \mathrm{~mm}^{2}$ per spleen section. Bass and channel catfish from Stations 312 and 315 were analyzed using both methods. MA measurements included the number of aggregates in a $\mathrm{mm}^{2}$ of tissue (MA-\#) and the area of each aggregate (MA-A). The percentage of tissue occupied by MA (MA-\%) was computed from these measurements (Blazer and others, 2002).

\section{Reproductive Biomarkers}

\section{Gonadal Histopathology}

Tissue pieces representing the entire gonad length were preserved in $10 \%$ NBF. Transverse sections were processed for routine light microscopy (embedded in paraffin, sectioned at 5 to $6 \mu \mathrm{m}$, and stained with $\mathrm{H} \& \mathrm{E}$ ).

Female gonadal tissue was staged using developmental stages (designated 0-5) to classify each section (Blazer, 2002; McDonald and others, 2002; Nagahama, 1983; Rodriguez and others, 1995; Treasurer and Holliday, 1981). Fish ovaries typically contain oocytes in several developmental stages and were classified according to the maturity of the predominant stage of oogenesis in each tissue sample. Ovaries containing only undeveloped, previtellogenic oocytes were assigned to stage 0 (immature). Samples containing only previtellogenic chromatin nucleoli and perinuclear oocytes, identified by cytoplasm that stained basophilic with $\mathrm{H} \& \mathrm{E}$, were assigned to stage 1 (previtellogenic). Ovaries containing previtellogenic oocytes as in stage 1 plus some cortical alveoli oocytes were classified as stage 2 (early vitellogenic). Those containing larger oocytes in which the cortical alveoli were pushed to the periphery of the cell, yolk globules filled the center, and the chorion of the developing oocytes were thicker than in earlier stages were designated as stage 3 (mid-vitellogenic). Ovaries containing oocytes with fused yolk globules were designated as stage 4 (late vitellogenic). Ovaries containing 
post-ovulatory follicles, which can be observed for some time after ovulation, are typically assigned to stage 5 (spent). After the ovarian tissues were staged they were further examined by light microscopy for atresia and other abnormalities. One hundred oocytes in each fish sample were counted when possible. Those showing morphological evidence of resorption or necrosis were quantified, and the percent of atretic oocytes were calculated. Oocyte atresia data in fish from Stations $312,315,319,320$, and 324 were categorized and were not included in the statistical analyses or figures but are presented in the tables.

Analogous to the procedure used to stage ovaries, male gonadal tissue was classified into developmental stages (0-4) according to the maturity of the predominant stage of spermatogenesis of each tissue sample (Blazer, 2002; Nagahama, 1983). Immature, undeveloped, or regressed testes containing only spermatogonia were classified as stage 0 (immature) where as those containing primarily spermatocytes and spermatids were designated as stage 1 (early spermatogenic). Stage-2 (mid-spermatogenic) testes contain approximately equal proportions of spermatocytes, spermatids, and spermatozoa, and testes containing primarily mature spermatozoa were identified as stage 3 (late spermatogenic). Stage-4 testes were identified as post-spawning or spent. Testicular tissue was also examined microscopically for any abnormalities such as intersex. Male fish were classified as intersex when individual or small foci of undeveloped oocytes were observed within testicular tissue (that is, when an ovotestis condition was detected).

\section{Vitellogenin}

Concentrations of plasma vtg were determined by direct Enzyme-Link Immunosorbent Assay (ELISA) using the monoclonal antibodies (mAb), 3G2, 2D4, 2C11, and $1 \mathrm{C} 8$ for the bass, carp, sucker, and trout, respectively. The plasma samples were diluted 1:200 (1:100 for carp), 1:10,000, $1: 100,000$ and $1: 1,000,000$ with $10 \mathrm{mM}$ phosphate, $150 \mathrm{mM}$ $\mathrm{NaCl}, 0.02 \%$ azide, $10 \mathrm{KIU} / \mathrm{mL}$ Aprotinin, pH 7.6 (PBSZAP). Species-specific vtg standards $(0,0.005,0.01,0.02$, $0.04,0.06,0.08,0.1,0.2,0.4,0.6,0.8,1.0 \mu \mathrm{g} / \mathrm{mL}$ ) containing 1:200, 1:10,000, 1:100,000, and 1:1,000,000 male plasma (in PBSZ-AP) were added to account for matrix effect (Denslow and others, 1999). Samples and standards were loaded onto a 96-well ELISA plate in triplicate and stored overnight at $4^{\circ} \mathrm{C}$ in a humidified container. The following day the plates were washed four times with PBSZ and then blocked with $1 \%$ BSA in $10 \mathrm{mM}$ tris, $150 \mathrm{mM} \mathrm{NaCl}, 0.05 \%$ tween, $0.02 \%$ azide, 10 KIU/mL Aprotinin, $\mathrm{pH} 7.6$ (1\% BSA/TBSTZ-AP) for $2 \mathrm{~h}$ at room temperature. The plates were rewashed with PBSZ (4 times) and the monoclonal antibody was loaded into wells on each plate. The lowest dilution (1:200) was probed with 1-3 $\mu \mathrm{g} / \mathrm{mL}$ of the $\mathrm{mAb}$ (depending on species) and dilutions of $1: 10 \mathrm{k}$ and higher with $0.1 \mu \mathrm{g} / \mathrm{mL}$. After the addition of the $\mathrm{mAb}$, the plates were stored at $4^{\circ} \mathrm{C}$ overnight in the humidified container. The following day the plates were washed and the biotinylated secondary antibody (goat anti mouse IgG-biotin) was added to each well at 1:1000 dilution in 1\% BSA/TBSTZ$\mathrm{AP}$ and incubated at room temperature for $2 \mathrm{~h}$. The plates were washed, and strepavidin-alkaline phosphatase was added at 1:1,000 dilution in 1\% BSA/TBSTZ-AP and incubated for $2 \mathrm{~h}$ at room temperature. After a final wash of the plates, the color was developed by adding $1 \mathrm{mg} / \mathrm{mL}$ p-nitro-phenyl phosphate in carbonate buffer $(0.03 \mathrm{M}$ carbonate, $2 \mathrm{mM}$ $\mathrm{MgCl}_{2}, \mathrm{pH}$ 9.6) and measuring the color using an ELISA plate reader (SpectraMax Plus384, Applied Biosystems) at $405 \mathrm{~nm}$. Concentrations of the unknowns were determined from the standard curves.

The LOD for the vtg direct ELISA was $0.001 \mathrm{mg} / \mathrm{mL}$ for bass, $0.0005 \mathrm{mg} / \mathrm{mL}$ for carp and sucker, and $0.002 \mathrm{mg} / \mathrm{mL}$ for trout. All assays were performed in triplicate and reported as the mean of the three measurements. The coefficient of variation was $<10 \%$ for all samples analyzed. Inter and intra-assay variability was routinely measured by analyzing controls on several plates and different runs was found to be $<10 \%$, and $<5 \%$, respectively.

\section{Sex Steroid Hormones}

Concentrations of 17 $\beta$-estradiol (E2) and 11-ketotestosterone (KT) in plasma samples collected from carp, bass, channel catfish, brown trout, white sucker, and flathead catfish were measured by radioimmunoassay (RIA). For analysis, samples were thawed and split. Duplicate plasma samples $(50 \mu \mathrm{L})$ were extracted twice by adding $4 \mathrm{~mL}$ of ethyl ether, vortexing for $1 \mathrm{~min}$, freezing the aqueous layer in a methanol-dry ice bath, and decanting the ether layer containing the lipophilic sex steroids. Standard curves were prepared in phosphate buffered saline with gelatin and azide (PBSGA) buffer using variable amounts of unlabeled E2 or KT $(1,5,10$, $25,50,100,250,500$ and 1,000 pg) and a constant concentration of radiolabeled hormone. Cross-reactivities of the E2 and KT antiserums with other steroids were low. Reactions were comprised of plasma extract $(50 \mu \mathrm{L})$, radiolabeled sex steroid hormone $(100 \mu \mathrm{L})$, and corresponding sex steroid hormonespecific antibody $(100 \mu \mathrm{L})$ in PBSGA buffer $(250 \mu \mathrm{L})$. The reaction solutions were allowed to equilibrate overnight, during which time the unlabeled hormone from the extract and a constant concentration of the corresponding radiolabeled sex steroid hormone competed for the same antibody binding sites. Following incubation, non-antibody bound radiolabeled hormone was removed by adding $250 \mu \mathrm{L}$ of charcoal dextran and centrifuging at 3,000 X g for $10 \mathrm{~min}$. Supernatant aliquots $(0.4 \mathrm{~mL})$ containing bound radiolabeled hormone were removed and placed in a vial with $4 \mathrm{~mL}$ of scintillation fluid. Radioactivity was measured using scintillation spectrophotometry. Sex steroid concentrations in plasma extracts were determined using a four-parameter logistics regression analysis of standard curves, which was then used to calculate concentrations for plasma extracts.

Pooled samples in triplicate were assayed serially in 10-, 20-, 30-, 40-, and 50- $\mu \mathrm{l}$ volumes (final volume of $50 \mu \mathrm{l}$ with 
charcoal-stripped plasma). The resulting inhibition curves were parallel to the respective standard curve, with the tests for homogeneity of regression indicating that the curves did not differ. Further characterization of the assays involved measurement of known amounts (1, 2, 5, 10, 25, 50, 100, 250 and $500 \mathrm{pg}$ ) of E2 or KT in $50 \mu \mathrm{l}$ charcoal-stripped plasma. Hormone concentrations in the plasma samples were corrected for extraction efficiency of $90 \pm 5.2 \%$ for $\mathrm{E} 2$ and $86 \pm 7.0 \%$ for KT. The LOD was $10.7 \mathrm{pg} / \mathrm{mL}$ for E2 and $14.3 \mathrm{pg} / \mathrm{mL}$ for KT. Inter- and intra-assay coefficients of variation were $9.4 \%$ and $11.2 \%$, respectively, for E2 and $9.4 \%$ and $12.1 \%$, respectively, for $\mathrm{KT}$.

The ratio of $\mathrm{E} 2$ to $\mathrm{KT}$ (E/KT) is an additional variable used to analyze sex steroid hormones (Folmar and others, 1996; Goodbred and others, 1997; Hileman, 1994). Typically, E/KT ratio is $>1.0$ in female fish and $<1.0$ in male fish, but exact ranges of normality and seasonal fluctuations in this variable have not been established.

\section{Data Set Composition and Statistical Analyses}

Carp, bass, and channel catfish were included in the statistical analyses. For indicators based on individual fish (that is, biomarkers and demographic endpoints), data were discussed in terms of the magnitude of the means within a gender for different species. Data were summarized graphically with box plots presenting the mean, median, range, and 25 th and 75 th percentiles. Some biomarkers were also analyzed more rigorously (see following paragraphs).

Descriptive statistics were calculated for length, weight, and age data for species at individual stations. Fish for which otoliths, spines, or scales were unreadable for age determination ( 7 carp; 4 bass; 3 channel catfish; 3 white sucker; 1 flathead catfish) were not included in the presentation or analysis of age data. Gender was reported as NG (no gonad) for fish in which no gonad tissue was collected ( 3 carp; 3 channel catfish; 1 bass; 1 flathead catfish; 1 brown trout). Other biological data for carp, bass, and channel catfish are presented in tabular form and are discussed. Length and weights of carp, bass, and channel catfish were also analyzed statistically because of the influence of fish size on concentrations of $\mathrm{Hg}$.

A total of 52 composite samples from 14 stations were analyzed for chemical contaminants in fish tissue. Twenty six samples (50\%) from 13 stations were carp, 12 samples $(23 \%)$ from six stations were bass, 10 samples (19\%) from five stations were channel catfish, two samples $(4 \%)$ from one station were brown trout, and two samples (4\%) from one station were white sucker. All results for composite samples were converted to, analyzed statistically as, and reported as ww concentrations. A value of one-half the LOD was substituted for censored values (that is, values $<$ LOD) in the computation of un-weighted geometric station means and for statistical analyses and censored values in all graphs (Schmitt and others, 1999).
Concentrations of many contaminants were $<\mathrm{LOD}$, which precluded rigorous statistical analysis. Tissue concentration data are presented graphically and as tabular summaries. Geographic differences in contaminant concentrations were also examined statistically using ANOVA. Log-transformed concentrations of these analytes in carp, bass, and channel catfish were analyzed with series of $t$-tests using a pooled error mean-square $\left(\mathrm{MS}_{\mathrm{e}}\right)$ representing differences between- or among-samples of the same species. A nominal $\alpha$-level of 0.01 was used in these comparisons to protect against experiment-wise error. Because concentrations of $\mathrm{Hg}$ in predatory fish increase with size, age, or both (for example, Wiener and others, 2002), log-transformed length-adjusted ( $\mathrm{HgL})$ and weight-adjusted ( $\mathrm{HgW})$ concentrations were also tested using this procedure. Following the method of Brumbaugh and others (2001), the adjusted $\mathrm{Hg}$ values were computed by dividing the measured concentration in each composite sample by the mean length $(\mathrm{m})$ and weight $(\mathrm{kg})$ of the individual fish comprised by the sample. Unadjusted $\mathrm{Hg}, \mathrm{HgW}$, and $\mathrm{HgL}$ were also analyzed separately using the one-way analysis, which resulted in a more conservative test with fewer degrees-offreedom and $\mathrm{MS}_{\mathrm{e}}$-values based on only one species. Toxicity thresholds and contaminant concentration data from other studies were converted to ww concentrations, assuming $75 \%$ moisture, if the original study documented concentrations in $\mathrm{dw}$ and percent moisture was not reported.

Biomarkers can differ among species, gender, age, and reproductive stage (Schmitt, 2002; Schmitt and Dethloff, 2000). Accordingly, a series of linear ANOVA models were fit to the individual fish data for carp, bass, and channel catfish to determine which factors influenced biomarker responses in these taxa. Analyses conducted on larger, previous LRMN datasets were used as a guide. The results of these analyses were reported as $F$-values and significance levels and were used to guide the graphical presentation and discussion of the findings. Because of the complexity of the models and the small size of the data set, the means could not be adjusted for the factors in the models. Data are presented and discussed in terms of the magnitudes of the means for combined genders or each gender within a species and at different stations within a species. Some individual points are also discussed. Data are presented graphically and summarized as described for the demographic data.

\section{Results and Discussion}

\section{Geographic Distribution and Demographic Characteristics of the Fish Collected}

A total of 517 fish representing seven species were collected (table 6). Carp, bass, and channel catfish accounted for $90 \%$ of the fish obtained. Carp were collected from all 14 stations, largemouth bass and channel catfish from six stations, 
Table 6. Number of fish collected, organized by station, species, and gender, in the Colorado River Basin in 2003. Stations are grouped by sub-basin and listed upstream to downstream. Station numbers are given in parentheses. Species totals that include individual(s) of unknown gender are designated by an asterisk $(*)$.

\begin{tabular}{|c|c|c|c|c|}
\hline Sub-basin, station and species & Male & Female & Species total & Station total \\
\hline \multicolumn{5}{|l|}{ Upper Colorado River Basin } \\
\hline Lay, CO (311) & & & & 40 \\
\hline Smallmouth bass & 10 & 9 & $20^{*}$ & \\
\hline White sucker & 8 & 11 & 19 & \\
\hline Carp & & & $1 *$ & \\
\hline Ouray NWR, UT (312) & & & & 45 \\
\hline Carp & 9 & 11 & 20 & \\
\hline Channel catfish & 6 & 5 & 11 & \\
\hline Smallmouth bass & 8 & 6 & 14 & \\
\hline San Rafael, UT (313) & & & & 39 \\
\hline Carp & 11 & 10 & 21 & \\
\hline Channel catfish & 14 & 4 & 18 & \\
\hline Delta, CO (314) & & & & 42 \\
\hline Brown trout & 9 & 11 & $21^{*}$ & \\
\hline Carp & 8 & 13 & 21 & \\
\hline Loma, CO (315) & & & & 37 \\
\hline Carp & 10 & 10 & 20 & \\
\hline Channel catfish & 1 & 2 & $5^{*}$ & \\
\hline Largemouth bass & 7 & 5 & 12 & \\
\hline Gold Bar Canyon, UT (316) & & & & 40 \\
\hline Carp & 10 & 10 & 20 & \\
\hline Channel catfish & 10 & 10 & 20 & \\
\hline Hogback Diversion, NM (317) & & & & 40 \\
\hline Carp & 13 & 7 & 20 & \\
\hline Channel catfish & 8 & 11 & $20^{*}$ & \\
\hline \multicolumn{5}{|l|}{ Lower Colorado River Basin } \\
\hline South Cove, AZ (319) & & & & 17 \\
\hline Carp & 6 & 11 & 17 & \\
\hline Willow Beach, AZ (320) & & & & 20 \\
\hline Carp & 11 & 8 & $20^{*}$ & \\
\hline Needles, CA (321) & & & & 40 \\
\hline Carp & 8 & 12 & 20 & \\
\hline Largemouth bass & 9 & 11 & 20 & \\
\hline Imperial Dam, AZ (322) & & & & 40 \\
\hline Carp & 8 & 12 & 20 & \\
\hline Largemouth bass & 10 & 10 & 20 & \\
\hline Hayden, AZ (323) & & & & 40 \\
\hline Carp & 13 & 7 & 20 & \\
\hline Flathead catfish & 7 & 3 & $11^{*}$ & \\
\hline Largemouth bass & 5 & 4 & 9 & \\
\hline Phoenix, AZ (324) & & & & 37 \\
\hline Carp & 10 & 8 & $20^{*}$ & \\
\hline Channel catfish & 2 & 12 & $15^{*}$ & \\
\hline Largemouth bass & 2 & & 2 & \\
\hline Arlington, AZ (325) & & & & 40 \\
\hline Carp & 7 & 13 & 20 & \\
\hline Largemouth bass & 9 & 11 & 20 & \\
\hline
\end{tabular}


smallmouth bass from two stations, and white sucker, brown trout, and flathead catfish from one station each (table 6). Only carp were captured from Stations 319 and 320 although attempts were made to collect predatory species at these stations. Bass or channel catfish were collected from all stations except Station 314 where brown trout was the predator species.

Total length, weight, and age were examined in CDRB carp. The mean total length (TL) of carp was $477 \mathrm{~mm}$, the mean weight was $1,365 \mathrm{~g}$, and the mean age was $18.9 \mathrm{y}$ (table 7). Female and male carp were similar in length, weight, and age (table 7). Carp were generally smallest (mean TL and weight) from Station 325 and largest from Station 314 (table 7). Age varied among stations with carp from the GRB (Stations 323, 324, and 325) being younger ( $<10 \mathrm{y})$ than those from other stations ( $>20 \mathrm{y}$ ). CDRB carp were slightly smaller but older than carp collected in previous LRMN studies (Hinck and others, 2004a; Schmitt, 2002; Schmitt and others, 2004). Carp from previous LRMN investigations were younger $(<15 \mathrm{y})$ than CDRB carp although previous age estimates were based on scales (Hinck and others, 2004a; Schmitt, 2002; Schmitt and others, 2004). Age was estimated from otoliths (asterisci) in CDRB carp and verified by two independent laboratories. Otoliths have been used to age carp in other studies, but the use of otoliths to estimate age in carp has not been validated for fish $>14$ years old (Brown and others, 2004b; Vilizzi and Walker, 1999; Wilde and Pope, 2002). A previous study in Lake Mead using whole otoliths to age fish estimated carp to be 1-3 y (Wilde and Pope, 2002), but conditions in the CDRB are favorable for carp to be $>20$ y (D. Scarnecchio, oral communication). Carp, which were introduced to the CDRB prior to the 1880 s, have no natural predators in the basin and can successfully spawn in vegetated areas with slow current. Carp may be younger in the GRB due to intermittent water flows during the year. The age of some CDRB carp may have been overestimated if otolith rings represented changes in water temperature, periods of rapid growth, or lunar cycles rather than annual growth. More information is needed to determine if otoliths are the appropriate structures to estimate age in carp.

Total length, weight, and age varied in CDRB bass. The mean TL of bass was $348 \mathrm{~mm}$, and mean weight was $597 \mathrm{~g}$ (table 8). The mean age bass was 3.3 y. Female bass outweighed male bass (676 g vs. $529 \mathrm{~g}$ ) and were longer $(365 \mathrm{~mm}$ vs. $334 \mathrm{~mm}$ ), but the average age for both females and males was similar (3.6 y vs. 3.1 y). The largest female and male bass (mean TL and weight) were from Station 321, and the smallest bass were from Station 323 (table 8). Bass were older from Stations 311, 315, and 321 than from other CDRB stations. Smallmouth bass from Stations 311 and 312 were similar in size to largemouth bass collected from other CDRB stations (table 8). The average lengths, weights, and ages of CDRB bass were similar to bass collected in previous LRMN studies (Hinck and others, 2004a; Schmitt, 2002; Schmitt and others, 2004).
Total length, weight, and age varied in female and male CDRB channel catfish. In channel catfish, mean TL was 389 $\mathrm{mm}$ in TL and mean weight was $593 \mathrm{~g}$ (table 9). Female channel catfish were slightly larger than males (table 9). The mean age for channel catfish was $6.5 \mathrm{y}$ (range 1-15 y), and female and male ages were similar (6.6 y vs. 6.2 y). Channel catfish from Stations 312, 313, and 316 were smaller (mean TL and weight) than those from Stations 315, 317, and 324 (table $9)$. The youngest channel catfish were collected from Station 324 (<3 y) while those from Station 315 were the oldest $(>9$ y). Length, weight, and age data for the other species are in Appendix 4.

\section{Accumulative contaminants, H4IIE Bioassay, and EROD Activity}

\section{Elemental Contaminants}

\section{Arsenic}

Arsenic was detected in all CDRB samples, and the greatest concentrations $(>0.14 \mu \mathrm{g} / \mathrm{g})$ were measured in carp from Stations 319, 320, 321, 322, and 323 (fig. 4; table 10). The greatest concentration $(0.19 \mu \mathrm{g} / \mathrm{g})$ was measured in male carp from Station 320, and the greatest mean concentration $(0.17$ $\mu \mathrm{g} / \mathrm{g}$ ) was also measured at this site (table 11). Concentrations of As in other species were generally $<0.10 \mu \mathrm{g} / \mathrm{g}$ (fig. 4). Arsenic concentrations differed significantly among CDRB stations in carp but not in bass or channel catfish (table 12). Arsenic concentrations were significantly greater in carp from Stations 319, 320, 321, 322, and 323 in the Lower CDRB than carp from Stations 314, 316, and 317 in the Upper CDRB.

Concentrations of As in 2003 samples were similar to those documented in other CDRB studies. The maximum NCBP concentrations of As in the CDRB were $0.33 \mu \mathrm{g} / \mathrm{g}$ in carp, $0.49 \mu \mathrm{g} / \mathrm{g}$ in bass, and $0.29 \mu \mathrm{g} / \mathrm{g}$ in channel catfish from 1971 to 1986 (Schmitt and others, 1999). Historical NCBP concentrations in carp and channel catfish were similar to those measured in 2003. Concentrations in bass near Stations $319,320,321$, and 322 were generally greater $(>0.15 \mu \mathrm{g} / \mathrm{g})$ in NCBP samples than in 2003 samples. Arsenic concentrations were lower $(<0.08 \mu \mathrm{g} / \mathrm{g})$ in whole-body carp collected near Stations 321 and 322 in conjunction with a 1986 NIWQP investigation (Radtke and others, 1988) than those in 2003 carp samples. Butler and others (1996) reported that most As concentrations in fish were $<0.27 \mu \mathrm{g} / \mathrm{g}$ in western Colorado, and concentrations were $0.04-0.16 \mu \mathrm{g} / \mathrm{g}$ in carp and 0.07-0.14 $\mu \mathrm{g} / \mathrm{g}$ in white sucker from the Ouray NWR (Station 312) in 1991-1993 (Rowland and others, 2002). Relatively high As concentrations were also measured in liver of bluehead sucker (Catostomus discobolus) from the CDR near Cameo and Loma, Colorado (near Station 315; Deacon and Stephens, 1998). 


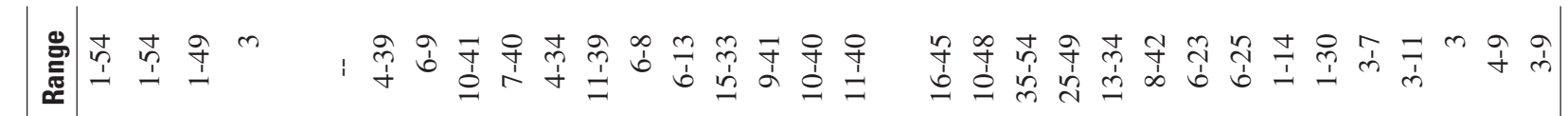

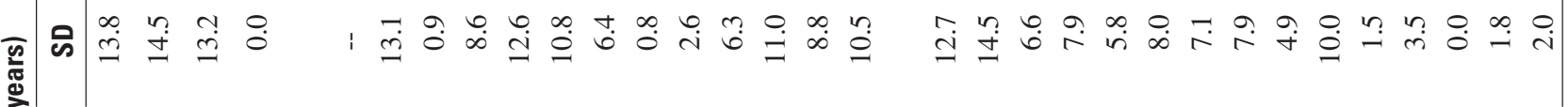

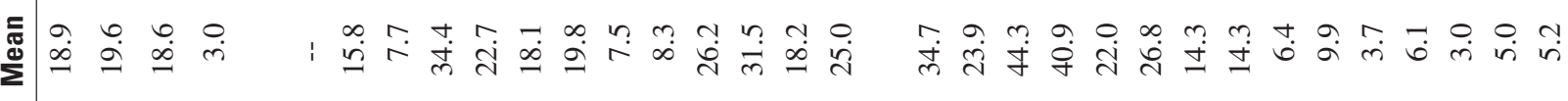

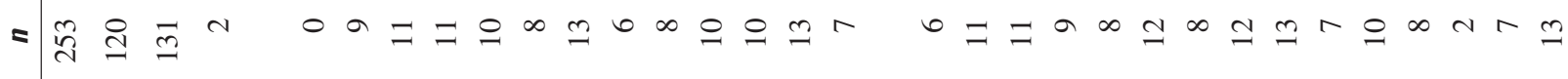

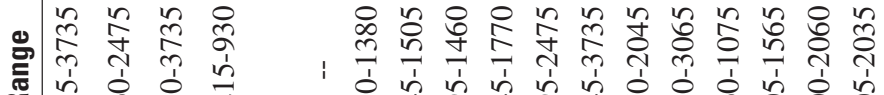

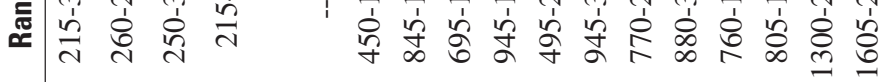

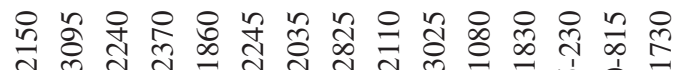

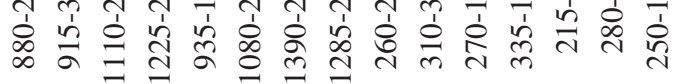

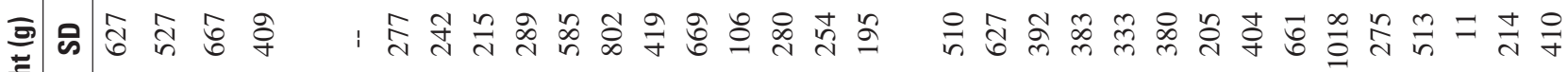

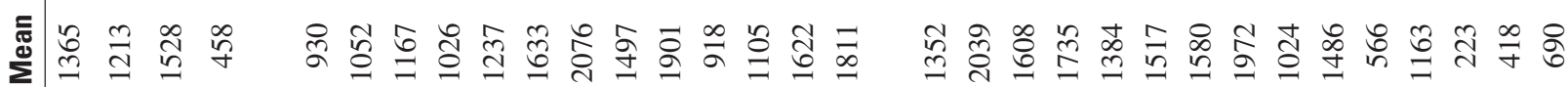

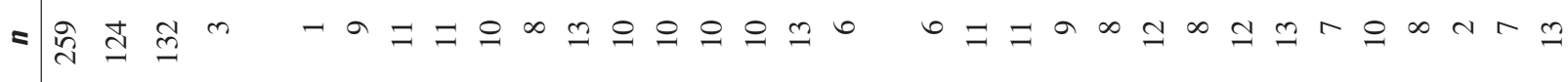

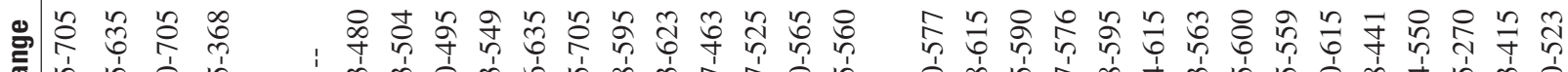

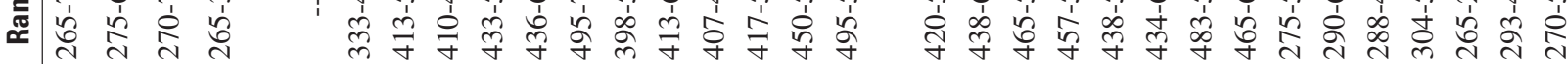

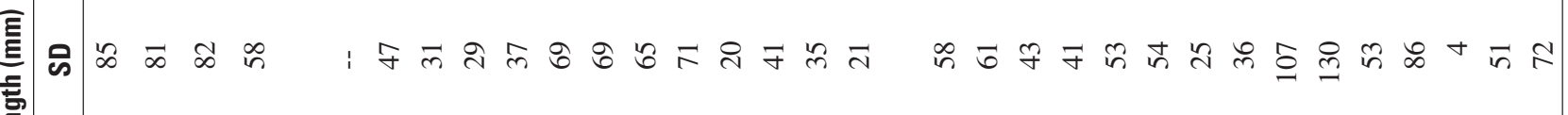

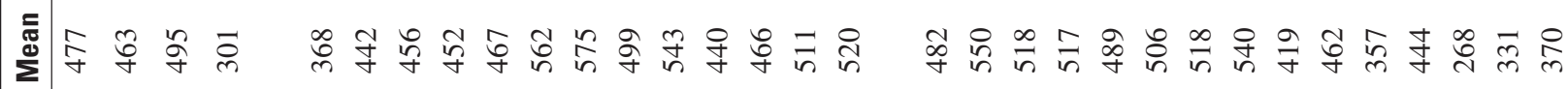

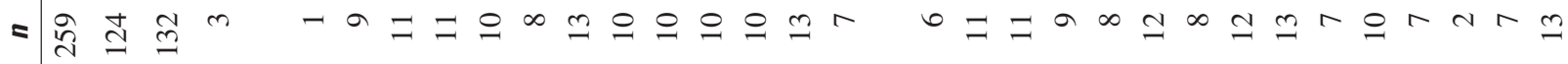
ॠ

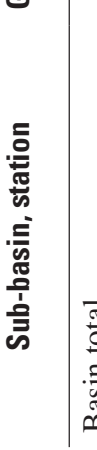

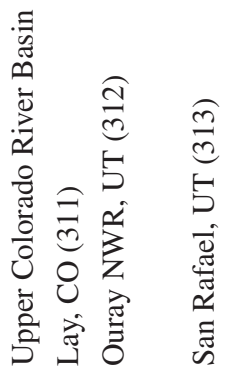

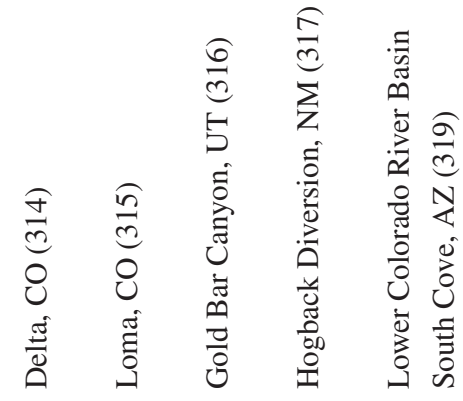

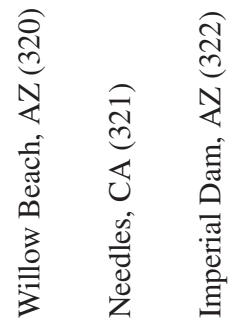

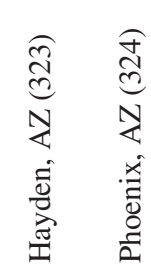

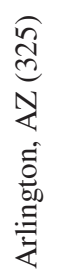




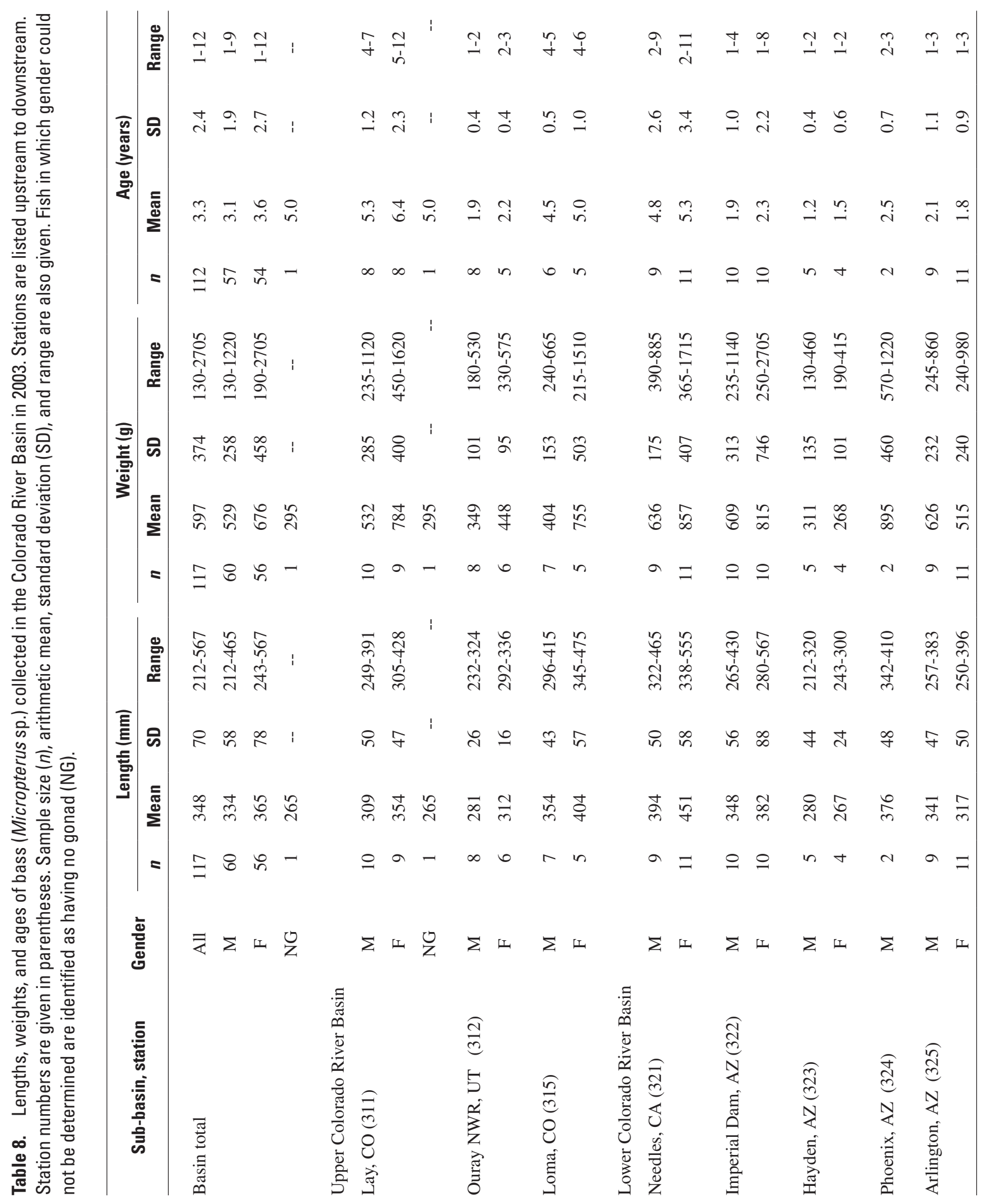


Table 9. Lengths, weights, and ages of channel catfish (/ctalurus punctatus) collected in the Colorado River Basin in 2003. Stations are listed upstream to downstream. Station numbers are given in parentheses. Sample size (n), arithmetic mean, standard deviation (SD), and range are also given. Fish in which gender could not be determined are identified as having no gonad (NG).

\begin{tabular}{|c|c|c|c|c|c|c|c|c|c|c|c|c|c|}
\hline \multirow{2}{*}{ Sub-basin, station } & \multirow{2}{*}{ Gender } & \multicolumn{4}{|c|}{ Length (mm) } & \multicolumn{4}{|c|}{ Weight (g) } & \multicolumn{4}{|c|}{ Age (years) } \\
\hline & & $n$ & Mean & SD & Range & $n$ & Mean & SD & Range & $n$ & Mean & SD & Range \\
\hline \multirow[t]{4}{*}{ Basin total } & All & 88 & 389 & 96 & $234-685$ & 88 & 593 & 553 & $90-3210$ & 86 & 6.5 & 3.0 & $1-15$ \\
\hline & $\mathrm{F}$ & 44 & 399 & 98 & $234-685$ & 44 & 655 & 627 & $90-3210$ & 43 & 6.6 & 3.6 & $1-15$ \\
\hline & M & 42 & 370 & 90 & $247-620$ & 41 & 510 & 475 & $110-2275$ & 41 & 6.2 & 2.3 & $2-12$ \\
\hline & NG & 3 & 501 & 72 & $440-580$ & 3 & 807 & 163 & $665-985$ & 2 & 8.5 & 0.7 & $8-9$ \\
\hline \multicolumn{14}{|l|}{ Upper Colorado River Basin } \\
\hline \multirow[t]{2}{*}{ Ouray NWR, UT (312) } & M & 6 & 308 & 26 & $279-345$ & 6 & 209 & 65 & $140-290$ & 6 & 6.7 & 1.6 & $5-9$ \\
\hline & $\mathrm{F}$ & 5 & 323 & 49 & $279-390$ & 5 & 255 & 130 & $155-400$ & 5 & 8.8 & 1.9 & $6-11$ \\
\hline \multirow[t]{2}{*}{ San Rafael, UT (313) } & M & 14 & 338 & 64 & $247-430$ & 14 & 360 & 220 & $110-690$ & 14 & 5.7 & 1.9 & $3-10$ \\
\hline & $\mathrm{F}$ & 4 & 320 & 27 & $289-346$ & 4 & 210 & 51 & $175-285$ & 4 & 5.0 & 1.2 & $4-6$ \\
\hline \multirow[t]{3}{*}{ Loma, CO (315) } & M & 1 & 488 & -- & -- & 1 & 1230 & -- & -- & 0 & -- & -- & -- \\
\hline & $\mathrm{F}$ & 2 & 485 & 29 & $464-505$ & 2 & 713 & 131 & $620-805$ & 1 & 15.0 & -- & -- \\
\hline & NG & 2 & 531 & 69 & $482-580$ & 2 & 878 & 152 & $770-985$ & 1 & 9.0 & -- & -- \\
\hline \multirow[t]{2}{*}{ Gold Bar Canyon, UT (316) } & M & 10 & 328 & 39 & 270-399 & 10 & 256 & 114 & $135-520$ & 10 & 6.2 & 2.5 & $3-11$ \\
\hline & $\mathrm{F}$ & 10 & 332 & 58 & $234-420$ & 10 & 272 & 162 & $90-590$ & 10 & 6.3 & 1.6 & $4-10$ \\
\hline \multirow[t]{3}{*}{ Hogback Diversion, NM (317) } & M & 8 & 460 & 69 & $375-600$ & 8 & 888 & 402 & $480-1760$ & 8 & 8.1 & 2.1 & $6-12$ \\
\hline & $\mathrm{F}$ & 11 & 453 & 47 & $400-555$ & 11 & 875 & 354 & $565-1790$ & 11 & 10.0 & 2.5 & $7-15$ \\
\hline & NG & 1 & 440 & -- & -- & 1 & 665 & -- & -- & 1 & 8.0 & -- & -- \\
\hline \multicolumn{14}{|l|}{ Lower Colorado River Basin } \\
\hline \multirow[t]{2}{*}{ Phoenix, AZ (324) } & M & 3 & 493 & 84 & $335-620$ & 2 & 1855 & 594 & $1435-2275$ & 3 & 2.7 & 0.6 & $2-3$ \\
\hline & $\mathrm{F}$ & 12 & 450 & 125 & $290-685$ & 12 & 1079 & 934 & $205-3210$ & 12 & 2.8 & 1.4 & $1-5$ \\
\hline
\end{tabular}

Multiple USFWS studies have documented As concentrations in CDRB fish. In 1994 and 1995, King and others (1997) measured As in whole-body carp $(<0.05-0.89 \mu \mathrm{g} / \mathrm{g})$, largemouth bass $(0.39-0.85 \mu \mathrm{g} / \mathrm{g})$, and channel catfish $(0.06-$ $0.46 \mu \mathrm{g} / \mathrm{g}$ ) in the cotton growing regions of the Lower GRB near Stations 324 and 325. Concentrations were 0.07-0.13 $\mu \mathrm{g} / \mathrm{g}$ in channel catfish from the Lower GRB and Yuma Valley (Baker and others, 1992). Arsenic in fish from Imperial, Cibola, and Havasu NWRs did not represent a threat to piscivorous wildlife in the late 1980s (King and others, 1993), but Andrews and others (1997) concluded that concentrations $(<0.10-0.20 \mu \mathrm{g} / \mathrm{g})$ in fish from the Havasu NWR may represent a risk to fish and wildlife. Concentrations of As in fish collected in the Middle GR from Coolidge Dam to AshurstHayden Dam (near Station 323) ranged from $<0.05 \mu \mathrm{g} / \mathrm{g}$ to $1.11 \mu \mathrm{g} / \mathrm{g}$ and have the potential to harm wildlife in some areas (Andrews and King, 1997).

Concentrations of As in carp, bass, and channel catfish were measured in previous LRMN studies. Concentrations in carp ranged from 0.12 to $0.32 \mu \mathrm{g} / \mathrm{g}$ in the MRB (Schmitt and others, 2002), 0.05 to $0.55 \mu \mathrm{g} / \mathrm{g}$ in the RGB (Schmitt and others, 2004), and 0.24 to $0.56 \mu \mathrm{g} / \mathrm{g}$ in the CRB (Hinck and others, 2004a). In bass, As concentrations were 0.10-0.57 $\mu \mathrm{g} / \mathrm{g}$ in the MRB (Schmitt and others, 2002), 0.04-0.25 $\mu \mathrm{g} / \mathrm{g}$ in the RGB (Schmitt and others, 2004), and 0.22-0.53 $\mu \mathrm{g} / \mathrm{g}$ in the CRB (Hinck and others, 2004a). Concentrations of As in channel catfish ranged from 0.05 to $0.23 \mu \mathrm{g} / \mathrm{g}$ in the RGB (Schmitt and others, 2004). Overall, As concentrations in CDRB fish $(0.01-0.19 \mu \mathrm{g} / \mathrm{g})$ were less than those from other LRMN studies (table 13).

Arsenic concentrations in CDRB fish $(0.01-0.19 \mu \mathrm{g} / \mathrm{g})$ were not considered a hazard to the fish or piscivorous wildlife (USEPA, 1984). A review by Jarvinen and Ankley (1999) included several laboratory studies in which As effects were evaluated relative to whole-body concentrations. Concentrations of 8.1-13.5 $\mu \mathrm{g} / \mathrm{g}$ were associated with loss of equilibrium and $5.4 \mu \mathrm{g} / \mathrm{g}$ caused increased mortality in rainbow trout fingerlings (McGreachy and Dixon, 1990, 1992). Adult bluegill experienced reduced survival and growth at $11.6 \mu \mathrm{g} / \mathrm{g}$ (Gilderhus, 1966). Concentrations of As in all CDRB fish were 


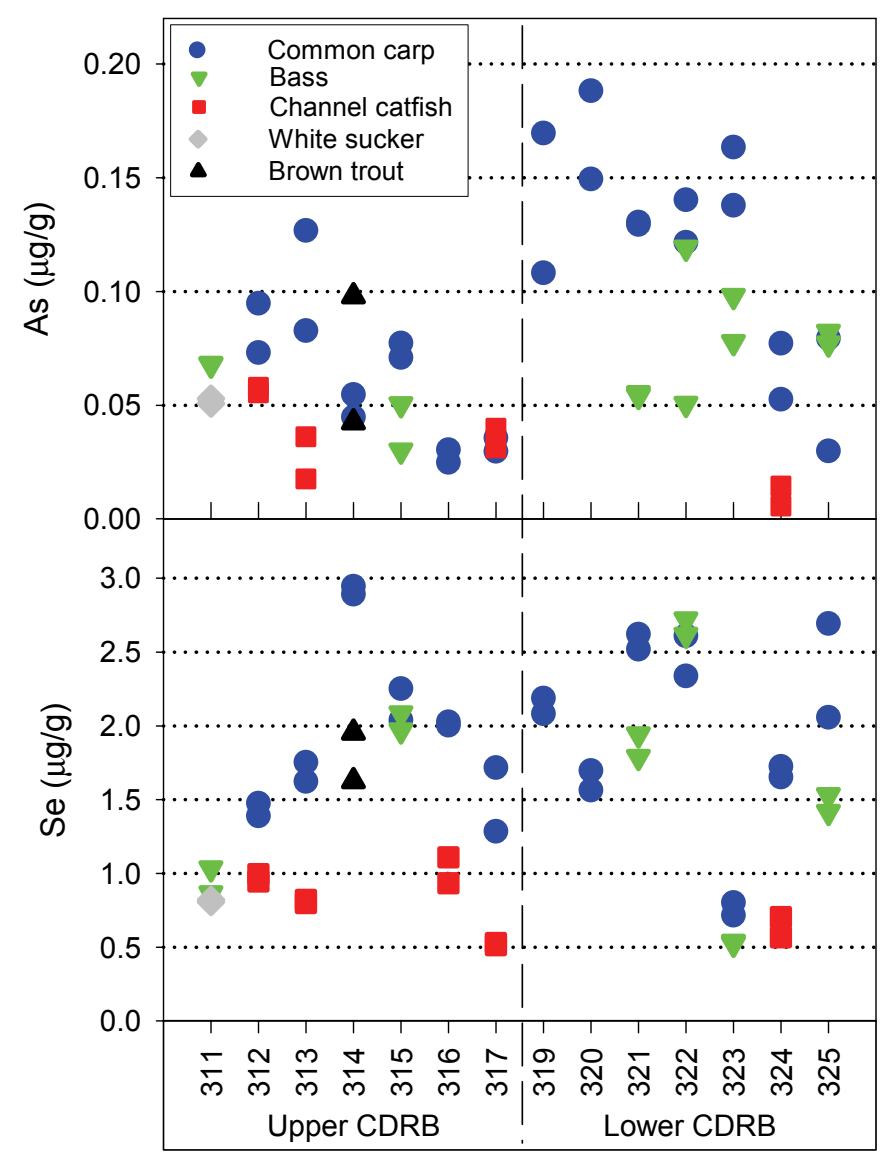

Station

Figure 4. Concentrations ( $\mu \mathrm{g} / \mathrm{g} \mathrm{ww}$ ) of arsenic (As) and selenium (Se) by station and taxon in whole-body fish composite samples from the Colorado River Basin in 2003. Censored values are plotted as one half the LOD. Stations are ordered from upstream to downstream and are grouped by sub-basin. See Table 2 for station descriptions.

below these thresholds and were not expected to adversely affect fish or wildlife in the basin.

\section{Selenium}

Selenium was detected in all samples, and the greatest concentration $(2.95 \mu \mathrm{g} / \mathrm{g})$ was measured in male carp from Station 314 (table 10). Concentrations were $>1.0 \mu \mathrm{g} / \mathrm{g}$ in most samples except those from Stations 311 and 323 (fig. 4). The greatest station mean $(2.57 \mu \mathrm{g} / \mathrm{g})$ was measured at Station 322 (table 11). Concentrations of Se were generally greatest in carp and bass and lowest in channel catfish (fig. 4). Selenium concentrations differed significantly among sites in carp, bass, and channel catfish (table 12). Concentrations in carp from Stations 314, 315, and 316 in the Upper CDR, Station 319 near Lake Mead, Stations 321 and 322 in the Lower CDR, and Station 325 in the Lower GR were significantly greater than those from other stations. Similarly, concentrations in bass from Stations 315, 321, 322, and 325 were significantly greater than those from Stations 311 and 323. Concentrations were significantly greater in channel catfish from Stations 312 and 316 than those from Station 317.

Relatively high Se concentrations have been measured historically in CDRB fish as a result of natural weathering of seleniferous shales, irrigation practices, uranium ore and coal extraction, and combustion of coal at hydroelectric generating stations (Radtke and others, 1988). Elevated concentrations in the Lower CDR are the result of transportation from the Upper CDR rather than local agricultural practices (Welsh and Maughan, 1994). Relatively high concentrations in carp (0.36$3.65 \mu \mathrm{g} / \mathrm{g})$, bass $(0.23-3.00 \mu \mathrm{g} / \mathrm{g})$, and channel catfish $(<0.05-$ $2.50 \mu \mathrm{g} / \mathrm{g}$ ) near Stations 312, 319, 320, 321, 322, and 323 were measured by the NCBP from 1971 to 1986 (Schmitt and others, 1999). Historical concentrations were generally lowest in carp and bass in the GR near San Carlos Reservoir (Station 323; Schmitt and others, 1999). Selenium concentrations in carp were $1.6 \mu \mathrm{g} / \mathrm{g}$ near Station 321 and $2.5 \mu \mathrm{g} / \mathrm{g}$ upstream Station 322 (Radtke and others, 1988), which are similar to 2003 concentrations at these stations. Butler and others (1996) reported concentrations $>0.73 \mu \mathrm{g} / \mathrm{g}$ (assuming $75 \%$ moisture) in fish from western Colorado, and concentrations in carp $(1.52-22.0 \mu \mathrm{g} / \mathrm{g})$ and white sucker $(0.71-16.0 \mu \mathrm{g} / \mathrm{g})$ were high in the Ouray NWR where selenium remediation efforts had been initiated (Rowland and others, 2002). Concentrations of Se were generally lower and below toxicity thresholds in most fish from the GRB (Andrews and King, 1997; Baker and others, 1992; King and others, 1997) compared to other CDRB fish. However, Se concentrations in fish from NWRs in the Lower CDR were elevated and may threaten fish reproduction (King and others, 1993) and piscivorous wildlife (Andrews and others, 1997).

Selenium concentrations in carp, bass, and channel catfish were measured in previous LRMN studies. Concentrations in carp were $<0.1-4.66 \mu \mathrm{g} / \mathrm{g}$ in the MRB (Schmitt and others, 2002), 0.23-1.54 $\mu \mathrm{g} / \mathrm{g}$ in the RGB (Schmitt and others, 2004), and 0.32-1.1 $\mu \mathrm{g} / \mathrm{g}$ in the CRB (Hinck and others, 2004a). In bass, concentrations were $0.21-4.46 \mu \mathrm{g} / \mathrm{g}$ in the MRB (Schmitt and others, 2002), 0.47-1.26 $\mu \mathrm{g} / \mathrm{g}$ in the RGB (Schmitt and others, 2004), and $<0.02-0.81 \mu \mathrm{g} / \mathrm{g}$ in the CRB (Hinck and others, 2004a). Selenium concentrations in channel catfish were 0.32-0.46 $\mu \mathrm{g} / \mathrm{g}$ in the RGB (Schmitt and others, 2004). Selenium concentrations in CDRB fish were greater than those measured in previous LRMN studies (table 13).

Several Se studies were included in a review by Jarvinen and Ankley (1999) on the effects of inorganic chemicals to aquatic organisms. Various studies from this review reported that whole-body concentrations of Se between 8 and 16 $\mu \mathrm{g} / \mathrm{g} \mathrm{dw}(2-4 \mu \mathrm{g} / \mathrm{g}$ ww assuming $75 \%$ moisture) have led to reproductive failure in fathead minnows (Pimephales promelas; Schultz and Hermanutz, 1990) and bluegill (Gillespie and Baumann, 1986; Hermanutz and others, 1992; Coyle and others, 1993). In addition, concentrations of Se present in the egg stage or at hatch affected larval survival (Coyle and others, 1993; Hamilton and others 2005b, 2005c), which 
Table 10. Percent of samples and stations that exceeded limit of detection (LOD) concentrations for elemental contaminants in composite samples of whole fish from the Colorado River Basin in 2003. The maximum concentrations and associated sample information (station, gender, and species) from this study are also given. NA, not applicable.

\begin{tabular}{|c|c|c|c|c|c|c|c|}
\hline \multirow{2}{*}{ Analyte } & \multirow{2}{*}{$\begin{array}{l}\text { Samples } \\
\text { (\% of } 52 \text { ) }\end{array}$} & \multirow{2}{*}{$\begin{array}{l}\text { Stations } \\
(\% \text { of } 14)\end{array}$} & \multirow{2}{*}{ LOD range $(\mu g / g)$} & \multicolumn{4}{|c|}{ Maximum concentration } \\
\hline & & & & $(\mu g / g)$ & Station & Gender & Species \\
\hline Arsenic & 100 & 100 & NA & 0.19 & Willow Beach, AZ (320) & M & Common carp \\
\hline Cadmium & 46 & 79 & $0.024-0.034$ & 0.24 & San Rafael, UT (313) & $\mathrm{M}$ & Common carp \\
\hline Chromium & 81 & 100 & $0.24-0.35$ & 2.38 & Arlington, AZ (325) & $\mathrm{F}$ & Largemouth bass \\
\hline Copper & 100 & 100 & NA & 2.80 & Delta, CO (314) & $\mathrm{F}$ & Brown trout \\
\hline Lead & 2 & 7 & $0.24-0.35$ & 0.29 & Gold Bar Canyon, UT (316) & M & Common carp \\
\hline Mercury & 100 & 100 & NA & 0.37 & San Rafael, UT (313) & $\mathrm{F}$ & Channel catfish \\
\hline Nickel & 6 & 21 & $0.24-0.35$ & 1.73 & Loma, CO (315) & $\mathrm{F}$ & Common carp \\
\hline Selenium & 100 & 100 & NA & 2.95 & Delta, CO (314) & M & Common carp \\
\hline Zinc & 100 & 100 & NA & 99.6 & Arlington, AZ (325) & $\mathrm{F}$ & Common carp \\
\hline
\end{tabular}

emphasizes that multiple life stages need to be examined to correctly assess toxicity and tissue concentration relationships (Jarvinen and Ankley, 1999). Selenium accumulation varies among tissues in fish. Relatively high Se concentrations are found in spleen, liver, kidney, and gonads (Hamilton and others, 2005a). Selenium contamination has also been associated with histopathological effects in the gill, liver, kidney, and ovary of freshwater fish (Sorenson, 1988; Sorenson and others, 1984). Whole-body concentrations of Se should not exceed 4 $\mu \mathrm{g} / \mathrm{g} \mathrm{dw}(1.0 \mu \mathrm{g} / \mathrm{g}$ ww assuming $75 \%$ moisture $)$ to avoid toxicity to the fish and should not exceed $3 \mu \mathrm{g} / \mathrm{g} \mathrm{dw}(0.75 \mu \mathrm{g} / \mathrm{g}$ ww assuming $75 \%$ moisture) to avoid toxicity to piscivorous wildlife (Hamilton, 2004; Lemly, 1996). At least one sample from all CDRB stations exceeded one or both of these thresholds. Selenium continues to represent a risk to aquatic and piscivorous wildlife in the CDRB.

\section{Mercury}

Mercury was detected in all CDRB samples, and the maximum concentration $(0.37 \mu \mathrm{g} / \mathrm{g})$ was measured in female channel catfish from Station 313 (table 10). Concentrations were $>0.1 \mu \mathrm{g} / \mathrm{g}$ in samples from Stations $311,312,313,315$, 316, 317, 321, and 323 (fig. 5). Mean station concentrations were greatest from Stations $313(0.24 \mu \mathrm{g} / \mathrm{g})$ and $311(0.23 \mu \mathrm{g} /$ $\mathrm{g}$ ) in the Upper CDRB (table 11). Predatory fish (bass, channel catfish) accumulate greater $\mathrm{Hg}$ concentrations than bottom feeding fish (carp, sucker; Hinck and others, 2004a, 2004b; Schmitt and others, 1999, 2002, 2004), although carp and bass concentrations were similar at many CDRB stations (fig. 5). Mercury concentrations in predatory fish increase with size (that is, heavier and longer fish have greater concentrations; Brumbaugh and others, 2001); therefore, $\mathrm{Hg}$ concentrations of $\mathrm{Hg}$ adjusted for weight and length were examined. Relating concentrations of $\mathrm{Hg}$ in composite samples to individual length and weight measurements is difficult although overall trends or patterns can be identified. The length- or weightadjusted $\mathrm{Hg}$ concentrations ( $\mathrm{HgL}$ and $\mathrm{HgW}$, respectively) were greater (some $>0.4 \mu \mathrm{g} / \mathrm{g}$ ) than the unadjusted concentrations (none $>0.5 \mu \mathrm{g} / \mathrm{g}$ ). The greatest $\mathrm{HgL}$ and $\mathrm{HgW}$ concentrations were measured in channel catfish from Stations 312, 313, and 316 and white sucker from Station 311 (fig. 5). The current study design (that is, measuring concentrations in composite samples) cannot definitively account for the contribution of size to concentrations of $\mathrm{Hg}$.

Concentrations of $\mathrm{Hg}$ in carp, bass, and channel catfish differed significantly among CDRB stations (table 12). Concentrations of unadjusted $\mathrm{Hg}$ in carp were significantly greater from Stations 312, 313, and 316 in the Upper CDRB and Station 323 in the Middle GR than from most other stations. Significantly greater concentrations of $\mathrm{Hg}$ were measured in bass from Station 311 (all smallmouth bass) than those from other stations (all largemouth bass; table 12). Similar to carp, concentrations of $\mathrm{Hg}$ were significantly greater in channel catfish from Stations 312 and 313 on the Green River than from other sites (table 12). The relative rankings of the stations for $\mathrm{Hg}, \mathrm{HgL}$, and $\mathrm{HgW}$ were similar for carp, bass, and channel catfish (table 12). Most relative differences remained after adjusting for fish size, which suggests that spatial differences were not entirely artifacts of fish size.

Mercury concentrations in CDRB fish were similar to those from other CDRB studies. The maximum historical NCBP concentrations were $0.23 \mu \mathrm{g} / \mathrm{g}$ in carp, $0.41 \mu \mathrm{g} / \mathrm{g}$ in bass, and $0.2 \mu \mathrm{g} / \mathrm{g}$ in channel catfish from 1971 to 1986 (Schmitt and others, 1999), which were greater than most 
Table 11. Unweighted geometric mean, minimum (Min), and maximum (Max) concentrations ( $\mu \mathrm{g} / \mathrm{g}$, wet-weight) of elemental contaminants in fish collected in the Colorado River Basin in 2003. Censored values were replaced by one-half the value for the LOD for the computation of station means, but only if at least one value exceeded the LOD. The maximum geometric station mean is shown in bold for each contaminant. Stations are listed upstream to downstream.

\begin{tabular}{|c|c|c|c|c|c|c|c|c|c|c|}
\hline \multirow{2}{*}{ Sub-basin, station } & & \multicolumn{9}{|c|}{ Element } \\
\hline & & As & Cd & $\mathrm{Cr}$ & Cu & $\mathrm{Hg}$ & $\mathrm{Ni}$ & $\mathbf{P b}$ & Se & $\mathrm{Zn}$ \\
\hline \multicolumn{11}{|l|}{ Upper Colorado River Basin } \\
\hline Lay, CO (311) & Mean & 0.06 & 0.03 & 0.50 & 0.59 & 0.23 & $<0.34$ & $<0.34$ & 0.88 & 14.0 \\
\hline \multirow[t]{2}{*}{$n=4$} & Min & 0.05 & $<0.03$ & 0.37 & 0.40 & 0.18 & $<0.31$ & $<0.31$ & 0.81 & 12.8 \\
\hline & $\operatorname{Max}$ & 0.07 & 0.05 & 0.85 & 0.85 & 0.27 & $<0.34$ & $<0.34$ & 1.03 & 16.3 \\
\hline Ouray NWR, UT (312) & Mean & 0.07 & 0.05 & 0.50 & 0.66 & 0.18 & $<0.30$ & $<0.30$ & 1.18 & 39.1 \\
\hline \multirow[t]{2}{*}{$n=4$} & Min & 0.06 & 0.03 & 0.39 & 0.47 & 0.14 & $<0.24$ & $<0.24$ & 0.95 & 17.6 \\
\hline & $\operatorname{Max}$ & 0.09 & 0.10 & 0.62 & 0.82 & 0.21 & $<0.30$ & $<0.30$ & 1.48 & 93.8 \\
\hline San Rafael, UT (313) & Mean & 0.05 & 0.05 & 0.27 & 0.62 & 0.24 & $<0.29$ & $<0.29$ & 1.17 & 40.8 \\
\hline \multirow[t]{2}{*}{$n=4$} & Min & 0.02 & $<0.03$ & $<0.24$ & 0.41 & 0.16 & $<0.24$ & $<0.24$ & 0.80 & 18.6 \\
\hline & $\operatorname{Max}$ & 0.13 & 0.24 & 0.73 & 0.95 & 0.37 & $<0.29$ & $<0.29$ & 1.75 & 89.3 \\
\hline Delta, CO (314) & Mean & 0.05 & 0.02 & 0.23 & 1.58 & 0.07 & $<0.33$ & $<0.33$ & 2.28 & 53.4 \\
\hline \multirow[t]{2}{*}{$n=4$} & Min & 0.04 & $<0.03$ & $<0.29$ & 1.05 & 0.05 & $<0.28$ & $<0.28$ & 1.63 & 34.3 \\
\hline & $\operatorname{Max}$ & 0.10 & 0.04 & 0.43 & 2.80 & 0.09 & $<0.33$ & $<0.33$ & 2.95 & 95.1 \\
\hline Loma, CO (315) & Mean & 0.05 & 0.03 & 0.39 & 0.68 & 0.08 & 0.27 & $<0.34$ & 2.08 & 31.6 \\
\hline \multirow[t]{2}{*}{$n=4$} & Min & 0.03 & $<0.03$ & 0.31 & 0.34 & 0.06 & $<0.27$ & $<0.27$ & 1.97 & 13.5 \\
\hline & $\operatorname{Max}$ & 0.08 & 0.09 & 0.56 & 1.20 & 0.10 & 1.73 & $<0.34$ & 2.25 & 81.9 \\
\hline Gold Bar Canyon, UT (316) & Mean & 0.02 & 0.04 & 0.47 & 0.64 & 0.16 & $<0.29$ & 0.15 & 1.43 & 39.8 \\
\hline \multirow[t]{2}{*}{$n=4$} & Min & 0.02 & $<0.02$ & 0.31 & 0.36 & 0.13 & $<0.24$ & $<0.24$ & 0.93 & 19.9 \\
\hline & $\operatorname{Max}$ & 0.03 & 0.21 & 0.86 & 0.91 & 0.18 & $<0.29$ & 0.29 & 2.03 & 88.3 \\
\hline Hogback Diversion, NM (317) & Mean & 0.03 & 0.03 & 0.32 & 0.73 & 0.11 & $<0.31$ & $<0.31$ & 0.88 & 38.2 \\
\hline \multirow[t]{2}{*}{$n=4$} & Min & 0.03 & $<0.03$ & $<0.31$ & 0.46 & 0.10 & $<0.29$ & $<0.29$ & 0.51 & 17.7 \\
\hline & $\operatorname{Max}$ & 0.04 & 0.09 & 0.34 & 1.16 & 0.12 & $<0.31$ & $<0.31$ & 1.72 & 82.5 \\
\hline \multicolumn{11}{|l|}{ Lower Colorado River Basin } \\
\hline South Cove, AZ (319) & Mean & 0.14 & 0.08 & 0.28 & 1.23 & 0.04 & $<0.30$ & $<0.30$ & 2.13 & 73.5 \\
\hline \multirow[t]{2}{*}{$n=2$} & Min & 0.11 & 0.06 & $<0.30$ & 1.09 & 0.04 & $<0.30$ & $<0.30$ & 2.08 & 72.4 \\
\hline & $\operatorname{Max}$ & 0.17 & 0.12 & 0.54 & 1.39 & 0.04 & $<0.30$ & $<0.30$ & 2.19 & 75.4 \\
\hline Willow Beach, AZ (320) & Mean & 0.17 & 0.04 & 0.48 & 1.21 & 0.02 & $<0.31$ & $<0.31$ & 1.63 & 76.1 \\
\hline \multirow[t]{2}{*}{$n=2$} & Min & 0.15 & 0.04 & 0.40 & 1.20 & 0.02 & $<0.31$ & $<0.31$ & 1.56 & 64.6 \\
\hline & Max & 0.19 & 0.05 & 0.58 & 1.23 & 0.02 & $<0.31$ & $<0.31$ & 1.70 & 89.0 \\
\hline Needles, CA (321) & Mean & 0.08 & 0.01 & 0.30 & 0.85 & 0.05 & 0.27 & $<0.34$ & 2.19 & 35.4 \\
\hline \multirow[t]{2}{*}{$n=4$} & Min & 0.05 & $<0.03$ & $<0.34$ & 0.52 & 0.03 & $<0.26$ & $<0.24$ & 1.79 & 15.9 \\
\hline & $\operatorname{Max}$ & 0.13 & $<0.03$ & 0.68 & 1.12 & 0.12 & 1.53 & $<0.34$ & 2.62 & 89.4 \\
\hline Imperial Dam, AZ (322) & Mean & 0.10 & 0.02 & 0.29 & 0.58 & 0.02 & $<0.35$ & $<0.35$ & 2.57 & 31.8 \\
\hline \multirow[t]{2}{*}{$n=4$} & Min & 0.05 & $<0.03$ & $<0.34$ & 0.34 & 0.01 & $<0.29$ & $<0.29$ & 2.34 & 15.6 \\
\hline & $\operatorname{Max}$ & 0.14 & 0.04 & 0.72 & 0.92 & 0.04 & $<0.35$ & $<0.35$ & 2.72 & 64.7 \\
\hline
\end{tabular}


Table 11. Unweighted geometric mean, minimum (Min), and maximum (Max) concentrations ( $\mu \mathrm{g} / \mathrm{g}$, wet-weight) of elemental contaminants in fish collected in the Colorado River Basin in 2003. Censored values were replaced by one-half the value for the LOD for the computation of station means, but only if at least one value exceeded the LOD. The maximum geometric station mean is shown in bold for each contaminant. Stations are listed upstream to downstream.-Continued

\begin{tabular}{|c|c|c|c|c|c|c|c|c|c|c|}
\hline \multirow{2}{*}{ Sub-basin, station } & & \multicolumn{9}{|c|}{ Element } \\
\hline & & As & Cd & $\mathrm{Cr}$ & $\mathrm{Cu}$ & $\mathrm{Hg}$ & $\mathrm{Ni}$ & $\mathbf{P b}$ & $\mathrm{Se}$ & $\mathrm{Zn}$ \\
\hline Hayden, AZ (323) & Mean & 0.12 & 0.03 & 0.47 & 1.11 & 0.12 & 0.22 & $<0.28$ & 0.63 & 33.6 \\
\hline \multirow[t]{2}{*}{$n=4$} & Min & 0.08 & $<0.03$ & 0.33 & 0.89 & 0.09 & $<0.26$ & $<0.26$ & 0.52 & 15.5 \\
\hline & $\operatorname{Max}$ & 0.16 & 0.11 & 0.87 & 1.27 & 0.16 & 0.87 & $<0.28$ & 0.80 & 73.3 \\
\hline Phoenix, AZ (324) & Mean & 0.03 & 0.02 & 0.42 & 0.64 & 0.04 & $<0.33$ & $<0.33$ & 1.03 & 42.1 \\
\hline \multirow[t]{2}{*}{$n=4$} & Min & 0.01 & $<0.03$ & 0.36 & 0.43 & 0.04 & $<0.30$ & $<0.30$ & 0.57 & 24.1 \\
\hline & $\operatorname{Max}$ & 0.08 & $<0.03$ & 0.46 & 0.90 & 0.05 & $<0.33$ & $<0.33$ & 1.73 & 75.2 \\
\hline Arlington, AZ (325 & Mean & 0.06 & 0.01 & 0.58 & 0.61 & 0.04 & $<0.29$ & $<0.29$ & 1.86 & 32.1 \\
\hline \multirow[t]{2}{*}{$n=4$} & Min & 0.03 & $<0.03$ & 0.32 & 0.38 & 0.02 & $<0.28$ & $<0.28$ & 1.42 & 13.2 \\
\hline & $\operatorname{Max}$ & 0.08 & $<0.03$ & 2.38 & 0.88 & 0.06 & $<0.29$ & $<0.29$ & 2.69 & 99.6 \\
\hline
\end{tabular}

concentrations in 2003 samples from Stations 312, 319, 320, 321, 322, and 323. Concentrations in carp from Stations 321 and 322 were similar to those reported by Radtke and others (1988), and $\mathrm{Hg}$ concentrations were $<\mathrm{LOD}(0.05 \mu \mathrm{g} / \mathrm{g})$ in whole-body carp near Station 321 and upstream Station 322. Mercury concentrations in carp and white sucker from Station 312 were $0.01-0.22 \mu \mathrm{g} / \mathrm{g}$ and $0.01-0.02 \mu \mathrm{g} / \mathrm{g}$, respectively, in 1991-1993 (Rowland and others, 2002).

Multiple USFWS studies have documented Hg concentrations in fish from the GRB. In 1994 and 1995, concentrations of $\mathrm{Hg}$ were measured in whole-body carp (0.04-0.41 $\mu \mathrm{g} / \mathrm{g})$, largemouth bass $(0.07-0.09 \mu \mathrm{g} / \mathrm{g})$, and channel catfish $(0.03-0.11 \mu \mathrm{g} / \mathrm{g})$ from the GRB near Stations 324 and 325 (King and others, 1997). Concentrations were low in channel catfish $(0.02 \mu \mathrm{g} / \mathrm{g})$ from the Lower GRB and Yuma Valley (Baker and others, 1992). Mercury concentrations in fish from Imperial, Cibola, and Havasu NWRs $(<0.08 \mu \mathrm{g} / \mathrm{g})$ did not represent a threat to piscivorous wildlife in 1988-1989 (Andrews and others, 1997; King and others, 1993), and concentrations in fish from the Middle GR near Station $323(<0.01-0.08 \mu \mathrm{g} / \mathrm{g})$ were below protective criteria for wildlife (Andrews and King, 1997).

Concentrations of $\mathrm{Hg}$ in carp, bass, and channel catfish were measured in previous LRMN studies. In carp, concentrations were 0.04-0.34 $\mu \mathrm{g} / \mathrm{g}$ in the MRB (Schmitt and others, 2002), 0.03-0.20 $\mu \mathrm{g} / \mathrm{g}$ in the RGB (Schmitt and others, 2004 ), and $<0.05-0.20 \mu \mathrm{g} / \mathrm{g}$ in the CRB (Hinck and others, 2004a). Concentrations in bass were $0.05-0.45 \mu \mathrm{g} / \mathrm{g}$ in the MRB (Schmitt and others, 2002), 0.07-0.45 $\mu \mathrm{g} / \mathrm{g}$ in the RGB (Schmitt and others, 2004), and 0.06-0.31 $\mu \mathrm{g} / \mathrm{g}$ in the CRB (Hinck and others, 2004a). Mercury concentrations in channel catfish ranged from 0.05 to $0.09 \mu \mathrm{g} / \mathrm{g}$ in the RGB (Schmitt and others, 2004). Overall, $\mathrm{Hg}$ concentrations in CDRB fish were less than those measured in previous LRMN studies (table 13).
Fish populations are at greatest risk from $\mathrm{Hg}$ during embryonic and larval stages partially due to maternal transfer (Wiener and Spry, 1996). Behavioral effects in laboratory studies have been documented in fish containing whole-body concentrations of 0.7-5.4 $\mu \mathrm{g} / \mathrm{g}$ (Kania and O'Hara, 1974; Wiener and Spry, 1996). Permanent impairment of grayling (Thymallus thymallus) fry feeding efficiency and competitive ability occurred at $\mathrm{Hg}$ concentrations of $0.27 \mu \mathrm{g} / \mathrm{g}$ (Fjeld and others, 1998). Dietary Hg exposure increased mortality $(0.20-0.47 \mu \mathrm{g} / \mathrm{g})$ and altered sex ratios $(0.44-1.1 \mu \mathrm{g} / \mathrm{g})$ of adult mummichog (Fundulus heteroclitus) and reduced fertilization success (0.01-0.63 $\mu \mathrm{g} / \mathrm{g}$ ) of eggs (Matta and others, 2001). Jarvinen and Ankley (1999) reviewed various laboratory studies evaluating the effects of $\mathrm{Hg}$ on reproduction in freshwater fish. Included were studies that found reduced reproduction at whole-body concentrations of $4.47 \mu \mathrm{g} / \mathrm{g}$ in fathead minnows (Snarski and Olson, 1982) and $9.4 \mu \mathrm{g} / \mathrm{g}$ in second-generation brook trout (Salvelinus fontinalis) (McKim and others, 1976). In fathead minnows, dietary $\mathrm{Hg}$ concentrations of $0.87 \mu \mathrm{g} / \mathrm{g}$ $\mathrm{dw}(0.22 \mu \mathrm{g} / \mathrm{g}$ ww assuming $75 \%$ moisture $)$ increased wholebody concentrations over 10-fold, suppressed hormone levels, and inhibited gonadal development in females (Drevnick and Sandheinrich, 2003). Whole-body concentrations associated with behavioral and reproductive effects were approximately $5 \mu \mathrm{g} / \mathrm{g}$ for brook trout and $10 \mu \mathrm{g} / \mathrm{g}$ for rainbow trout (Wiener and Spry, 1996; Wiener and others, 2002). However, caution should be used with these thresholds because many factors can contribute uncertainty to these critical tissue concentration estimates (Wiener and others, 2002).

Dietary concentrations of $\mathrm{Hg}$ in wildlife as low as 0.3 $\mu \mathrm{g} / \mathrm{g}$ have been associated with reproductive impairment in common loons (Gavia immer; Barr, 1986), and reproduction in mallards (Anas platyrhynchos) was affected at concentrations as low as $0.1 \mu \mathrm{g} / \mathrm{g}$ (Heinz, 1979). Dietary concentrations of $0.25-1.0 \mu \mathrm{g} / \mathrm{g}$ may also be toxic to piscivorous mammals 


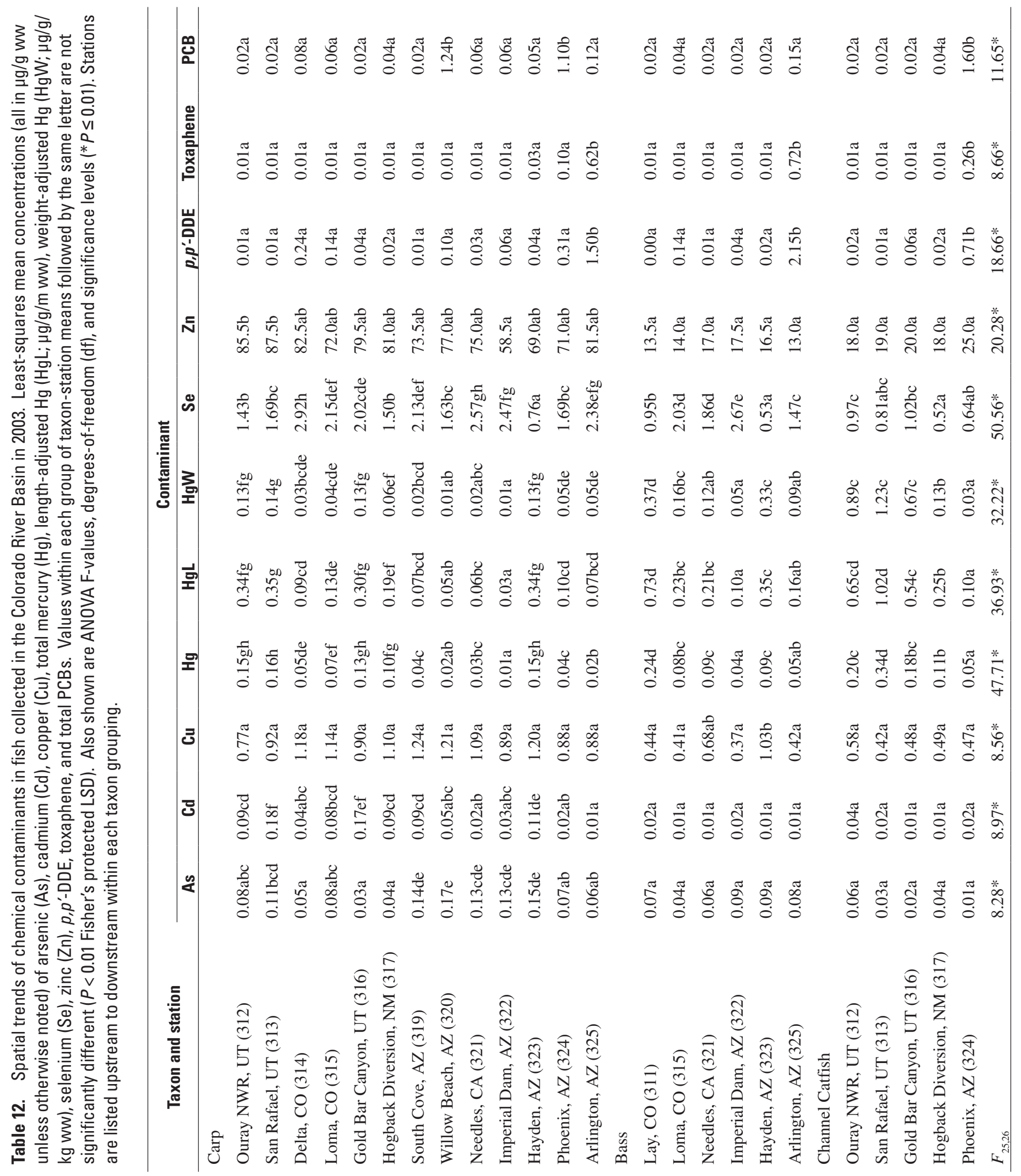




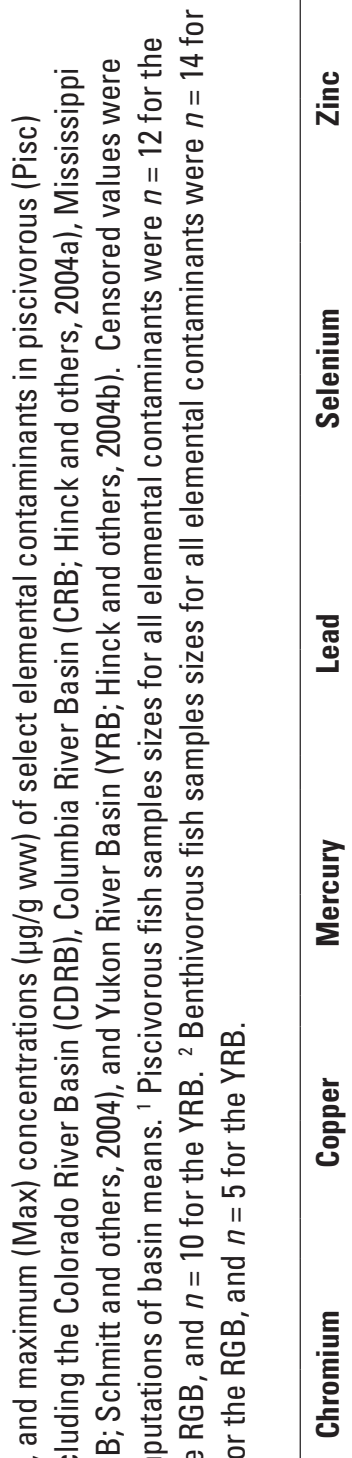

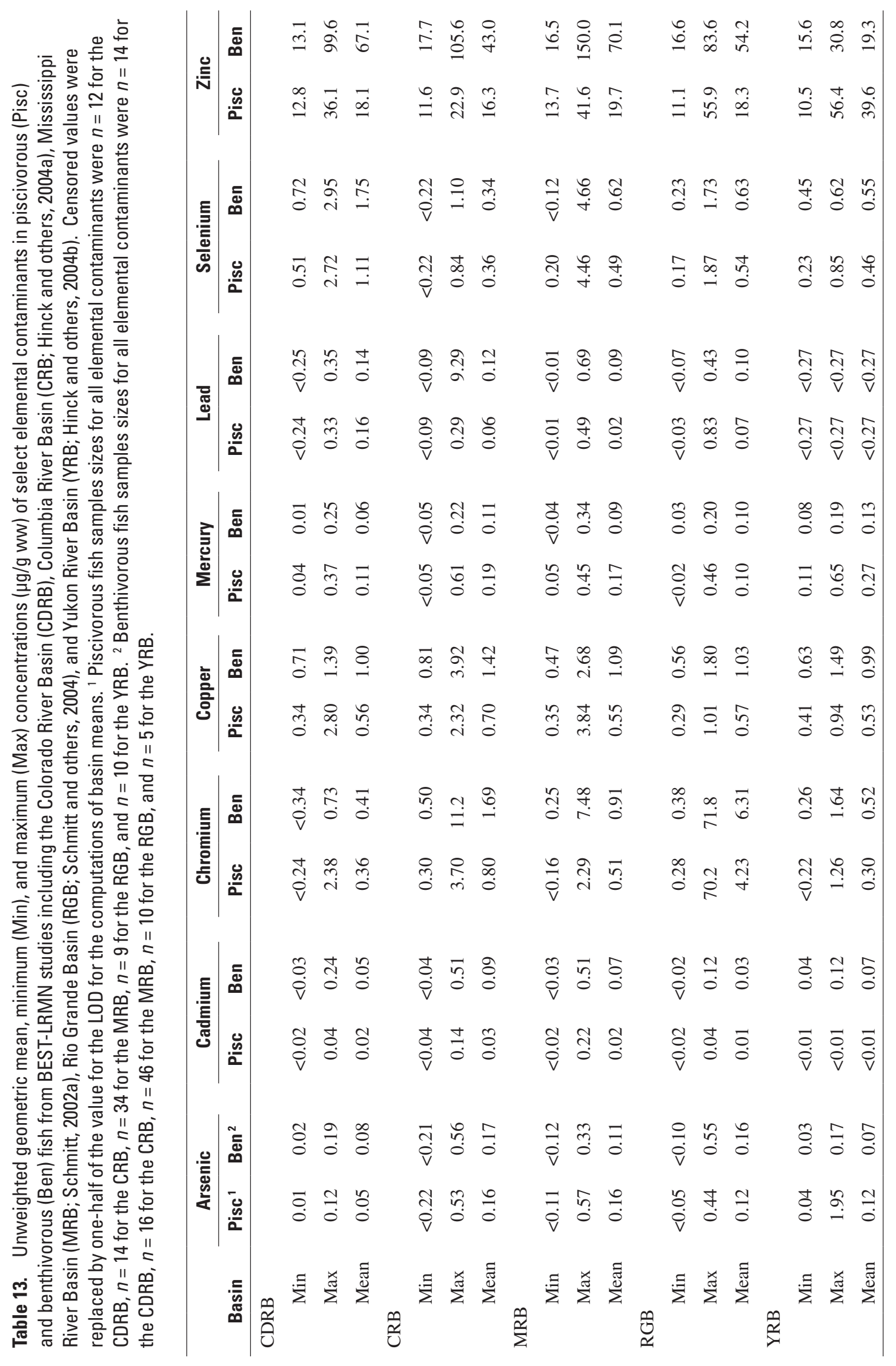




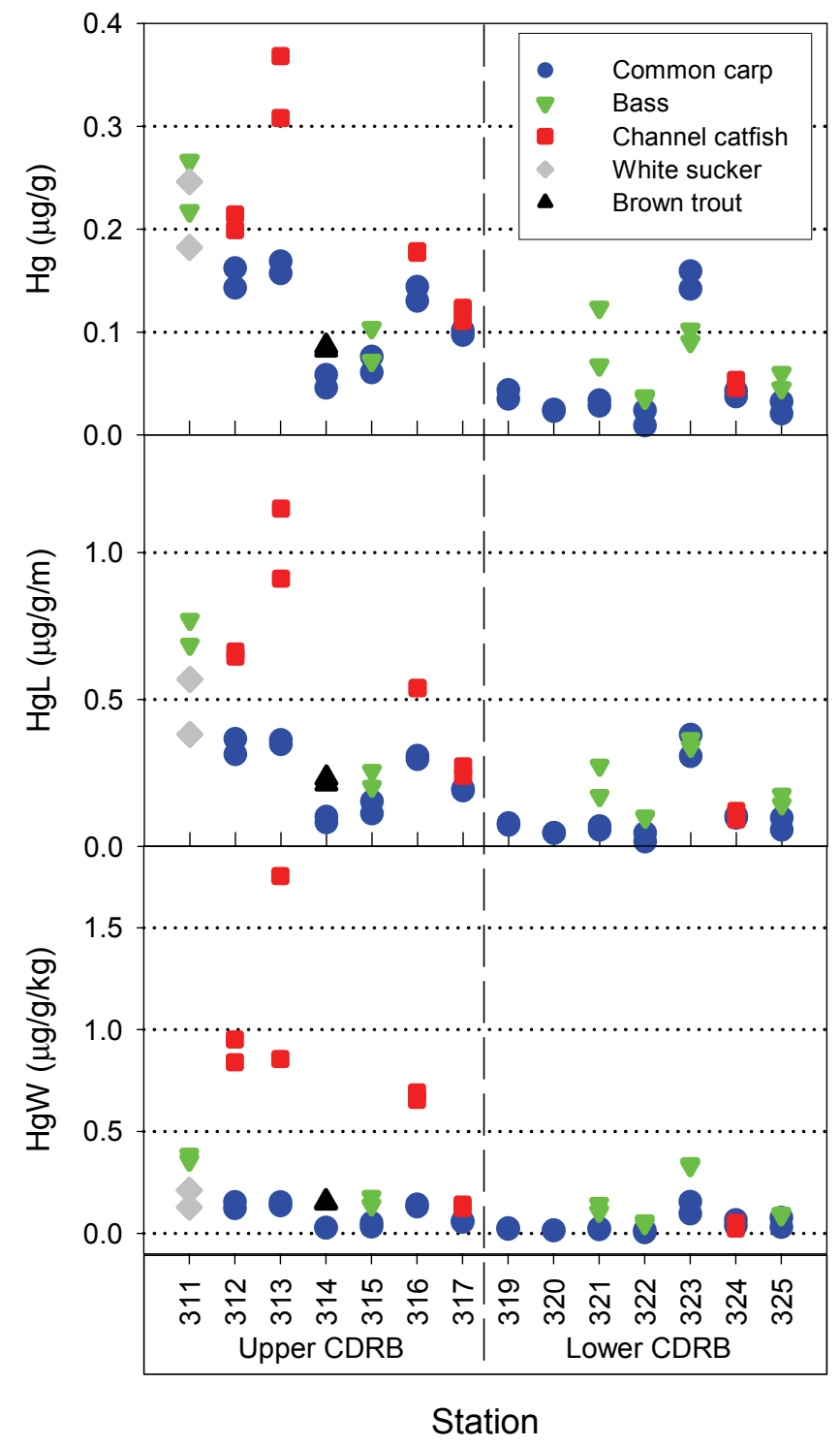

Figure 5. Concentrations ( $\mu \mathrm{g} / \mathrm{g} \mathrm{ww})$ of total mercury $(\mathrm{Hg})$ by station and taxon in whole-body fish composite samples from the Colorado River Basin in 2003. Unadjusted $(\mathrm{Hg})$, length-adjusted $(\mathrm{HgL})$, and weight-adjusted $(\mathrm{HgW})$ concentrations are shown. Censored values are plotted as one half the LOD. Stations are ordered from upstream to downstream and are grouped by sub-basin. See text for computations and Table 2 for station descriptions

(studies reviewed by Wolfe and others, 1998). Neurotoxicity and mortality occurred in adult minks (Mustela vison) after chronic exposure to dietary $\mathrm{Hg}$ concentrations $>1 \mu \mathrm{g} / \mathrm{g}$ (Dansereau and others, 1999; Wobeser and others, 1976; Wren and others, 1987). Consequently, guidelines for the protection of piscivorous wildlife range from 0.5 to $1.0 \mu \mathrm{g} / \mathrm{g}$ (Eisler, 1987; Thompson, 1996), and values as low as $0.1 \mu \mathrm{g} / \mathrm{g}$ for mammals and $0.02 \mu \mathrm{g} / \mathrm{g}$ for birds have been derived from water quality criteria and bioaccumulation factors (Yeardley and others, 1998). Selenium affords a degree of protection against $\mathrm{Hg}$ toxicity in wildlife by demethylation to inorganic mercury when $\mathrm{Se}$ and $\mathrm{Hg}$ are in molar ratio of 1:1 (Dietz and others, 1990; Heinz and Hoffman, 1998; Scheuhammer and others, 1998; Wiener and others, 2002). However, studies have shown Se-enhanced $\mathrm{Hg}$ embryo toxicity in birds (Heinz and Hoffman, 1998). Thus, although the significant amounts of Se may protect adult birds from the toxic effects of $\mathrm{Hg}$, reproductive effects may be exacerbated. Mercury concentrations in channel catfish from Station 313 exceeded $0.3 \mu \mathrm{g} / \mathrm{g}$, and at least one sample from Stations 311, 312, 313, 315, 316, 317, 321, and 323 exceeded $0.1 \mu \mathrm{g} / \mathrm{g}$ (fig. 5). Therefore, CDRB wildlife may be at risk from exposure to $\mathrm{Hg}$.

\section{Cadmium}

Concentrations of Cd were >LOD (0.024-0.034 $\mu \mathrm{g} / \mathrm{g})$ in 24 samples (46\%) from 11 stations (table 10). Concentrations were $>0.2 \mu \mathrm{g} / \mathrm{g}$ in two carp samples only (fig. 6), and the maximum concentration $(0.24 \mu \mathrm{g} / \mathrm{g})$ was measured in male carp from Station 313. The greatest station mean $(0.08$ $\mu \mathrm{g} / \mathrm{g}$ ) was at Station 319 (table 11). Cadmium concentrations were greater in carp compared to other species, and concentrations were greater in carp than predator species collected concomitantly in previous LRMN studies (Hinck and others, 2004a; Schmitt and others, 2002, 2004). Concentrations of Cd differed significantly among stations in carp but not in bass or channel catfish (table 12). Concentrations were significantly greater in carp from Stations 313 and 316 than at all others except Station 323 (table 12; fig. 6).

Cadmium concentrations in 2003 samples were low as reported by previous CDRB investigations (Andrews and King, 1997; Baker and others, 1992; Butler and others, 1996; King and others, 1997; Rowland and others, 2002; Stephens and others, 1988). Historical NCBP concentrations of Cd were generally low in carp $(\leq 0.18 \mu \mathrm{g} / \mathrm{g})$, bass $(\leq 0.05 \mu \mathrm{g} / \mathrm{g})$, and channel catfish $(\leq 0.12 \mu \mathrm{g} / \mathrm{g})$ from 1971 to 1986 , but relatively high concentrations $(>0.15 \mu \mathrm{g} / \mathrm{g})$ were measured in carp near Stations 312, 319, and 320 (Schmitt and others, 1999). In previous LRMN studies, Cd concentrations in carp were $<0.02-0.51 \mu \mathrm{g} / \mathrm{g}$ in the MRB (Schmitt and others, 2002), $<0.02-0.12 \mu \mathrm{g} / \mathrm{g}$ in the RGB (Schmitt and others, 2004), and $<0.04-0.51 \mu \mathrm{g} / \mathrm{g}$ in the CRB (Hinck and others, 2004a). In bass, concentrations were $<0.02-0.22 \mu \mathrm{g} / \mathrm{g}$ in the MRB (Schmitt and others, 2002) and <LOD $(0.02 \mu \mathrm{g} / \mathrm{g})$ in the RGB and CRB (Hinck and others, 2004a; Schmitt and others, 2004). Concentrations in channel catfish were $<$ LOD $(\sim 0.03 \mu \mathrm{g} / \mathrm{g})$ in the RGB (Schmitt and others, 2004). Cadmium concentrations in CDRB fish were similar to those measured in previous LRMN studies (table 13).

Birds and mammals are comparatively resistant to $\mathrm{Cd}$. Dietary toxicity thresholds were $>100 \mu \mathrm{g} / \mathrm{g}$ in the studies reviewed by Eisler (1985). Eisler (1985) suggested that a Cd concentration of $2 \mu \mathrm{g} / \mathrm{g}$ in fish is evidence of contamination, that $5 \mu \mathrm{g} / \mathrm{g}$ is potentially life-threatening to the fish, and that $13-15 \mu \mathrm{g} / \mathrm{g}$ is a threat to higher trophic levels. A review by Jarvinen and Ankley (1999) included several laboratory stud- 


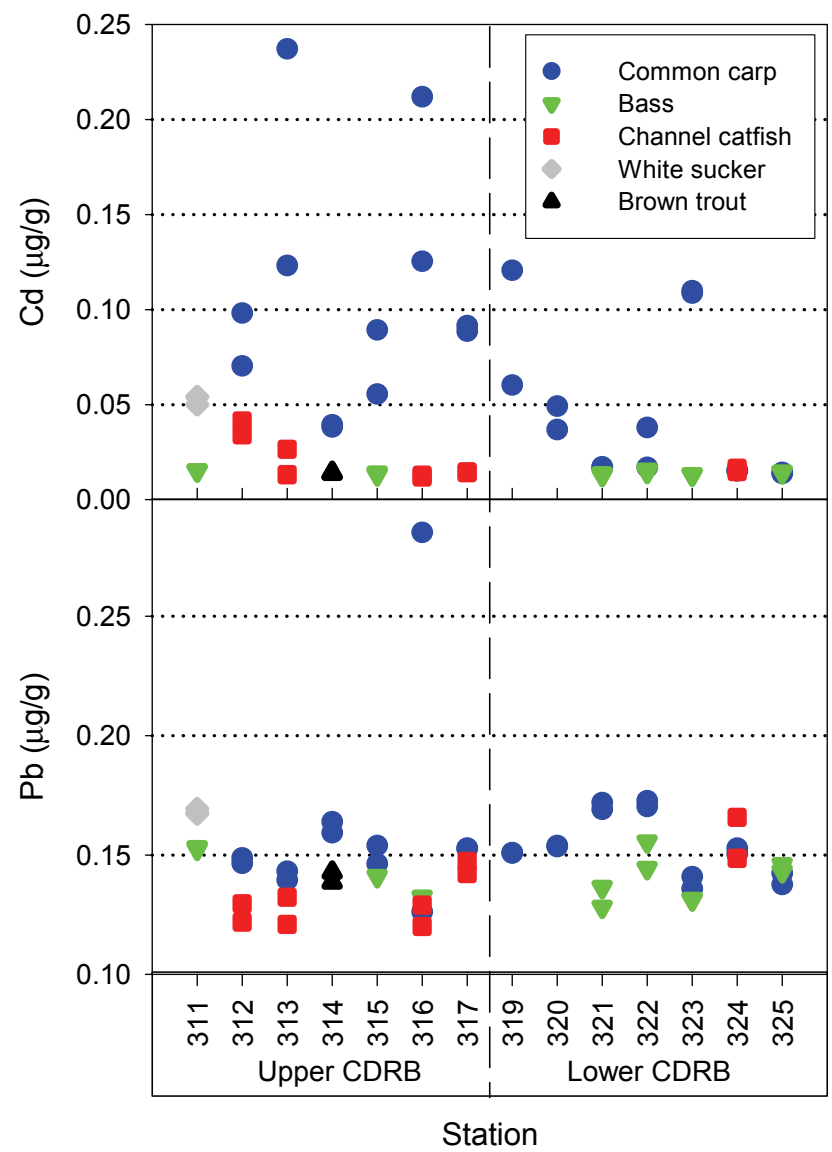

Figure 6. Concentrations ( $\mu \mathrm{g} / \mathrm{g}$ ww) of cadmium ( $\mathrm{Cd}$ ) and lead $(\mathrm{Pb})$ by station and taxon in whole-body fish composite samples from the Colorado River Basin in 2003. Censored values are plotted as one half the LOD. Stations are ordered from upstream to downstream and are grouped by sub-basin. See Table 2 for station descriptions.

ies in which whole-body concentrations of $\mathrm{Cd}$ in freshwater fish of $0.12-15.6 \mu \mathrm{g} / \mathrm{g}$ resulted in reduced survival, growth, or both, and concentrations of 2-8 $\mu \mathrm{g} / \mathrm{g}$ caused decreased spawning and embryo production. Concentrations of $\mathrm{Cd}$ in $\mathrm{CDRB}$ fish were below these benchmarks.

\section{Lead}

Concentrations of $\mathrm{Pb}$ were $<\mathrm{LOD}$ in all samples except male carp $(0.29 \mu \mathrm{g} / \mathrm{g})$ from Station 316 (fig. 6; table 10). These low concentrations of $\mathrm{Pb}$ are similar to those reported by previous CDRB studies (Andrews and others, 1997; Baker and others, 1992; Radtke and others, 1988; Roland and others, 2002; Schmitt and others, 1999; Stephens and others, 1988). Andrews and King (1997) reported that Pb concentrations $(0.54-2.34 \mu \mathrm{g} / \mathrm{g})$ in fish from the Middle GR, an area with mine drainage, may threaten fish survival and reproduction; however, concentrations of most samples from the study were $<\mathrm{LOD}$. Concentrations of $\mathrm{Pb}$ in carp, bass, and channel catfish from previous LRMN studies were generally less than those measured in the CDRB (table 13; Hinck and others, 2004a; Schmitt and others, 2002, 2004).

The effects threshold of $\mathrm{Pb}$ in fish is $\geq 0.4 \mu \mathrm{g} / \mathrm{g}$ based on whole-body concentrations [(Holcombe and others, 1976) as reviewed in Jarvinen and Ankley (1999)]. Whole-body Pb concentrations of $0.4 \mu \mathrm{g} / \mathrm{g}$ reduced hatchability and 4.0-8.8 $\mu \mathrm{g} / \mathrm{g}$ reduced growth in third generation brook trout at various life stages (Holcombe and others, 1976). Concentrations in CDRB fish did not approach these values. CDRB wildlife are not at risk from $\mathrm{Pb}$.

Zinc

Zinc was detected in all samples (12.8-99.6 $\mu \mathrm{g} / \mathrm{g})$, and the maximum concentration was measured in female carp from Station 325 (fig. 7; table 10). Concentrations were $>52$ $\mu \mathrm{g} / \mathrm{g}$ in carp samples while all other samples were $<36 \mu \mathrm{g} / \mathrm{g}$. Station means were $>70 \mu \mathrm{g} / \mathrm{g}$ at Stations 319 and 320, but carp was the only species from these sites (table 11). Carp were not collected from Station 311, the station with the lowest geometric station mean $(14.0 \mu \mathrm{g} / \mathrm{g})$. Concentrations of $\mathrm{Zn}$ differed significantly among stations in carp but not in bass or channel catfish (table 12). Concentrations were significantly greater in carp from Stations 312 and 313 on the Green River than from Station 322 in the Lower CDRB.

Zinc concentrations were similar to historical NCBP concentrations in carp (42-110 $\mu \mathrm{g} / \mathrm{g})$, bass $(11-27 \mu \mathrm{g} / \mathrm{g})$, and channel catfish (17-23 $\mu \mathrm{g} / \mathrm{g}$; Schmitt and others, 1999). Some of the greatest historical $\mathrm{Zn}$ concentrations were in carp from the Green River (near Station 312) and the CDR at Lake Mead (near Stations 319 and 320), Lake Martinez (near Station 322), and Lake Havasu (near Station 321). Historical concentrations in carp, bass, and channel catfish in the Lower CDR (Andrews and others, 1997; King and others, 1993; Radtke and others, 1988) and the GRB (Baker and others, 1992; King and others, 1997) were similar to 2003 concentrations. However, Zn concentrations in carp from Station $312(>75 \mu \mathrm{g} / \mathrm{g})$ were greater than those from a previous study (27-54 $\mu \mathrm{g} / \mathrm{g}$; Rowland and others, 2002). Sun and Jeng (1998) reported that concentrations of $\mathrm{Zn}$ in carp commonly exceed $100 \mu \mathrm{g} / \mathrm{g}$ and determined that carp partition $\mathrm{Zn}$ in their digestive tissue and generally had greater concentrations than other species. Zinc concentrations in CDRB fish were similar to those reported in the MRB (Schmitt and others, 2002), RGB (Schmitt and others, 2004), and CRB (Hinck and others, 2004a; table 13). Because $\mathrm{Zn}$ is an essential nutrient, it is unlikely to be potentially harmful to CDRB fish or piscivorous wildlife (Eisler, 1993).

\section{Copper}

Copper was detected in all samples, and the maximum concentrations $(1.61-2.80 \mu \mathrm{g} / \mathrm{g})$ were in brown trout from Station 314 (fig. 7; table 10). All other concentrations were $<1.39$ $\mu \mathrm{g} / \mathrm{g}$. Stations means were $>1.0 \mu \mathrm{g} / \mathrm{g}$ at Stations 314, 319, 320 , and 323 (table 11). Concentrations of $\mathrm{Cu}$ differed significantly among CDRB stations in bass but not in carp or channel catfish (table 12). Concentrations of $\mathrm{Cu}$ were significantly 


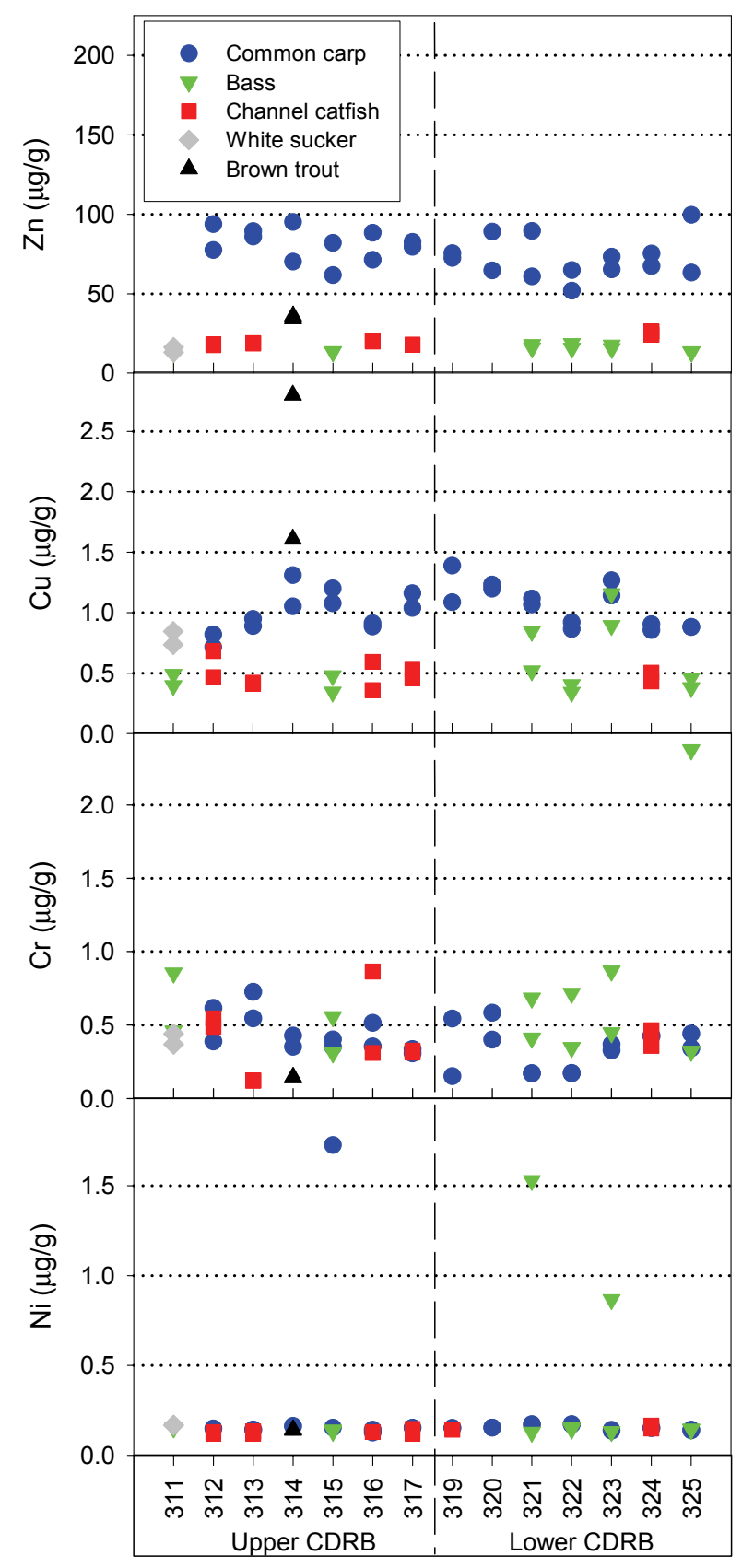

Station

Figure 7. Concentrations ( $\mu \mathrm{g} / \mathrm{g} \mathrm{ww}$ ) of zinc (Zn), copper (Cu), chromium (Cr), and nickel (Ni) by station and taxon in whole-body fish composite samples from the Colorado River Basin in 2003. Censored values are plotted as one half the LOD. Stations are ordered from upstream to downstream and are grouped by subbasin. See Table 2 for station descriptions.

greater in bass from Station 323 than all other sites except Station 321 (table 12). Station 323 is located near $\mathrm{Cu}$ mining operations in the GRB.

In general, $\mathrm{Cu}$ concentrations in $\mathrm{CDRB}$ fish were similar to those from the NCBP (Schmitt and others, 1999) and previous LRMN investigations (table 13; Hinck and others, 2004a;
Schmitt and others, 2002, 2004). Copper was identified as a contaminant of concern in the GRB where sources include mining operations and urban runoff (Andrews and King, 1997; Baker and others, 1992; King and others, 1997) and in several NWRs in the Lower CDR (Andrews and others, 1997; King and others, 1993).

The ecological relevance of $\mathrm{Cu}$ in $\mathrm{CDRB}$ fish is unknown, and tissue-based criteria for $\mathrm{Cu}$ are not available for the protection of avian and mammalian wildlife (Eisler, 1997). Cyprinids appear to be less sensitive to $\mathrm{Cu}$ toxicity than salmonids although high concentrations can cause more severe gill damage and epithelial swelling in carp (De Boeck and others, 2004). Chronic $\mathrm{Cu}$ exposure has been associated with physiological effects including changes in oxygen consumption, ionic regulation, and cell types as well as endocrine disrupting effects such as adrenergic response and cortisol release (Handy, 2003). Copper accumulates in the kidney during chronic exposure, and fish exposed to dietary $\mathrm{Cu}$ may also have increased MA activity in the kidney (Handy, 2003).

\section{Chromium}

Concentrations of $\mathrm{Cr}$ were $>\operatorname{LOD}(0.24-0.35 \mu \mathrm{g} / \mathrm{g})$ in 42 of 52 samples $(81 \%)$ representing all sites (table 10). The maximum concentration was measured in female bass $(2.38$ $\mu \mathrm{g} / \mathrm{g}$ ) from Station 325, and all other concentrations were $<0.87 \mu \mathrm{g} / \mathrm{g}$ (fig. 7; table 10). The greatest mean concentration $(0.58 \mu \mathrm{g} / \mathrm{g})$ was from Station 325 on the GR (table 11$)$.

Previous studies have measured $\mathrm{Cr}$ in fish from the CDRB. Chromium concentrations were $0.22-0.75 \mu \mathrm{g} / \mathrm{g}$ in carp, $0.41-0.52 \mu \mathrm{g} / \mathrm{g}$ in bass, and $0.28-0.62 \mu \mathrm{g} / \mathrm{g}$ channel catfish in the GR southwest of Phoenix near Station 325 (King and others, 1997). Concentrations were relatively low $(<0.06$ $\mu \mathrm{g} / \mathrm{g}$ ) in channel catfish from agricultural areas of the Lower GR (Baker and others, 1992). Concentrations from Station 323 were similar to those measured in fish from the AshurstHayden Dam (Andrews and King, 1997). Chromium concentrations were $>2.4 \mu \mathrm{g} / \mathrm{g}$ in fish from the Lower CDR near Stations 321 and 322 (King and others, 1993), and Cr was named a contaminant of concern in fish from Havasu NWR (Andrews and others, 1997). Concentrations were $0.14-1.13 \mu \mathrm{g} / \mathrm{g}$ in carp and $0.30-4.37 \mu \mathrm{g} / \mathrm{g}$ in white sucker from the Green River near the Ouray NWR (Rowland and others, 2002). Chromium concentrations in carp were $0.38-71.8 \mu \mathrm{g} / \mathrm{g}$ in the RGB (Schmitt and others, 2004) and 0.76-3.96 $\mu \mathrm{g} / \mathrm{g}$ in the CRB (Hinck and others, 2004a), and concentrations in bass were $0.71-70.1 \mu \mathrm{g} / \mathrm{g}$ in the RGB (Schmitt and others, 2004) and 0.30-3.70 $\mu \mathrm{g} / \mathrm{g}$ in the CRB (Hinck and others, 2004a). Chromium concentrations were generally lower than those from previous LRMN studies (table 13).

Eisler (1986) suggested that concentrations of $\mathrm{Cr}>4.0$ $\mu \mathrm{g} / \mathrm{g} \mathrm{dw}(1.0 \mu \mathrm{g} / \mathrm{g}$ ww assuming $75 \%$ moisture $)$ in the tissues and organs of fish and wildlife indicate environmental contamination, but the significance of such a value is unclear. Studies linking whole-body $\mathrm{Cr}$ concentrations to survival or 
growth effects in freshwater fishes were not found (Jarvinen and Ankley, 1999).

\section{Nickel}

Concentrations of Ni were $>\operatorname{LOD}(0.24-0.35 \mu \mathrm{g} / \mathrm{g})$ in only 3 of 52 samples $(6 \%)$ from three stations (table 10). Concentrations were $0.87-1.73 \mu \mathrm{g} / \mathrm{g}$, and the maximum concentration was in female carp from Station 315 (fig. 7; table 10). Mean concentrations were $>0.2 \mu \mathrm{g} / \mathrm{g}$ at Stations 315,321 , and 323 (table 11).

Nickel was not a contaminant of concern in previous CDRB investigations (Andrews and King, 1997; Andrews and others, 1997; King and others, 1993, 1997; Rowland and others, 2002; Stephens and others, 1988). Nickel concentrations in carp were $0.18-4.21 \mu \mathrm{g} / \mathrm{g}$ in the RGB (Schmitt and others, 2004) and $<0.25-0.75 \mu \mathrm{g} / \mathrm{g}$ in the CRB (Hinck and others, 2004a), and concentrations in bass were 0.23-3.29 $\mu \mathrm{g} / \mathrm{g}$ in the RGB (Schmitt and others, 2004) and <0.22-0.31 in the CRB (Hinck and others, 2004a). Studies are lacking for linkages of whole-body concentrations to effects for Ni (Jarvinen and Ankley, 1999), and tissue-based criteria for the protection of fishes and piscivorous wildlife are not available. Data for additional elements from this study are available at <http:// www.cerc.usgs.gov/data/search.htm>.

\section{Organochlorine Contaminants}

\section{DDT and its primary metabolites}

The U.S. banned the use of DDT in 1972 although concentrations of this persistent organochlorine insecticide and its metabolites remain present in the environment from historical use and as a consequence of atmospheric transport (Fernadez and Grimalt, 2003). Elevated concentrations of DDT residues are most common in cotton-growing areas of the U.S., near former sites of production and formulation, and through atmospheric transport from sites where DDT is still used (Schmitt and others, 2002). We found the parent compound, $p, p$ '-DDT, exceeded the LOD $(>0.0014 \mu \mathrm{g} / \mathrm{g})$ in 21 of 52 fish samples (40\%) from seven stations (table 14), but all concentrations of $p, p$ '-DDT were low. The maximum $p, p$ '-DDT concentration $(0.031 \mu \mathrm{g} / \mathrm{g})$ was measured in male bass at Station 325 (table 14). The major metabolite of $p, p^{\prime}$-DDT, $p, p^{\prime}$-DDE, was detected in all samples, and the maximum concentration (2.7 $\mu \mathrm{g} / \mathrm{g}$ ) was measured in male bass from Station 325 (table 14; fig. 8). Samples with concentrations $>0.5 \mu \mathrm{g} / \mathrm{g}$ included carp from Station 325 (1.3 and $1.7 \mu \mathrm{g} / \mathrm{g}$ ), bass from Station 325 (1.6 and $2.7 \mu \mathrm{g} / \mathrm{g}$ ), and channel catfish from Station 324 (0.64 and $0.78 \mu \mathrm{g} / \mathrm{g}$; fig. 8), and station means were also greatest at Stations 324 and 325 (table 15). Concentrations of $p$, p'-DDE differed significantly among stations in carp, bass, and channel catfish (table 12). Concentrations of $p, p^{\prime}$-DDE were significantly greater in bass and carp from Station 325 and channel catfish from Station 324. Mean concentrations of total DDT (p,p'- homologs) were greatest at Stations 324 and 325 (fig. 9). Concentrations of $p, p$ '-DDD from $p, p$ '-DDT breakdown and use as an insecticide were detected in 48 of 52 (92\%) samples representing all stations (table 14).

Our findings are consistent with the relatively high historical concentrations of total DDT (primarily as $p, p^{\prime}$-DDE) in fish from the intensively farmed valleys of the Lower CDR and GR (Baker and others, 1992; Clark and Krynitsky, 1983; García-Hernández and others, 2001; Kepner, 1987; King and others, 1997; Schmitt and others, 1999). Conversely, Stephens and others (1988) reported concentrations were $<$ LOD in fish from the Upper CDRB. Massive amounts of DDT (>25 kg/ha) have been applied to cotton growing regions of the Lower GR from the late 1950 s to the early 1970 s that have resulted in some of the highest reported concentrations in the U.S. (King and others, 1997). Concentrations of total DDT were $<0.05$ $\mu \mathrm{g} / \mathrm{g}$ in fish from historical NCBP sites except in fish from Yuma, Arizona (Schmitt and others, 1999), but $p, p$ '-DDE concentrations were high in carp (0.03-0.43 $\mu \mathrm{g} / \mathrm{g})$ and largemouth bass $(0.79-2.06 \mu \mathrm{g} / \mathrm{g})$ from 1976 to 1986 at this site. Concentrations of $p, p$ '-DDE in carp were $11.17 \mu \mathrm{g} / \mathrm{g}$ from Buckeye Canal, an agricultural drain, near Station 325 (King and others, 1997). Concentrations of $p, p$ '-DDE may also be hazardous to fish in Lake Mead (Bevans and others, 1996; Tuttle and Orsak, 2002).

Concentrations of $p, p$ '-DDE in carp, bass, and channel catfish measured in previous LRMN were greater than those measured in CDRB fish (table 16). In carp, concentrations were $<0.01-8.3 \mu \mathrm{g} / \mathrm{g}$ in the MRB (Schmitt and others, 2002), $0.01-0.67 \mu \mathrm{g} / \mathrm{g}$ in the RGB (Schmitt and others, 2004), and 0.01-1.1 $\mu \mathrm{g} / \mathrm{g}$ in the CRB (Hinck and others, 2004a). Concentrations in bass were $<0.01-0.53 \mu \mathrm{g} / \mathrm{g}$ in the MRB (Schmitt and others, 2002), <0.01-0.40 $\mu \mathrm{g} / \mathrm{g}$ in the RGB (Schmitt and others, 2004), and <0.01-1.2 $\mu \mathrm{g} / \mathrm{g}$ in the CRB (Hinck and others, 2004a), and concentrations in channel catfish ranged from 0.10 to $1.4 \mu \mathrm{g} / \mathrm{g}$ in the RGB (Schmitt and others, 2004).

Concentrations of total DDT in fish $>0.15 \mu \mathrm{g} / \mathrm{g}$ are potentially harmful to the brown pelican (Pelicanus occidentalis), a sensitive avian species (Anderson and others, 1975). Protective wildlife criteria as low as $0.20 \mu \mathrm{g} / \mathrm{g}$ have been suggested by Newell and others (1987). Concentrations of 1-3 $\mu \mathrm{g} / \mathrm{g}$ are potentially hazardous to most piscivorous birds (see review by Blus, 1996), and whole-body concentrations as low as 0.5 $\mu \mathrm{g} / \mathrm{g}$ have been associated with toxic effects to fish (see review by Jarvinen and Ankley, 1999). Whole-body concentrations of total DDT $<5.0 \mu \mathrm{g} / \mathrm{g}$ have reduced survival of fry or fingerlings in multiple freshwater fish species (Burdick and others, 1964; Cuerrier and others, 1967; Hopkins and others, 1969; Johnson and Pecor, 1969; Macek, 1968). Total DDT concentrations were $>1.0 \mu \mathrm{g} / \mathrm{g}$ in fish from Station 325 only (fig. 9), and concentrations were $>0.15 \mu \mathrm{g} / \mathrm{g}$ in individual samples from Stations 314, 315, 324, and 325. Concentrations of total DDT and $p, p$ '-DDE in the GR have declined over the past decade, although fish and wildlife, including migratory birds, are still at risk from current concentrations. 
Table 14. Percent of samples and stations with concentrations exceeding the limit of detection (LOD) for organochlorine chemical residues in composite samples of whole fish in the Colorado River Basin in 2003. The maximum concentrations and associated sample information (station, species, and gender) from this study are also given. ND, not detected. a Sum of $p, p^{\prime}-\mathrm{DDT}, p, p^{\prime}-\mathrm{DDE}$, and $p, p^{\prime}-\mathrm{DDD}$, with censored values represented by one half the LOD. ${ }^{\circ}$ Sum of $c i s$ - and trans-chlordanes and nonachlors; oxychlordane; heptachlor; and heptachlor epoxide, with censored values represented by one half the LOD. ${ }^{c} 1,1 a, 2,2,3,3 a, 4,5,5,5 a, 5 b, 6-d o d e c a c h l o r o-o c t a h y d r o-1,3,4-m e t h e n o-1 H-c y c l o b u t a(c d) p e n t a l e n e . ~{ }^{d}$ Sum of $\alpha-, \beta-, \gamma^{-}$, and $\delta$ hexachlorocyclohexane with censored represented by one half the LOD. NA - not applicable.

\begin{tabular}{|c|c|c|c|c|c|c|}
\hline \multirow{2}{*}{ Analyte(s) } & \multirow{2}{*}{$\begin{array}{l}\text { Samples } \\
\text { (\% of } 52 \text { ) }\end{array}$} & \multirow{2}{*}{$\begin{array}{l}\text { Stations } \\
(\% \text { of } 14)\end{array}$} & \multicolumn{4}{|c|}{ Maximum 2003 concentration } \\
\hline & & & $\mu \mathrm{g} / \mathrm{g}$ & Station & Gender & Species \\
\hline$p, p^{\prime}$-DDT & 40 & 50 & 0.031 & Arlington, AZ (325) & M & Largemouth bass \\
\hline$p, p^{\prime}-\mathrm{DDD}$ & 92 & 93 & 0.037 & Arlington, AZ (325) & M & Largemouth bass \\
\hline$p, p^{\prime}-\mathrm{DDE}$ & 100 & 100 & 2.7 & Arlington, AZ (325) & M & Largemouth bass \\
\hline Total $p, p^{\prime}$-homologs ${ }^{\text {a }}$ & NA & NA & 2.8 & Arlington, AZ (325) & M & Largemouth bass \\
\hline$o, p^{\prime}-\mathrm{DDT}$ & 38 & 71 & 0.003 & Willow Beach, AZ (320) & M & Common carp \\
\hline$o, p^{\prime}-\mathrm{DDD}$ & 38 & 50 & 0.017 & Arlington, AZ (325) & M & Common carp \\
\hline$o, p^{\prime}$-DDE & 83 & 100 & 0.017 & Arlington, AZ (325) & M & Largemouth bass \\
\hline Aldrin & 0 & 0 & NA & NA & NA & NA \\
\hline Dieldrin & 90 & 100 & 0.022 & Phoenix, AZ (324) & M & Channel catfish \\
\hline Endrin & 98 & 100 & 0.10 & Arlington, AZ (325) & M & Largemouth bass \\
\hline cis-Chlordane & 96 & 100 & 0.043 & Arlington, AZ (325) & M & Common carp \\
\hline trans-Chlordane & 79 & 93 & 0.027 & Phoenix, AZ (324) & M & Channel catfish \\
\hline cis-Nonachlor & 98 & 100 & 0.017 & Loma, CO (315) & M & Common carp \\
\hline trans-Nonachlor & 100 & 100 & 0.045 & Phoenix, AZ (324) & M & Channel catfish \\
\hline Oxychlordane & 77 & 86 & 0.011 & Phoenix, AZ (324) & M & Channel catfish \\
\hline Heptachlor epoxide & 85 & 100 & 0.004 & Loma, CO (315) & M & Common carp \\
\hline Heptachlor & 15 & 43 & 0.001 & Imperial Dam, AZ (322) & M & Largemouth bass \\
\hline Total chlordane-related residues ${ }^{\mathrm{b}}$ & NA & NA & 0.121 & Phoenix, AZ (324) & M & Channel catfish \\
\hline Toxaphene & 15 & 21 & 0.87 & Arlington, AZ (325) & M & Largemouth bass \\
\hline $\operatorname{Mirex}^{c}$ & 92 & 100 & 0.001 & San Rafael, UT (313) & M & Channel catfish \\
\hline Hexachlorobenzene (HCB) & 94 & 100 & 0.007 & Phoenix, AZ (324) & M & Channel catfish \\
\hline Pentachlorobenzene & 65 & 86 & 0.001 & Phoenix, AZ (324) & M & Channel catfish \\
\hline Pentachloroanisole & 94 & 100 & 0.021 & Gold Bar Canyon, UT (316) & M & Common carp \\
\hline alpha-HCH & 69 & 100 & 0.001 & South Cove, AZ (319) & $\mathrm{F}$ & Common carp \\
\hline beta-HCH & 62 & 79 & 0.004 & San Rafael, UT (313) & $\mathrm{F}$ & Common carp \\
\hline gamma-HCH (Lindane) & 35 & 64 & 0.008 & Phoenix, AZ (324) & M & Channel catfish \\
\hline delta-HCH & 52 & 71 & 0.003 & Phoenix, AZ (324) & M & Channel catfish \\
\hline Hexachlorocyclohexane $(\mathrm{HCH})^{d}$ & 94 & 100 & 0.015 & Phoenix, AZ (324) & M & Channel catfish \\
\hline Dacthal & 46 & 79 & 0.009 & Phoenix, AZ (324) & M & Common carp \\
\hline Endosulfan I & 21 & 50 & 0.004 & Hayden, AZ (323) & $\mathrm{F}$ & Common carp \\
\hline Endosulfan II & 46 & 64 & 0.054 & Arlington, AZ (325) & M & Common carp \\
\hline Endosulfan sulfate & 96 & 100 & 0.079 & Arlington, AZ (325) & M & Common carp \\
\hline Methoxychlor & 21 & 36 & 0.010 & Arlington, AZ (325) & M & Largemouth bass \\
\hline Total PCBs & 42 & 64 & 2.1 & Phoenix, AZ (324) & $\mathrm{F}$ & Channel catfish \\
\hline
\end{tabular}




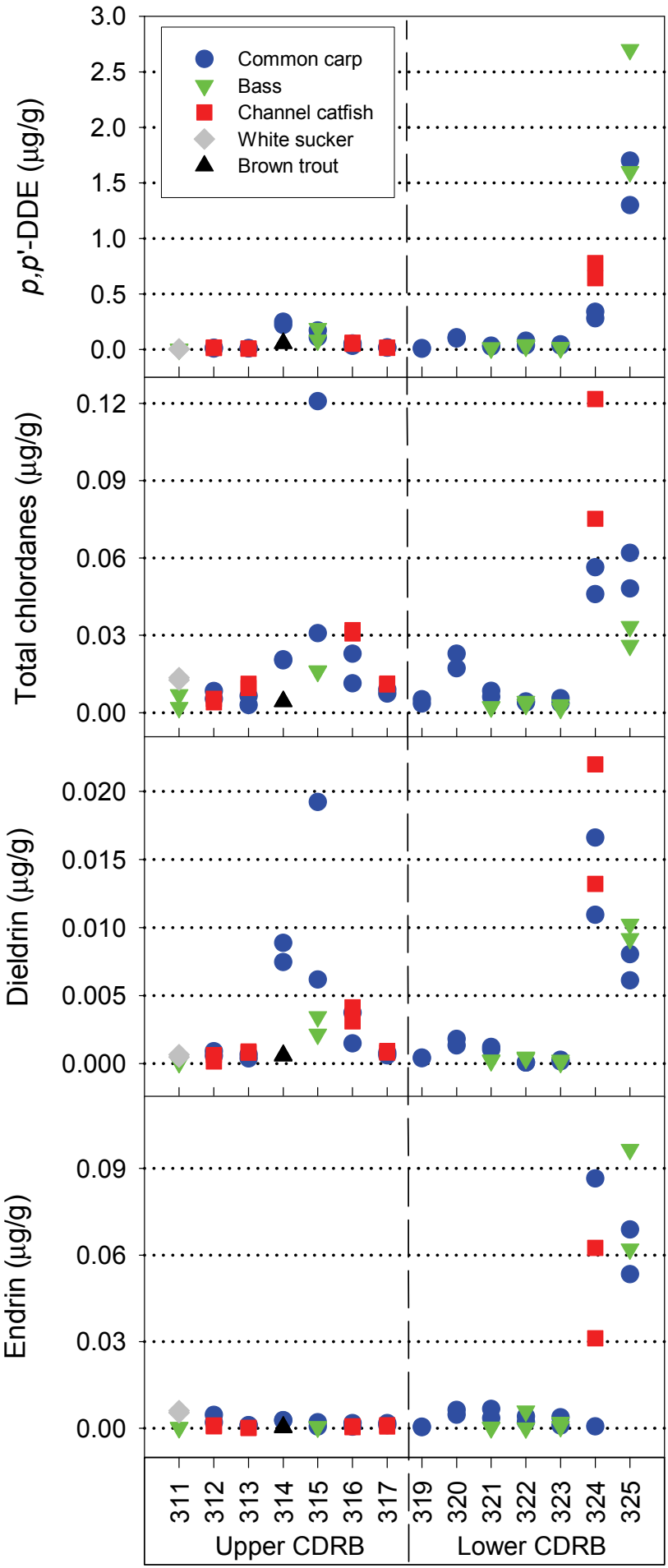

Station

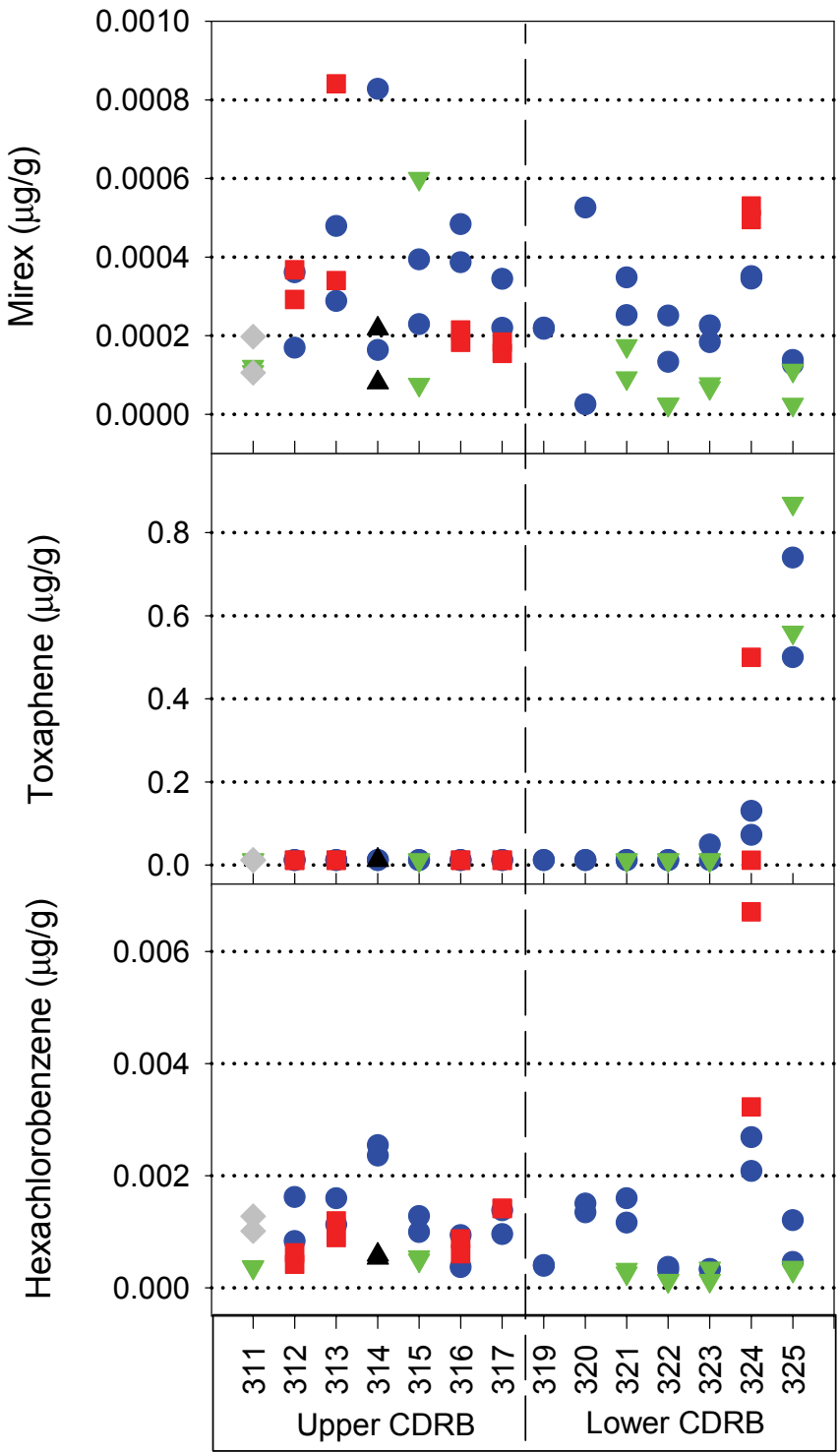

Station

Figure 8. Concentrations ( $\mu \mathrm{g} / \mathrm{g} w w)$ of banned pesticides or pesticide products including $p, p^{\prime}$-DDE, total chlordanes, dieldrin, endrin, mirex, toxaphene, and hexachlorobenzene by station and taxon in whole-body fish composite samples from the Colorado River Basin in 2003. Total chlordanes are the sum of cis- and trans-chlordanes and nonachlors, heptachlor, heptachlor epoxide, and oxychlordane. Censored values are plotted as one half the LOD. Stations are ordered from upstream to downstream and are grouped by sub-basin. See Table 2 for station descriptions. 
Table 15. Unweighted geometric mean, minimum (Min), and maximum (Max) concentrations ( $\mu \mathrm{g} / \mathrm{g}$ ww) of organochlorine chemical contaminants in fish from the Colorado River Basin in 2003. Censored values were replaced by one-half of the value for the LOD for the computation of station means, but only if at least one value exceeded LOD. Total PCBs is the sum of all congeners. Total chlordane is the sum of cis-chlordane, trans-chlordane, cis-nonachlor, trans-nonachlor, heptachlor, heptachlor epoxide and oxychlordane. The maximum geometric station mean is shown in bold for each contaminant. Stations are listed from upstream to downstream.

\begin{tabular}{|c|c|c|c|c|c|c|}
\hline Station & & $p, p^{\prime}-\mathrm{DDE}$ & Dieldrin & Total PCBs & Toxaphene & Total chlordane \\
\hline \multicolumn{7}{|l|}{ Upper Colorado River Basin } \\
\hline Lay, CO (311) & Mean & 0.003 & 0.0002 & $<0.048$ & $<0.024$ & 0.007 \\
\hline \multirow[t]{2}{*}{$n=4$} & Min & 0.001 & $<0.0002$ & $<0.048$ & $<0.024$ & 0.002 \\
\hline & $\operatorname{Max}$ & 0.006 & 0.0008 & $<0.048$ & $<0.024$ & 0.014 \\
\hline Ouray NWR, UT (312) & Mean & 0.014 & 0.0005 & $<0.048$ & $<0.024$ & 0.006 \\
\hline \multirow[t]{2}{*}{$n=4$} & Min & 0.009 & 0.0002 & $<0.048$ & $<0.024$ & 0.004 \\
\hline & Max & 0.018 & 0.0010 & $<0.048$ & $<0.024$ & 0.008 \\
\hline San Rafael, UT (313) & Mean & 0.010 & 0.0007 & $<0.048$ & $<0.024$ & 0.007 \\
\hline \multirow[t]{2}{*}{$n=4$} & Min & 0.007 & 0.0004 & $<0.048$ & $<0.024$ & 0.003 \\
\hline & Max & 0.013 & 0.0009 & $<0.048$ & $<0.024$ & 0.011 \\
\hline Delta, CO (314) & Mean & 0.116 & 0.0022 & 0.044 & $<0.024$ & 0.010 \\
\hline \multirow[t]{2}{*}{$n=4$} & Min & 0.057 & 0.0006 & $<0.048$ & $<0.024$ & 0.004 \\
\hline & $\operatorname{Max}$ & 0.250 & 0.0089 & 0.081 & $<0.024$ & 0.021 \\
\hline Loma, CO (315) & Mean & 0.131 & 0.0055 & 0.045 & $<0.024$ & 0.031 \\
\hline \multirow[t]{2}{*}{$n=4$} & Min & 0.083 & 0.0022 & $<0.048$ & $<0.024$ & 0.016 \\
\hline & Max & 0.190 & 0.0192 & 0.065 & $<0.024$ & 0.121 \\
\hline Gold Bar Canyon, UT (316) & Mean & 0.049 & 0.0029 & $<0.048$ & $<0.024$ & 0.023 \\
\hline \multirow[t]{2}{*}{$n=4$} & Min & 0.033 & 0.0015 & $<0.048$ & $<0.024$ & 0.011 \\
\hline & $\operatorname{Max}$ & 0.061 & 0.0041 & $<0.048$ & $<0.024$ & 0.032 \\
\hline Hogback Diversion, NM (317) & Mean & 0.016 & 0.0008 & 0.035 & $<0.024$ & 0.010 \\
\hline \multirow[t]{2}{*}{$n=4$} & Min & 0.015 & 0.0006 & $<0.048$ & $<0.024$ & 0.007 \\
\hline & $\operatorname{Max}$ & 0.019 & 0.0009 & 0.052 & $<0.024$ & 0.011 \\
\hline \multicolumn{7}{|l|}{ Lower Colorado River Basin } \\
\hline South Cove, AZ (319) & Mean & 0.009 & 0.0004 & $<0.048$ & $<0.024$ & 0.004 \\
\hline \multirow[t]{2}{*}{$n=2$} & Min & 0.007 & 0.0004 & $<0.048$ & $<0.024$ & 0.003 \\
\hline & $\operatorname{Max}$ & 0.012 & 0.0004 & $<0.048$ & $<0.024$ & 0.005 \\
\hline Willow Beach, AZ (320) & Mean & 0.104 & 0.0015 & 1.20 & $<0.024$ & 0.020 \\
\hline \multirow[t]{2}{*}{$n=2$} & Min & 0.099 & 0.0013 & 0.87 & $<0.024$ & 0.017 \\
\hline & $\operatorname{Max}$ & 0.110 & 0.0018 & 1.60 & $<0.024$ & 0.023 \\
\hline Needles, CA (321) & Mean & 0.021 & 0.0005 & 0.039 & $<0.024$ & 0.004 \\
\hline \multirow[t]{2}{*}{$n=4$} & Min & 0.014 & 0.0002 & $<0.028$ & $<0.024$ & 0.002 \\
\hline & $\operatorname{Max}$ & 0.034 & 0.0012 & 0.067 & $<0.024$ & 0.008 \\
\hline
\end{tabular}


Table 15. Unweighted geometric mean, minimum (Min), and maximum (Max) concentrations ( $\mu \mathrm{g} / \mathrm{g}$ ww) of organochlorine chemical contaminants in fish from the Colorado River Basin in 2003. Censored values were replaced by one-half of the value for the LOD for the computation of station means, but only if at least one value exceeded LOD. Total PCBs is the sum of all congeners. Total chlordane is the sum of cis-chlordane, trans-chlordane, cis-nonachlor, trans-nonachlor, heptachlor, heptachlor epoxide and oxychlordane. The maximum geometric station mean is shown in bold for each contaminant. Stations are listed from upstream to downstream.-Continued

\begin{tabular}{|c|c|c|c|c|c|c|}
\hline Station & & $p, p '$-DDE & Dieldrin & Total PCBs & Toxaphene & Total chlordane \\
\hline Imperial Dam, AZ (322) & Mean & 0.043 & 0.0002 & 0.038 & $<0.024$ & 0.004 \\
\hline \multirow[t]{2}{*}{$n=4$} & Min & 0.028 & $<0.0002$ & $<0.048$ & $<0.024$ & 0.003 \\
\hline & Max & 0.078 & 0.0005 & 0.067 & $<0.024$ & 0.004 \\
\hline Hayden, AZ (323) & Mean & 0.026 & 0.0002 & 0.031 & 0.017 & 0.003 \\
\hline \multirow[t]{2}{*}{$n=4$} & Min & 0.016 & $<0.0002$ & $<0.048$ & $<0.024$ & 0.002 \\
\hline & Max & 0.047 & 0.0003 & 0.070 & 0.049 & 0.006 \\
\hline Phoenix, AZ (324) & Mean & 0.467 & 0.0152 & 1.30 & 0.09 & 0.070 \\
\hline \multirow[t]{2}{*}{$n=4$} & Min & 0.280 & 0.0109 & 1.00 & $<0.024$ & 0.046 \\
\hline & Max & 0.780 & 0.0220 & 2.10 & 0.50 & 0.122 \\
\hline Arlington, AZ (325) & Mean & 1.758 & 0.0082 & 0.13 & 0.65 & 0.040 \\
\hline \multirow[t]{2}{*}{$n=4$} & Min & 1.300 & 0.0061 & 0.12 & 0.50 & 0.026 \\
\hline & Max & 2.700 & 0.0102 & 0.18 & 0.87 & 0.062 \\
\hline
\end{tabular}

Technical DDT contains $o, p$ '-DDT as an impurity (up to approximately 15\%), and residues of this compound and its metabolites also remain widespread (Schmitt and others, 1999, 2002). Concentrations of $o$, $p^{\prime}-\mathrm{DDE}(<0.00008-0.017 \mu \mathrm{g} / \mathrm{g})$, $o, p^{\prime}-\mathrm{DDD}(<0.00055-0.017 \mu \mathrm{g} / \mathrm{g})$, and $o, p^{\prime}-\mathrm{DDT}(<0.00053-$ $0.11 \mu \mathrm{g} / \mathrm{g}$ ) were greatest in male largemouth bass from Station 325 (table 14). Concentrations of $o, p$ '-DDT were generally greater in fish from the GR $(0.05-0.11 \mu \mathrm{g} / \mathrm{g})$ than all others from the CDRB $(<0.003 \mu \mathrm{g} / \mathrm{g})$. Concentrations of $o, p$ '-DDD were relatively high compared to $p, p$ '-DDD concentrations in samples from the Station 324 and 325 (Appendix 5); o, p'DDD concentrations were expected to be 10 times lower than $p, p$ '-DDD concentrations Concentrations of $o, p^{\prime}$-homologs were generally not detected or low $(\leq 0.01 \mu \mathrm{g} / \mathrm{g})$ in bass or carp from the RGB and CRB (Hinck and others, 2004a; Schmitt and others, 2004). The $o, p$ ' homologs were historically considered relatively benign, but multiple studies have found that these compounds are estrogenic (Ackerman and others, 2002; Donohoe and Curtis, 1996; Guillette and others, 1996; Metcalfe and others, 2000; Papoulias and others, 2003; Toppari and others, 1996). Dietary exposure to estrogenic chemicals including $o, p$ '-DDT and $o, p^{\prime}$-DDE produced hepatotoxicity in rainbow trout, potentially causing decreased HSI values, plasma vtg concentrations, and lipid levels (Donohoe and Curtis, 1996). Papoulias and others (2003) reported that low concentrations of $o, p^{\prime}$-DDT and $o, p$ '-DDE may interfere with the binding of natural ligands to steroid binding receptors and proteins resulting in endocrine-disrupting effects such as decreased GSI values. Conversely, Ungerer and Thomas
(1996) found that increases in $o, p$ '-DDT concentrations were associated with increased GSI values in female but not male Atlantic croaker (Micropogonias undulatus). The study concluded that $o, p$ '-DDT binds to different lipoproteins in the plasma of female fish and compartmentalizes in the oocyte (Ungerer and Thomas, 1996). However, Metcalfe and others (2000) suggested that continuous exposure to estrogenic compounds such as $o, p$-DDT must begin in ovo and continue throughout early development to affect reproductive endpoints in fish. The total risk to fish and wildlife represented by concentrations of $o, p$ '-DDT and its homologs is unknown.

\section{Chlordane and heptachlor}

Chlordane is a mixture of cyclopentadiene-derived compounds that was widely used as a soil insecticide. Concentrations of these compounds are typically greatest in fish from corn-growing regions, urban areas in the "termite belt" or southeastern U.S., and near production and formulation facilities (Schmitt and others, 1999; Schmitt, 2002). Seven chlordane-related components and metabolites were measured: cis-chlordane, trans-chlordane, cis-nonachlor, trans-nonachlor, oxychlordane, heptachlor, and heptachlor epoxide (table 14). Heptachlor epoxide, a metabolite of heptachlor, is a minor constituent of chlordane and was also used historically as an insecticide, and environmental concentrations result from both sources. Oxychlordane is a metabolite of cis-chlordane. Concentrations of oxychlordane, heptachlor, and heptachlor epoxide were low (table 14). Concentrations of cis-chlordane were >LOD in 52 of $54(96 \%)$ samples representing all sta- 


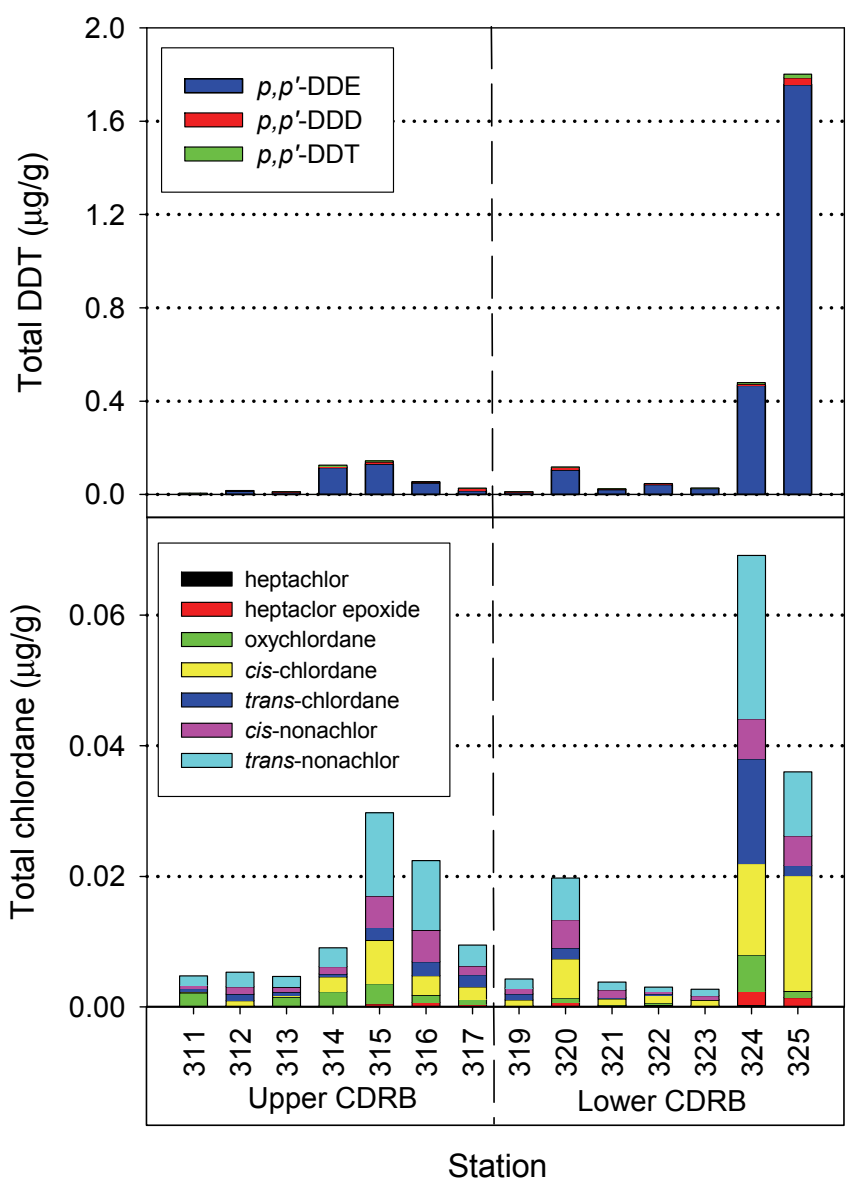

Figure 9. Unweighted geometric mean concentrations $(\mu \mathrm{g} / \mathrm{g}$ ww) of total DDT $\left(p, p^{\prime}\right.$-DDT, DDE, and DDD) and chlordanerelated compounds (cis- and trans-chlordanes and nonachlors, heptachlor, heptachlor epoxide, and oxychlordane) by station in whole-body fish composite samples from the Colorado River Basin in 2003. Censored values are represented by one half the LOD in the computation of means and totals but are not shown in the figure. Stations are ordered from upstream to downstream and are grouped by sub-basin. See Table 2 for station descriptions.

tions (table 14), and concentrations were $>0.01 \mu \mathrm{g} / \mathrm{g}$ in carp from Stations 315, 324, and 325 and channel catfish from Station 324. Trans-chlordane was detected in 41 of 52 (79\%), and concentrations were $>0.01 \mu \mathrm{g} / \mathrm{g}$ in carp from Stations 315 and 324 and channel catfish from Station 324 (table 14). Cisnonachlor was detected in most (98\%) samples, but concentrations $>0.01 \mu \mathrm{g} / \mathrm{g}$ were only measured in carp from Station 315 and channel catfish from Station 324. Trans-nonachlor was detected in all samples, and concentrations were $>0.01 \mu \mathrm{g} / \mathrm{g}$ in carp from Stations 315, 316, and 324, bass from Station 325, and channel catfish from Stations 316 and 324 (table 14). Concentrations of total chlordanes (sum of seven compounds) ranged from 0.002 to $0.12 \mu \mathrm{g} / \mathrm{g}$, and concentrations were greatest in fish from Stations 315, 316, 320, 324, and 325 (figs. 8 \& 9). Mean total chlordane concentrations were greatest at Stations $324(0.07 \mu \mathrm{g} / \mathrm{g})$ and $325(0.04 \mu \mathrm{g} / \mathrm{g}$; table 15$)$.
Trans-nonachlor, trans-chlordane, and cis-chlordane were the primary constituents of total chlordanes at these sites (fig. 9).

Historical NCBP concentrations of total chlordane were $<0.1 \mu \mathrm{g} / \mathrm{g}$ in fish from 1976 to 1986 , and most concentrations for individual constituents were $<$ LOD (Schmitt and others, 1999). Other studies reported that total chlordane concentrations were relatively low in agricultural areas of the Lower GR (Kepner, 1987; King and others, 1997) and in irrigation drainages of the Yuma Valley (Baker and others, 1992) and Middle Green River Basin (Stephens and others, 1988). Most total chlordane concentrations were $<0.1 \mu \mathrm{g} / \mathrm{g}$ in carp, bass, and channel catfish from previous LRMN investigations (Hinck and others, 2004a; Schmitt and others, 2002, 2004), but mean basin concentrations were generally lower in the CDRB than the CRB, MRB, and RGB (table 16). Total chlordane concentrations $>0.3 \mu \mathrm{g} / \mathrm{g}$ are of concern for the health of predatory fish and fish-eating birds (Eisler, 1990). Fish and wildlife are not at risk from chlordane in the CDRB.

\section{Dieldrin}

Most environmental dieldrin is present due to the breakdown of aldrin, which has not been used in the U.S. since 1974 and was not detected in CDRB samples (table 14). Concentrations of dieldrin were detected in 47 of 52 (90\%) samples representing all stations (table 14). Concentrations were $>0.01$ $\mu \mathrm{g} / \mathrm{g}$ in carp from Stations 315 and 324, bass from Station 325, and channel catfish from Station 324 (fig. 8). Trace concentrations $(0.001-0.01 \mu \mathrm{g} / \mathrm{g})$ were detected in samples from Stations 314, 315, 316, 320, and 321 (fig. 8). All mean concentrations were $\leq 0.008 \mu \mathrm{g} / \mathrm{g}$ except for Station $324(0.015$ $\mu \mathrm{g} / \mathrm{g}$; table 15$)$.

Most concentrations of dieldrin were $\leq \mathrm{LOD}(0.1 \mu \mathrm{g} / \mathrm{g})$ in carp, bass, and channel catfish from NCBP stations in the CDRB from 1976 to 1986 (Schmitt and others, 1999), and dieldrin concentrations were $\leq 0.03 \mu \mathrm{g} / \mathrm{g}$ in fish from the Yuma Valley (Baker and others, 1992). Dieldrin concentrations were $<\mathrm{LOD}(\sim 0.1 \mu \mathrm{g} / \mathrm{g})$ in fish from irrigation drainages in the Middle Green River Basin (Stephens and others, 1988). Dieldrin was also rarely detected in carp, bass, and channel catfish in the Lower GR although concentrations were 0.01-0.09 $\mu \mathrm{g} / \mathrm{g}$ in bass collected downstream of Phoenix (King and others, 1997). Previous LRMN studies from the MRB (Schmitt and others, 2002), RGB (Schmitt and others, 2004), and CRB (Hinck and others, 2004a) reported low concentrations of dieldrin in most carp $(<0.01-0.25 \mu \mathrm{g} / \mathrm{g})$, bass $(<0.01-0.08$ $\mu \mathrm{g} / \mathrm{g})$, and channel catfish $(<0.01-0.05 \mu \mathrm{g} / \mathrm{g})$. Whole-body concentrations of $0.36-2.13 \mu \mathrm{g} / \mathrm{g}$ in juvenile rainbow trout did not effect survival or growth, but concentrations of 5.65 $\mu \mathrm{g} / \mathrm{g}$ reduced survival (Shubat and Curtis, 1986; Macek and others, 1970 as cited in Jarvinen and Ankley, 1999). Dieldrin concentrations in CDRB fish samples are unlikely to represent a significant threat to either fish or piscivorous wildlife (Jarvinen and Ankley, 1999; Peakall, 1996). 


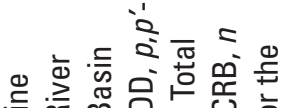

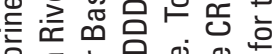

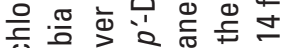

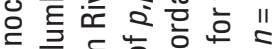

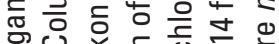

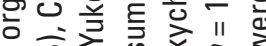
क्षे

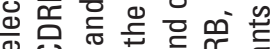

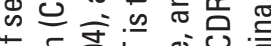

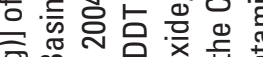
힝 w

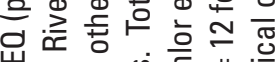

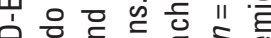
징 $\pi$

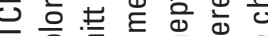

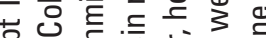
के

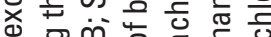
ब 잉 引言这的视 o 으동

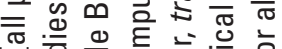

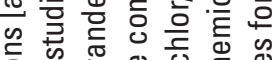

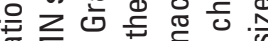
西 $\sum_{0.0}$ 는

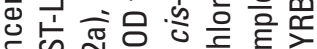

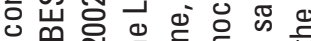
x

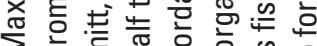
는

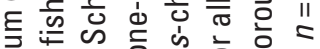

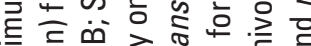

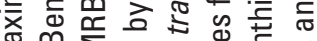
更 $\unrhd$ 心 电过

든 은 $\frac{5}{2}$ 준

도일 을 을

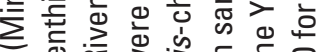

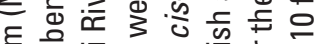

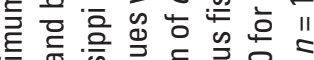

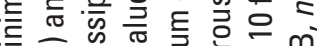

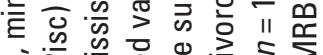

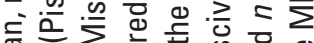
d

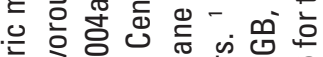
过 N 늠

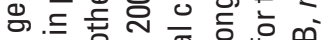

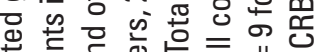

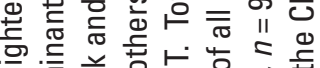

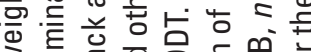

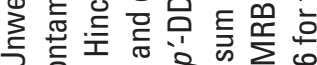

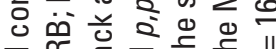

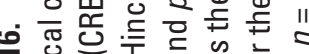

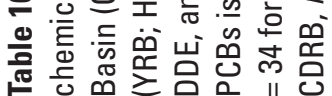

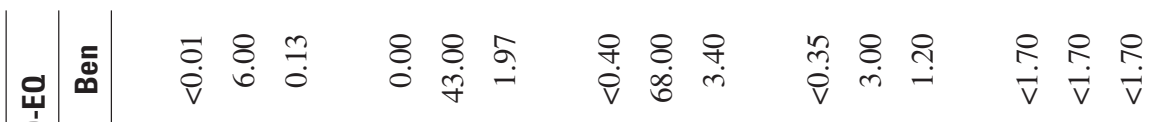

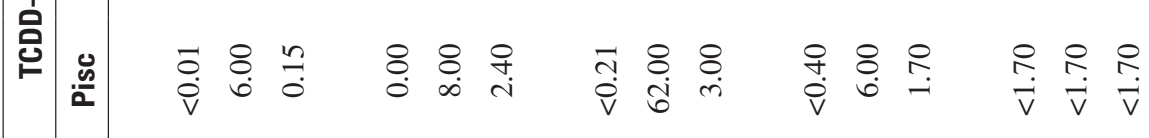

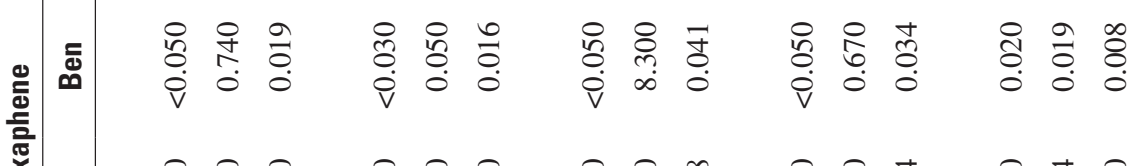

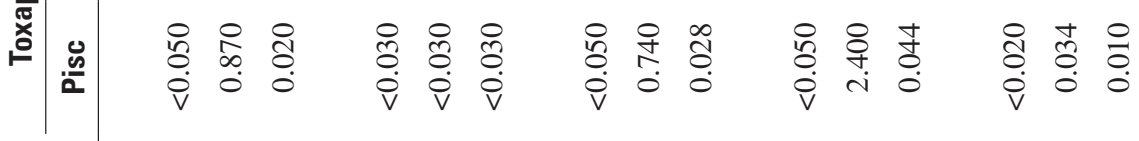

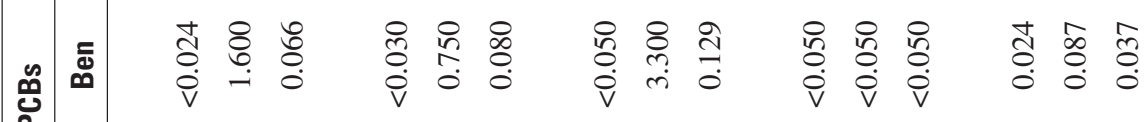

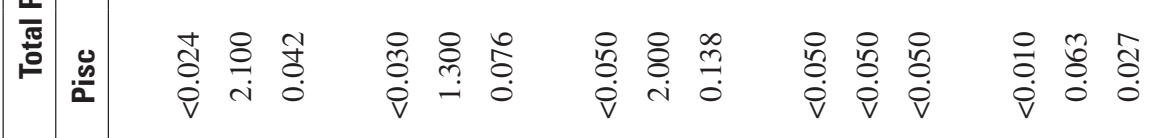

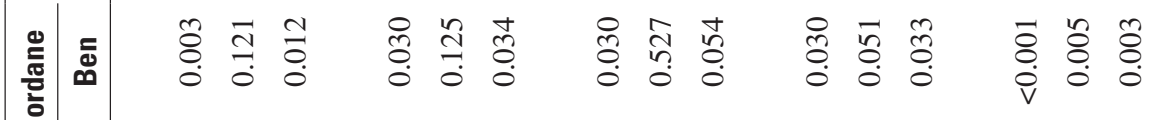

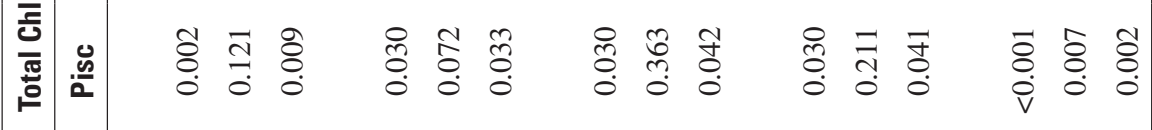
占

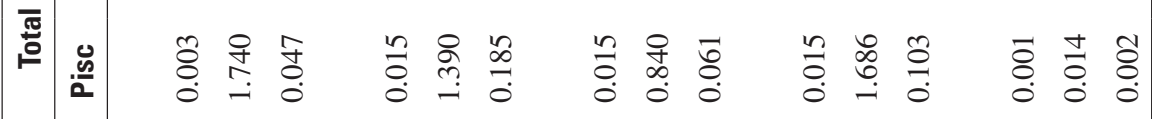

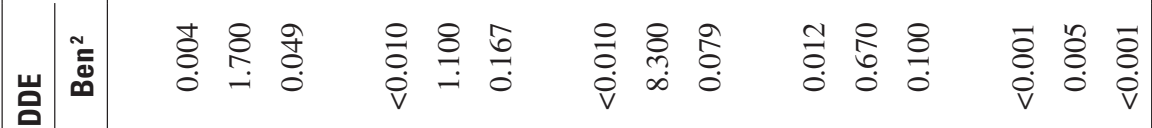

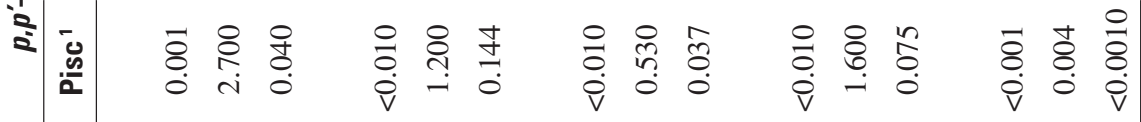

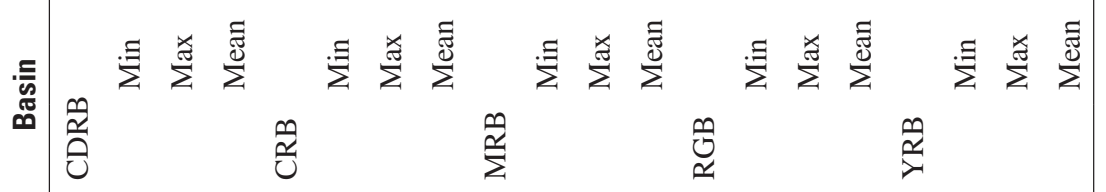




\section{Endrin}

Endrin, one of the most toxic organochlorine pesticides to fish (Johnson and Finley, 1980), was used on comparatively few crops historically. Endrin was detected in 51 of 52 (98\%) samples (table 14), and concentrations were $>0.05 \mu \mathrm{g} / \mathrm{g}$ in carp and channel catfish from Station 324 and carp and bass from Station 325 (fig. 8). Only trace endrin concentrations $(<0.01$ $\mu \mathrm{g} / \mathrm{g}$ ) were measured at historical NCBP sites in the CDRB (Schmitt and others, 1999), and concentrations in fish from the Middle Green River were <LOD (Stephens and others, 1988). Previous LRMN investigations reported non-detected or trace concentrations $(0.01 \mu \mathrm{g} / \mathrm{g})$ of endrin in carp, bass, and channel catfish (Hinck and others, 2004a; Schmitt and others, 2002, 2004). Toxicity studies documenting whole-body concentrations of endrin in fish were not found; therefore, the total risk to fish and wildlife represented by concentrations of endrin is unknown.

\section{Mirex}

Mirex was used as an insecticide to combat red imported fire ants (Solenopsis wagneri) in the southern U.S. Elsewhere, mirex was also used as a flame retardant and as a polymerizing agent (Kaiser, 1987). Mirex was detected in 48 of 52 (92\%) samples (table 14). All concentrations were $\leq 0.001 \mu \mathrm{g} / \mathrm{g}$, and the greatest concentrations were in fish from Stations 313 and 314 (fig. 8). Concentrations were not detected in NCBP samples in the CDRB (Schmitt and others, 1999). Other LRMN studies also reported low concentrations of mirex (most $<0.01$ $\mu \mathrm{g} / \mathrm{g}$; Hinck and others, 2004a, 2004b; Schmitt and others, 2002, 2004). Toxicity studies reporting whole-body concentrations of mirex in fish were not found; therefore, the total risk to fish and wildlife represented from mirex is unknown.

\section{Toxaphene}

Toxaphene was the most heavily used insecticide in the U.S. following the ban on DDT (Schmitt and Winger, 1980). Use of toxaphene in the U.S. peaked in the late 1970s, and the pesticide was subsequently banned. Historical NCBP concentrations of toxaphene in fish samples reflected use, which peaked in the mid-1970s (Schmitt and others, 1999). Although toxaphene was used mostly on cotton, this pesticide has been atmospherically transported to remote locations and residues have been detected in fish from the Arctic and the Great Lakes (Muir and others, 1999; Schmitt and others, 1999). Toxaphene was detected $(>0.024 \mu \mathrm{g} / \mathrm{g})$ in samples from Stations 323, 324, and 325 (fig. 8; table 15).

Previous studies have documented toxaphene concentrations in fish from agricultural areas of the Lower CDRB. The historical NCBP concentrations of toxaphene were generally low $(\leq 0.1 \mu \mathrm{g} / \mathrm{g})$ in carp, bass, and channel catfish although relatively high concentrations were measured in carp from the GR near Station $323(<0.01-0.8 \mu \mathrm{g} / \mathrm{g})$ and largemouth bass from the Lower CDR near Station $322(<0.01-1.0 \mu \mathrm{g} / \mathrm{g}$; Schmitt and others, 1999). Concentrations were $<$ LOD in carp from the Middle Green River Basin (Stephens and others, 1988). Relatively high toxaphene concentrations ( $>5.0$ $\mu \mathrm{g} / \mathrm{g}$ ) were reported in agricultural areas of the Lower GR in the mid-1980s (Kepner, 1987). A subsequent study reported lower concentrations in much of this area, but concentrations remained relatively high $(>1.5 \mu \mathrm{g} / \mathrm{g}$ ) in channel catfish (King and others, 1997). Toxaphene concentrations $(\leq 0.38 \mu \mathrm{g} / \mathrm{g})$ in fish from irrigation drainages in the Yuma Valley were less than protective criteria for fish $(0.40 \mu \mathrm{g} / \mathrm{g}$; Baker and others, 1992). The greatest toxaphene concentrations in the CDRB were found in cotton producing areas of the Lower GR, which is similar to the relatively high concentrations $(>2.0 \mu \mathrm{g} / \mathrm{g})$ reported in carp from cotton producing regions of the MRB (Schmitt and others, 2004). Total toxaphene concentrations were generally greater in CDRB fish than those from the RGB and YRB (table 16).

Acute and chronic effects of toxaphene on freshwater fish have been reported at whole-body concentrations $\geq 0.4$ $\mu \mathrm{g} / \mathrm{g}$ (Eisler and Jacknow, 1985; Jarvinen and Ankley, 1999). Jarvinen and Ankley (1999) cited a number of laboratory studies on the acute and chronic effects of toxaphene. Adult brook trout containing whole-body concentrations of $0.4 \mu \mathrm{g} / \mathrm{g}$ produced eggs with reduced viability, and lake trout (Salvelinus namaycush) and white sucker containing 0.035-0.203 $\mu \mathrm{g} / \mathrm{g}$ also produced eggs with reduced viability (Mayer and others, 1975). Survival and growth of several freshwater fish species at various life stages were reduced at concentrations $>0.90$ $\mu \mathrm{g} / \mathrm{g}$ (Mayer and others, 1975, 1978). Concentrations of toxaphene were $>0.4 \mu \mathrm{g} / \mathrm{g}$ in fish from Stations 324 and 325. Fish and wildlife from these sites may be at risk from toxaphene.

\section{Hexachlorobenzene (HCB)}

HCB was produced for use as a fungicide and was a byproduct of the production of other chlorinated hydrocarbons. This compound is less toxic to fish than many other persistent organochlorines but contains toxic impurities including polychlorinated dibenzo- $p$-dioxins and polychlorinated dibenzo$p$-furans (Schmitt and others, 1999; Villanueva and others, 1974). HCB was detected at trace concentrations in most samples (94\%; table 14). The greatest concentrations $(>0.002$ $\mu \mathrm{g} / \mathrm{g}$ ) were measured in carp from Stations 314 and 324 and channel catfish from Station 324 (fig. 8). Historical NCBP concentrations of HCB were $<0.01 \mu \mathrm{g} / \mathrm{g}$ (Schmitt and others, 1999), and previous LRMN investigations generally reported concentrations $\leq 0.01 \mu \mathrm{g} / \mathrm{g}$ in carp, bass, and channel catfish (Hinck and others, 2004a; Schmitt and others, 2002, 2004). Concentrations of $\mathrm{HCB}$ were $\leq 27 \mu \mathrm{g} / \mathrm{g}$ in whole fish from monitoring studies across the U.S. (Nowell and others, 1999). Protective criteria for HCB are limited. Concentrations as low as $0.33 \mu \mathrm{g} / \mathrm{g}$ in whole fish have been suggested to protect piscivorous wildlife (Newell and others, 1987), although HCB concentrations in CDRB fish were well below this benchmark. 


\section{Pentachlorobenzene}

Pentachlorobenzene is used as a precursor in the synthesis of the fungicide pentachloronitrobenzene and as a fire retardant. Pentachlorobenzene can enter aquatic systems through industrial discharge and as a degradation product of other organochlorine compounds such as hexachlorobenzene (Barber and others, 1997). Pentachlorobenzene was detected in 34 of 52 samples (65\%; table 14), but concentrations were $<0.0002 \mu \mathrm{g} / \mathrm{g}$ in most samples (fig. 10). Concentrations were $0.00022-0.00041 \mu \mathrm{g} / \mathrm{g}$ in samples from Station 325 and $0.00041-0.00089 \mu \mathrm{g} / \mathrm{g}$ in samples from Station 324 (fig. 10). Histological lesions in the kidney, liver, and thyroid have been associated with pentachlorobenzene exposure in mice and rats (McDonald, 1991). The risk of pentachlorobenzene to fish and wildlife in the CDRB is unknown.

\section{Pentachloroanisole (PCA)}

PCA, a metabolite of the wood preservative pentachlorophenol (PCP), is toxic and potentially carcinogenic (National Research Council of Canada (NRCC), 1982; Schmitt and others, 1999). Early formulations of PCP contained chlorinated dioxins and other toxic impurities (Schmitt and others, 1999). PCA was detected in 49 of 52 samples (94\%; table 14), and concentrations were $>0.01 \mu \mathrm{g} / \mathrm{g}$ in carp from Stations 312 and 316 and channel catfish from Station 324 (fig. 10). Concentrations of PCA were $\leq \mathrm{LOD}(0.005 \mu \mathrm{g} / \mathrm{g})$ in all NCBP samples from the CDRB (Schmitt and others, 1999). The risk of PCA to fish and wildlife in the CDRB is unknown.

\section{Hexachlorocyclohexane ( $\mathrm{HCH})$}

Four HCH isomers $(\alpha-, \beta-, \gamma-, \delta-\mathrm{HCH})$ were measured in the CDRB samples. Although a mixture of isomers was historically used on cotton and other crops in the U.S., only $\gamma$ $\mathrm{HCH}$ (lindane) is still used in North America for some agricultural and domestic applications. However, lindane is not heavily used in the CDRB (USGS, 2003). HCH isomers, which are relatively short-lived, were detected at trace concentrations in most samples (94\%; table 14). $\gamma$-HCH concentrations were $>0.004 \mu \mathrm{g} / \mathrm{g}$ in all samples from Station 324 (fig. 10). Concentrations of $\alpha$ - and $\gamma$ - HCH were $\leq \mathrm{LOD}(0.01 \mu \mathrm{g} / \mathrm{g})$ in most samples collected by the NCBP (Schmitt and others, 1999) and previous LRMN studies (Hinck and others, 2004a, 2004b; Schmitt and others, 2002, 2004). $\gamma$-HCH concentrations were $\leq 0.12 \mu \mathrm{g} / \mathrm{g}$ in whole fish from monitoring studies across the U.S. (Nowell and others, 1999). Histopathological alterations in the gill, liver, and kidney of freshwater fish have been associated with $\gamma-\mathrm{HCH}$ contamination (Ortiz and others, 2003). Concentrations of $\gamma-\mathrm{HCH}<0.10 \mu \mathrm{g} / \mathrm{g}$ in whole fish have been suggested to protect piscivorous wildlife (Newell and others, 1987). Concentrations in CDRB fish were well below this benchmark.

\section{Dacthal}

Dacthal remains registered as a broad-spectrum herbicide for use on ornamental plants, turf, and vegetable and field crops (Cox, 1991; Schmitt and others, 1999) and is heavily used in the GRB (USGS, 2003). The technical product of the dacthal can contain 2,3,7,8-TCDD and HCB as impurities (Cox, 1991). Dacthal was detected in 24 of 52 samples (46\%; table 14), and similar to $\gamma-\mathrm{HCH}$, dacthal concentrations were greatest $(0.005-0.009 \mu \mathrm{g} / \mathrm{g}$ ) in fish from Station 324 (fig. 10). Dacthal concentrations were $\leq 0.01-0.06 \mu \mathrm{g} / \mathrm{g}$ in NCBP samples from the CDRB (Schmitt and others, 1999). The risk of dacthal to fish and wildlife in the CDRB is unknown.

\section{Endosulfan}

Endosulfan is a broad spectrum insecticide used on a wide variety of vegetables, fruits, cereal grains, cotton, and ornamental plants and is heavily used in the Lower CDRB (USGS, 2003). Technical-grade endosulfan contains two pure isomers, endosulfan I and II. Endosulfan sulfate is a reaction product of technical endosulfan and can be found in organisms as a result of oxidation of endosulfan I and II (Agency for Toxic Substances and Disease Registry (ATSDR), 2000). Most endosulfan I concentrations were $<0.001 \mu \mathrm{g} / \mathrm{g}$, and the greatest concentrations were in carp from Stations 316 and 323 (fig. 10). Endosulfan II was detected in 24 of 52 samples (46\%; table 14), and concentrations were $<0.01 \mu \mathrm{g} / \mathrm{g}$ in all samples except those from Station 325 (fig. 10). Endosulfan sulfate was detected in most (96\%) samples, and like endosulfan II, the greatest concentrations $(>0.02 \mu \mathrm{g} / \mathrm{g})$ were in fish from Station 325 (fig. 10). Endosulfan concentrations were $\leq 0.17 \mu \mathrm{g} / \mathrm{g}$ in whole fish from monitoring studies across the U.S. (Nowell and others, 1999). Amphibians, fish, birds, and mammals treated with endosulfan exhibited developmental and reproductive effects typically associated with endocrine disrupting chemicals in previous studies (Dutta and others, 2006; USEPA, 2002). Dutta and others (2006) reported that significant damage to testicular tissue in adult bluegill after exposure to endosulfan may have deleterious effects on spermatogenesis and male fertility. Endosulfan exposure impaired genital tract development in birds (30-120 $\mu \mathrm{g} / \mathrm{g})$ and reduced hormone levels and sperm production in mammals (15-75 $\mu \mathrm{g} / \mathrm{g}$; USEPA, 2002). Effects in fish were observed at much lower concentrations, and growth and survival were the most sensitive endpoints (USEPA, 2002). Reproductive effects including decreased GSI, reduced oocyte size, and increased oocyte atresia were documented in tilapia (Sarotherodon mossambicus) after exposure to endosulfan $(0.001 \mu \mathrm{g} / \mathrm{g}$; Shukla and Pandey, 1986). Endosulfan concentrations in fish from Stations 316, 323, 324, and 325 exceeded this threshold.

\section{Methoxychlor}

Methoxychlor, a derivative of DDT, is an insecticide used on field crops, vegetables, fruits, stored grain, livestock, and domestic pets (ATSDR, 2002). Historical pesticide applica- 


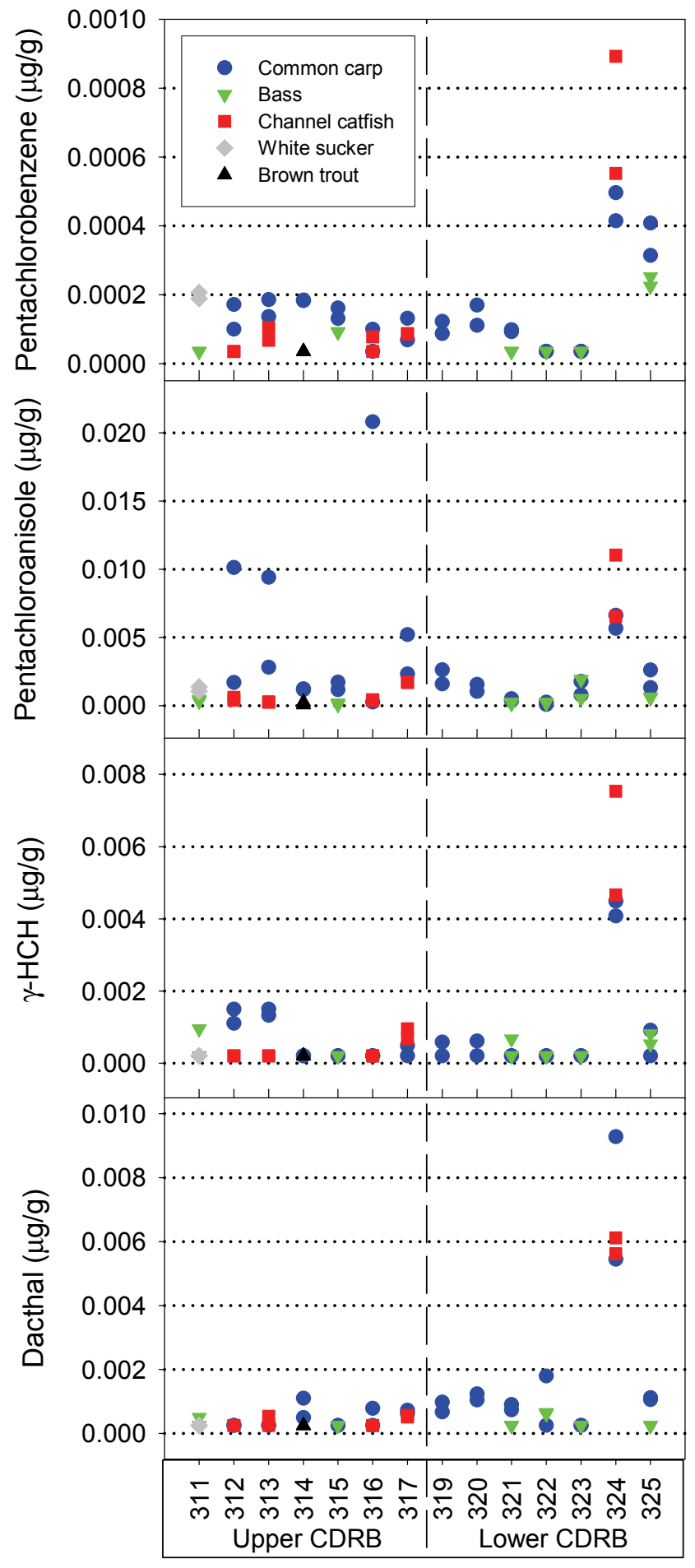

Station

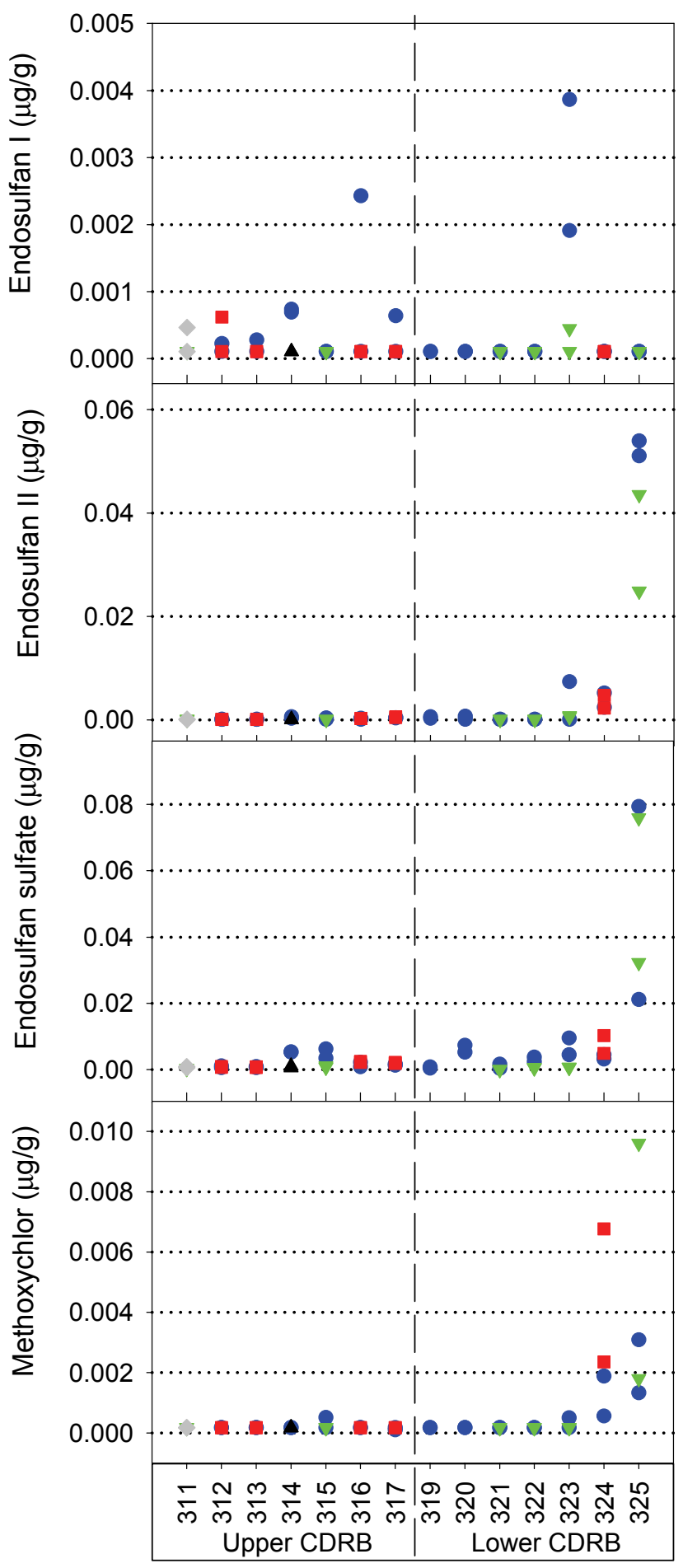

Station

Figure 10. Concentrations ( $\mu \mathrm{g} / \mathrm{g} \mathrm{ww})$ of unlisted or restricted use pesticides or pesticide products including pentachlorobenzene, pentachloroanisole, $\lambda$-BHC (lindane), dacthal, endosulfan I, endosulfan II, endosulfan sulfate, and methoxychlor by station and taxon in whole-body fish composite samples from the Colorado River Basin in 2003. Censored values are plotted as one half the LOD. Stations are ordered from upstream to downstream and are grouped by sub-basin. See Table 2 for station descriptions. 
tion records indicate that methoxychlor is not heavily used in the CDRB (USGS, 2003). Methoxychlor can bioaccumulate in fish, insects, and mammals although it is not as persistent as DDT. Methoxychlor was detected in 11 of 52 samples (21\%; table 14), and concentrations were $<0.001 \mu \mathrm{g} / \mathrm{g}$ in most samples (fig. 10). Like many of the other pesticides measured in this study, methoxychlor concentrations were greatest (>0.002 $\mu \mathrm{g} / \mathrm{g})$ in fish from Stations 324 and 325 (fig. 10). Methoxychlor can be weakly estrogenic in fish although not all the effects of methoxychlor in aquatic wildlife are mediated through the estrogen receptor (ATSDR, 2002; Versonnen and others, 2004). Methoxychlor concentrations were low in CDRB fish, but the risk of methoxychlor exposure to fish and wildlife in the CDRB is unknown.

\section{Total PCBs, H4IIE-Derived Dioxin Equivalents and Ethoxyresorufin O-Deethylase (EROD) Activity}

\section{Total PCBs}

PCBs, mixtures of 209 chlorinated compounds, were used as coolants and lubricants in electrical capacitors and transformers, for pressure treating lumber, and paper manufacturing until banned in the U.S. in 1977. Total PCBs concentrations were $>$ LOD $(0.048 \mu \mathrm{g} / \mathrm{g})$ in 22 of 52 samples $(42 \%)$ from nine stations (table 14). Concentrations were 0.05-2.1 $\mu \mathrm{g} / \mathrm{g}$, with the maximum concentration in female channel catfish from Station 324 (fig. 11; table 14). Concentrations were relatively high $(0.8 \mu \mathrm{g} / \mathrm{g})$ in carp from Stations 320 and 324 and channel catfish from Station 324 (fig. 11), and mean concentrations were greatest at Stations $320(1.2 \mu \mathrm{g} / \mathrm{g})$ and 324 (1.3 $\mu \mathrm{g} / \mathrm{g}$; table 15$)$. Concentrations of PCBs were significantly greater in carp from Stations 320 and 324 and channel catfish from Station 324; concentrations did not differ significantly among stations in bass (table 12).

Previous studies reported low PCB concentrations in the CDRB. Concentrations (as Aroclor mixtures 1248, 1254, $1260)$ at NCBP sites were historically $<\operatorname{LOD}(0.1 \mu \mathrm{g} / \mathrm{g})$ in the CDRB (Schmitt and others, 1999). Aroclor concentrations $<0.1 \mu \mathrm{g} / \mathrm{g}$ were reported in carp from the CDR near Stations 312, 321, and 322 in previous studies (Radtke and others, 1988; Stephens and others, 1988). King and others (1997) measured total PCBs in carp $(<0.05-0.65 \mu \mathrm{g} / \mathrm{g})$, bass $(<0.05-$ $0.70 \mu \mathrm{g} / \mathrm{g})$, and channel catfish $(<0.05-0.17 \mu \mathrm{g} / \mathrm{g})$ in the GR and concluded that concentrations were generally greatest downstream of the urban and industrial areas of Phoenix. Concentrations of PCBs were $<0.05-3.3 \mu \mathrm{g} / \mathrm{g}$ in carp and $0.05-2.0 \mu \mathrm{g} / \mathrm{g}$ in bass in the MRB (Schmitt and others, 2002), $<0.03-0.45 \mu \mathrm{g} / \mathrm{g}$ in carp and $<0.03-0.64$ in bass in the CRB (Hinck and others, 2004a), and were $<$ LOD $(<0.05 \mu \mathrm{g} / \mathrm{g})$ in the RGB (Schmitt and others, 2004). Total PCBs concentrations in CDRB fish were similar to those from other LRMN studies (table 16).

The New York State Department of Environmental Conservation (NYSDEC) wildlife guideline for total PCBs in fish is $0.11 \mu \mathrm{g} / \mathrm{g}$ (Newell and others, 1987), a concentration exceeded by all samples from Stations 320, 324, and 325 (fig. 11). The toxicity of individual PCB congeners ranges over several orders of magnitude (Ahlborg and others, 1994; van den Berg and others, 1998) and varies with the endpoint being considered (Hansen, 1998). Survival of fry decreased at approximately $5 \mu \mathrm{g} / \mathrm{g}$ of Aroclor 1254 in several laboratory studies (Hansen and others, 1973; Schimmel and others, 1974 as cited in Monosson, 2000). Concentrations of PCBs exceeding $100 \mu \mathrm{g} / \mathrm{g}$ in fish tissues can affect reproduction in females or be lethal, and concentrations of $50 \mu \mathrm{g} / \mathrm{g}$ can reduce growth and survival in offspring (Niimi (1996) as cited in Beyer and others, 1996). These concentrations may be lower in more sensitive fish species (Niimi, 1996). Inferior reproductive performance and offspring survival were found in mink fed Great Lakes fish or fish products with PCB concentrations of 0.48 $\mu \mathrm{g} / \mathrm{g}$ (Hornshaw and others, 1983). Concentrations of PCBs in CDRB fish were generally low, but concentrations in fish from Stations 320 and 324 were elevated and could be a risk to piscivorous wildlife.

\section{H4IIE Bioassay}

TCDD-EQs were generally low and detected in only 6 of 52 samples (12\%) from three stations (fig. 11). Concentrations of TCDD-EQs were $>2 \mathrm{pg} / \mathrm{g}$ in male channel catfish from Station 316, male carp from Station 320, and carp and channel catfish from Station 324. Relatively high PCB concentrations were also measured in samples from Station 324 (fig. 11).

Previous studies have examined TCDD-EQ concentrations in fish, but data for CDRB fish is limited. The dietary toxicity threshold for TCDD is $4.4 \mathrm{pg} / \mathrm{g}$ in mammals (Heaton and others, 1995; Tillitt and others, 1996) and 5 pg/g in avian wildlife (Nosek and others, 1992). Most concentrations in CDRB fish were similar to those reported in fish from reference sites in previous studies (Giesy and others, 1995; van den Heuvel and others, 1995). As a comparison, TCDD-EQ concentrations $\geq 60 \mathrm{pg} / \mathrm{g}$ were reported in the MRB, and in that basin those samples with concentrations $\geq 20 \mathrm{pg} / \mathrm{g}$ were widespread (Schmitt and others, 2002). TCDD-EQ concentrations were generally low $(<8 \mathrm{pg} / \mathrm{g})$ in carp and bass from the RGB and CRB (Hinck and others, 2004a; Schmitt and others, 2004). No CDRB sample approached $30 \mathrm{pg} / \mathrm{g}$, which is the threshold for toxic effects in fish (Walker and others, 1996; Whyte and others, 2004). TCDD and octochlorodibenzo- $p$-dioxin were frequently detected in sediments from Lake Mead, and maximum concentrations ( $>20 \mathrm{pg} / \mathrm{g}$ ) were measured in Las Vegas Bay (Covay and Beck, 2001). TCDD-EQ concentrations were relatively low in fish near Lake Mead (Station 319 and 320) in 2003 samples. The TCDD-EQs in fish from Station 324 were exceeded toxicity thresholds; therefore, piscivorous wildlife from this area may be at risk from dioxin-like compounds. 


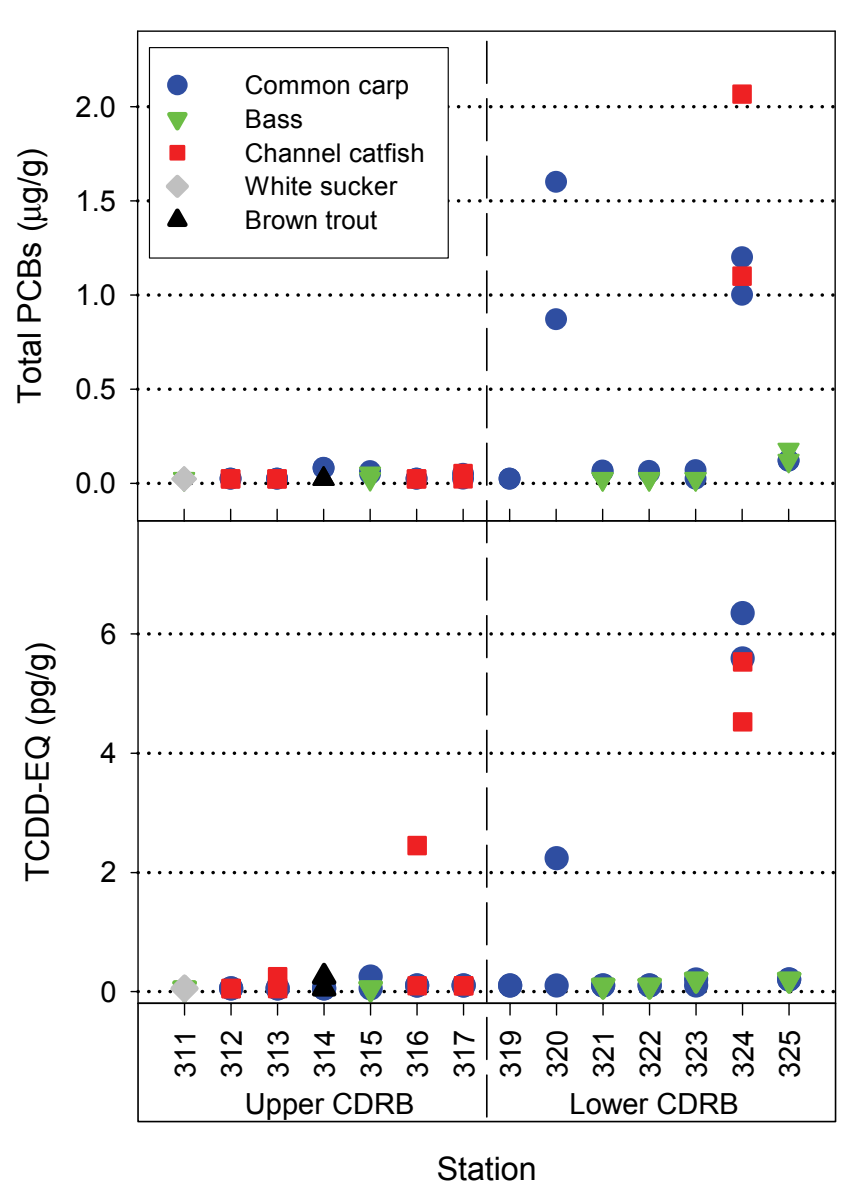

Figure 11. Concentrations of total PCB $(\mu \mathrm{g} / \mathrm{g} w w)$ and H4IIE bioassay-derived TCDD-EO (pg/g) by station and taxon in wholebody fish composite samples from the Colorado River Basin in 2003. Stations are ordered from upstream to downstream and are grouped by sub-basin. See Table 2 for station descriptions.

\section{Ethoxyresorufin 0-Deethylase (EROD) Activity}

Many factors including species, gender, and gonadal stage affect hepatic EROD activity (Whyte and others, 2000). An ANOVA model which included station (location), gender, gonadal stage, and their interactions was significant in carp $\left(F_{41,207}=3.45, P<0.01\right)$ and bass $\left(F_{23,92}=3.78, P<0.01\right)$, but not channel catfish $\left(F_{21,63}=1.17, P>0.05\right.$; Appendix 6$)$. Genders were analyzed and reported separately in all three taxa to maintain comparability with data from previous LRMN studies and the scientific literature.

\section{EROD in Carp}

Mean EROD activity was greatest $(9.05 \mathrm{pmol} / \mathrm{min} / \mathrm{mg})$ in female carp from Station 324, with individual activities ranging from 1.67 to $44.4 \mathrm{pmol} / \mathrm{min} / \mathrm{mg}$ (fig. 12; table 17). Other station means were $\leq 4.37 \mathrm{pmol} / \mathrm{min} / \mathrm{mg}$. Schlenk and others (1996) determined basal EROD activity in carp from uncontaminated sites to be $0-5 \mathrm{pmol} / \mathrm{min} / \mathrm{mg}$, which is similar to basal activity ( $0-4 \mathrm{pmol} / \mathrm{min} / \mathrm{mg}$ ) determined for carp by
Schmitt and others (2002). Hepatic EROD activities were $>5 \mathrm{pmol} / \mathrm{min} / \mathrm{mg}$ in individual female carp from all stations except Stations 315, 317, 322, and 323, but activities $>10$ $\mathrm{pmol} / \mathrm{min} / \mathrm{mg}$ in individual females were rare (fig. 12).

Mean EROD activity was greatest $(10.7 \mathrm{pmol} / \mathrm{min} / \mathrm{mg})$ in male carp from Station 324, with individual activities ranging from 5.04 to $41.7 \mathrm{pmol} / \mathrm{min} / \mathrm{mg}$ (fig. 12). Other station means ranged from $1.22 \mathrm{pmol} / \mathrm{min} / \mathrm{mg}$ at Station 322 to $8.79 \mathrm{pmol} /$ $\mathrm{min} / \mathrm{mg}$ at Station 313. Individual activities exceeded basal levels (25 pmol/min/mg; Schlenk and others, 1996; Schmitt and others, 2002) in male carp from several stations, and activity in males from Stations 313, 315, 316, 317, 320, 324, and $325 \mathrm{was}>10 \mathrm{pmol} / \mathrm{min} / \mathrm{mg}$ (fig. 12).

Hepatic EROD activity in carp was measured in other studies including previous LRMN investigations. However, EROD studies for carp in the CDRB were not found. Mean EROD activity in female carp from the CDRB (0.67-9.05 $\mathrm{pmol} / \mathrm{min} / \mathrm{mg}$ ) were similar to those from the RGB $(0.25-16.8$ $\mathrm{pmol} / \mathrm{min} / \mathrm{mg}$; Schmitt and others, 2004) and CRB (0.27$10.3 \mathrm{pmol} / \mathrm{min} / \mathrm{mg}$; Hinck and others, 2004a). Mean EROD activity in male carp was $0.34-32.6 \mathrm{pmol} / \mathrm{min} / \mathrm{mg}$ in the RGB (Schmitt and others, 2004) and 0.89-10.6 pmol $/ \mathrm{min} / \mathrm{mg}$ in the CRB (Hinck and others, 2004a), which were similar to those in the CDRB (1.22-10.7 pmol $/ \mathrm{min} / \mathrm{mg})$. In laboratory studies, EROD activities were 7.1-25 pmol/min/mg in reference juvenile carp (Kosmala and others, 1998; Taysee and others, 1998; Marionnet and others, 1997, 1998) and 2.7-41.9 pmol/ $\mathrm{min} / \mathrm{mg}$ in reference adult carp (Deér and others, 1996; Solé and others, 2000). Overall, mean hepatic EROD activity was generally highest in carp from Station 324. Relatively high PCB and TCDD-EQ concentrations, which are known AhR agonists, were also measured in carp from Station 324.

\section{EROD in bass}

Hepatic EROD activity was generally greater in bass than carp. Mean EROD activity was greatest $(13.2 \mathrm{pmol} / \mathrm{min} / \mathrm{mg})$ in female bass from Station 312, with individual activities ranging from 0.03 to $66.1 \mathrm{pmol} / \mathrm{min} / \mathrm{mg}$ (fig. 12; table 17). Other station means ranged from $2.50 \mathrm{pmol} / \mathrm{min} / \mathrm{mg}$ at Station 323 to $11.6 \mathrm{pmol} / \mathrm{min} / \mathrm{mg}$ at Station 315 (table 17). Adams and others (1994) determined basal EROD activity for female bass to be $0-5 \mathrm{pmol} / \mathrm{min} / \mathrm{mg}$, which is less than basal EROD activity $(0-16 \mathrm{pmol} / \mathrm{min} / \mathrm{mg})$ determined for female bass from the MRB (Schmitt and others, 2002). Activities $>16 \mathrm{pmol} /$ $\mathrm{min} / \mathrm{mg}$ were measured in fish from Stations 312, 315, 321, and 325 .

Mean EROD activity was greatest $(61.2 \mathrm{pmol} / \mathrm{min} / \mathrm{mg})$ in male bass from Station 312, and individual activities ranged from 39.8 to $104.5 \mathrm{pmol} / \mathrm{min} / \mathrm{mg}$ (fig. 12; table 17). Other station means were $\leq 23.4 \mathrm{pmol} / \mathrm{min} / \mathrm{mg}$ (table 17). EROD activities in male bass were greater in bass from the Upper CDRB than those from the Lower CDRB (fig. 12).

Hepatic EROD activity in bass has been reported by previous LRMN investigations and other studies, but EROD data specific to the CDRB were not found. Adams and others 


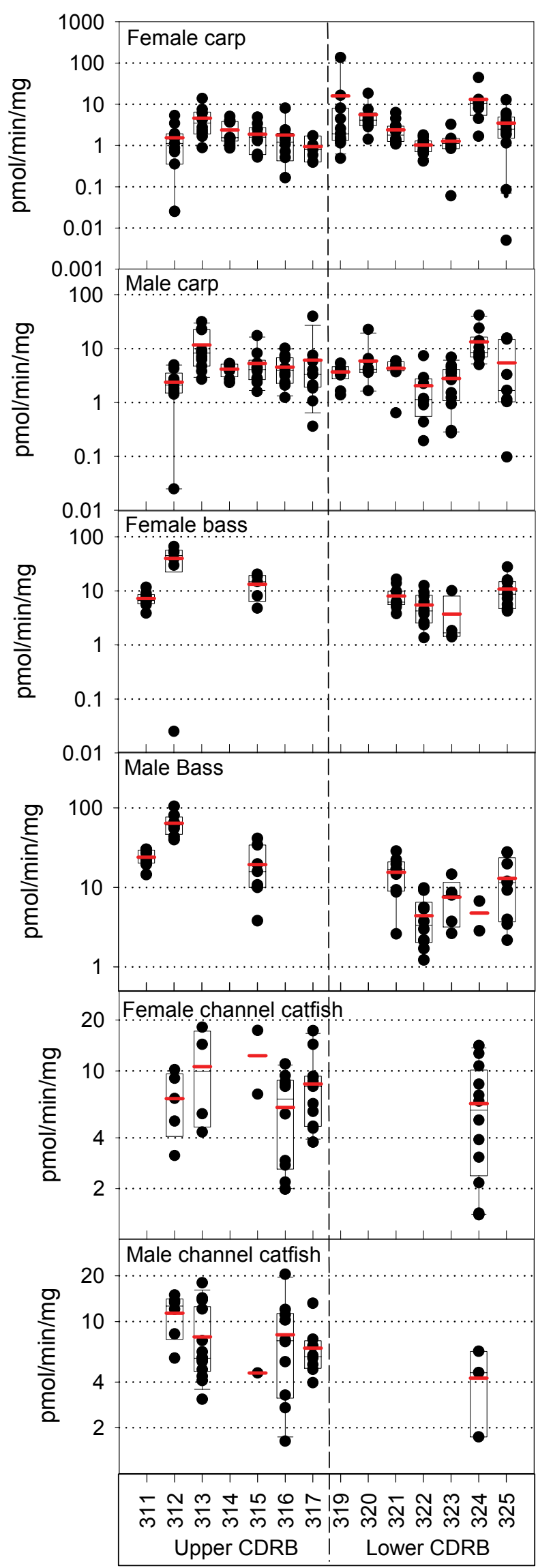

Station
(1994) determined basal EROD activity for male bass to be $0-17 \mathrm{pmol} / \mathrm{min} / \mathrm{mg}$, which is slightly less than basal EROD activity (0-22 $\mathrm{pmol} / \mathrm{min} / \mathrm{mg}$ ) determined for male bass by Schmitt and others (2002). Mean EROD activities in female bass from the CDRB (2.50-13.2 $\mathrm{pmol} / \mathrm{min} / \mathrm{mg}$ ) were lower than those from the RGB (21.3-108 pmol/min/mg; Schmitt and others, 2004) and CRB (5.21-40.4 pmol/min/mg; Hinck and others, 2004a). In male bass, mean EROD activities were 17.0-75.9 $\mathrm{pmol} / \mathrm{min} / \mathrm{mg}$ in the RGB (Schmitt and others, 2004) and 6.9-68.3 pmol/min/mg in the CRB (Hinck and others, 2004a), which were also similar to those in the CDRB (6.70-61.2 $\mathrm{pmol} / \mathrm{min} / \mathrm{mg}$ ). Activity was $>22 \mathrm{pmol} / \mathrm{min} / \mathrm{mg}$ in bass from Stations 311, 312, 315, 321, and 325. Overall, mean hepatic EROD activity was generally highest in bass from Station 312. PCB and TCDD-EQ concentrations were low in bass from Station 312, which indicates induced hepatic EROD activity may have been caused by another AhR agonist (for example, PAH).

\section{EROD in channel catfish}

Hepatic EROD activity in channel catfish was similar to those in bass. Mean activity was greatest (11.2 pmol/min $/ \mathrm{mg})$ in female channel catfish $(n=2)$ from Station 315 (fig. 12; table 17). Other station means ranged from $5.08 \mathrm{pmol} / \mathrm{min} / \mathrm{mg}$ at Station 316 to $8.90 \mathrm{pmol} / \mathrm{min} / \mathrm{mg}$ at Station 313 (table 17). Mean EROD activity in male channel catfish was comparable to females with the greatest activity $(10.8 \mathrm{pmol} / \mathrm{min} / \mathrm{mg})$ in males from Station 312, and other station means were $<6.9$ $\mathrm{pmol} / \mathrm{min} / \mathrm{mg}$ (fig. 12; table 17).

Hepatic EROD activity was measured in channel catfish from the MRB and RGB. Mean EROD activities in RGB channel catfish were 12.2-40.6 pmol $/ \mathrm{min} / \mathrm{mg}$ in females, 17.5 $20.3 \mathrm{pmol} / \mathrm{min} / \mathrm{mg}$ in males, and $14.1-38.9 \mathrm{pmol} / \mathrm{min} / \mathrm{mg}$ in juveniles (Schmitt and others, 2004). Activities were generally lower $(0.4-14.2 \mathrm{pmol} / \mathrm{min} / \mathrm{mg})$ in channel catfish from the MRB (Schmitt and others, 2002) than those from the CDRB. More data is needed to determine whether EROD activity was elevated or within the normal range in channel catfish from the CDRB.

\section{EROD in other species}

Hepatic EROD activity was also measured in flathead catfish, brown trout, and white sucker. Activity differed among fishes, and few studies have described basal activity in

Figure 12. Hepatic microsomal EROD activity $(\mathrm{pmol} / \mathrm{min} / \mathrm{mg})$ by station in female and male carp, bass (Micropterus sp.), and channel catfish from the Colorado River Basin in 2003. Shown for each group are points representing individual fish and the mean (red horizontal line), median (black horizontal line), interquartile range (box), and the 10th and 90th percentiles (whiskers). Stations are ordered from upstream to downstream and are grouped by sub-basin. See Table 2 for station descriptions. 
Table 17. Geometric mean, sample size ( $n)$, minimum (Min), and maximum (Max) of microsomal EROD activity ( $\mathrm{pmol} / \mathrm{mg} / \mathrm{min}$ protein) in fish collected in the Colorado River Basin in 2003. Censored values were represented by one half the LOD in the computation of geometric means. Fish in which gender was undetermined or no gonad was obtained are listed as NG. The maximum geometric station mean is shown in bold for each taxon. Stations are ordered upstream to downstream. --, not applicable.

\begin{tabular}{|c|c|c|c|c|c|c|c|c|c|c|c|c|}
\hline \multirow{2}{*}{ Taxon and station } & \multicolumn{4}{|c|}{ Female } & \multicolumn{4}{|c|}{ Male } & \multicolumn{4}{|c|}{ NG } \\
\hline & $n$ & Mean & Min & Max & $n$ & Mean & Min & Max & $n$ & Mean & Min & Max \\
\hline \multicolumn{13}{|l|}{ Carp } \\
\hline Lay, CO (311) & 0 & -- & -- & -- & 0 & -- & -- & -- & 1 & 0.9 & -- & -- \\
\hline Ouray NWR, UT (312) & 11 & 0.7 & 0.03 & 5.3 & 9 & 1.5 & 0.03 & 5.0 & 0 & -- & -- & -- \\
\hline San Rafael, UT (313) & 10 & 3.4 & 0.9 & 13.9 & 11 & 8.8 & 2.7 & 31.6 & 0 & -- & -- & -- \\
\hline Delta, CO (314) & 13 & 2.0 & 0.9 & 5.1 & 8 & 4.0 & 2.4 & 5.3 & 0 & -- & -- & -- \\
\hline Loma, CO (315) & 10 & 1.5 & 0.5 & 4.9 & 10 & 4.2 & 1.6 & 17.4 & 0 & -- & -- & -- \\
\hline Gold Bar Canyon, UT (316) & 10 & 1.0 & 0.2 & 8.1 & 10 & 3.8 & 1.2 & 10.2 & 0 & -- & -- & -- \\
\hline Hogback Diversion, NM (317) & 7 & 0.8 & 0.4 & 1.7 & 13 & 3.2 & 0.4 & 39.9 & 0 & -- & -- & -- \\
\hline South Cove, AZ (319) & 11 & 3.4 & 0.5 & 136.2 & 6 & 3.4 & 1.4 & 5.4 & 0 & -- & -- & -- \\
\hline Willow Beach, AZ (320) & 9 & 4.4 & 1.4 & 18.4 & 11 & 4.5 & 1.6 & 22.7 & 0 & -- & -- & -- \\
\hline Needles, CA (321) & 12 & 2.0 & 1.1 & 6.3 & 8 & 3.7 & 0.6 & 6.0 & 0 & -- & -- & -- \\
\hline Imperial Dam, AZ (322) & 12 & 1.0 & 0.4 & 1.8 & 8 & 1.2 & 0.2 & 7.4 & 0 & -- & -- & -- \\
\hline Hayden, AZ (323) & 6 & 1.3 & 0.9 & 3.2 & 13 & 2.0 & 0.3 & 6.9 & 0 & -- & -- & -- \\
\hline Phoenix, AZ (324) & 8 & 9.1 & 1.7 & 44.4 & 10 & 10.7 & 5.0 & 41.7 & 2 & 0.1 & 0.01 & 1.5 \\
\hline Arlington, AZ (325) & 13 & 1.9 & 0.1 & 12.9 & 7 & 2.1 & 0.1 & 15.8 & 0 & -- & -- & -- \\
\hline \multicolumn{13}{|l|}{ Bass } \\
\hline Lay, CO (311) & 9 & 7.0 & 3.8 & 11.6 & 10 & 23.4 & 14.5 & 30.1 & 1 & 7.8 & -- & -- \\
\hline Ouray NWR, UT (312) & 6 & 13.2 & 0.03 & 66.1 & 8 & 61.2 & 39.8 & 104.5 & 0 & -- & -- & -- \\
\hline Loma, CO (315) & 5 & 11.6 & 4.8 & 20.3 & 7 & 15.1 & 3.8 & 41.4 & 0 & -- & -- & -- \\
\hline Needles, CA (321) & 11 & 7.3 & 3.8 & 16.5 & 9 & 13.1 & 2.6 & 28.6 & 0 & -- & -- & -- \\
\hline Imperial Dam, AZ (322) & 10 & 4.5 & 1.4 & 12.5 & 10 & 3.5 & 1.2 & 9.8 & 0 & -- & -- & -- \\
\hline Hayden, AZ (323) & 4 & 2.5 & 1.4 & 10.1 & 5 & 6.3 & 2.6 & 14.7 & 0 & -- & -- & -- \\
\hline Phoenix, AZ (324) & 0 & -- & -- & -- & 2 & 4.4 & 2.8 & 6.7 & 0 & -- & -- & -- \\
\hline Arlington, AZ (325) & 11 & 9.0 & 4.2 & 27.6 & 9 & 9.4 & 2.2 & 27.8 & 0 & -- & -- & -- \\
\hline \multicolumn{13}{|l|}{ Channel catfish } \\
\hline Ouray NWR, UT (312) & 5 & 6.3 & 3.1 & 10.2 & 6 & 10.8 & 5.7 & 14.9 & 0 & -- & -- & -- \\
\hline San Rafael, UT (313) & 4 & 8.9 & 4.3 & 18.2 & 14 & 6.9 & 3.1 & 18.0 & 0 & -- & -- & -- \\
\hline Loma, CO (315) & 2 & 11.2 & 7.3 & 17.4 & 1 & 4.6 & -- & -- & 2 & 4.8 & 3.2 & 7.3 \\
\hline Gold Bar Canyon, UT (316) & 10 & 5.1 & 2.0 & 11.0 & 10 & 6.4 & 1.6 & 20.5 & 0 & -- & -- & -- \\
\hline Hogback Diversion, NM (317) & 11 & 7.5 & 3.8 & 17.3 & 8 & 6.8 & 4.0 & 13.2 & 1 & 5.7 & -- & -- \\
\hline Phoenix, AZ (324) & 13 & 5.3 & 1.4 & 14.1 & 3 & 3.7 & 1.8 & 6.4 & 0 & -- & -- & -- \\
\hline \multicolumn{13}{|l|}{ Flathead catfish } \\
\hline Hayden, AZ (323) & 3 & 5.0 & 3.6 & 6.4 & 7 & 5.3 & 3.0 & 8.5 & 1 & 4.6 & -- & -- \\
\hline \multicolumn{13}{|l|}{ Brown trout } \\
\hline Delta, CO (314) & 11 & 1.4 & 0.2 & 9.6 & 9 & 8.0 & 2.3 & 19.3 & 1 & 7.7 & -- & -- \\
\hline \multicolumn{13}{|l|}{ White sucker } \\
\hline Lay, CO (311) & 11 & 3.4 & 1.2 & 12.9 & 8 & 27.4 & 11.5 & 111.4 & 0 & -- & -- & -- \\
\hline
\end{tabular}


these species (Whyte and others, 2000). Those for which such comparisons can be made are summarized below.

White sucker were collected from Station 311, and mean EROD activity was greater in males $(27.4 \mathrm{pmol} / \mathrm{min} / \mathrm{mg})$ than in females (3.41 pmol/min/mg; table 17). Hepatic EROD activity was $5-15 \mathrm{pmol} / \mathrm{min} / \mathrm{mg}$ in white sucker from reference sites in previous studies (Couillard and Hodson, 1996; Schrank and others, 1997; Whyte and others, 2000), and gender differences were not significant in any of these studies. Mean EROD activity was $35.2 \mathrm{pmol} / \mathrm{min} / \mathrm{mg}$ in white sucker from a site contaminated by PCBs, PAHs, and heavy metals (Schrank and others, 1997). Mean EROD activity in brown trout was $1.38 \mathrm{pmol} / \mathrm{min} / \mathrm{mg}$ in females, $7.98 \mathrm{pmol} / \mathrm{min} / \mathrm{mg}$ in males, and $7.66 \mathrm{pmol} / \mathrm{min} / \mathrm{mg}$ in a juvenile from Station 314 (table 17). These activities were similar to basal activities reported in brown trout from previous studies (Whyte and others, 2000). Mean EROD activity in flathead catfish from Station 323 was $5.02 \mathrm{pmol} / \mathrm{min} / \mathrm{mg}$ in females, $5.25 \mathrm{pmol} / \mathrm{min} / \mathrm{mg}$ in males, and $4.54 \mathrm{pmol} / \mathrm{min} / \mathrm{mg}$ in a juvenile (table 17) and were similar to those measured in channel catfish. Other studies measuring EROD activity in flathead catfish were not found.

\section{Accumulative Contaminants, $\mathrm{H} 4 \mathrm{IIE}$, and EROD Activity: Summary}

Concentrations of most organochlorine residues and elemental contaminants measured in CDRB fish were low. Concentrations of $\mathrm{Se}$ and $\mathrm{Hg}$ exceeded toxicity thresholds in samples from multiple stations. Se naturally occurs in the Mancos shale of the Upper CDRB, and Se contamination has received much attention in the CDRB. Although the main source of Se is leaching in irrigation canals, Se is transported to the Lower CDR with the high silt and sediment load of the Upper CDR (Welsh and Maughan, 1994). Selenium concentrations were $>1.0 \mu \mathrm{g} / \mathrm{g}$ in at least one sample from all stations except Station 323, which could be harmful to piscivorous wildlife (Lemly, 1996, 2002). Probable Hg sources in the CDRB include historical mining areas and associated processes, coal-fired power plants, and naturally mineralized soils. Mercury concentrations were $>0.3 \mu \mathrm{g} / \mathrm{g}$ in channel catfish at Station 313 and may represent a threat to piscivorous birds (Barr, 1986). Mercury concentrations were $>0.1 \mu \mathrm{g} / \mathrm{g}$ in at least one sample from Stations 311, 312, 313, 315, 316, 317,321 , and 323 and may be hazardous to piscivorous mammals at these sites (Yeardley and others, 1998).

Organochlorine concentrations of banned pesticides in fish from the Lower GRB exceeded wildlife threshold criteria, which confirmed previous findings. Concentrations of $p, p^{\prime}-$ DDE in all samples from Station $325(>1.0 \mu \mathrm{g} / \mathrm{g})$ and channel catfish from Station $324(>0.5 \mu \mathrm{g} / \mathrm{g})$ may pose a risk to fish and wildlife (Blus, 1996; Jarvinen and Ankley, 1999). Little or no $p, p$ '-DDT was detected at these stations, indicating the continued weathering of residual DDT rather than the input of new material. However, relatively high concentrations of $o, p^{\prime}$-homologs were initially reported in samples from Sta- tions 324 and 325. After comparing sample chromatographic peaks with PBDE standards, we determined that several PBDE congeners were interfering with $o, p^{\prime}$-DDT and $p, p^{\prime}$-DDD in these samples. An additional cleanup step and GC-MS were needed to accurately quantify $o, p^{\prime}$ - and $p, p^{\prime}$-homologs in samples from Stations 324 and 325 only. The PBDE congeners were not quantified for this report. Similar to $p, p$ '-DDE, toxaphene concentrations were relatively high $(>0.4 \mu \mathrm{g} / \mathrm{g})$ in those same samples. The greatest concentrations of dieldrin and total chlordanes were also measured at Stations 324 and 325 as well as Stations 314, 315, and 316. Concentrations of these contaminants were less than the effects thresholds. Concentrations of unlisted or restricted use pesticides including pentachlorobenzene, pentachloroanisole, $\gamma-\mathrm{HCH}$, dacthal, endosulfan, and methoxychlor were also relatively high in the Lower GR although toxicity thresholds for most of these chemicals were unavailable. Previous CDRB studies have either not measured or reported these unlisted or restricted use pesticides in fish, and comparison of 2003 concentrations to other studies is difficult. Nevertheless, many of these current use organochlorine pesticides can cause reproductive and developmental effects in fish and wildlife (McDonald, 1991; Ortiz and others, 2003; Shukla and Pandey, 1986; USEPA, 2002; Versonnen and others, 2004) and should continued to be monitored in the CDRB.

Concentrations of total PCBs were also generally low throughout the CDRB. The exceptions were fish collected from Stations 320 and 324, where concentrations of PCBs were $>0.5 \mu \mathrm{g} / \mathrm{g}$. Both of these stations were located downstream of major metropolitan areas. TCDD-EQs concentrations $>4 \mathrm{pg} / \mathrm{g}$ were measured in carp and channel catfish from Station 324, which in conjunction with the greater PCB concentrations at this station indicated that the dioxin-like activity in fish from that site was likely due to PCBs. Concentrations of TCDD-EQs were $>2 \mathrm{pg} / \mathrm{g}$ in channel catfish from Station 316 and carp from Station 320. Hepatic EROD activity was similar among stations, with a few exceptions. In carp, the greatest mean EROD activity was in fish from Station 324, which correlates with the elevated TCDD-EQ and PCB concentrations in these samples. In bass, mean EROD activities were greatest at Station 312; TCDD-EQs and PCB concentrations were low in these samples, which indicated that bass at this site were exposed to some other type of AhR agonist, such as a PAH. Large bituminous coal beds in northeastern Utah could be a potential PAH source in this area and may be contributing to the elevated EROD activities in fish. 
Table 18. Number and location of external lesions identified on fish collected in the Colorado River Basin in 2003. Body, eyes, opercles, and fins of each fish were examined for the presence of lesions, and the proportion of fish with lesions was calculated. Stations are listed upstream to downstream.

\begin{tabular}{|c|c|c|c|c|c|c|c|}
\hline \multirow[b]{2}{*}{ Station and species } & \multirow[b]{2}{*}{$n$} & \multicolumn{4}{|c|}{ Lesion location } & \multirow[b]{2}{*}{$\begin{array}{c}\text { Total no. } \\
\text { w/lesions }\end{array}$} & \multirow[b]{2}{*}{ Proportion } \\
\hline & & Body & Eyes & Opercles & Fins & & \\
\hline \multicolumn{8}{|l|}{ Lay, CO (311) } \\
\hline Smallmouth bass & 20 & 0 & 0 & 1 & 0 & 1 & 0.05 \\
\hline White sucker & 19 & 2 & 0 & 0 & 7 & 7 & 0.37 \\
\hline Carp & 1 & 0 & 0 & 0 & 0 & 0 & 0.00 \\
\hline \multicolumn{8}{|l|}{ Ouray NWR, UT (312) } \\
\hline Carp & 20 & 8 & 1 & 1 & 5 & 14 & 0.70 \\
\hline Channel catfish & 11 & 1 & 0 & 0 & 2 & 3 & 0.27 \\
\hline Smallmouth bass & 14 & 2 & 1 & 0 & 1 & 3 & 0.21 \\
\hline \multicolumn{8}{|l|}{ San Rafael, UT (313) } \\
\hline Carp & 21 & 2 & 1 & 0 & 5 & 7 & 0.33 \\
\hline Channel catfish & 18 & 7 & 0 & 1 & 7 & 10 & 0.56 \\
\hline \multicolumn{8}{|l|}{ Delta, CO (314) } \\
\hline Brown trout & 21 & 0 & 1 & 0 & 15 & 16 & 0.76 \\
\hline Carp & 21 & 6 & 3 & 2 & 3 & 9 & 0.43 \\
\hline \multicolumn{8}{|l|}{ Loma, CO (315) } \\
\hline Carp & 20 & 2 & 1 & 1 & 5 & 8 & 0.40 \\
\hline Channel catfish & 5 & 3 & 2 & 0 & 3 & 4 & 0.80 \\
\hline Largemouth bass & 12 & 4 & 2 & 1 & 7 & 9 & 0.75 \\
\hline \multicolumn{8}{|l|}{ Gold Bar Canyon, UT (316) } \\
\hline Carp & 20 & 2 & 0 & 0 & 1 & 3 & 0.15 \\
\hline Channel catfish & 20 & 5 & 1 & 0 & 5 & 8 & 0.40 \\
\hline \multicolumn{8}{|l|}{ Hogback Diversion, NM (317) } \\
\hline Carp & 20 & 0 & 0 & 1 & 3 & 4 & 0.20 \\
\hline Channel catfish & 20 & 6 & 1 & 0 & 12 & 12 & 0.60 \\
\hline \multicolumn{8}{|l|}{ South Cove, AZ (319) } \\
\hline Carp & 17 & 2 & 0 & 1 & 0 & 3 & 0.18 \\
\hline \multicolumn{8}{|l|}{ Willow Beach, AZ (320) } \\
\hline Carp & 20 & 2 & 4 & 0 & 6 & 9 & 0.45 \\
\hline \multicolumn{8}{|l|}{ Needles, CA (321) } \\
\hline Carp & 20 & 3 & 0 & 2 & 2 & 5 & 0.25 \\
\hline Largemouth bass & 20 & 6 & 0 & 3 & 0 & 9 & 0.45 \\
\hline \multicolumn{8}{|l|}{ Imperial Dam, AZ (322) } \\
\hline Carp & 20 & 1 & 0 & 1 & 3 & 5 & 0.25 \\
\hline Largemouth bass & 20 & 0 & 2 & 2 & 0 & 4 & 0.20 \\
\hline \multicolumn{8}{|l|}{ Hayden, AZ (323) } \\
\hline Carp & 20 & 0 & 0 & 1 & 4 & 4 & 0.20 \\
\hline Flathead catfish & 11 & 1 & 0 & 0 & 0 & 1 & 0.09 \\
\hline Largemouth bass & 9 & 0 & 0 & 0 & 1 & 1 & 0.11 \\
\hline \multicolumn{8}{|l|}{ Phoenix, AZ (324) } \\
\hline Carp & 20 & 2 & 0 & 1 & 5 & 7 & 0.35 \\
\hline Channel catfish & 15 & 1 & 0 & 0 & 6 & 7 & 0.47 \\
\hline Largemouth bass & 2 & 0 & 0 & 0 & 0 & 0 & 0.00 \\
\hline Arlington, AZ (325) & & & & & & & \\
\hline Carp & 20 & 2 & 0 & 1 & 8 & 9 & 0.45 \\
\hline Largemouth bass & 20 & 2 & 0 & 1 & 6 & 7 & 0.35 \\
\hline Basin Totals & & & & & & & \\
\hline All & 517 & 72 & 20 & 21 & 122 & 189 & 0.37 \\
\hline Carp & 260 & 32 & 10 & 12 & 50 & 87 & 0.34 \\
\hline Bass & 117 & 14 & 5 & 8 & 15 & 34 & 0.58 \\
\hline Channel catfish & 89 & 23 & 4 & 1 & 35 & 44 & 0.49 \\
\hline White sucker & 19 & 2 & 0 & 0 & 7 & 7 & 0.37 \\
\hline Brown trout & 21 & 0 & 1 & 0 & 15 & 16 & 0.76 \\
\hline Flathead catfish & 11 & 1 & 0 & 0 & 0 & 1 & 0.09 \\
\hline
\end{tabular}




\section{Fish Health Indicators}

\section{Organism-Level Indicators}

\section{External Gross Lesions}

External gross lesions (abnormalities) were identified on $37 \%$ of CDRB fish during the fish health examination in the field. These lesions were categorized by location including lesions on the body surface, eyes, opercles, and fins. More lesions were generally found on Upper CDRB fish than Lower CDRB fish (table 18). High proportions of lesions $(\geq 70 \%)$ occurred in carp from Station 312, brown trout from Station 314, and bass and channel catfish from Station 315.

Overall, lesions were identified on $34 \%$ of carp. External lesions were identified on $<50 \%$ of carp from most sites (table 18). Lesions on carp were primarily attributed to frayed fins and nodules on the body surface and fins. Eye lesions on carp from Station $314(n=3)$ were identified as black spots or exophthalmic, and those from Station $320(n=4)$ were opaque. External lesions were found on $58 \%$ of bass, and the greatest proportion $(75 \%)$ was found on bass from Station 315 (table 18). Most bass lesions were described as nodules on the fins or mouth and frayed fins. External lesions were found on $49 \%$ of channel catfish, and the greatest lesion occurrence (>50\%) was observed in fish from Stations 313, 315, and 317 (table 18). Most external lesions in channel catfish were parasites on the body or fins. In general, the proportion of CDRB fish with external lesions was lower than the proportion identified in previous LRMN investigations (Blazer and others, 2002; Hinck and others, 2004a; Schmitt and others, 2004). Statistical comparisons among basins are not part of this report.

External lesions were collected during field necropsy for histopathological examination. Most nodules on the body surface and fins were inflammatory responses from parasitic infestations. Two raised fin lesions on carp from Station 320 were diagnosed as fibrotic lesions with inflammation and increased numbers of melanocytes, and a hematoma was identified on the opercle of a carp from Station 324. A fibroma and papilloma were observed on catfish from Station 313, and a papilloma was observed on a bass and a carp from Station 321.

\section{Health Assessment Index}

The health assessment index (HAI) is a systematic method to identify external and internal lesions for each fish during field necropsy. A higher HAI score indicates that a greater number of lesions were identified on the fish. The HAI may vary depending on gender and gonadal stage (Schmitt, 2002). The gender and gonadal stage did not influence HAI in carp, bass, or channel catfish (Appendix 7). Therefore, gender and gonadal stage data were combined for data analysis.
Most HAI scores in carp (91\%) ranged from 0 to 70 , indicating that most fish had zero to three lesions (table 19). Mean HAI scores were $<40$ in carp in the Upper CDRB and the GRB and $>47$ in carp from the Lower CDR (table 19; fig. 13). Liver discoloration, granular spleen and kidney, and pale gills accounted for most elevated HAI scores at Stations 319, 320, 321, and 322 (fig. 13). These data are similar to HAI scores in carp from the MRB (Blazer and others, 2002), RGB (Schmitt and others, 2004), and CRB (Hinck and others, 2004a).

HAI scores in bass were greater than those in carp. Most HAI scores in bass (87\%) ranged from 0 to 100 (table 19). Mean HAI scores ranged from 50 to 103 from all stations except Stations 311 and 312, where all smallmouth bass were collected (fig. 13). HAI scores in bass from Stations 315 , 321 , and 322 were greater $(>90)$ than those from other stations (table 19). Liver discoloration, granular liver, kidney, and spleen, and body surface lesions elevated HAI scores in fish from Station 315, 321, and 322. In general, HAI scores in bass from these three stations were greater than those measured in bass from the MRB (Blazer and others, 2002), RGB (Schmitt and others, 2004), and CRB (Hinck and others, 2004a).

Most HAI scores in channel catfish $(85 \%)$ ranged from 0 to 70 (table 19), and mean HAI scores were $<43$ except in fish from Stations 315 (70; $n=5)$ and 317 (81; fig. 13). Elevated HAI scores in fish from Stations 315 and 317 were attributed to head and eye lesions, frayed and eroded fins, liver discoloration, and granular spleen (fig. 13). HAI scores in channel catfish were 0-30 in the MRB and 10-70 in the RGB (BESTLRMN program, unpublished data).

\section{Condition factor and Organosomatic Indices}

These indices were calculated from body and organ weights in individual fish and considered general indicators of the overall fish health. Alterations of these indices may be indicative of effects resulting from exposure to contaminants (Schmitt and Dethloff, 2000). These indices can vary among species, gender, and gonadal stage. ANOVA models containing the factors station, gender, and gonadal stage were tested to determine if these factors influenced condition factor, HSI, and SSI in carp, bass, and channel catfish (Appendix 7).

\section{Condition factor and Organosomatic Indices in Carp}

Condition factor values did not differ among stations $\left(F_{12,205}=1.22, P>0.05\right)$ or between genders $\left(F_{1,205}=0.01, P\right.$ $>0.05)$ in carp. The basin-wide mean $\mathrm{CF}$ value was 1.17 in carp. Means were similar among stations and ranged from 1.00 at Station 314 to 1.24 at Station 317 (table 20). The CF value was 1.87 in one carp from Station 311. Relatively high $\mathrm{CF}$ values $(>1.60)$ were calculated for carp from Stations 311 and 320, and low CF values $(<0.80)$ characterized multiple carp from Stations 314, 315, and 321 (fig. 14). Mean CF values in carp were 1.1-1.5 in the MRB (Blazer and others, 2002), 1.2-1.5 in the RGB (Schmitt and others, 2004), and 


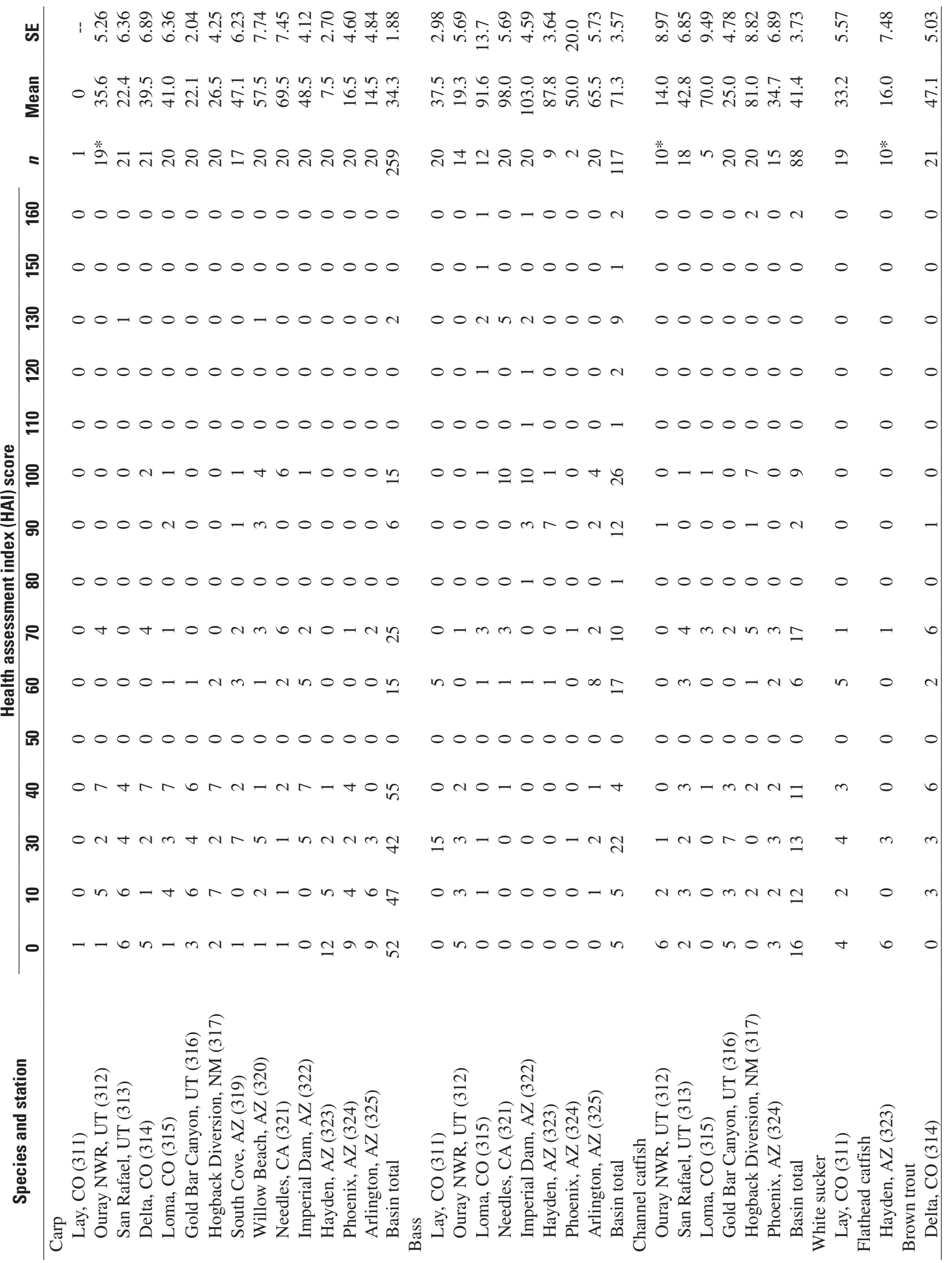




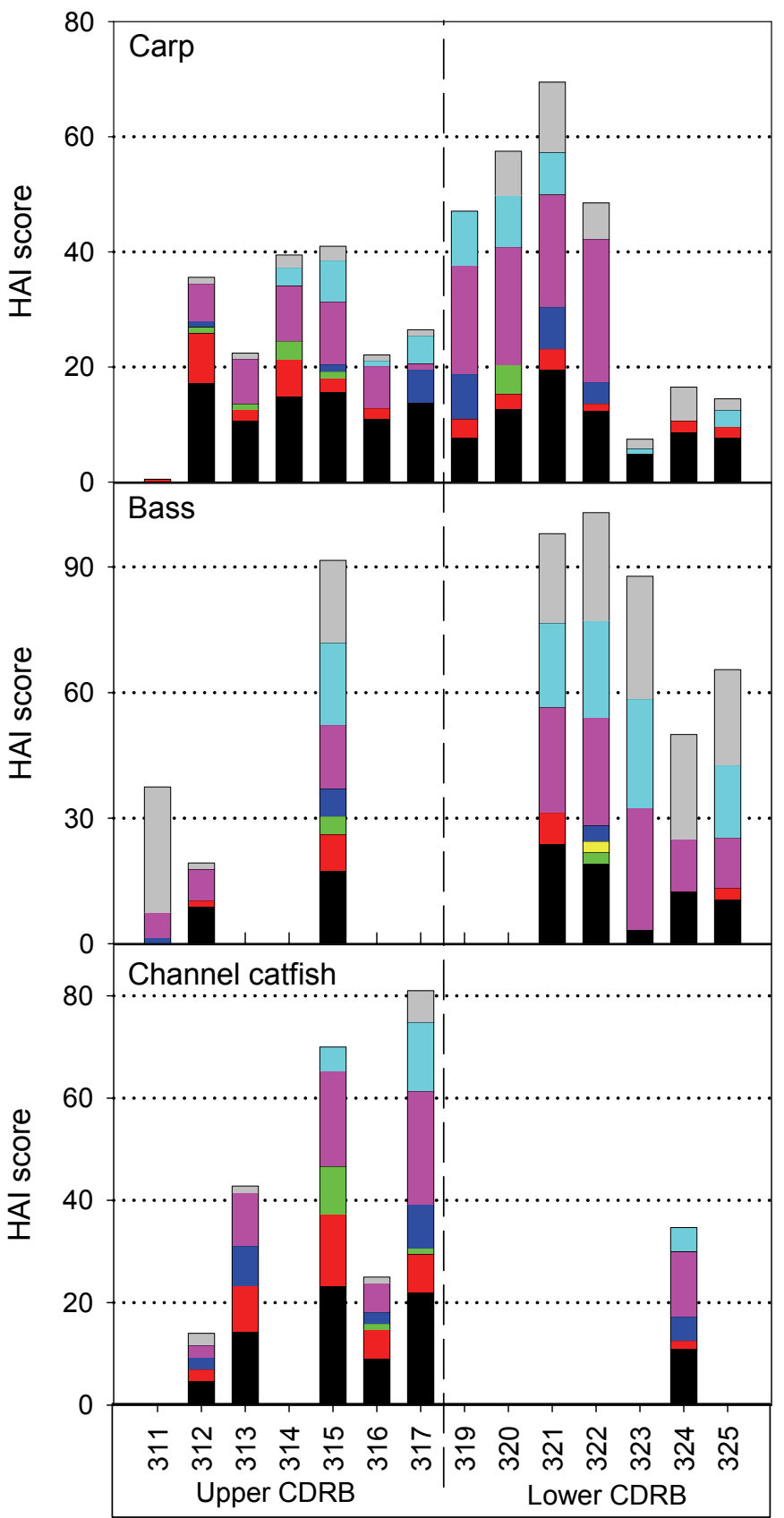

Station

\begin{tabular}{|ll|}
\hline Fin & Gill \\
Body surface & Liver \\
$\square$ Eye & $\square$ Spleen \\
$\square$ Opercle & $\square$ Kidney \\
\hline
\end{tabular}

Figure 13. Mean HAl scores by lesion location in carp, bass, and channel catfish from the Colorado River Basin in 2003. Stations are ordered from upstream to downstream and are grouped by sub-basin. See Table 2 for station descriptions.
1.2-1.9 in the CRB (Hinck and others, 2004a), and CF values $<0.80$ were rare in carp from these studies. Mean $\mathrm{CF}$ values were approximately 1-2 in carp from the Las Vegas Bay of Lake Mead (Patiño and others, 2003b). The CF values in CDRB carp were generally less than those reported for carp (1.2 to $>2.0)$ in a national survey (Carlander, 1969).

Relative spleen sizes in carp differed among stations $\left(F_{12}\right.$, $\left.{ }_{212}=2.96, P<0.01\right)$ and between genders $\left(F_{1,212}=14.86, P<\right.$ 0.01 ); therefore, males and females were analyzed separately. The basin-wide mean SSI value in female carp was $0.21 \%$ (table 21). Station means ranged from $0.16 \%$ at Stations 324 and 325 to $0.30 \%$ at Station 317 . Values were $\geq 0.30 \%$ in fish from Stations 312, 314, 315, 316, 317, and 320 and $\leq 0.10 \%$ in fish from Stations 319 and 324 (fig. 14). Mean SSI values in female carp from the CDRB were similar to those from the MRB (0.09-0.87\%; Blazer and others, 2002), the RGB (0.10$0.30 \%$; Schmitt and others, 2004), and the CRB (0.15-0.39\%; Hinck and others, 2004a).

The SSI was generally greater in male carp than female carp. The basin-wide mean SSI value in male carp was $0.27 \%$ (table 21). Station means ranged from $0.15 \%$ at Station 324 to $0.46 \%$ at Station 315. Individual SSI values were $>0.50 \%$ in fish from Stations 312, 315, and 320 (fig. 14). The SSI value was $1.74 \%$ in one fish from Station 315, but the spleen tissue was histologically described as normal. This is the greatest SSI value calculated for male carp from any LRMN investigation, but SSI values $>2.0 \%$ were measured in several female carp from the MRB (Blazer and others, 2002). Mean SSI values in male carp from the CDRB were similar to those from the MRB (0.04-0.50\%; Blazer and others, 2002), the RGB (0.10-0.40\%; Schmitt and others, 2004), and the CRB (0.22$0.44 \%$; Hinck and others, 2004a).

\section{Condition factor and Organosomatic Indices in Bass}

Condition factor values in bass did not differ among stations $\left(F_{5,92}=1.47, P>0.05\right)$ or between genders $\left(F_{1,92}=1.43\right.$, $P>0.05$ ). The basin-wide mean $\mathrm{CF}$ value in bass was 1.34 , and station means ranged from 0.99 at Stations 315 and 321 to 1.65 at Station 311 (table 20). Values $>1.5$ were calculated for fish from all stations except Station 321, and values $<1.0$ were calculated for fish from Stations 315 and 321 only (fig. 15). As previously mentioned, $\mathrm{CF}$ values were also low in carp from Stations 315 and 321. Multiple studies have reported that $\mathrm{CF}$ values of 1.0-2.0 are typical in healthy largemouth and smallmouth bass (Blazer and others, 2002; Carlander, 1977; Hinck and others, 2004a; Schmitt and others, 2004; Sepúlveda and others, 2001). Some internal lesions in bass at Station 321 may be associated with the low CF values. A number of bass exhibited fatty infiltration and degeneration of hepatocytes, large MAs, and a very high helminth parasite load in the liver, kidney, and spleen. Some bass also had myxosporidian parasites in the kidney.

HSI values in bass differed among stations $\left(F_{7,101}=\right.$ $18.83, P<0.01)$ but not between genders $\left(F_{1,101}=0.50, P>\right.$ 0.05 ). The basin-wide mean HSI value in bass was $1.15 \%$, 
Table 20. Arithmetic mean of condition factor (CF) by species and station in carp, bass, and channel catfish collected in the Colorado River Basin in 2003. Female and male fish were separated when analysis-of-variance modeling determined that gender was a significant factor. Number of samples $(n)$, minimum (Min), maximum (Max), and standard error (SE) are also given. Stations are ordered upstream to downstream. The maximum station mean for each taxon is shown in bold. --, not applicable.

\begin{tabular}{|c|c|c|c|c|c|}
\hline \multirow{2}{*}{ Taxon and station } & \multicolumn{5}{|c|}{ Condition factor (CF) } \\
\hline & $n$ & Mean & Min & Max & SE \\
\hline \multicolumn{6}{|l|}{ Carp } \\
\hline Basin Total & 258 & 1.17 & 0.60 & 1.87 & 0.01 \\
\hline Lay, CO (311) & 1 & 1.87 & -- & -- & -- \\
\hline Ouray NWR, UT (312) & 20 & 1.21 & 1.02 & 1.34 & 0.02 \\
\hline San Rafael, UT (313) & 21 & 1.15 & 0.97 & 1.44 & 0.03 \\
\hline Delta, CO (314) & 21 & 1.00 & 0.60 & 1.49 & 0.05 \\
\hline Loma, CO (315) & 20 & 1.19 & 0.72 & 1.50 & 0.06 \\
\hline Gold Bar Canyon, UT (316) & 20 & 1.08 & 0.96 & 1.23 & 0.02 \\
\hline Hogback Diversion, NM (317) & 19 & 1.24 & 0.94 & 1.54 & 0.03 \\
\hline South Cove, AZ (319) & 17 & 1.18 & 1.06 & 1.33 & 0.02 \\
\hline Willow Beach, AZ (320) & 20 & 1.20 & 0.63 & 1.79 & 0.05 \\
\hline Needles, CA (321) & 20 & 1.19 & 0.71 & 1.54 & 0.05 \\
\hline Imperial Dam, AZ (322) & 20 & 1.20 & 1.00 & 1.31 & 0.02 \\
\hline Hayden, AZ (323) & 20 & 1.22 & 1.10 & 1.38 & 0.02 \\
\hline Phoenix, AZ (324) & 19 & 1.17 & 0.98 & 1.38 & 0.02 \\
\hline Arlington, AZ (325) & 20 & 1.19 & 1.01 & 1.45 & 0.02 \\
\hline \multicolumn{6}{|l|}{ Bass } \\
\hline Basin Total & 117 & 1.34 & 0.52 & 2.07 & 0.03 \\
\hline Lay, CO (311) & 20 & 1.65 & 1.26 & 2.07 & 0.04 \\
\hline Ouray NWR, UT (312) & 14 & 1.49 & 1.33 & 1.71 & 0.03 \\
\hline Loma, CO (315) & 12 & 0.99 & 0.52 & 1.77 & 0.13 \\
\hline Needles, CA (321) & 20 & 0.99 & 0.55 & 1.36 & 0.07 \\
\hline Imperial Dam, AZ (322) & 20 & 1.27 & 0.69 & 1.54 & 0.04 \\
\hline Hayden, AZ (323) & 9 & 1.35 & 1.26 & 1.54 & 0.03 \\
\hline Phoenix, AZ (324) & 2 & 1.60 & 1.42 & 1.77 & 0.18 \\
\hline Arlington, AZ (325) & 20 & 1.51 & 1.31 & 1.71 & 0.03 \\
\hline \multicolumn{6}{|l|}{ Female Channel catfish } \\
\hline Basin Total & 44 & 0.79 & 0.45 & 1.10 & 0.02 \\
\hline Ouray NWR, UT (312) & 5 & 0.70 & 0.59 & 0.85 & 0.04 \\
\hline San Rafael, UT (313) & 4 & 0.65 & 0.45 & 0.75 & 0.07 \\
\hline Loma, CO (315) & 2 & 0.65 & 0.48 & 0.81 & 0.17 \\
\hline Gold Bar Canyon, UT (316) & 10 & 0.67 & 0.56 & 0.85 & 0.03 \\
\hline Hogback Diversion, NM (317) & 11 & 0.89 & 0.75 & 1.05 & 0.03 \\
\hline Phoenix, AZ (324) & 12 & 0.92 & 0.76 & 1.1 & 0.03 \\
\hline \multicolumn{6}{|l|}{ Male Channel catfish } \\
\hline Basin Total & 41 & 0.79 & 0.59 & 1.09 & 0.02 \\
\hline Ouray NWR, UT (312) & 6 & 0.70 & 0.59 & 0.78 & 0.03 \\
\hline San Rafael, UT (313) & 14 & 0.81 & 0.68 & 1.09 & 0.03 \\
\hline Loma, CO (315) & 1 & 1.06 & -- & -- & -- \\
\hline Gold Bar Canyon, UT (316) & 10 & 0.68 & 0.59 & 0.82 & 0.02 \\
\hline Hogback Diversion, NM (317) & 8 & 0.89 & 0.81 & 0.97 & 0.02 \\
\hline Phoenix, AZ (324) & 2 & 0.97 & 0.95 & 0.99 & 0.02 \\
\hline
\end{tabular}




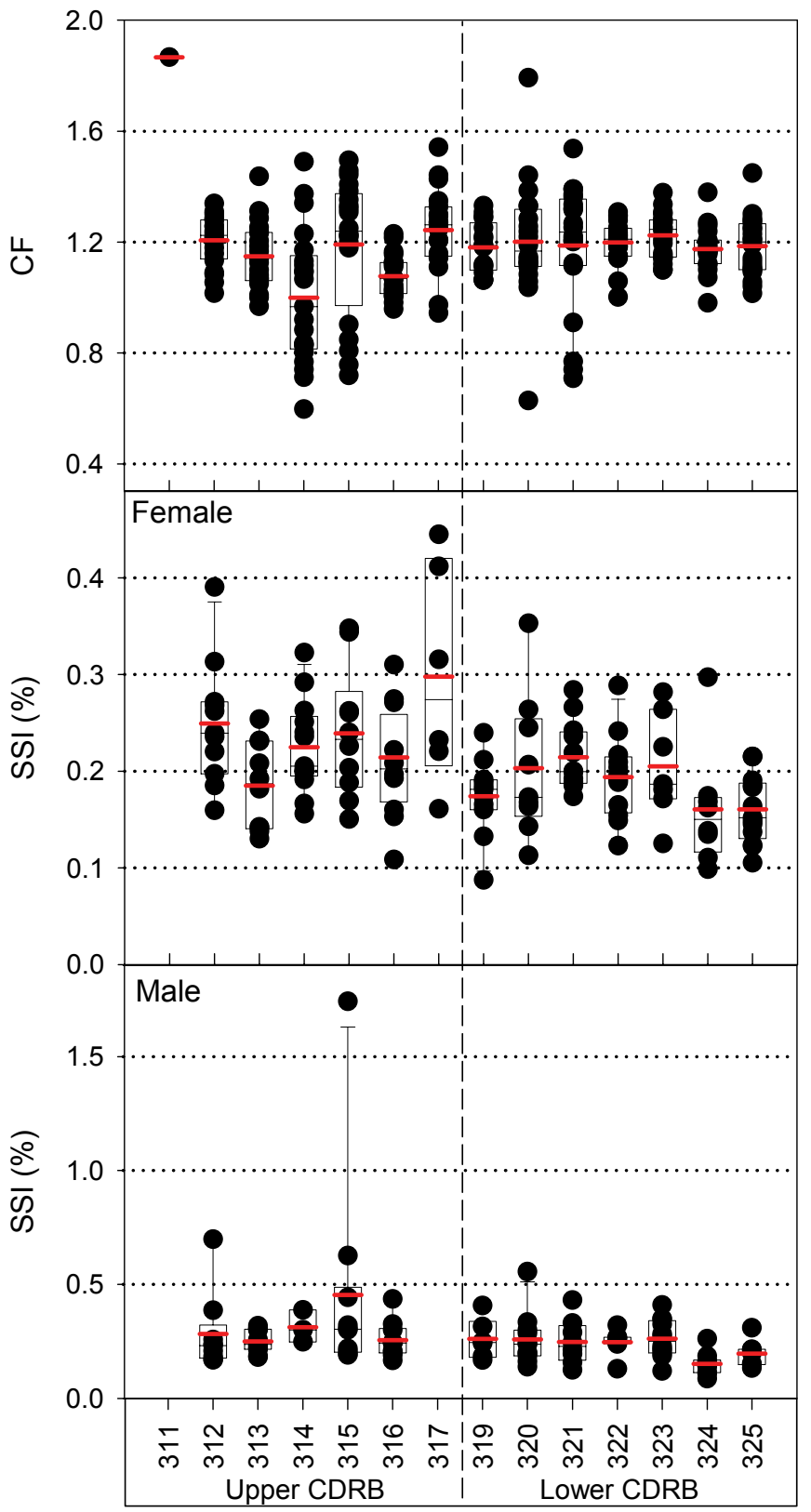

Station

Figure 14. Fish health indicators by station in female and male carp from the Colorado River Basin in 2003. Indicators include condition factor (CF) and splenosomatic index (SSI). Females and males were plotted separately when analysis-of-variance modeling determined gender was a significant factor. Shown for each group are points representing individual fish and the mean (red horizontal line), median (black horizontal line), interquartile range (box), and the 10th and 90th percentiles (whiskers). Stations are ordered from upstream to downstream and are grouped by sub-basin. See Table 2 for station descriptions. and station means ranged from $0.66 \%$ at Station 312 to $1.73 \%$ at Station 311 (table 22). Hepatosomatic index values were $>2.0 \%$ in fish from Station 311 only. Relatively low HSI values $(<1.0 \%)$ were found in fish from all stations except Station 315, and station means were $<1.0 \%$ at Stations 312, 321, and 322 (fig. 15). At Station 312, liver tissue was described as normal during both the field necropsy and histopathological examination. The livers of bass from Stations 321 and 322 were identified as abnormal (that is, tan and nodular) during field examination, but most livers from other stations were normal. The pale or tan appearance was likely due to the fatty infiltration or vacuolization of the hepatocytes, and the nodular appearance may be from helminth parasites and associated inflammation. Mean HSI values in bass were 0.6-2.0\% in the MRB (Blazer and others, 2002), 0.7-1.0\% in the RGB (Schmitt and others, 2004), and 0.9-2.3\% in the CRB (Hinck and others, 2004a). Gingerich (1982) determined a comparative range for normal liver weight in fish to be $1-3 \%$ of the total body weight. Liver weights in many CDRB bass were below this benchmark but were similar to those reported in other LRMN studies.

SSI values in bass differed among stations $\left(F_{7,101}=3.56\right.$, $P<0.01)$ but not between genders $\left(F_{1,101}=0.08, P>0.05\right)$. The basin-wide mean SSI value in bass was $0.11 \%$, and station means ranged from $0.03 \%$ at Station $324(n=2)$ to $0.16 \%$ at Station 315 (table 21). Individual SSI values were $>0.2 \%$ in fish from Stations 311, 315, and 321. SSI values were $\leq 0.03 \%$ in fish from Stations 311, 315, and 324 (fig. 15), and splenic tissues in these fish appeared histologically normal except for the presence of parasites. Mean SSI values in bass were 0.09$0.24 \%$ in the MRB (Blazer and others, 2002), 0.1-0.2\% in the RGB (Schmitt and others, 2004), and 0.11-0.25\% in the CRB (Hinck and others, 2004a). The SSI values in CDRB bass were generally lower than those measured in previous studies.

\section{Condition factor and Organosomatic Indices in Channel catfish}

Condition factor values in channel catfish differed among stations $\left(F_{5,62}=7.45, P<0.01\right)$, gonadal stages $\left(F_{1,62}=12.25\right.$, $P<0.01)$, and between genders $\left(F_{1,62}=6.41, P<0.05\right)$; therefore, females and males were analyzed separately. The basin-wide mean CF value in female channel catfish was 0.79 , and station means ranged from 0.65 at Stations 313 and 315 to 0.92 at Station 324 (table 20). The CF values were 0.60-1.00 in most females $(80 \%)$ and were generally greatest $(>0.80)$ in fish from Stations 317 and 324 (fig. 16). CF values were low $(<0.60)$ in females from Stations 312, 313, 315, and 316, and most of these fish were stage 1 . The basin-wide mean $\mathrm{CF}$ value in male channel catfish was 0.79 (table 20). Station means ranged from 0.68 at Station 316 to 1.06 at Station 315 $(n=1)$, and most CF values (95\%) were $<1.0$ (fig. 16). Similar to female channel catfish, CF values were low $(<0.60)$ in males from Stations 312, 313, 315, and 316. These fish were in stages 0-4. The CF values in CDRB channel catfish were 
Table 21. Arithmetic mean of splenosomatic index (SSI; \%) by species and station in carp, bass, and channel catfish collected in the Colorado River Basin in 2003. Female and male fish were separated when analysis-of-variance modeling determined gender was a significant factor. Number of samples $(n)$, minimum (Min), maximum (Max), and standard error (SE) are also given. Stations are ordered upstream to downstream. The maximum station mean for each taxon is shown in bold. --, not applicable.

\begin{tabular}{|c|c|c|c|c|c|}
\hline \multirow{2}{*}{ Taxon and station } & \multicolumn{5}{|c|}{ Splenosomatic index (SSI) } \\
\hline & $n$ & Mean & Min & Max & SE \\
\hline \multicolumn{6}{|l|}{ Carp } \\
\hline \multicolumn{6}{|l|}{ Female } \\
\hline Basin Total & 132 & 0.21 & 0.09 & 0.45 & 0.01 \\
\hline Ouray NWR, UT (312) & 11 & 0.25 & 0.16 & 0.39 & 0.02 \\
\hline San Rafael, UT (313) & 10 & 0.18 & 0.13 & 0.25 & 0.01 \\
\hline Delta, CO (314) & 13 & 0.23 & 0.16 & 0.32 & 0.01 \\
\hline Loma, CO (315) & 10 & 0.24 & 0.15 & 0.35 & 0.02 \\
\hline Gold Bar Canyon, UT (316) & 10 & 0.21 & 0.11 & 0.31 & 0.02 \\
\hline Hogback Diversion, UT (317) & 6 & 0.30 & 0.16 & 0.45 & 0.05 \\
\hline South Cove, AZ (319) & 11 & 0.17 & 0.09 & 0.24 & 0.01 \\
\hline Willow Beach, AZ (320) & 9 & 0.20 & 0.11 & 0.35 & 0.03 \\
\hline Needles, CA (321) & 12 & 0.22 & 0.17 & 0.28 & 0.01 \\
\hline Imperial Dam, AZ (322) & 12 & 0.19 & 0.12 & 0.29 & 0.01 \\
\hline Hayden, AZ (323) & 7 & 0.21 & 0.13 & 0.28 & 0.02 \\
\hline Phoenix, AZ (324) & 8 & 0.16 & 0.10 & 0.30 & 0.02 \\
\hline Arlington, AZ (325) & 13 & 0.16 & 0.11 & 0.22 & 0.01 \\
\hline \multicolumn{6}{|l|}{ Male } \\
\hline Basin Total & 105 & 0.27 & 0.09 & 1.74 & 0.02 \\
\hline Ouray NWR, UT (312) & 9 & 0.28 & 0.17 & 0.70 & 0.06 \\
\hline San Rafael, UT (313) & 11 & 0.25 & 0.18 & 0.32 & 0.01 \\
\hline Delta, CO (314) & 3 & 0.31 & 0.25 & 0.39 & 0.04 \\
\hline Loma, CO (315) & 10 & 0.46 & 0.19 & 1.74 & 0.15 \\
\hline Gold Bar Canyon, UT (316) & 10 & 0.26 & 0.17 & 0.44 & 0.03 \\
\hline Hogback Diversion, UT (317) & 0 & -- & -- & -- & -- \\
\hline South Cove, AZ (319) & 6 & 0.26 & 0.17 & 0.41 & 0.04 \\
\hline Willow Beach, AZ (320) & 11 & 0.26 & 0.14 & 0.56 & 0.04 \\
\hline Needles, CA (321) & 8 & 0.25 & 0.13 & 0.43 & 0.03 \\
\hline Imperial Dam, AZ (322) & 8 & 0.25 & 0.13 & 0.32 & 0.02 \\
\hline Hayden, AZ (323) & 12 & 0.26 & 0.12 & 0.41 & 0.02 \\
\hline Phoenix, AZ (324) & 10 & 0.15 & 0.09 & 0.26 & 0.01 \\
\hline Arlington, AZ (325) & 7 & 0.20 & 0.13 & 0.31 & 0.02 \\
\hline \multicolumn{6}{|l|}{ Bass } \\
\hline Basin Total & 117 & 0.11 & 0.02 & 0.47 & 0.01 \\
\hline Lay, CO (311) & 20 & 0.14 & 0.03 & 0.39 & 0.02 \\
\hline Ouray NWR, UT (312) & 14 & 0.07 & 0.05 & 0.12 & 0.01 \\
\hline Loma, CO (315) & 12 & 0.16 & 0.02 & 0.47 & 0.04 \\
\hline Needles, CA (321) & 20 & 0.14 & 0.05 & 0.28 & 0.02 \\
\hline Imperial Dam, AZ (322) & 20 & 0.09 & 0.04 & 0.14 & 0.01 \\
\hline Hayden, AZ (323) & 9 & 0.08 & 0.05 & 0.11 & 0.01 \\
\hline Phoenix, AZ (324) & 2 & 0.03 & 0.02 & 0.03 & 0.01 \\
\hline Arlington, AZ (325) & 20 & 0.09 & 0.05 & 0.20 & 0.01 \\
\hline \multicolumn{6}{|l|}{ Channel Catfish } \\
\hline Basin Total & 88 & 0.15 & 0.05 & 0.51 & 0.01 \\
\hline Ouray NWR, UT (312) & 11 & 0.14 & 0.07 & 0.20 & 0.01 \\
\hline San Rafael, UT (313) & 18 & 0.16 & 0.10 & 0.25 & 0.01 \\
\hline Loma, CO (315) & 5 & 0.20 & 0.10 & 0.51 & 0.08 \\
\hline Gold Bar Canyon, UT (316) & 20 & 0.14 & 0.08 & 0.25 & 0.01 \\
\hline Hogback Diversion, UT (317) & 20 & 0.19 & 0.07 & 0.45 & 0.02 \\
\hline Phoenix, AZ (324) & 14 & 0.08 & 0.05 & 0.11 & 0.01 \\
\hline
\end{tabular}




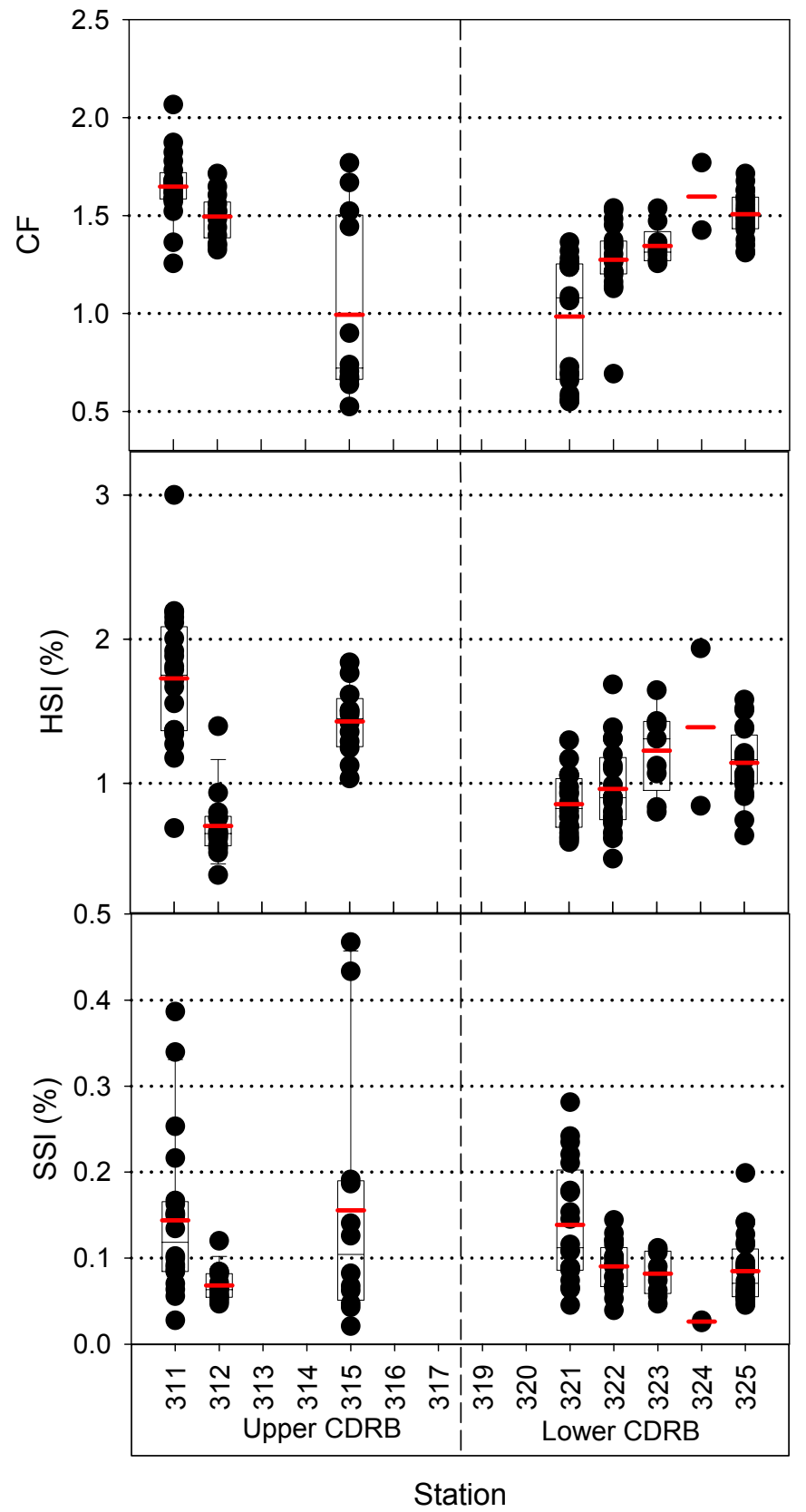

Figure 15. Fish health indicators by station in female and male bass (Micropterus sp.) from the Colorado River Basin in 2003. Indicators include condition factor (CF), hepatosomatic index (HSI), and splenosomatic index (SSI). Shown for each group are points representing individual fish and the mean (red horizontal line), median (black horizontal line), interquartile range (box), and the 10th and 90th percentiles (whiskers). Stations are ordered from upstream to downstream and are grouped by sub-basin. See Table 2 for station descriptions. similar to those reported in catfish from the MRB (0.9-1.1) and RGB (0.7-1.8; BEST-LRMN program, unpublished data).

HSI values in channel catfish differed among stations $\left(F_{5}\right.$, $\left.{ }_{73}=2.69, P<0.05\right)$ but not between genders $\left(F_{1,73}=0.20, P>\right.$ $0.05)$. The basin-wide mean HSI value was $1.45 \%$ in channel catfish, and station means ranged from $1.31 \%$ at Station 316 to $1.73 \%$ at Station 313 (table 22). Individual HSI values were $>2.0 \%$ in fish from Stations 312, 313, and 317 and $<1.0 \%$ in fish from Stations 316 and 317 (fig. 16). The HSI values in channel catfish were $0.8-1.7 \%$ in the MRB and $1.9-2.2 \%$ in the RGB (BEST-LRMN Program, unpublished data). The HSI values in CDRB channel catfish were normal (1-3\%) according to Gingerich (1982).

SSI values in channel catfish differed among stations $\left(F_{5}\right.$, $\left.{ }_{73}=2.69, P<0.05\right)$ but not between genders $\left(F_{1,73}=0.00, P>\right.$ $0.05)$. The basin-wide mean SSI value in channel catfish was $0.15 \%$, and station means ranged from $0.08 \%$ at Station 324 to $0.20 \%$ at Station 315 (table 21). SSI values were $>0.4 \%$ in fish from Stations 315 and 317. Relatively low SSI values $(<0.07 \%)$ characterized fish from Station 324 (fig. 16), but spleen tissue in these fish were histologically normal. The SSI values in CDRB channel catfish were similar to those measured in previous LRMN investigations. SSI values in channel catfish were $0.14-0.17 \%$ in the MRB and $0.03-0.77 \%$ in the RGB (BEST-LRMN program, unpublished data). Fish health indicators for non-target species are located in Appendix 7.

\section{Cellular and Histopathological Indicators}

Macrophage aggregates (MAs) contain endogenous and exogenous waste products and are active in the immune response to these materials (Schmitt and Dethloff, 2000). Three MA parameters, density or number of aggregates per $\mathrm{mm}^{2}$ (MA-\#), mean size of aggregates in $\mu \mathrm{m}^{2}$ (MA-A), and percent of tissue occupied by macrophage aggregates (MA-\%) were analyzed for carp, bass, and channel catfish.

MA parameters were quantified using computer-based image analysis in spleen tissues from Stations 311, 313, 314, $316,317,321,322,323$, and 325 and manually digitized microscopic analysis in spleen tissues from Stations 312, 315, 319, 320, and 324. MAs in bass and channel catfish from Stations 312 and 315 were quantified using both methods. Manually digitized measurements were significantly lower than computer-based image measurements for MA-\# in bass from Station $312\left(t_{7}=4.06, P=0.005\right)$ and channel catfish from Station $315\left(t_{4}=3.20, P=0.03\right)$ and MA-A in bass from Station $315\left(t_{11}=2.80, P=0.02\right)$ and channel catfish from Station 312 $\left(t_{10}=4.04, P=0.002\right)$. However, MA- $\%$ calculations did not differ significantly between methods. Differences in the methods were not consistent among species or MA parameter. In general, manually digitized measurements provided estimates that were less than the estimates obtained with computer-based image measurements, but differences were not always significant. Therefore, MA data from Stations 312, 315, 319, 320, and 324 were excluded from statistical modeling. 
Table 22. Arithmetic mean of the hepatosomatic index (HSI; \%) by species and station in bass and channel catfish collected in the Colorado River Basin in 2003. Number of samples $(n)$, minimum (Min), maximum (Max), and standard error (SE) are also given. Stations are ordered upstream to downstream. The maximum station mean for each taxon is shown in bold.

\begin{tabular}{|c|c|c|c|c|c|}
\hline \multirow{2}{*}{ Taxon and station } & \multicolumn{5}{|c|}{ Hepatosomatic index (HSI) } \\
\hline & $n$ & Mean & Min & Max & SE \\
\hline \multicolumn{6}{|l|}{ Bass } \\
\hline Basin Total & 117 & 1.15 & 0.36 & 3.00 & 0.04 \\
\hline Lay, CO (311) & 20 & 1.73 & 0.69 & 3.00 & 0.11 \\
\hline Ouray NWR, UT (312) & 14 & 0.66 & 0.36 & 0.93 & 0.04 \\
\hline Loma, CO (315) & 12 & 1.43 & 1.03 & 1.84 & 0.07 \\
\hline Needles, CA (321) & 20 & 0.85 & 0.59 & 1.30 & 0.04 \\
\hline Imperial Dam, AZ (322) & 20 & 0.96 & 0.48 & 1.68 & 0.07 \\
\hline Hayden, AZ (323) & 9 & 1.23 & 0.80 & 1.65 & 0.10 \\
\hline Phoenix, AZ (324) & 2 & 1.39 & 0.84 & 1.94 & 0.55 \\
\hline Arlington, AZ (325) & 20 & 1.14 & 0.64 & 1.58 & 0.06 \\
\hline \multicolumn{6}{|l|}{ Channel Catfish } \\
\hline Basin Total & 88 & 1.45 & 0.87 & 2.79 & 0.04 \\
\hline Ouray NWR, UT (312) & 11 & 1.53 & 1.08 & 2.79 & 0.15 \\
\hline San Rafael, UT (313) & 18 & 1.73 & 1.29 & 2.32 & 0.07 \\
\hline Loma, CO (315) & 5 & 1.33 & 1.15 & 1.64 & 0.09 \\
\hline Gold Bar Canyon, UT (316) & 20 & 1.31 & 0.97 & 1.78 & 0.05 \\
\hline Hogback Diversion, NM (317) & 20 & 1.36 & 0.87 & 2.06 & 0.07 \\
\hline Phoenix, AZ (324) & 14 & 1.42 & 1.07 & 1.85 & 0.06 \\
\hline
\end{tabular}

The MA parameters varied significantly in both bass and carp based on the collection station and age of the fish (and the interaction of these factors; ANOVA, Appendix 6). Station, gender, and age of the fish were not significant factors influencing MA parameters in channel catfish. Female and male fish were analyzed together in all three taxa because MA parameters did not differ between genders. Age was a significant factor in some species and is discussed where appropriate. MA parameters from all stations were included in the tables and figures because of the differences in methodology reported previously.

\section{MA measurements in carp}

The basin-wide mean MA-\# value was $7.0 \mathrm{MA} / \mathrm{mm}^{2}$ in CDRB carp, and station means ranged from $4.1 \mathrm{MA} / \mathrm{mm}^{2}$ at Stations 314 and 315 to $10.9 \mathrm{MA} / \mathrm{mm}^{2}$ at Station 316 (table 23). The mean MA-\# was also $>10 \mathrm{MA} / \mathrm{mm}^{2}$ at Stations 313 and 322, but the MA-\# in a carp from Station 311 was low $\left(0.6 \mathrm{MA} / \mathrm{mm}^{2}\right)$. Relatively high MA-\# values $\left(>15 \mathrm{MA} / \mathrm{mm}^{2}\right)$ were measured in fish from Stations 313, 316, 322, and 325 (fig. 17). Overall, MA-\# values in CDRB carp were similar to those from previous LRMN studies. Mean MA-\# values in carp were 5.1-18.3 MA/mm² in the MRB (Blazer and others,
2002), 1-16 MA/mm ${ }^{2}$ in the RGB (Schmitt and others, 2004), and 3.0-10.2 MA/mm² in the CRB (Hinck and others, 2004a).

The size of MAs in carp differed among CDRB stations. Stations means were 2,349-5,596 $\mu^{2}$ except at Stations 319 $\left(9,764 \mu \mathrm{m}^{2}\right)$ and $320\left(11,463 \mu \mathrm{m}^{2}\right.$; table 23$)$. The MA-A values were $>15,000 \mu \mathrm{m}^{2}$ in multiple fish from these two stations (fig. 17), and these fish were also among the oldest collected (table 7). The MA-As in carp from Stations 319 and 320 were the greatest documented by the LRMN. Mean MA-A values in carp were 1,670-4,684 $\mu \mathrm{m}^{2}$ in the MRB (Blazer and others, 2002), 1,500-8,000 $\mathrm{um}^{2}$ in the RGB (Schmitt and others, 2004), and 2,690-5,850 $\mu^{2}$ in the CRB (Hinck and others, 2004a).

Similar to MA-A values, mean MA- $\%$ values were greatest (>6\%) in carp from Stations 319 and 320 (table 23). Other station means ranged from $1.8 \%$ at Stations 312 and 314 to $4.7 \%$ at Station 316 (table 23), and an MA- $\%$ value of $0.1 \%$ was calculated for carp from Station 311. The MA-\% values were $>10 \%$ in numerous fish from Stations 319 and 320, which is consistent with the high MA-A values from these stations (fig. 17). Mean MA-\% values were $1.2-6.4 \%$ in the MRB (Blazer and others, 2002), 1-13\% in the RGB (Schmitt and others, 2004), and $0.9-4.7 \%$ in the CRB (Hinck and others, 2004a). 


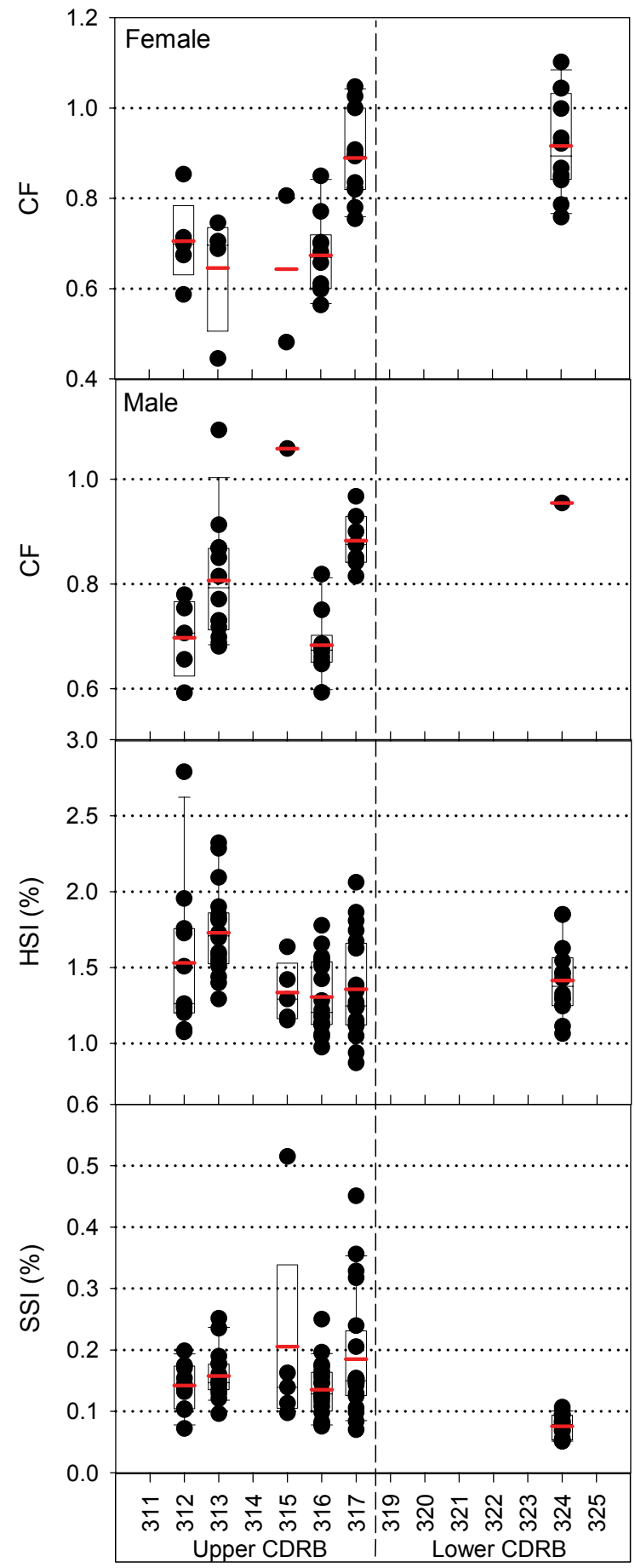

Station

Figure 16. Fish health indicators by station in female and male channel catfish from the Colorado River Basin in 2003. Indicators include condition factor (CF), hepatosomatic index (HSI), and splenosomatic index (SSI). Shown for each group are points representing individual fish and the mean (red horizontal line), median (black horizontal line), interquartile range (box), and the 10th and 90th percentiles (whiskers). Stations are ordered from upstream to downstream and are grouped by sub-basin. See Table 2 for station descriptions.
The size of MAs in carp from Stations 319 and 320 were larger, but not more numerous, than those from other CDRB stations. MA parameters have been positively correlated with age in previous studies, and carp from Stations 319 and 320 were relatively old ( $>30 \mathrm{y}$ ). Therefore, age is an important factor to consider when interpreting these data. However, MA parameters did not appear anomalous in relatively old carp (>20 y) from Stations 313, 316, and 321.

\section{MA measurements in bass}

The basin-wide mean density of MAs in bass (2.3 MA/ $\left.\mathrm{mm}^{2}\right)$ was less than in carp $\left(7.0 \mathrm{MA} / \mathrm{mm}^{2}\right)$. Station means ranged from $0.7 \mathrm{MA} / \mathrm{mm}^{2}$ at Station 312 to $5.5 \mathrm{MA} / \mathrm{mm}^{2}$ at Station 324 and were generally less in fish from the Upper CDRB compared to those from the Lower CDRB (table 23). Mean MA-\# values were relatively low $\left(<0.9 \mathrm{MA} / \mathrm{mm}^{2}\right)$ at Stations 311,312 , and 315 , and values were $\geq 6 \mathrm{MA} / \mathrm{mm}^{2}$ in fish from Stations 321, 322, 324, 325 (fig. 18). Age was a significant factor in the ANOVA model, but large MAs $(\geq 6$ $\mathrm{MA} / \mathrm{mm}^{2}$ ) were measured in fish from various age classes (1 to $11 \mathrm{y}$ ). Overall, MA-\# values in the CDRB were generally less than those from previous LRMN studies. Mean MA-\# values in bass were 2.2-11.2 MA/mm ${ }^{2}$ in the MRB (Blazer and others, 2002), 4-8 MA/mm ${ }^{2}$ in the RGB (Schmitt and others, 2004), and 4.1-9.5 MA/mm $\mathrm{mm}^{2}$ in the CRB (Hinck and others, 2004a).

Bass from the Upper CDRB not only had fewer numbers of MAs but also smaller MAs (table 23). Station means were 612-2,317 $\mu \mathrm{m}^{2}$ in the Upper CDRB compared to 3,994-9,389 $\mu \mathrm{m}^{2}$ in the Lower CDRB (table 23). The MA-A values were $>15,000 \mu \mathrm{m}^{2}$ in bass from Stations 321, 323, and 325 (fig. 18). MA-A values in bass from the Lower CDRB (Stations 323, 324 , and 325) were generally greater than those from previous LRMN studies. Mean MA-A values in bass were 1,049-4,440 $\mu \mathrm{m}^{2}$ in the MRB (Blazer and others, 2002), 3,000-5,000 $\mu \mathrm{m}^{2}$ in the RGB (Schmitt and others, 2004), and 2,118-5,095 $\mu \mathrm{m}^{2}$ in the CRB (Hinck and others, 2004a).

Mean MA-\% values were lower $(<0.5 \%)$ in bass from Stations 311, 312, and 315 and greater $(>1.6 \%)$ in bass from Stations 321, 322, 323, 324, and 325 (table 23). Individual MA- $\%$ values were $>6 \%$ in bass from Stations 321, 322, and 323 (fig. 18). Age was a significant factor in the statistical model, but large MAs were measured in fish from various age classes (2-11 y). The MA-\% values in CDRB bass were generally less than those measured in bass from previous LRMN studies. Mean MA-\% values were $0.3-3.8 \%$ in the MRB (Blazer and others, 2002), 2-3\% in the RGB (Schmitt and others, 2004), and 1.1-4.0\% in the CRB (Hinck and others, 2004a).

In general, all MA parameters were lower in bass from Stations 311, 312, and 315 in the Upper CDRB than those from Stations 321, 322, 323, 324, and 325 in the Lower CDRB. However, mean MA measurements in bass were lower than those from the MRB, RGB, and CRB. Age was a significant factor in the statistical model, but relatively high 
Table 23. Arithmetic mean of macrophage aggregate (MA) density (MA-\#), MA area (MA-A), and percent tissue occupied by MA (MA-\%) by taxon and station in carp, bass, and channel catfish from the Colorado River Basin in 2003. Number of samples $(n)$, minimum (Min), maximum (Max), and standard error (SE) are also given. Stations are grouped by taxon and ordered upstream to downstream. The maximum station mean for each taxon is shown in bold. Measurements from Stations 312, 315, 319, 320, and 324 were made using manual microscopic analysis; measurements from other stations were made using computer-based image analysis. ,-- not applicable.

\begin{tabular}{|c|c|c|c|c|c|c|c|c|c|c|c|c|c|}
\hline \multirow{2}{*}{ Taxon and station } & \multirow[b]{2}{*}{$n$} & \multicolumn{4}{|c|}{ MA-\# (MA/mm²) } & \multicolumn{4}{|c|}{ MA-A $\left(\mu \mathrm{m}^{2}\right)$} & \multicolumn{4}{|c|}{ MA- $\%(\%)$} \\
\hline & & Mean & Min & Max & SE & Mean & Min & Max & SE & Mean & Min & Max & SE \\
\hline \multicolumn{14}{|l|}{ Carp } \\
\hline Basin Total & 260 & 7.0 & 0.0 & 25.3 & 0.27 & 4847 & 0 & 34549 & 271 & 3.4 & 0.0 & 23.9 & 0.20 \\
\hline Lay, CO (311) & 1 & 0.6 & -- & -- & -- & 2349 & -- & -- & -- & 0.1 & -- & -- & -- \\
\hline Ouray NWR, UT (312) & 20 & 5.3 & 0.0 & 9.4 & 0.54 & 2842 & 0 & 8101 & 433 & 1.8 & 0.0 & 6.4 & 0.34 \\
\hline San Rafael, UT (313) & 21 & 10.5 & 1.2 & 25.3 & 1.36 & 4244 & 650 & 8147 & 459 & 4.5 & 0.1 & 9.2 & 0.59 \\
\hline Delta, CO (314) & 21 & 4.1 & 1.2 & 8.8 & 0.47 & 4369 & 1663 & 14532 & 593 & 1.8 & 0.5 & 8.8 & 0.40 \\
\hline Loma, CO (315) & 20 & 4.1 & 0.0 & 10.9 & 0.65 & 3526 & 0 & 7881 & 538 & 2.0 & 0.0 & 6.2 & 0.41 \\
\hline Gold Bar Canyon, UT (316) & 20 & 10.9 & 6.5 & 19.4 & 0.79 & 4414 & 1749 & 10518 & 461 & 4.7 & 1.3 & 9.6 & 0.46 \\
\hline Hogback Diversion, UT (317) & 20 & 6.3 & 2.9 & 11.8 & 0.52 & 4517 & 1247 & 10346 & 551 & 3.0 & 0.4 & 7.5 & 0.44 \\
\hline South Cove, AZ (319) & 17 & 5.8 & 0.0 & 8.8 & 0.51 & 9764 & 0 & 34549 & 2307 & 6.6 & 0.0 & 23.9 & 1.67 \\
\hline Willow Beach, AZ (320) & 20 & 5.5 & 2.8 & 8.1 & 0.36 & 11463 & 3902 & 29113 & 1503 & 6.1 & 1.4 & 14.4 & 0.89 \\
\hline Needles, CA (321) & 20 & 7.7 & 2.4 & 14.7 & 0.72 & 5596 & 2121 & 10909 & 474 & 4.0 & 1.7 & 7.0 & 0.31 \\
\hline Imperial Dam, AZ (322) & 20 & 10.5 & 2.4 & 23.5 & 1.21 & 4002 & 1974 & 11570 & 565 & 4.2 & 0.7 & 16.3 & 0.76 \\
\hline Hayden, AZ (323) & 20 & 6.6 & 0.0 & 14.1 & 0.93 & 2926 & 0 & 10236 & 486 & 2.1 & 0.0 & 6.2 & 0.37 \\
\hline Phoenix, AZ (324) & 20 & 5.0 & 0.0 & 7.5 & 0.43 & 3487 & 0 & 6439 & 345 & 2.0 & 0.2 & 3.1 & 0.18 \\
\hline Arlington, AZ (325) & 20 & 8.9 & 1.2 & 19.4 & 1.11 & 2779 & 795 & 5194 & 295 & 2.5 & 0.2 & 9.5 & 0.45 \\
\hline \multicolumn{14}{|l|}{ Bass } \\
\hline Basin Total & 117 & 2.3 & 0 & 10.6 & 0.20 & 4513 & 0 & 19762 & 402 & 1.4 & 0.0 & 10.3 & 0.17 \\
\hline Lay, CO (311) & 20 & 0.9 & 0.0 & 2.9 & 0.18 & 2317 & 0 & 6994 & 427 & 0.3 & 0.0 & 1.5 & 0.08 \\
\hline Ouray NWR, UT (312) & 14 & 0.7 & 0.0 & 1.3 & 0.11 & 612 & 0 & 1570 & 117 & 0.1 & 0.0 & 0.3 & 0.02 \\
\hline Loma, CO (315) & 12 & 0.8 & 0.0 & 5.3 & 0.45 & 1948 & 0 & 13843 & 1168 & 0.5 & 0.0 & 2.9 & 0.29 \\
\hline Needles, CA (321) & 20 & 3.7 & 0.6 & 7.7 & 0.40 & 7196 & 2243 & 18628 & 969 & 2.9 & 0.2 & 7.0 & 0.47 \\
\hline Imperial Dam, AZ (322) & 20 & 3.3 & 0.6 & 10.6 & 0.73 & 3994 & 1338 & 11756 & 564 & 1.6 & 0.1 & 7.1 & 0.42 \\
\hline Hayden, AZ (323) & 9 & 2.7 & 0.6 & 5.3 & 0.66 & 9389 & 2803 & 19762 & 2067 & 2.7 & 0.3 & 10.3 & 1.06 \\
\hline Phoenix, AZ (324) & 2 & 5.5 & 5.0 & 5.9 & 0.47 & 6992 & 6415 & 7568 & 577 & 3.5 & 3.5 & 3.6 & 0.08 \\
\hline Arlington, AZ (325) & 20 & 2.8 & 0.6 & 5.9 & 0.35 & 6371 & 869 & 17354 & 916 & 1.7 & 0.1 & 4.6 & 0.27 \\
\hline \multicolumn{14}{|l|}{ Channel catfish } \\
\hline Basin Total & 89 & 1.4 & 0.0 & 10.0 & 0.17 & 2741 & 0 & 25823 & 327 & 0.4 & 0.0 & 2.2 & 0.05 \\
\hline Ouray NWR, UT (312) & 11 & 1.4 & 0.0 & 5.9 & 0.54 & 1236 & 0 & 3995 & 427 & 0.4 & 0.0 & 2.0 & 0.17 \\
\hline San Rafael, UT (313) & 18 & 0.9 & 0.6 & 1.8 & 0.10 & 4508 & 976 & 25823 & 1356 & 0.4 & 0.1 & 1.6 & 0.10 \\
\hline Loma, CO (315) & 5 & 1.3 & 0.0 & 2.8 & 0.49 & 932 & 0 & 1618 & 284 & 0.3 & 0.0 & 0.5 & 0.08 \\
\hline Gold Bar Canyon, UT (316) & 20 & 2.3 & 0.6 & 10.0 & 0.58 & 3213 & 1056 & 5774 & 317 & 0.7 & 0.1 & 2.2 & 0.14 \\
\hline Hogback Diversion, UT (317) & 20 & 1.0 & 0.6 & 2.4 & 0.14 & 3153 & 643 & 6439 & 386 & 0.3 & 0.0 & 1.1 & 0.06 \\
\hline Phoenix, AZ (324) & 15 & 1.4 & 0.0 & 4.7 & 0.34 & 1342 & 0 & 4776 & 351 & 0.4 & 0.0 & 1.3 & 0.12 \\
\hline
\end{tabular}

MA parameters were measured in fish of various age classes (1-11 y).

\section{MA measurements in channel catfish}

The MA measurements in channel catfish were the lowest of the target species. The basin-wide mean for MA-\# was 1.4 MA/mm ${ }^{2}$, and station means ranged from $0.9 \mathrm{MA} / \mathrm{mm}^{2}$ at
Station 313 to $2.3 \mathrm{MA} / \mathrm{mm}^{2}$ at Station 316 (table 23). Values were $\geq 6 \mathrm{MA} / \mathrm{mm}^{2}$ only in fish from Station 316 (fig. 19). MA size was generally small. Mean MA-A values ranged from $932 \mu \mathrm{m}^{2}$ at Station 315 to $4,508 \mu \mathrm{m}^{2}$ at Station 313 (table 23). Fish from Station 313 had a few, very large MAs. The MA-A values were relatively high $\left(>5,000 \mu \mathrm{m}^{2}\right)$ in fish from Stations 313, 316, and 317 (fig. 19). The MA-\% values in channel catfish were similar among stations. Mean MA-\% values were 


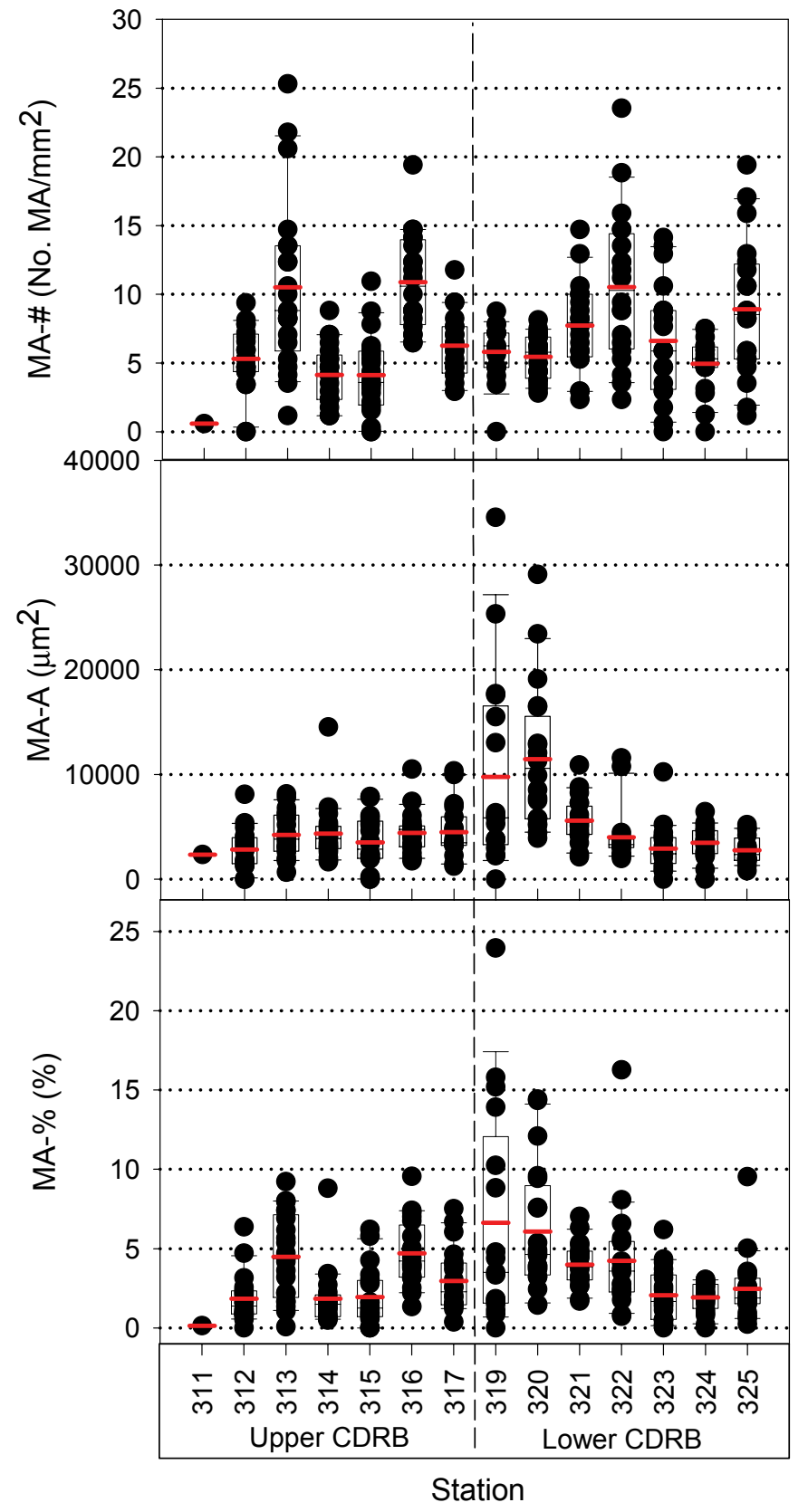

Figure 17. Splenic macrophage aggregate parameters by station in female and male carp from the Colorado River Basin in 2003. Parameters include macrophage aggregate density (MA-\#), macrophage aggregate area (MA-A), and percent of splenic tissues occupied by macrophage aggregates (MA-\%). Shown for each group are points representing individual fish and the mean (red horizontal line), median (black horizontal line), interquartile range (box), and the 10th and 90th percentiles (whiskers). Stations are ordered from upstream to downstream and are grouped by sub-basin. See Table 2 for station descriptions. $\leq 0.4 \%$ at all stations except Station 316 (table 23), and MA-\% values were $>1.5 \%$ in fish from Stations 312, 313, and 316 . MAs were generally larger but less numerous in CDRB channel catfish compared to MAs in channel catfish from a previous study (Matsche and Grizzle, 1999); however, fish from the Matsche and Grizzle study were younger ( $<5$ months) than CDRB fish.

\section{General Histopathology}

Gill, liver, gonad, spleen, head kidney, hind kidney, and lesion tissues were collected for histopathological examination during the field examination. Results were limited to Stations $312,315,319,320$, and 324 and summarized by tissue.

Gill tissues were typically taken from the second or third gill arch and were normal in most fish with a few exceptions. Mild basal hyperplasia of the lamellar epithelium was noted in carp from Stations 312 and 320 and channel catfish from Station 312. Edema, parasites, and fused lamellae were also found in carp from Station 320. Most aneurysms in the gills were likely trauma induced from collection and processing, but aneurysms in several fish from Stations 315 and 319 showed thrombosis, which were considered pathological anomalies.

Liver tissues were normal in most CDRB fish evaluated. A large granuloma with calcification was found in a channel catfish from Station 312 and was likely parasitic in origin. Extensive parasitic infestations of helminth parasites were identified in the livers of largemouth bass from all sites. Lesions from trematodes were typically mild to severe, and myxosporean were minimal to mild. Parasites were degenerating surrounding tissues and creating calcified areas in some tissues. Occasionally, associated granulomas were observed in these same liver tissues. Cystic and proliferated bile ducts, hypertrophy, and MAs were found in carp liver tissues from Station 320.

Gonadal tissues were examined for the presence of ovotestes and quantification of oocyte atresia. Encysted parasites, associated lesions, or both were common in female and male gonads of largemouth bass from Stations 312, 315, 319, 320 , and 324. Pigmented cell accumulations were found in multiple carp from Station 320, and ova containing fluid were described for several female carp from Station 319. Anomalies in gonadal tissues were described in many carp and channel catfish from Station 324; calcification, poorly developed testes, edema, and parasites were the most common abnormalities observed in the gonadal tissues of fish from Station 324.

Histopathological conditions in splenic tissue (other than MAs) were rare in CDRB fish. Splenic tissues were analyzed for MAs, as discussed previously (see previous section). Parasitic infestations in largemouth bass were similar but less prevalent to those described in liver tissues. A large hematoma was observed in a carp from Station 312, and edema was observed in two carp (Stations 315 and 319).

Anomalies were observed in head and hind kidney tissues of all species collected in the CDRB. MAs were common in 


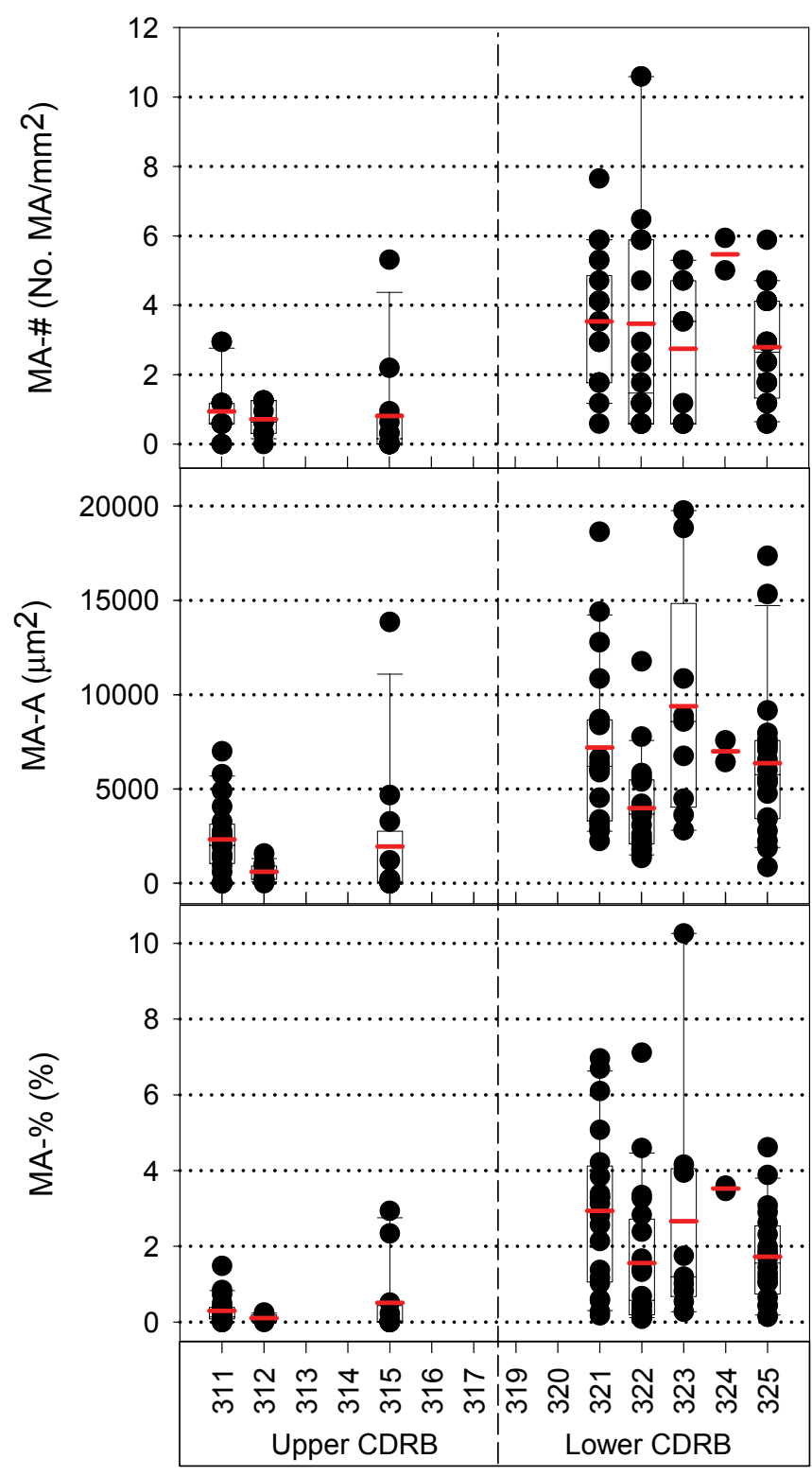

Station

Figure 18. Splenic macrophage aggregate parameters by station in female and male bass (Micropterus sp.) from the Colorado River Basin in 2003. Parameters include macrophage aggregate density (MA-\#), macrophage aggregate area (MAA), and percent of splenic tissues occupied by macrophage aggregates (MA-\%). Shown for each group are points representing individual fish and the mean (red horizontal line), median (black horizontal line), interquartile range (box), and the 10th and 90th percentiles (whiskers). Stations are ordered from upstream to downstream and are grouped by sub-basin. See Table 2 for station descriptions.

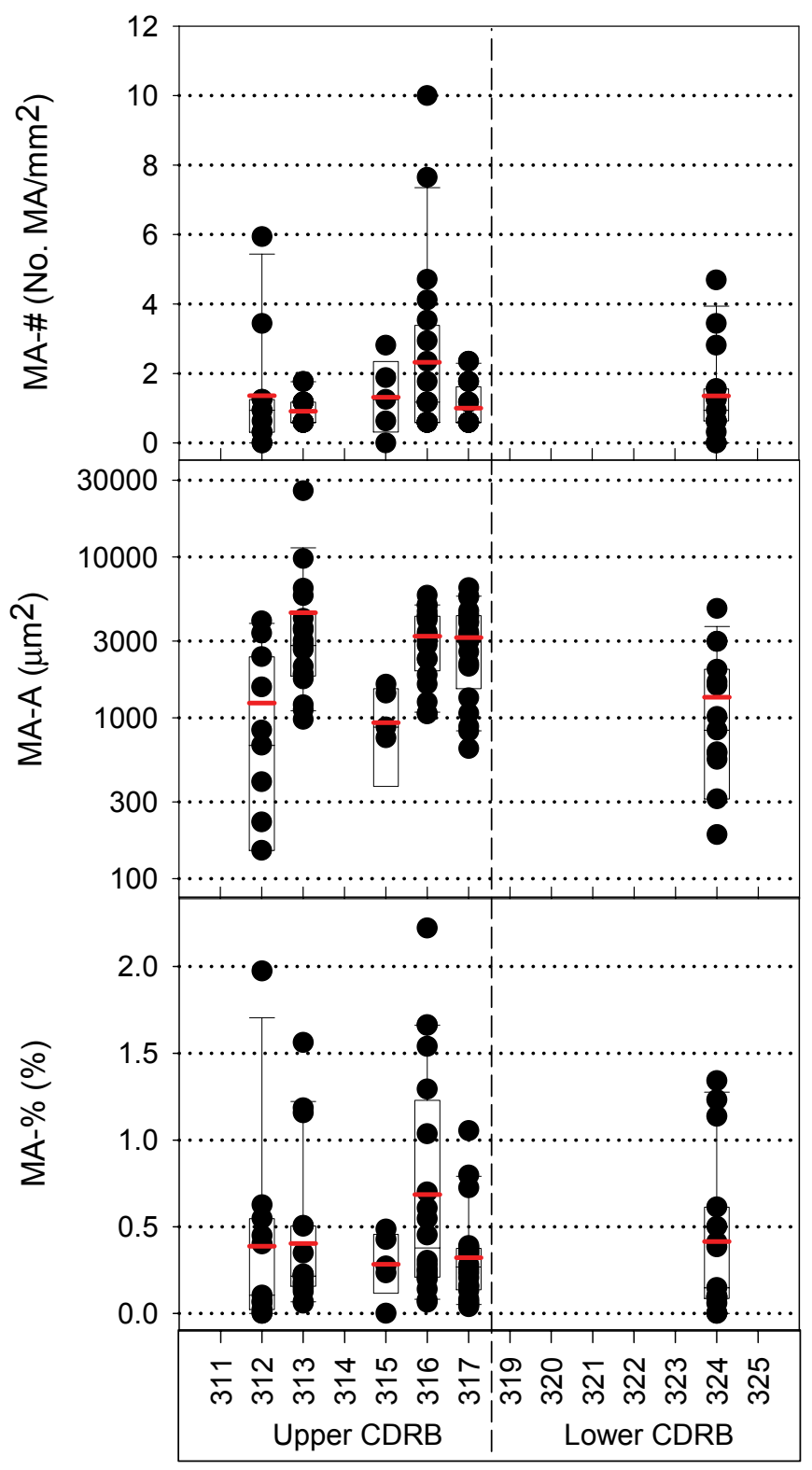

Station

Figure 19. Splenic macrophage aggregate parameters by station in female and male channel catfish from the Colorado River Basin in 2003. Parameters include macrophage aggregate density (MA-\#), macrophage aggregate area (MA-A), and percent of splenic tissues occupied by macrophage aggregates (MA$\%)$. Shown for each group are points representing individual fish and the mean (red horizontal line), median (black horizontal line), interquartile range (box), and the 10th and 90th percentiles (whiskers). Stations are ordered from upstream to downstream and are grouped by sub-basin. See Table 2 for station descriptions. 
kidney tissues of all species. Ectopic thyroid follicles (TFs) were also common in the head and hind kidney of carp from all stations evaluated, but TFs were not found in bass or channel catfish. TFs differed in size, were filled with eosinophilicstaining colloid (caused by a reserve of thyroglobulin), and were generally surrounded by flattened squamous epithelium. Active TFs are usually surrounded by tall cuboidal or columnar epithelial cells and may contain less colloid (Fournie and others, 2005). The TFs in the hind kidney were generally smaller but more numerous than those found in the head kidney. Similar to liver and spleen tissues, parasites and associated lesions were prevalent in head and hind kidney tissues of largemouth bass. Crystallization, calcification, or both were observed in hind kidney tubules of multiple carp from Station 320. Hyaline droplet degeneration was also found in the hind kidney of five female channel catfish from Station 324.

\section{Fish Health Indicators: Summary}

The fish health indicators, which can be affected by various factors including age, gender, reproductive status, geographic location, and contaminants, were selected to reflect overall organismal health of the fish and their populations. Most of the endpoints measured in CDRB fish were limited to the target species (that is, carp, bass, and channel catfish) to remain consistent with other portions of the study. However, some endpoints were measured in all species.

The occurrence of external lesions has been used to evaluate fish health in freshwater and estuarine systems (Fournie and others, 1996; Sanderson and van den Berg, 1999). Fin erosion (Cross, 1985; Lindesjoo and Thulin, 1990; Murchelano and Ziskowski, 1982; Reash and Berra, 1989), skin and liver tumors (Baumann and others, 1991; Malins and others, 1988; Vogelbein and others, 1990), and skeletal deformities (Bengtsson, 1979; Bengtsson and others, 1985; Mehrle and others, 1982) are commonly associated with degraded environments. Errors in proportions of anomalous fish can result from biased or differential examination of fish, species composition, habitat, and other factors unrelated to environmental degradation (Leonard and Orth, 1986). This study evaluated abnormalities of the body surface, eyes, opercles, and fins, including deformities and parasites. Thus, comparisons of this data to other studies must also consider the type of anomaly considered in each examination.

In general, the proportion of CDRB fish with external lesions was lower compared to previous LRMN studies (Blazer and others, 2002; Hinck and others, 2004a; Schmitt and others, 2004). Overall, more lesions were identified on fish from the Upper CDRB than those from the Lower CDRB, and high proportions of lesion occurrence $(\geq 70 \%)$ were reported in carp from Station 312 and bass and channel catfish from Station 315. Body surface nodules and frayed fins were the most common external lesions identified in CDRB fish. Most nodules were inflammatory responses to parasitic infestations, and frayed fins may result from normal wear as a fish ages. Tumors were found in several fish. A hematoma on an opercle was identified on a carp from Station 324, and fibrotic fin lesions with inflammation and increased numbers of melanocytes were identified on two carp from Station 320. A fibroma and papilloma were observed on catfish from Station 313, and a papilloma was observed on a bass and a carp from Station 321.

The HAI, which is also an assessment of grossly visible lesions, is more comprehensive than the incidence of external lesions because it accounts for both external and internal abnormalities. The HAI in carp and bass has been used in previous studies (Adams and others, 1993; Coughlan and others, 1996; Blazer and others, 2002; Schmitt and others, 2004; Hinck and others, 2004a) but has had limited use in channel catfish (BEST-LRMN program, unpublished data). Mean HAI scores from the CDRB were 15-70 in carp, 19-103 in bass, 14-81 in channel catfish, and relatively high HAI scores were calculated for carp and bass from the Lower CDR. Liver discoloration, granular spleen and kidney, and pale gills accounted for most elevated HAI scores in carp from Stations 319, 320, 321, and 322. Liver discoloration, granular liver, kidney, and spleen, and body surface lesions elevated HAI scores in bass from Station 315, 321, and 322. The HAI scores in bass were greater than those measured previously in bass from other LRMN studies (Blazer and others, 2002; Hinck and others, 2004a; Schmitt and others, 2004) and would be considered unhealthy or contaminated by criteria from other studies (Adams and others, 1993; Coughlan and others, 1996). The relatively high HAI scores for carp and bass in the Lower CDR indicate that these fish were in generally poorer health than those from other CDRB stations.

Condition factor may indicate changes at the organism level and is directly affected by nutrition, season, sexual maturation, and disease (Adams and others, 1982; Denton and Yousef, 1976; Möller, 1985; Tyler and Dunn, 1976). High CF values have been associated with contaminant exposure such as pulp mill effluent (Adams and others, 1992a; McMaster and others, 1991; Oakes and others, 2004) and municipal sewage effluent (Oakes and others, 2004), whereas lower CF values have been observed after exposure to contaminants such as metals and petroleum (Kiceniuk and Khan, 1987; Miller and others, 1992; Munkittrick and Dixon, 1988). Condition factor can also vary among locations within a species (Doyon and others, 1988; Fisher and others, 1996). Relatively low CF values were calculated for carp from Stations 314, 315, and $321(<0.8)$ and bass from Stations 315 and $321(<1.0)$, and these values were also lower than those measured in fish from other studies (Blazer and others, 2002; Carlander, 1969, 1977; Hinck and others, 2004a; Schmitt and others, 2004; Sepúlveda and others, 2001). Selenium concentrations in carp and bass from Stations 314, 315, and 321 were among the highest measured in our study $(>2.0 \mu \mathrm{g} / \mathrm{g})$, and may be associated with low CF values in fish from these sites (Hamilton, 2004).

The HSI can vary with season (Beamish and others, 1996; Delahunty and de Vlaming, 1980), temperature (Fine and others, 1996), nutrition (Daniels and Robinson, 1986; Foster and others, 1993), gender, and reproductive status 
(Fabacher and Baumann, 1985; Förlin and Haux, 1990; Grady and others, 1992). Changes in HSI have often been associated with contaminant exposure (Adams and McLean, 1985). Increased HSI values have been reported with exposure of wild fish to organic contaminants, most often PAHs and PCBs, whereas laboratory exposures of fish to metals, crude oil, certain pesticides, and bleached kraft mill effluent have resulted in HSI decreases (Schmitt and Dethloff, 2000). Other studies have reported that HSI increased in largemouth bass after exposure to bleached/unbleached kraft mill effluent (Sepúlveda and others, 2001, 2003). A comparative range for normal liver weight in fish is $1-3 \%$ of body weight, with relative weights $>2 \%$ being uncommon (Gingerich, 1982). Mean HSI values were $<1.0 \%$ in bass from Stations 312, 321, and 322 but were not related to gonadal stage. Similar HSI values in bass were reported in previous LRMN studies (Blazer and others, 2002; Hinck and others, 2004a; Schmitt and others, 2004). Histopathological examination determined liver tissue from Stations 321 and 322 has high parasites loads and fatty vacuolization.

The SSI can differ among species, genders, and locations and change over age, size, gonadal development, and season (Krykhtin, 1976; Ruklov, 1979; White and Fletcher, 1985). Fish exposed to organic contaminants alone or in combination with metals had decreased SSI values (Kiceniuk and Khan, 1987; Payne and others, 1978; Pulsford and others, 1995), but increased SSI values have rarely been documented with contaminant exposure (Adams and others, 1992b). An increase in relative spleen size is considered indicative of disease or immune problems (Goede and Barton, 1990). Capture and holding stress during field studies can also alter SSI and HSI (Schmitt and Dethloff, 2000). The SSI values in carp and channel catfish were similar to those measured in previous LRMN studies, but values in CDRB bass were generally lower than those from other studies (Blazer and others, 2002; Hinck and others, 2004a; Schmitt and others, 2004). Relatively low SSI values were observed in bass and channel catfish from Station 324, but histopathology determined spleen tissue was normal in these fish. Decreased spleen sizes have been associated with hypoxia as well as exposure to PCBs, PAHs, and metals (see Schmitt and Dethloff, 2000). Relatively high PCB concentrations $(>1.0 \mu \mathrm{g} / \mathrm{g})$ were measured in fish from Station 324 , and wastewater treatment plant effluent and urban runoff from the Phoenix area comprises much of the water in the GR near Station 324 (Anning, 2003; Arnold and others, 2004; Gebler, 1998). These factors may have affected SSI values in fish from Station 324.

Various factors including size, nutritional status (Agius, 1979, 1980; Agius and Roberts, 1981; Wolke and others, 1985), age (Blazer and others, 1987; Brown and George, 1985; Couillard and Hodson, 1996), and exposure time (Schmitt and Dethloff, 2000) can affect MAs in different species. Increases in MA parameters in fish from specific contaminated sites relative to reference sites have been documented in both laboratory and field studies (Blazer and others, 1994; Blazer and others, 1997; Wolke, 1992). The USEPA Environmental Mon- itoring and Assessment Program (EMAP) Estuaries Program (Fournie and others, 2001; Summers and others, 1993) and National Oceanic and Atmospheric Administration's Status and Trends Program (Chang and others, 1998) have also used MA parameters as bioindicators. MAs have been identified in various tissues including spleen, liver, gonad, and kidney, and many studies using splenic MAs have been performed in marine or estuarine environments but not in freshwater environments. Splenic MA-\# >40 MA/mm² were correlated with hypoxic stress or high levels of sediment contamination in estuarine fishes of varying age (Fournie and others, 2001). More information is needed to interpret values in freshwater fishes.

MAs were generally larger and more numerous in carp than in bass or channel catfish. MAs were $>15,000 \mu \mathrm{m}^{2}$ in multiple carp from Stations 319 and 320, and these were the largest MAs measured in any LRMN study (Blazer and others, 2002; Hinck and others, 2004a; Schmitt and others, 2004). Carp from Stations 319 and 320 were relatively old (>35 y). However, smaller MAs $\left(<7,000 \mu \mathrm{m}^{2}\right)$ were measured in other CDRB carp $>35 \mathrm{y}$. MA parameters were generally lower in bass from Stations 311, 312, and 315 in the Upper CDRB than those from Stations 321, 322, 323, 324, and 325 in the Lower CDRB. Mean MA measurements were lower than those from the MRB, RGB, and CRB studies (Blazer and others, 2002; Hinck and others, 2004a; Schmitt and others, 2004).

MAs were examined but not quantified in other tissues from Stations 312, 315, 319, 320, and 324. MAs were common in the head and hind kidney of carp, bass, and channel catfish from all stations. Pigmented cell accumulations were also found in gonadal tissue of several male and female carp from Stations 319 and 320. MAs in carp gonads have been reported previously in Lake Mead (Patiño and others, 2003b). Patiño and others (2003b) suggested that high incidences of testicular MAs were correlated with lower GSI values in males and may be caused by exposure to environmental contaminants; however, infectious diseases can also increase MAs in fish tissues (Wolke, 1992). Histopathological examination also revealed TFs were common in head and hind kidney tissues of carp, but the size and number of TFs differed between tissues and among sites. TFs in the hind kidney of carp have described in previous LRMN investigations (Blazer and others, 2002; Schmitt and others, 2004). Perchlorate, a known contaminant in the Lower CDR, can disrupt thyroid function in mammals (National Research Council, 2005), fish (Brown and others, 2004a; Patiño and others, 2003a), and amphibians (Goleman and others, 2002). In our study, TF presence, number, or size in carp were not related to an area with known perchlorate contamination (Lower CDR). However, further research is needed to determine the function of TFs in the head and hind kidney of carp and TF occurrence in carp but not bass or channel catfish. 


\section{Reproductive Biomarkers}

Reproductive biomarkers including gonadosomatic index (GSI), gonadal histopathology (for example, oocyte atresia and intersex condition), vitellogenin concentrations, and steroid hormone concentration were examined. These endpoints provide information on reproductive health of the fish and are quantifiable measures of biochemical, physiological, and histological changes that occur throughout the reproductive cycle. To minimize the effects of temperature, photoperiod, and annual reproductive cycle, all fish were collected postspawn within an eight week time period (August to October). Reproductive biomarkers can also be influenced by gender, maturational stage, age, and contaminants (Barry and others, 1990; Bromage and others, 1982; Chang and Chen, 1990; Denslow and others, 1999; Down and others, 1990; Goodbred and others, 1997; So and others, 1989). Reproductive biomarkers were tested using ANOVA models that contained the factors station (location), gender, gonadal stage, age, and their interactions (Appendix 6). Although gender was not a significant factor in all ANOVA models, females and males were analyzed separately because of the known gender influence on the reproductive biomarkers measured in this study. In this section, gonadal stage distribution, gonadal histopathology, GSI, vitellogenin concentrations, oocyte atresia (females only), and steroid hormone concentrations are described for each species and gender. Gonadal stage was a significant factor in many ANOVA models and is discussed where appropriate for each reproductive biomarker. Oocyte atresia data in fish from Stations 312, 315, 319, 320, and 324 were categorized and were not included in the statistical analyses or figures but are described where appropriate.

\section{Reproductive Biomarkers in Carp}

Gonadal stage in female carp was similar among CDRB stations. Most females (88\%) were stage 3, and the remaining fish were stage $0(1 \%), 1(1 \%)$, and 2 (10\%; fig. 20). A single stage-0 fish was from Station 315; stage-1 fish were found at Stations 320 and 324; and stage-2 fish were found at Stations $313,316,319,320,322$, and 323. Ovarian tissue from a single female carp from Station 320 contained primarily previtellogenic oocytes with a few spermatocytes, and this fish was considered to be intersex (fig. 21A).

In general, male carp were less advanced in gonadal stage than female carp from the same station (fig. 20). Most male carp were stage $2(46 \%)$ and $3(49 \%)$, and the remaining fish were stage $0(2 \%), 1(2 \%)$, and 4 (1\%; fig. 20). Stage- 0 and -1 fish were from Station 324 only, and the single stage-4 fish was from Station 323. Collection date did not explain the less advanced stage of fish from Station 324, because fish from Stations 323 and 325 were collected within several days of those from Station 324 (table 2).

GSI values in carp differed among stations $\left(F_{11,195}=\right.$ 2.20, $P<0.05)$ but not between genders $\left(F_{1,195}=2.48, P>\right.$
0.05). Station means ranged from $5.0 \%$ at Station 316 to $17.6 \%$ at Station 325 (table 24) and were $<10 \%$ at Stations $312,313,316,319,323$, and 324 (fig. 22). Proportionately larger ovaries were found in female carp from Stations 314, 317,321 , and 325 compared to those from most other stations. GSI values were $>20 \%$ only in female carp from Station 325 (fig. 22); these females were stage 3. The GSI values were lowest $(<2.0 \%)$ in female carp that were less advanced, stage- 0 female from Station $315(0.6 \%)$ and the stage-1 fish from Stations 320 and 324 (1.5\% and 2.0\%, respectively). One stage-2 fish from Station 323 was the only other female carp to have a GSI $<2.0 \%$. The GSI values in CDRB female carp were similar to those from previous LRMN and CDRB studies. Mean GSI values in female carp were $1-18 \%$ in the MRB (McDonald and others, 2002), 5-20\% in the RGB (Schmitt and others, 2004), 2-14\% (Hinck and others, 2004a), and 5-20\% in the Las Vegas Bay of Lake Mead (Patiño and others, 2003b).

GSI in male carp differed among CDRB stations. GSI data was not available for male carp from Station 317. Station means were lowest $(0.9 \%)$ at Station 324, and other means ranged from 3.6\% at Stations 320 and 325 to $9.6 \%$ at Station 321 (table 24). Proportionately smaller testes (GSI <1.0\%) were found in carp from Stations 320 and 324 compared to those from other stations (fig. 23), and these fish were in gonadal stages $0-4$. Histopathological analyses determined that most male carp with GSI values $<1.0 \%$ had poor testicular development with inflammation, calcified deposits, pigmented cell accumulations, and edema. Some of these observations have been previously associated with exposure to treated municipal sewage effluent in carp (Diniz and others, 2005; Lavado and others, 2004). The GSI values were $>12 \%$ in fish from Stations 314 and 321. In previous LRMN and CDRB studies, mean GSI values in male carp were approximately $2-12 \%$ in the MRB (McDonald and others, 2002), 1-13\% in the RGB (Schmitt and others, 2004), <0.1-11.0\% in the CRB (Hinck and others, 2004a), and 4-8\% in the Las Vegas Bay of Lake Mead (Patiño and others, 2003b).

Vitellogenin concentrations in carp differed among stations $\left(F_{12,199}=2.29, P<0.01\right)$ but not between genders $\left(F_{1,195}\right.$ $=0.60, P>0.05)$. Gender differences were likely not statistically significant as the result of the analytical model, which computes the $F$-statistic after accounting for all other factors (station, stage) in the model (Appendix 6). When stage was removed from the model, vtg concentrations differed between genders $\left(F_{1,223}=759.8, P<0.05\right)$. Concentrations of vtg were $1-10 \mathrm{mg} / \mathrm{mL}$ in most female carp (73\%), and station means ranged from $0.57 \mathrm{mg} / \mathrm{mL}$ at Station 324 to $5.95 \mathrm{mg} / \mathrm{mL}$ at Station 320 (table 24). Concentrations were low $(\leq 1.81 \mathrm{mg} / \mathrm{mL})$ in females from Station 324, most of which were stage-3 fish (figs. 20 \& 22). In addition to a stage-0 fish from Station 315 and a stage- 1 fish from Station 324, concentrations were $<0.1$ $\mathrm{mg} / \mathrm{mL}$ in stage- 2 and -3 females from Stations 316 and 325. Concentrations $>8 \mathrm{mg} / \mathrm{mL}$ were measured in fish from all stations except Station 324, and relatively high vtg concentrations $(>15 \mathrm{mg} / \mathrm{mL}$ ) were measured in females from Stations 316 and 320 (fig. 22). Concentrations in female carp were gener- 

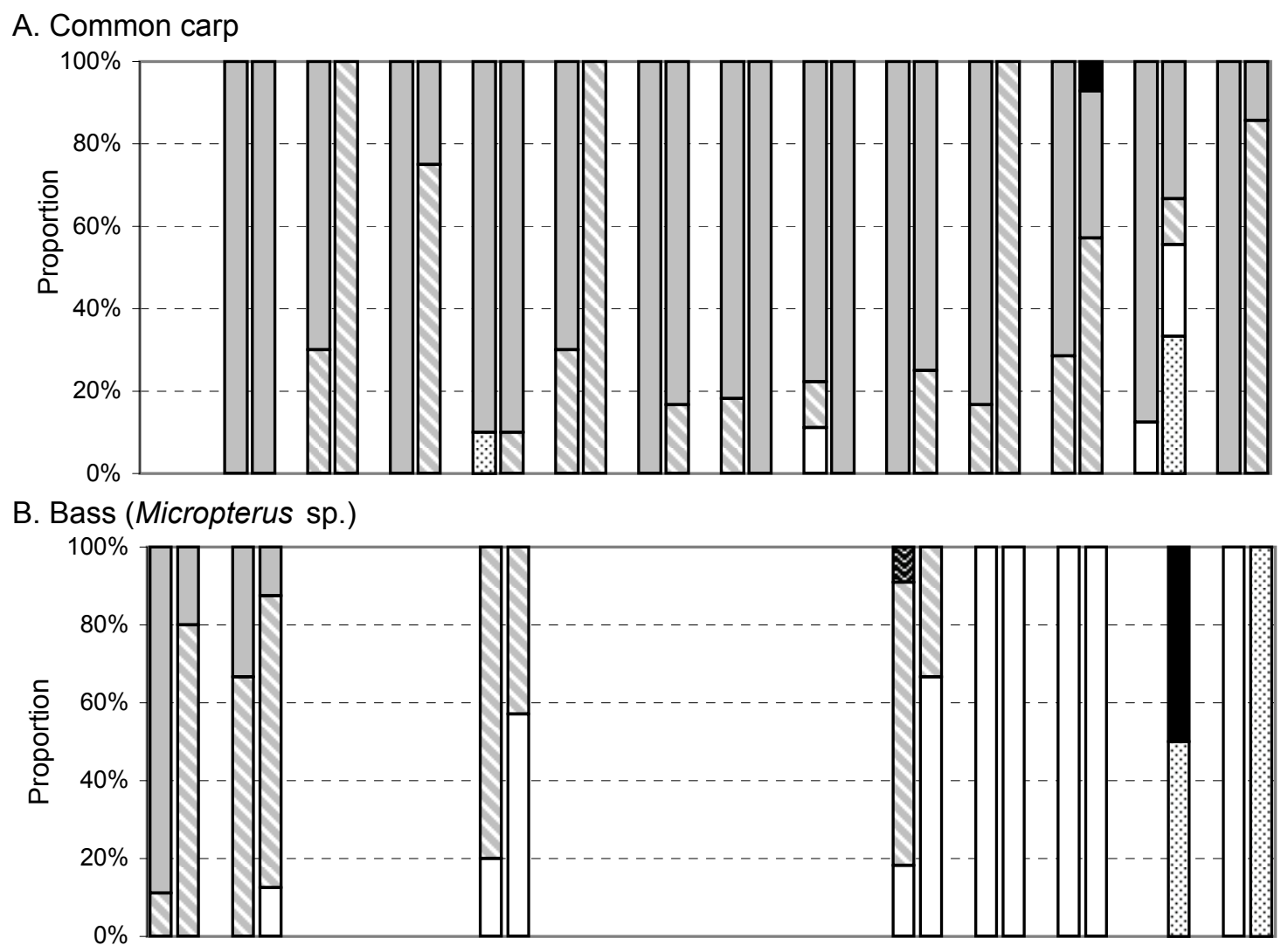

C. Channel catfish

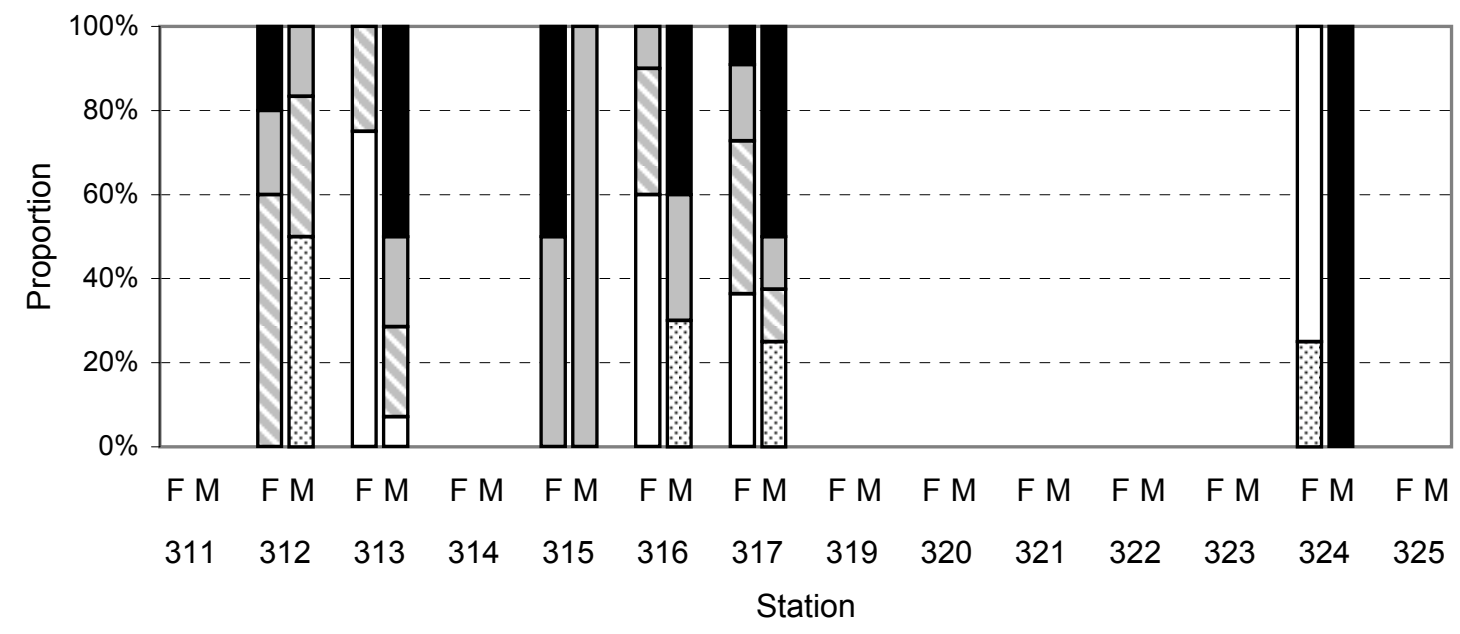

圆Stage $0 \square$ Stage $1 \square$ Stage $2 \square$ Stage $3 \square$ Stage 4 图Stage 5

Figure 20. Gonadal stage proportions by station in female (F) and male (M) carp (A), bass (B; Micropterus sp.), and channel catfish (C) from the Colorado River Basin in 2003. Stations are ordered from upstream to downstream. See Table 2 for station descriptions and collection dates.

ally greater than concentrations measured in previous LRMN investigations. Mean vtg concentrations in female carp were $\leq 2.9 \mathrm{mg} / \mathrm{mL}$ in the MRB (McDonald and others, 2002), $\leq 2.5$ $\mathrm{mg} / \mathrm{mL}$ in the RGB (Schmitt and others, 2004), and $\leq 3.9 \%$ $\mathrm{mg} / \mathrm{mL}$ in the CRB (Hinck and others, 2004a).
Vitellogenin concentrations were detected $(>0.0005 \mathrm{mg} /$ $\mathrm{mL}$ ) in male carp from all stations except Station 320 (fig. 23). Station means ranged from $<0.0005 \mathrm{mg} / \mathrm{mL}$ at Station 320 to $0.058 \mathrm{mg} / \mathrm{mL}$ at Station 322 and were generally greatest in fish from the GRB (table 24; fig. 23). Concentrations were $>0.01$ $\mathrm{mg} / \mathrm{mL}$ in $57 \%$ of male carp that were in stages $0-4$ (table 24 ). 

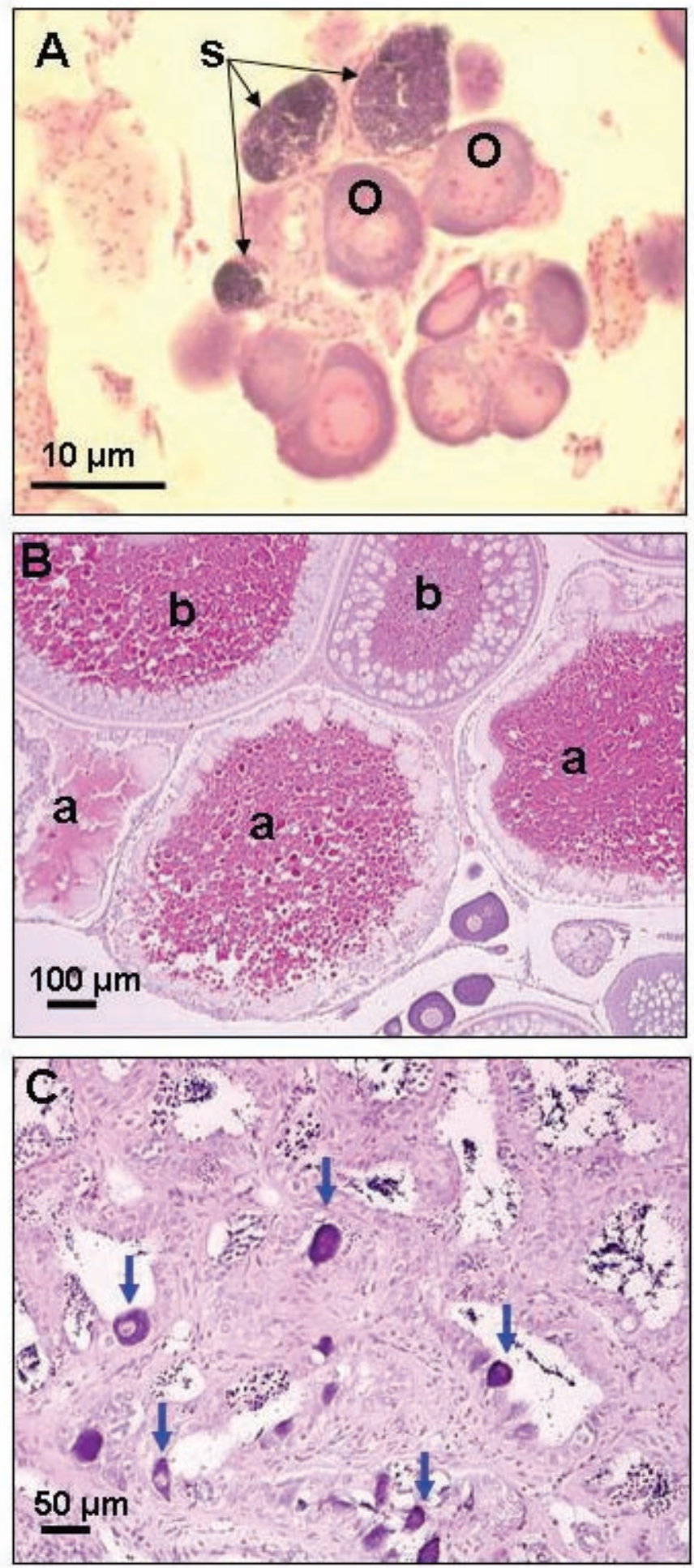

Figure 21. Selected gonadal histological observations in CDRB fish. A. Spermatocytes (s) and previtellogenic oocytes (o) in ovarian tissue of female carp from Willow Beach, Arizona (Station 320). B. High porportion of atretic oocytes (a) among healthyappearing oocytes (b) in carp from Delta, Colorado (Station 314). C. Intersex or the presence of previtellogenic oocytes (arrows) in testicular tissue of a male bass from Lay, Colorado (Station 311). Hematoxylin and eosin stain.
Relatively high concentrations in three males from Station $323(0.11-0.17 \mathrm{mg} / \mathrm{mL})$ and one male from Station $322(0.30$ $\mathrm{mg} / \mathrm{mL}$ ) may indicate an estrogenic response in these fish (fig. 23). Concentrations of vtg were more frequently detected in male CDRB carp compared those from previous LRMN investigations, but lower method LOD may be a factor in increased detection frequency. Most mean concentrations in male carp were near LOD $(0.001 \mathrm{mg} / \mathrm{mL})$ in the MRB (McDonald and others, 2002), RGB (Schmitt and others, 2004), and CRB (Hinck and others, 2004a), and vtg concentrations $>0.01 \mathrm{mg} /$ $\mathrm{mL}$ in male carp were rare in these studies.

An ANOVA model for oocyte atresia in female carp containing the factors station, age, gonadal stage, and their interactions was not significant $\left(F_{23,59}=1.62, P>0.05\right.$; Appendix 6). Station means ranged from $6.8 \%$ at Station 325 to $17.6 \%$ at Station 316 . Percent atresia was $<20 \%$ in most carp $(89 \%)$ but was $>25 \%$ in individual fish from Stations 313, 314, and 316 (fig. 21B). Percent oocyte atresia was also $<20 \%$ in most fish $(89 \%)$ from Stations 312, 315, 319, 320, and 324, where atresia data was categorized, but was $21-30 \%$ in fish from Stations $312(n=1), 319(n=3)$, and $324(n=1)$. In previous LRMN studies, mean percent atresia was approximately $0-25 \%$ in the MRB (McDonald and others, 2002), 1-13\% in the RGB (Schmitt and others, 2004), and 0-18\% in the CRB (Hinck and others, 2004a).

Concentrations of E2 differed among stations $\left(F_{12,206}\right.$ $=2.52, P<0.01)$ and between genders $\left(F_{1,206}=26.37, P<\right.$ $0.01)$, and KT concentrations differed between genders $\left(F_{1}\right.$, $\left.{ }_{206}=11.48, P<0.01\right)$ but not among stations $\left(F_{12,206}=1.38\right.$, $P>0.05)$. Both E2 and KT concentrations were generally greater in carp from the Upper CDRB than those from the Lower CDRB. Mean concentrations of E2 for females ranged from $275 \mathrm{pg} / \mathrm{mL}$ at Station 323 to $1,334 \mathrm{pg} / \mathrm{mL}$ at Station 314 (table 25). Mean E2 concentrations were $>1,200 \mathrm{pg} / \mathrm{mL}$ in females from Stations 313, 314, and 315 but were relatively low (400 pg/mL) in fish from Stations 323, 324, and 325 (fig. 22). These differences did not reflect stage differences among female carp. Mean E2 concentrations in female carp were slightly lower than those from the MRB (357-2,410 $\mathrm{pg} / \mathrm{mL}$; McDonald and others, 2002). Concentrations of KT in females were similar among CDRB stations, and KT concentrations were $100-500 \mathrm{pg} / \mathrm{mL}$ in most female carp (83\%). Station means for females ranged from $158 \mathrm{pg} / \mathrm{mL}$ at Station 323 to $473 \mathrm{pg} / \mathrm{mL}$ at Station 315 (table 25), and differences in KT concentrations did not reflect stage differences among female carp. Concentrations were $>600 \mathrm{pg} / \mathrm{mL}$ in fish from Stations $312,313,314,315$, and 321 (fig. 22). Mean KT concentrations in female carp from the MRB (109-987 pg/mL) were slightly greater than CDRB concentrations (McDonald and others, 2002). Concentrations of E2 were generally greater than KT concentrations in female carp as reflected by E/KT ratios $>1.0$ (fig. 22). The $\mathrm{E} / \mathrm{KT}$ ratios were $<1.0$ in individual fish from Stations 312, 320, 323, 324, and 325 (table 25). The E/KT ratio was 0.76 in the intersex carp from Station 320. The two lowest E/KT ratios (0.34 and 0.51) were in female carp from Station 325. 


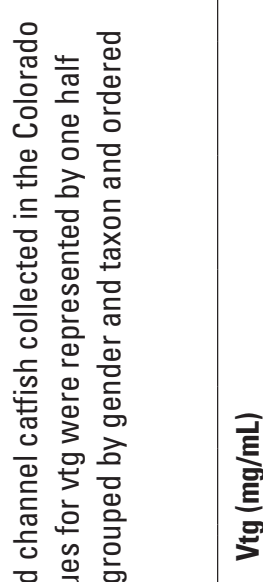

$\frac{0}{\Sigma}$

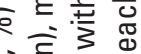

牙哭㐫

들

吾. 突

创 言 을

范势

空

음 응

듕 Ð

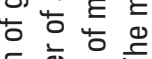

등 등

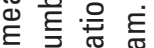

记艺要

छ

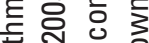

定.

员.

ปี ฮั

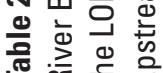

홍

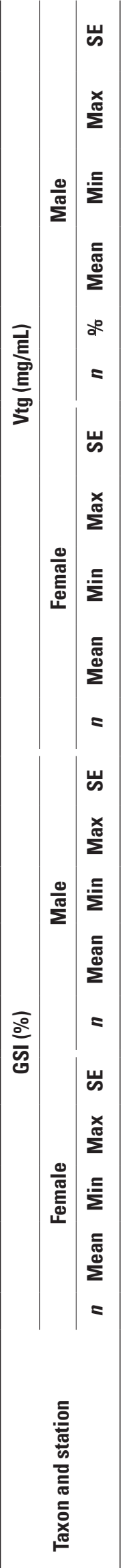

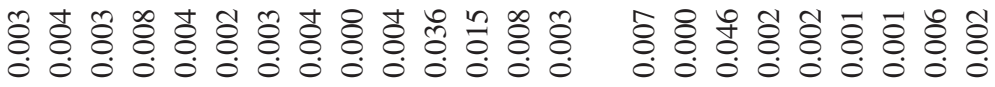

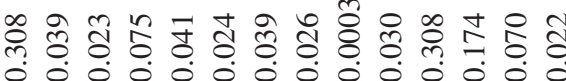

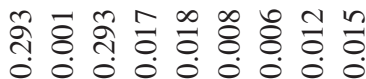

ชิ \&ิ

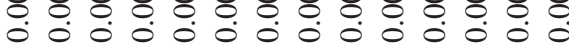

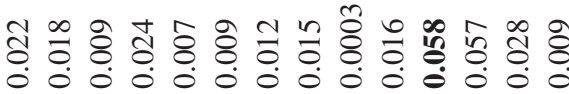

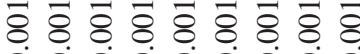

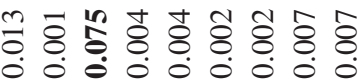

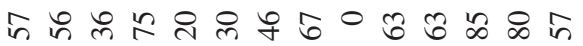

$\pm \circ \underset{m}{\infty} \pm=00$ in

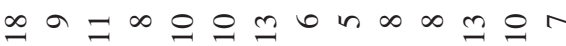

in $ᄋ \infty r a$ in $N \infty$

合合合合

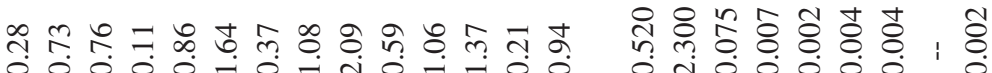

กี กิ

I

咅

व

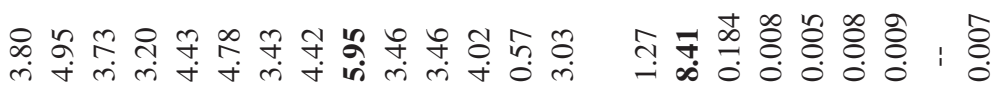

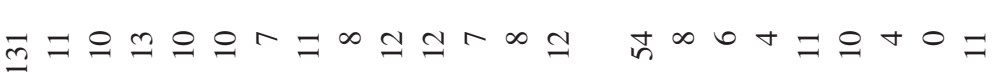

合合合合令

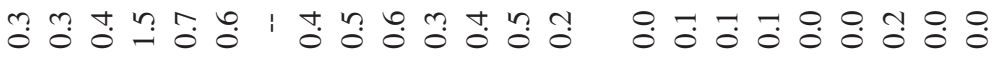

$\because \overrightarrow{0} \overrightarrow{0}: \overrightarrow{0} \overrightarrow{0}:$

岕

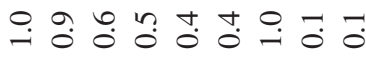

$\hat{0}+\dot{0} \tilde{0}:$ :

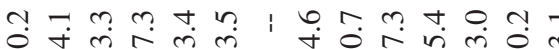

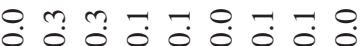

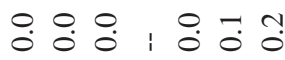

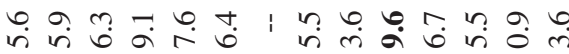

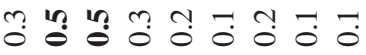

กิ่

ta $a n \circ a \circ b=\infty \infty \simeq$

in으 $\infty \times a n \times \infty$

ले $0-\infty \infty N$

サั่

ஜ்

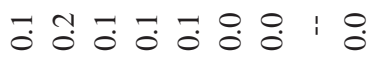

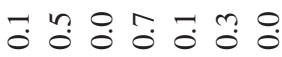

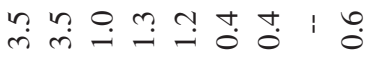

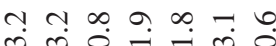

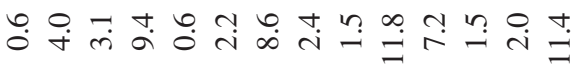

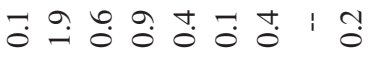

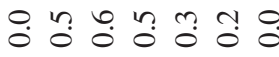

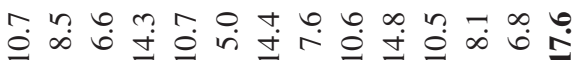

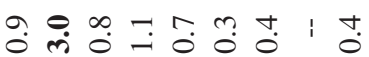

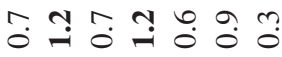

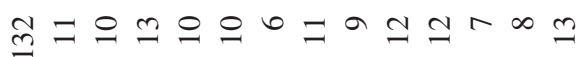

in $\circ$ ○ $=0+0=$

$\exists n+n O=\simeq$

을

तิ

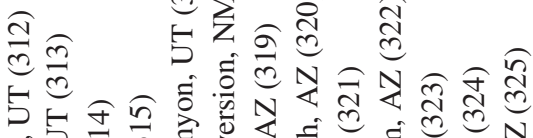

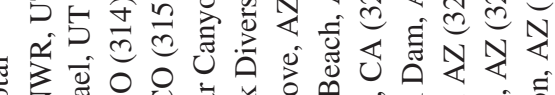

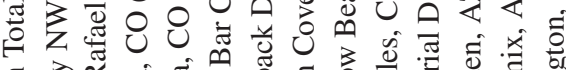

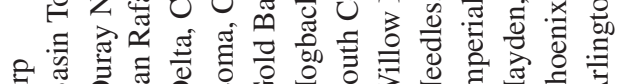




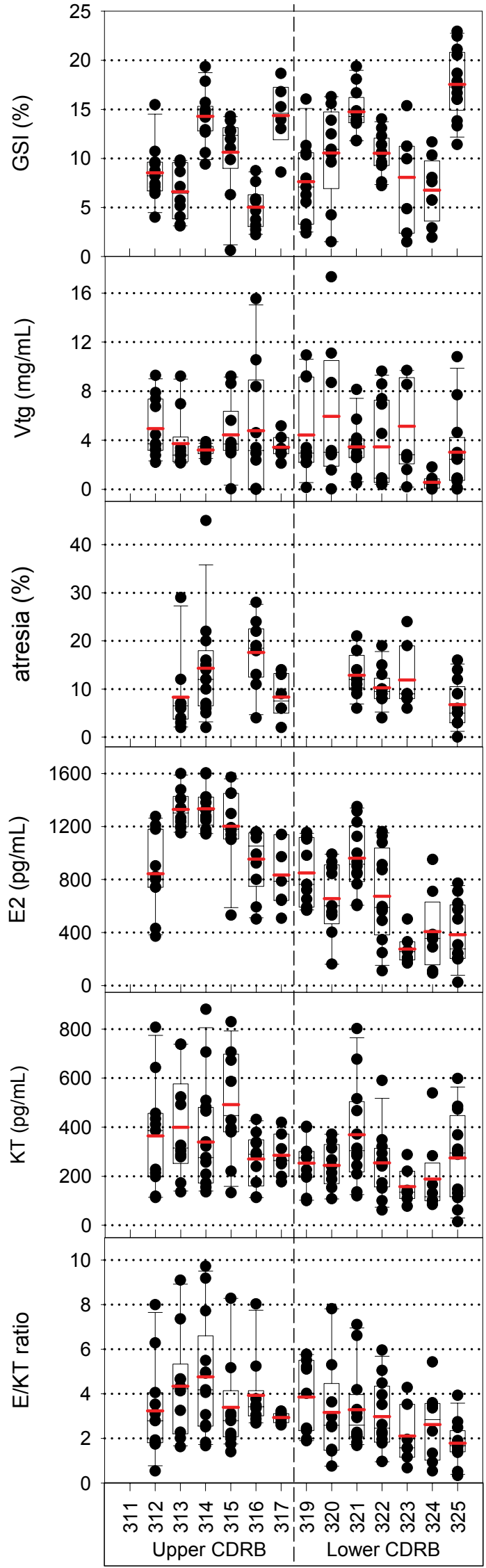

Station
E2 concentrations in most male carp (87\%) were 50-400 $\mathrm{pg} / \mathrm{mL}$. Station means ranged from $29 \mathrm{pg} / \mathrm{mL}$ at Station 319 to $313 \mathrm{pg} / \mathrm{mL}$ at Station 312 (table 25) and were $>200 \mathrm{pg} / \mathrm{mL}$ in males from Stations 312, 313, 314, and 315. Concentrations were uniformly low $(\leq 46 \mathrm{pg} / \mathrm{mL})$ in male carp from Station 319 (fig. 23), and these fish were stage-3 like most male carp from this study. Mean concentrations in male carp from the MRB (203-1,209 pg/mL) were greater than those from the CDRB (McDonald and others, 2002). Concentrations of KT were $100-1,100 \mathrm{pg} / \mathrm{mL}$ in most male CDRB carp (77\%), and station means ranged from $121 \mathrm{pg} / \mathrm{mL}$ at Station 319 to 1,141 $\mathrm{pg} / \mathrm{mL}$ at Station 312 (table 25). Concentrations were $>1,500$ $\mathrm{pg} / \mathrm{mL}$ in fish from Stations 312, 313, 315, 320, and 325 (fig. 23). Mean concentrations of KT in male carp from the MRB were 215-3,663 pg/mL (McDonald and others, 2002). Concentrations of KT were generally greater than E2 concentrations in male CDRB carp as reflected by E/KT ratios $<1.0$ (fig. 23). Ratios were $>1.0$ in fish from Stations 314, 316, 317, 321,323 , and 324 (table 25), and E/KT ratios were $>1.2$ in three fish from Station 316 (fig. 23).

\section{Reproductive Biomarkers in Bass}

Female bass were generally less advanced in gonadal stage than female carp at the same station (fig. 20). Bass from Stations 311 and 312 were exclusively smallmouth bass whereas bass from all other stations were largemouth bass. Most female bass were stage $1(50 \%)$, and the remaining fish were stage 2 (30\%), 3 (18\%), and 5 (2\%; fig. 20). Stage-2 fish were found at Stations 311, 312, 315, and 321, and stage-3 fish were at Stations 311 and 312. One fish from Station 321 was stage 1. In general, fish from Imperial Dam in the Lower CDR and the GR were less advanced (stage- 0 and - 1 ) than those from the Upper CDRB.

Male bass were generally less advanced in gonadal stage than male carp at the same station, but in similar stages as female bass. Most male bass were stage $1(44 \%)$ and $2(33 \%)$, and the remaining fish were stage 0 (16\%), 3 (5\%), and 4 (2\%; fig. 20). Similar to female bass, smallmouth bass from Stations 311 and 312 were more advanced (stage- 2 and - 3 ) and largemouth bass from Stations 322, 323, 324, and 325 were less advanced (stage-0 and -1). Most male bass from Stations 324 and 325 were stage 0 (immature), and the stage- 4 (spent) male bass was from Station 324. Intersex gonads were found

Figure 22. Reproductive health indicators by station in female carp from the Colorado River Basin in 2003. Indicators include gonadosomatic index (GSI), vitellogenin (vtg), atresia, 17 $\beta$ estradiol (E2), 11-ketotestosterone (KT), and the ratio of estradiol and II-ketotestosterone (E/KT). Shown for each group are points representing individual fish and the mean (red horizontal line), median (black horizontal line), interquartile range (box), and the 10th and 90th percentiles (whiskers). Stations are ordered from upstream to downstream and are grouped by sub-basin. See Table 2 for station descriptions. 


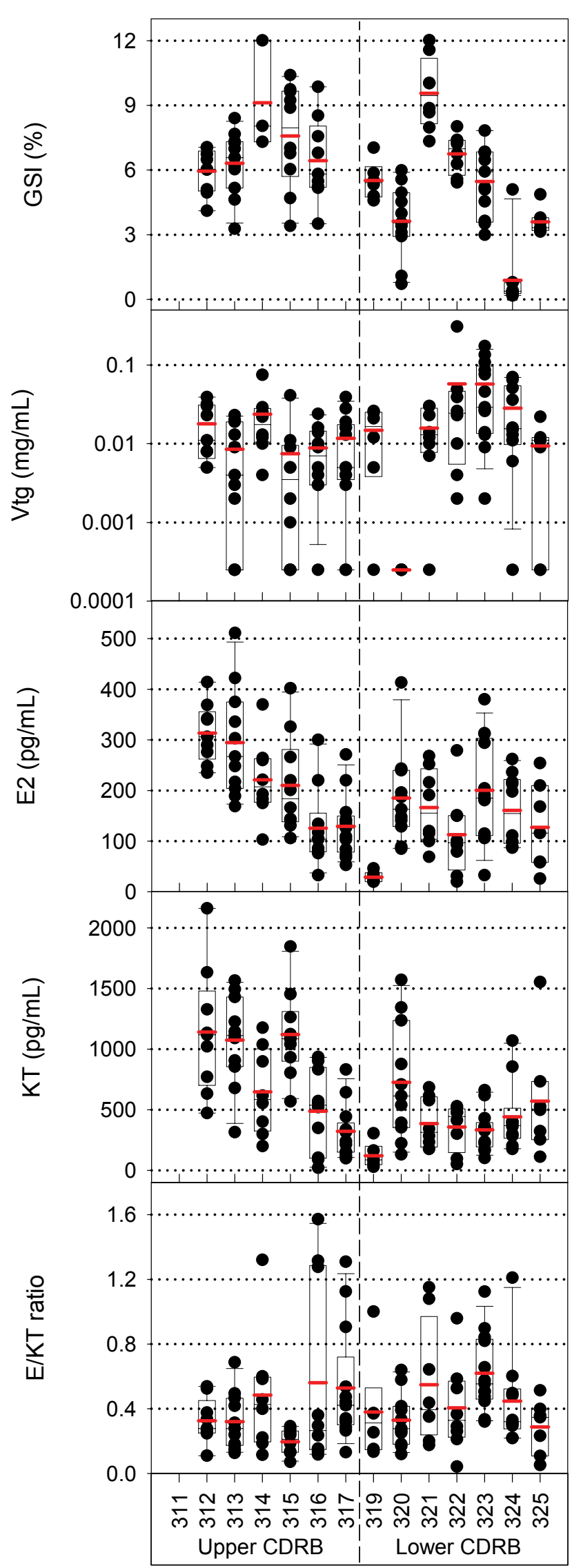

Station in male bass from Stations 311, 322, and 323. A relatively high proportion of male bass from Station 311 were intersex. Mild to moderate numbers of oocytes in testicular tissue were found in seven of ten male smallmouth bass from Station 311 (fig. 21C). Mild occurrence of oocytes in testicular tissue was identified in four of ten largemouth bass from Station 322 and two of five largemouth bass from Station 323. All intersex largemouth bass were stage 1 , but intersex smallmouth bass (Station 311) were stage 2 and 3.

GSI values in bass differed among stations $\left(F_{5,91}=5.91, P\right.$ $<0.01)$ and between genders $\left(F_{1,91}=14.60, P<0.01\right)$. Lower GSI values were calculated for females from the Lower CDRB than those from the Upper CDRB. Station means ranged from $0.3 \%$ at Station 322 to $3.0 \%$ at Station 311 and were $>1.0 \%$ at Stations 311 and 315 (table 24). The GSI values were greater in female smallmouth bass from Station 311 (1.9-3.5\%) than females from other stations (fig. 24). Most female bass from Station 311 were stage 3, but GSI values were $<1.0 \%$ in stage3 fish collected from Station 312. The greater GSI values in the bass may reflect the later collection from Station 311 (table 2 ). The GSI values were $<0.6 \%$ in female bass from Stations 322,323 , and 325 (table 24), which reflected the less advanced stage (stage-1) of these fish (fig. 20). Mean GSI values were $<2 \%$ in the MRB (McDonald and others, 2002), 0.6-0.9\% in the RGB (Schmitt and others, 2004), and 0.5-2.9\% in the CRB (Hinck and others, 2004a).

GSI values in male bass were generally low $(<1.0 \%)$. The GSI values were generally greater in more advanced (stage-2 and -3) male bass from the Upper CDRB than in less advanced (stage-0 and -1) fish from the Lower CDRB. Station means ranged from $0.1 \%$ to $0.5 \%$ (table 24 ), and GSI values were $>0.6 \%$ in fish from Stations 311, 312, and 323 (fig. 25). Mean GSI values in male bass were approximately $0.1-0.7 \%$ in the MRB (McDonald and others, 2002), 0.2-0.4\% in the RGB (Schmitt and others, 2004), and 0.2-0.9\% in the CRB (Hinck and others, 2004a).

Vitellogenin concentrations in bass did not differ among stations $\left(F_{5,89}=1.73, P>0.05\right)$ or between genders $\left(F_{1,89}=\right.$ $1.75, P>0.05)$. However, concentrations of vtg were greater in female smallmouth bass from Station 311 than those from other stations (fig. 24). Station means ranged from 0.005 $\mathrm{mg} / \mathrm{mL}$ at Station 321 to $8.4 \mathrm{mg} / \mathrm{mL}$ at Station 311 (table 24). Concentrations were $>5.0 \mathrm{mg} / \mathrm{mL}$ in multiple females from Station 311 but were $<0.37 \mathrm{mg} / \mathrm{mL}$ in all other female bass

Figure 23. Reproductive health indicators by station in male carp from the Colorado River Basin in 2003. Indicators include gonadosomatic index (GSI), vitellogenin (vtg), 17ß-estradiol (E2), 11-ketotestosterone (KT), and the ratio of estradiol and II-ketotestosterone (E/KT). Shown for each group are points representing individual fish and the mean (red horizontal line), median (black horizontal line), interquartile range (box), and the 10th and 90th percentiles (whiskers). Stations are ordered from upstream to downstream and are grouped by sub-basin. See Table 2 for station descriptions. 


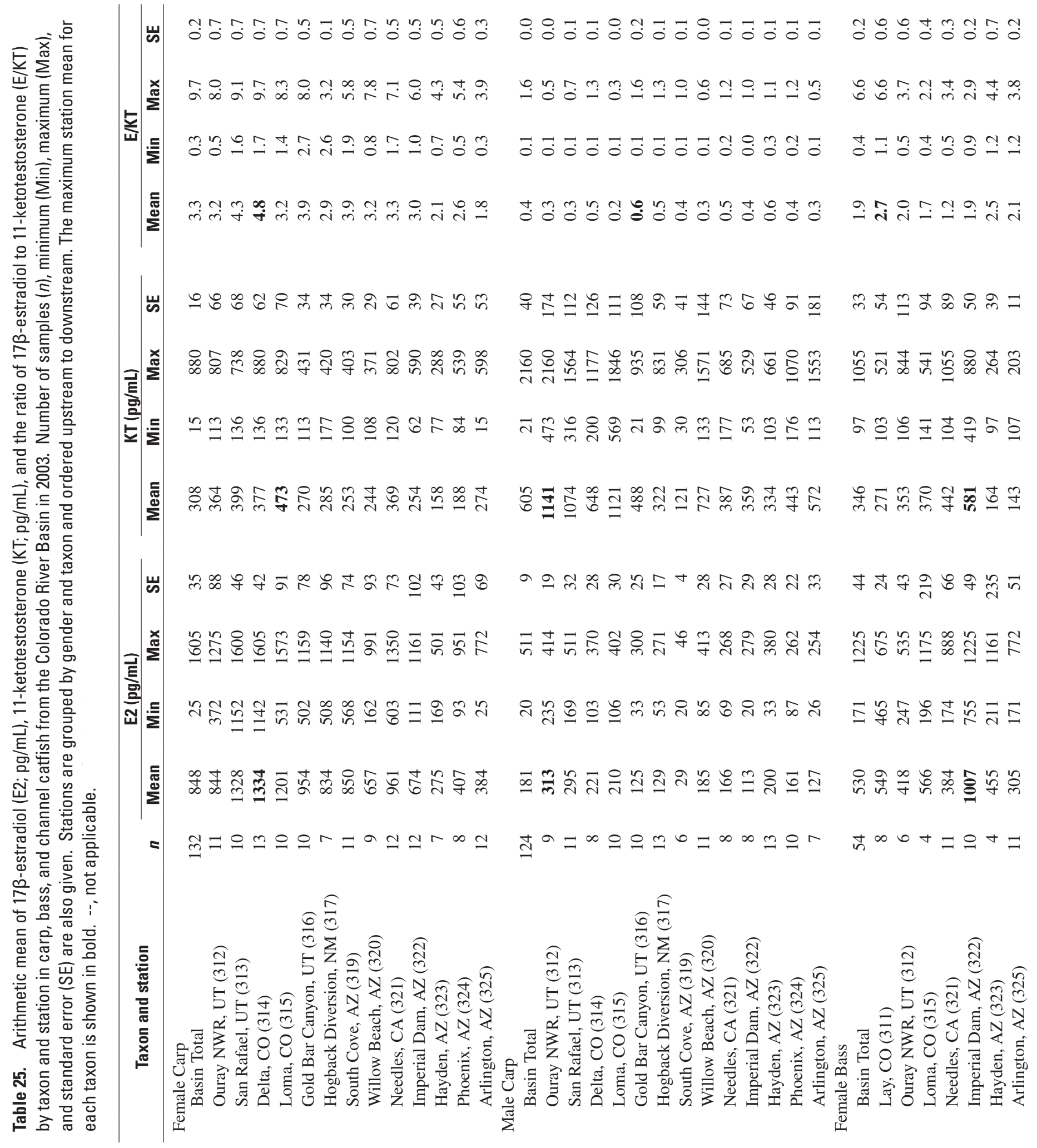




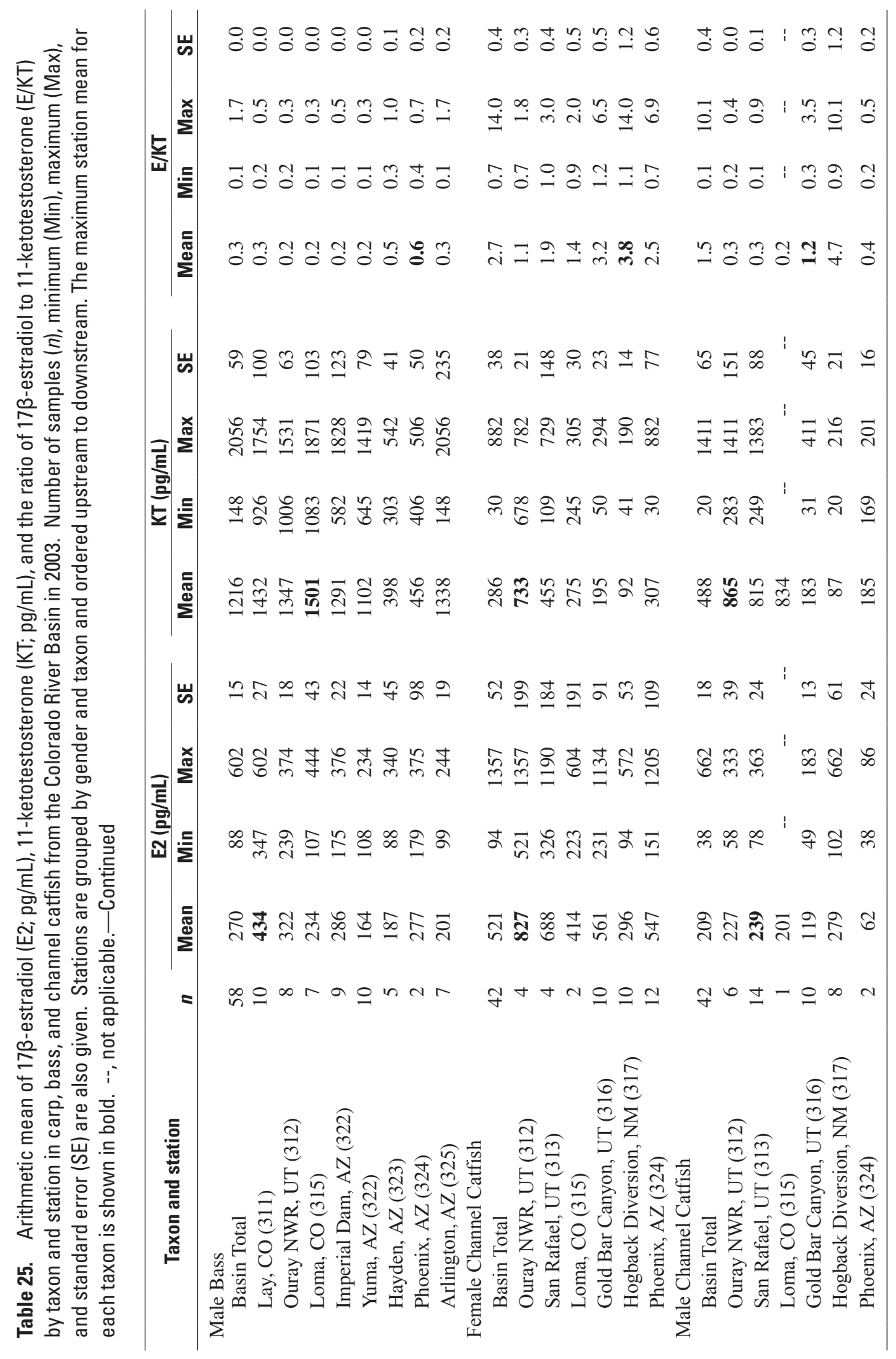




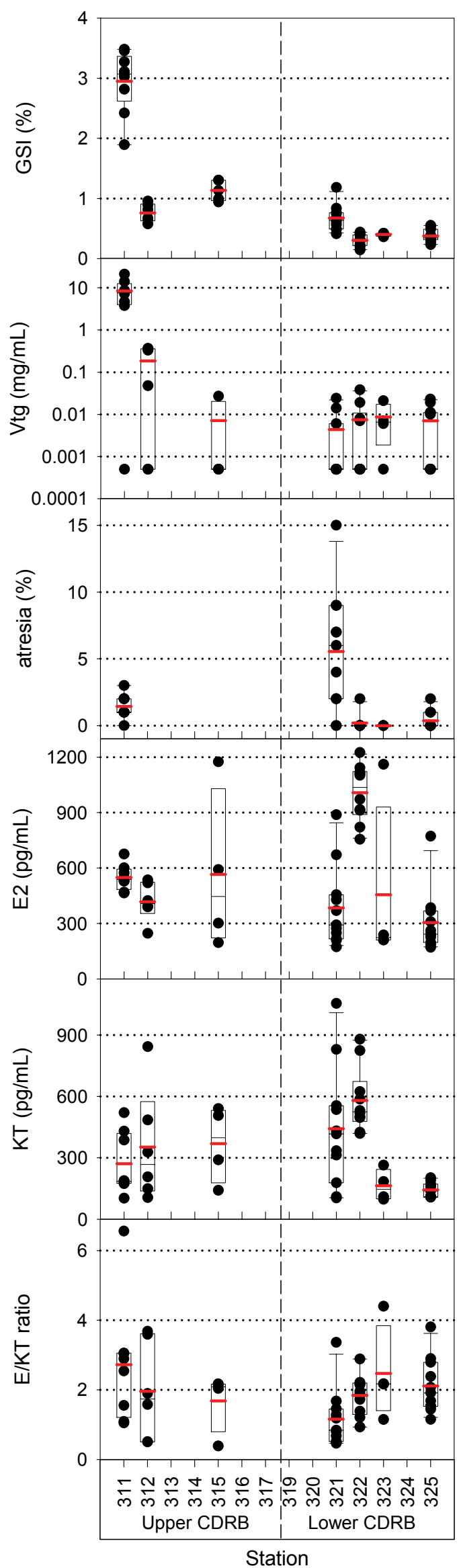

(table 24; fig. 24). The greatest vtg concentrations (>0.3 mg/ $\mathrm{mL}$ ) were in the more advanced stage (most stage-3) fish from Stations 311 and 312. The mean vtg concentration in female bass from Station 311 was among the greatest measured in any LRMN investigation. Mean vtg concentrations in female bass were $\leq 3.7 \mathrm{mg} / \mathrm{mL}$ in the MRB (McDonald and others, 2002), $0.01-3.1 \mathrm{mg} / \mathrm{mL}$ in the RGB (Schmitt and others, 2004), and 0.06-14.3 $\mathrm{mg} / \mathrm{mL}$ in the CRB (Hinck and others, 2004a).

Vitellogenin concentrations were detected $(>0.001$ $\mathrm{mg} / \mathrm{mL}$ ) in male bass from all stations except Station 311 (fig. 24). Concentrations of vtg were $\leq 0.02 \mathrm{mg} / \mathrm{mL}$ in most $(97 \%)$ males, and station means ranged from $<0.001 \mathrm{mg} / \mathrm{mL}$ at Station 311 to $0.075 \mathrm{mg} / \mathrm{mL}$ at Station 312 (table 24). Males from Station 311 were generally in more advanced stages (stages 2 and 3 ) than those from other stations, and seven of 10 male bass from Station 311 were intersex. Concentrations were relatively high $(\geq 0.28 \mathrm{mg} / \mathrm{mL})$ in two stage- 2 males from Station 312 and may indicate an estrogenic response in these two fish. These concentrations are similar to those reported in male bass from the MRB (McDonald and others, 2002), RGB (Schmitt and others, 2004), and CRB (Hinck and others, 2004a), but vtg concentrations $>0.1 \mathrm{mg} / \mathrm{mL}$ in male bass were rare in these previous studies.

Oocyte atresia in female bass differed among gonadal stage $\left(F_{1,31}=15.84, P<0.01\right)$ and was generally lower in female bass $(<5 \%)$ than in carp $(>10 \%)$. Station means ranged from $0.0 \%$ at Station 323 to $5.5 \%$ at Station 321 (fig. 24). Percent atresia was $<5 \%$ in bass from all stations except Station 321 , where oocyte atresia was $>5 \%$ in six fish. Oocyte atresia was generally greater in stage- 2 fish $(>4 \%)$ than those in other gonadal stages $(<2 \%)$. Percent oocyte atresia was also $<10 \%$ in fish from Stations 312 and 315 where atresia data was categorized. Percent atresia was generally less in CDRB bass than those from previous LRMN studies. Mean percent atresia in bass was approximately $0-6 \%$ in the MRB (McDonald and others, 2002), 0-30\% in the RGB (Schmitt and others, 2004), and $1-12 \%$ in the CRB (Hinck and others, 2004a).

Concentrations of E2 in bass did not differ among stations $\left(F_{5,88}=0.34, P>0.05\right)$, gonadal stage $\left(F_{1,88}=0.08, P\right.$ $>0.05)$, or between genders $\left(F_{1,88}=0.36, P>0.05\right)$. KT concentrations differed among stations $\left(F_{5,88}=2.24, P<0.05\right)$ and between genders $\left(F_{1,88}=8.08, P<0.01\right)$ but not among gonadal stage $\left(F_{1,88}=1.85, P>0.05\right)$. Most E2 concentrations $(89 \%)$ in female bass were $200-1,200 \mathrm{pg} / \mathrm{mL}$, and station

Figure 24. Reproductive health indicators by station in female bass (Micropterus sp.) from the Colorado River Basin in 2003. Indicators include gonadosomatic index (GSI), vitellogenin (vtg), atresia, 17ß-estradiol (E2), 11-ketotestosterone (KT), and the ratio of estradiol and II-ketotestosterone (E/KT). Shown for each group are points representing individual fish and the mean (red horizontal line), median (black horizontal line), interquartile range (box), and the 10th and 90th percentiles (whiskers). Stations are ordered from upstream to downstream and are grouped by subbasin. See Table 2 for station descriptions. 


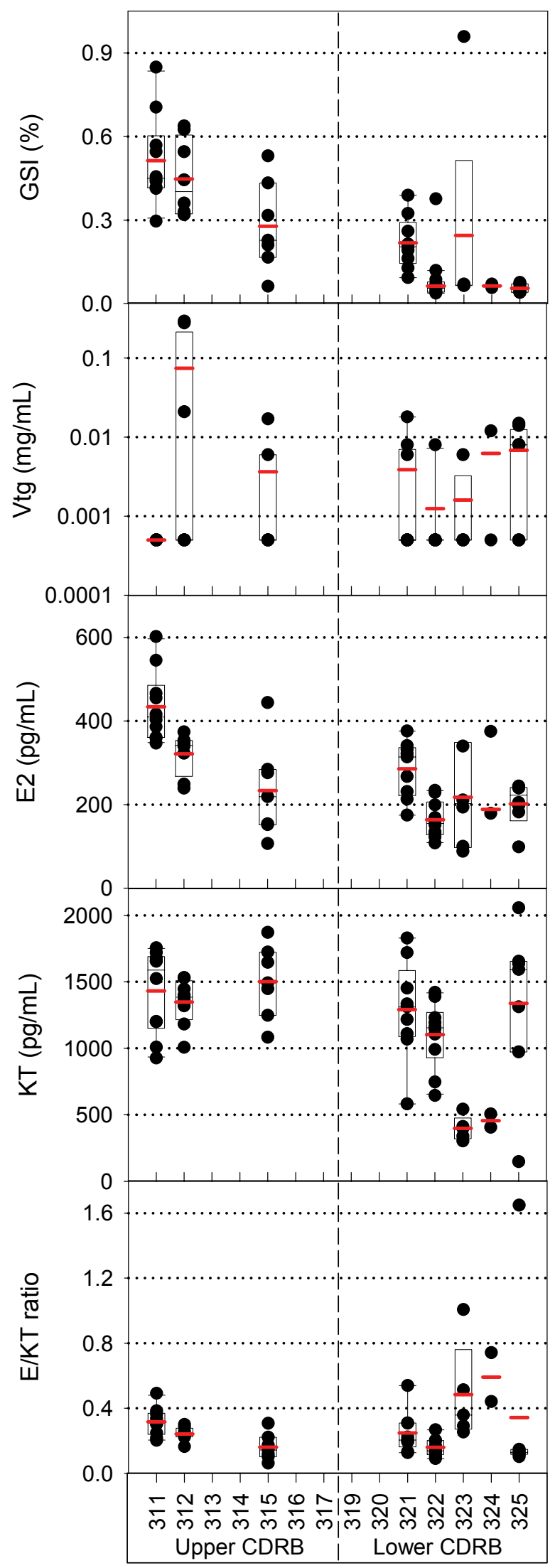

Station means ranged from $305 \mathrm{pg} / \mathrm{mL}$ at Station 325 to $1,007 \mathrm{pg} / \mathrm{mL}$ at Station 322 (table 25). Concentrations were relatively high $(>900 \mathrm{pg} / \mathrm{mL})$ in females from Station 322 (fig. 24). Concentrations of KT were $100-625 \mathrm{pg} / \mathrm{mL}$ in most female bass (89\%). Station means ranged from $143 \mathrm{pg} / \mathrm{mL}$ at Station 325 to $581 \mathrm{pg} / \mathrm{mL}$ at Station 322 (table 25). KT concentrations in females were greatest at Station 322 and were relatively low $(<300 \mathrm{pg} / \mathrm{mL})$ at Stations 323 and 325 (fig. 24). Mean concentrations of $\mathrm{E} 2$ and $\mathrm{KT}$ in female bass from the MRB were $238-1,726 \mathrm{pg} / \mathrm{mL}$ and $62-1,019 \mathrm{pg} / \mathrm{mL}$, respectively (McDonald and others, 2002). Concentrations of E2 were generally greater than $\mathrm{KT}$ concentrations in female bass as reflected by E/KT ratios $>1.0$ (fig. 24). Ratios $<1.0$ were reported in females from Stations 312, 315, 321, and 322 (table 25; fig. 24), and ratios were $<1.0$ in six female bass from Station 321 due to low E2 concentrations $(\leq 300 \mathrm{pg} / \mathrm{mL})$ in these fish.

Most E2 concentrations (90\%) were $100-450 \mathrm{pg} / \mathrm{mL}$ in male bass, and station means ranged from $164 \mathrm{pg} / \mathrm{mL}$ at Station 322 to $434 \mathrm{pg} / \mathrm{mL}$ at Station 311 (table 25). Relatively low concentrations $(\leq 100 \mathrm{pg} / \mathrm{mL})$ were measured in males from Stations 323 and 325 (fig. 25); GSI values and vtg concentrations were also low in these male bass. Concentrations of E2 were generally greatest $(>350 \mathrm{pg} / \mathrm{mL})$ in males from Station 311, which was the only station where vtg concentrations were not detected in male bass. Concentrations of E2 were relatively high (340-602 pg/mL) in intersex male smallmouth bass from Station 311 but were lower (108-324 $\mathrm{pg} / \mathrm{mL}$ ) in intersex male largemouth bass from Stations 322 and 323. However, bass from the Lower CDRB were less advanced in their gonadal stage, which may explain the lower sex steroid hormone concentrations in these fish (fig. 20). The KT concentrations were $400-1,800 \mathrm{pg} / \mathrm{mL}$ in most male bass (88\%), and station means ranged from $398 \mathrm{pg} / \mathrm{mL}$ at Station 323 to $1,501 \mathrm{pg} / \mathrm{mL}$ at Station 315 (table 25). Concentrations of KT were much lower in male bass from Stations 323 and 324 than all other stations (fig. 25) and were not related to gonadal stage. Mean concentrations of E2 and KT were 201$855 \mathrm{pg} / \mathrm{mL}$ and $167-2,502 \mathrm{pg} / \mathrm{mL}$, respectively, in male bass from the MRB (McDonald and others, 2002). The E/KT ratio was generally $<1.0$ in male bass (fig. 25), and ratios were $>1.0$ in only two fish from Stations 323 and 325 (table 25).

Figure 25. Reproductive health indicators by station in male bass (Micropterus sp.) from the Colorado River Basin in 2003. Indicators include gonadosomatic index (GSI), vitellogenin (vtg), 17ß-estradiol (E2), 11-ketotestosterone (KT), and the ratio of estradiol and II-ketotestosterone (E/KT). Shown for each group are points representing individual fish and the mean (red horizontal line), median (black horizontal line), interquartile range (box), and the 10th and 90th percentiles (whiskers). Stations are ordered from upstream to downstream and are grouped by subbasin. See Table 2 for station descriptions. 


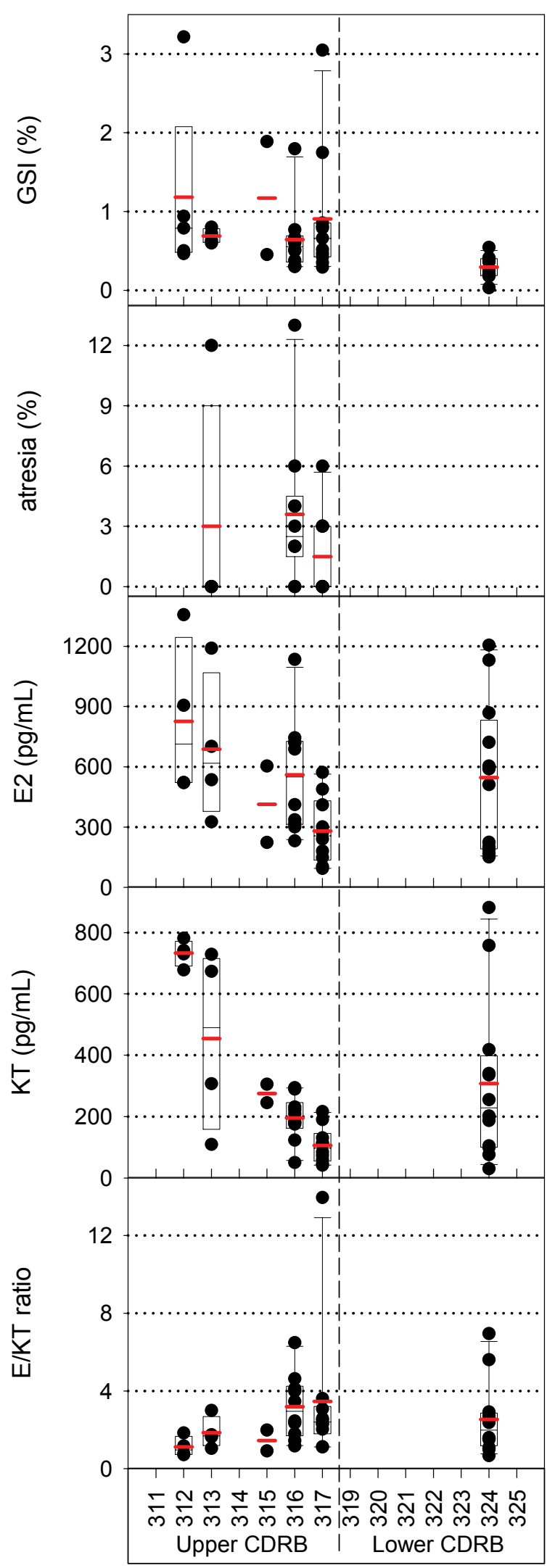

Station

\section{Reproductive Biomarkers in Channel catfish}

Gonadal stage was more variable in female channel catfish than in female carp or bass at the same stations. Most fish were stage $1(48 \%)$, and the remaining were stage $0(7 \%)$, $2(25 \%), 3$ (11\%), and 4 (9\%; fig. 20). Stage-0 (immature) females were found at Station 324 only. Stage-1 fish were from Stations 313, 316, 317, and 324, and stage-2 females were from Stations 312, 313, and 317. Female channel catfish identified as stage-3 were from Stations 312, 315, 316, and 317 , and stage- 4 females were from Stations 312,315 , and 317.

Similar to female channel catfish, gonadal stage was more variable in male channel catfish than in male carp or bass from the same station. Most male channel catfish were stage $4(43 \%)$ and $3(21 \%)$, and the remaining males were stage 0 $(17 \%), 1(2 \%)$, and 2 (17\%; fig. 20). Stage-0 males were from Stations 312, 316, and 317. The one stage- 1 fish was from Station 313, and stage-2 fish were from Stations 312, 313, and 317. Males identified as stage- 3 were from Stations 312, 313, 315,316 , and 317, and stage-4 males were from Stations 313, 316, 317, and 324. All male channel catfish from Station 324 $(n=3)$ were spent (stage-4). Intersex gonads were observed in a relatively small proportion of male channel catfish from Stations 312, 317, and 324. One male fish from each of these stations had evidence of ovotestes. Intersex males from Stations 312 and 317 were stage 0 , but the intersex male channel catfish from Station 324 was stage 4.

GSI values differed among stations $\left(F_{6,60}=4.34, P<\right.$ $0.01)$, gonadal stage $\left(F_{1,60}=22.37, P<0.01\right)$, and between genders $\left(F_{1,60}=5.05, P<0.05\right)$. Most GSI values were $<3.0 \%$, and station means ranged from $0.3 \%$ at Station 324 to $1.2 \%$ at Stations 312 and 315 in female channel catfish (table 24). Relatively low GSI values $(<0.4 \%)$ were calculated for most females from Station 324 (fig. 26), and all of these females were stage 0 and 1 . Fish with GSI values $>1.0 \%$ were in advanced reproductive stages (stage 3 or 4), although these stages were also observed in females with GSI values $<0.8 \%$. In male channel catfish, station means for GSI values ranged from $0.2 \%$ to $0.4 \%$ (table 24 ; fig. 27). Values $<0.1 \%$ were only observed in stage- $0,-1$, and -4 males, and GSI values were generally greater in stage- 2 and -3 males. These GSI values are similar to those in female (0.6-2.3\%) and male (0.02-0.10\%) channel catfish from the RGB (BEST-LRMN Program, unpublished data).

Figure 26. Reproductive health indicators by station in female channel catfish from the Colorado River Basin in 2003. Indicators include gonadosomatic index (GSI), vitellogenin (vtg), atresia, 17ß-estradiol (E2), 11-ketotestosterone (KT), and the ratio of estradiol and II-ketotestosterone (E/KT). Shown for each group are points representing individual fish and the mean (red horizontal line), median (black horizontal line), interquartile range (box), and the 10th and 90th percentiles (whiskers). Stations are ordered from upstream to downstream and are grouped by subbasin. See Table 2 for station descriptions. 


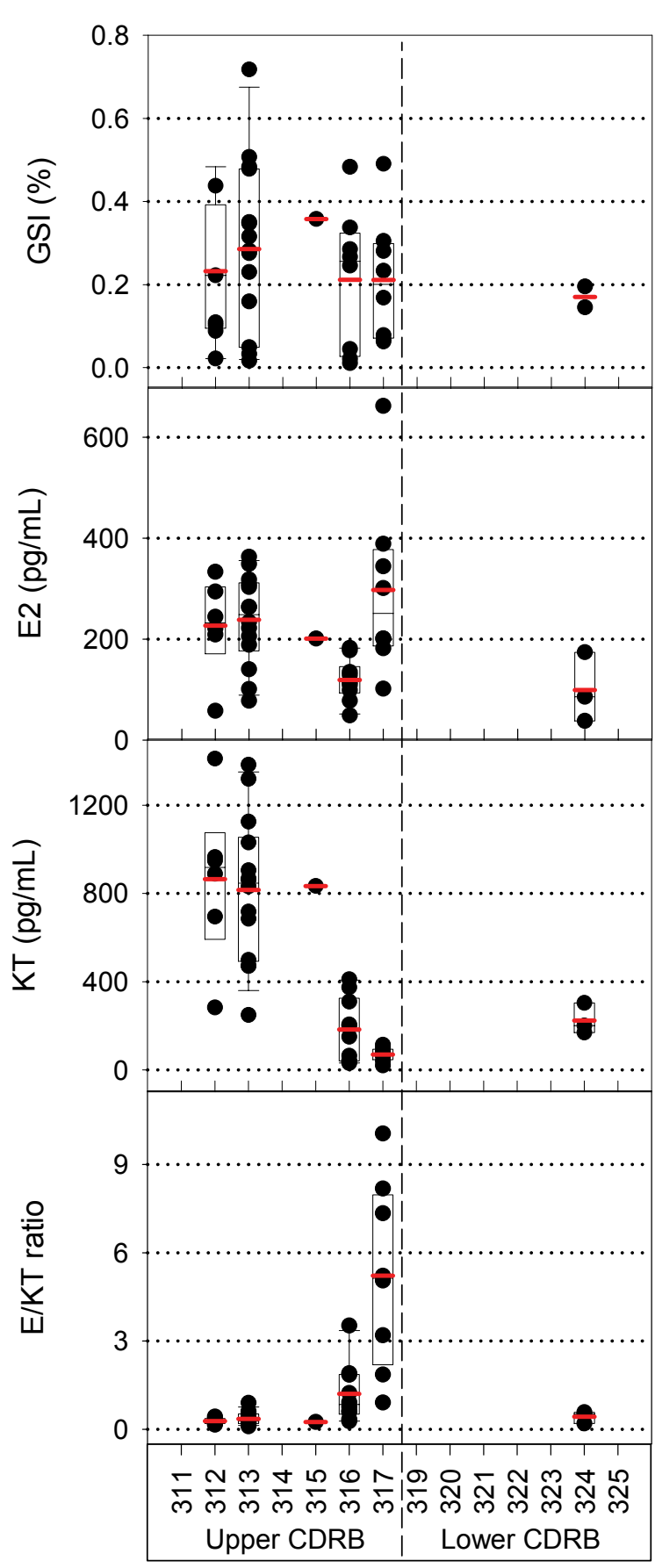

Station

Figure 27. Reproductive health indicators by station in male channel catfish from the Colorado River Basin in 2003. Indicators include gonadosomatic index (GSI), vitellogenin (vtg), 17ß-estradiol (E2), 11-ketotestosterone $(\mathrm{KT})$, and the ratio of estradiol and II-ketotestosterone $(\mathrm{E} / \mathrm{KT})$. Shown for each group are points representing individual fish and the mean (red horizontal line), median (black horizontal line), interquartile range (box), and the 10th and 90th percentiles (whiskers). Stations are ordered from upstream to downstream and are grouped by subbasin. See Table 2 for station descriptions.
An ANOVA model for oocyte atresia in female channel catfish containing the factors station, age, gonadal stage, and their interactions was not significant $\left(F_{10,13}=1.53, P>0.05\right.$; Appendix 6). Oocyte atresia was $\leq 6 \%$ in most female channel catfish (fig. 26) and was not related to gonadal stage. Oocyte atresia in females was similar among stations; station means ranged from $1.5 \%$ at Station 317 to $3.6 \%$ at Station 316. In addition, oocyte atresia was $<10 \%$ in fish from Stations 312 and 324 where the data were categorized. Other studies measuring atretic eggs in channel catfish were not found.

E2 concentrations in channel catfish did not differ among stations $\left(F_{5,61}=0.64, P>0.05\right)$, gonadal stage $\left(F_{1,61}=1.13\right.$, $P>0.05)$, or between genders $\left(F_{1,61}=1.10, P>0.05\right)$. KT concentrations differed among stations $\left(F_{5,61}=3.52, P<0.01\right)$ and between genders $\left(F_{1,61}=5.19, P<0.05\right)$ but not among gonadal stage $\left(F_{1,61}=0.06, P>0.05\right)$. Most E2 concentrations $(83 \%)$ in female channel catfish were $100-900 \mathrm{pg} / \mathrm{mL}$ (table 25), and station means ranged from $296 \mathrm{pg} / \mathrm{mL}$ at Station 317 to $827 \mathrm{pg} / \mathrm{mL}$ at Station 312. Concentrations were relatively low $(<200 \mathrm{pg} / \mathrm{mL})$ in individual females from Stations 317 and 324 (fig. 26). The KT concentrations were $50-420 \mathrm{pg} / \mathrm{mL}$ in most female channel catfish (74\%). Station means ranged from $92 \mathrm{pg} / \mathrm{mL}$ at Station 317 to $733 \mathrm{pg} / \mathrm{mL}$ at Station 312 (table 25). Concentrations were uniformly high $(>650 \mathrm{pg} / \mathrm{mL})$ in females from Station 312 and low $(<305 \mathrm{pg} / \mathrm{mL})$ in those from Stations 315, 316, and 317 (fig. 26). Few E/KT ratios were $<1.0$ in female channel catfish. However, ratios $>5.0$ were observed in fish from Stations 316, 317, and 324 as a result of low KT concentrations in these males (fig. 26).

In male channel catfish, most E2 concentrations (86\%) were $80-400 \mathrm{pg} / \mathrm{mL}$ (table 25), and station means ranged from $62 \mathrm{pg} / \mathrm{mL}$ at Station 324 to $239 \mathrm{pg} / \mathrm{mL}$ at Station 313. Concentrations were relatively low $(<200 \mathrm{pg} / \mathrm{mL})$ in fish from Stations 316 and 324 (fig. 27). Most (76\%) KT concentrations were $60-1,000 \mathrm{pg} / \mathrm{mL}$ in male channel catfish, and station means ranged from $87 \mathrm{pg} / \mathrm{mL}$ at Station 317 to $865 \mathrm{pg} / \mathrm{mL}$ at Station 312 (table 25). Concentrations were uniformly low $(<400 \mathrm{pg} / \mathrm{mL})$ in males from Stations 316, 317, and 324 (fig. 27). The E/KT ratio was $>5.0$ in several males from Station 317 as a result of low KT concentrations $(<81 \mathrm{pg} / \mathrm{mL})$ in these fish (fig. 27), and low KT concentrations were also measured in female channel catfish from this station. Steroid hormone concentrations in channel catfish from other studies were not found.

\section{Reproductive Biomarkers: Summary}

The reproductive biomarkers used in this study are the key measures of reproductive function and are routinely used to help evaluate contaminant effects or simply assess general reproductive health in fish. Age, species, water temperature, photoperiod, and other biotic and abiotic factors can influence these biomarkers over the course of the reproductive cycle. Therefore, care must be taken when interpreting these reproductive biomarkers and these ancillary factors considered when possible. Our evaluations consider the age, species, 
and gonadal stage directly; while photoperiod and temperature may be considered through indirect information about each station (collection date and available gauging station information, respectively). All fish samples were collected post-spawn and within an eight week time period (August to October) to minimize the variation of reproductive biomarkers from temperature, photoperiod, and annual reproductive cycle. However, natural changes or fluctuations in reproductive biomarkers may have occurred during this collection period.

The GSI is often used to evaluate reproductive status and health, although interpretations of GSI values rely on understanding natural variations among fish of similar age, gender, and species. Environmental influences and behavioral patterns may also confound the interpretation of the data. Considerable variations in gonad size have been reported throughout the reproductive cycle of most species of fish (de Vlaming and others, 1981). The gonads can constitute substantially differing proportions of the total body weight of a fish (that is, GSI). For example, gonads made up a greater proportion of the total body mass in carp than in bass or channel catfish in this study. Proportionately larger gonads were found in female carp from Stations 314, 317, 321, and 325, male carp from Stations 314 and 321, female bass from Station 311, and relatively small gonads were identified in male carp from Stations 320, 324, and 325, female and male bass from Stations 322, 323, and 325, and female channel catfish from Station 324. Attempts were made to minimize the differences in gonad size due to collection period by collection the fish post-spawn and within an eight week time period. Most GSI values corresponded with gonadal stage (that is, GSI values increased as gonadal stage advanced). Abnormally low GSI values were measured in multiple male carp from Station 324. Exposure to wastewater effluent has been correlated with decrease GSI values in fish (Diniz and others, 2005; Gross and others, 2004; Lavado and others, 2004). Patiño and others (2003b) reported that GSI values in male carp from Las Vegas Bay were consistently lower $(<7.5 \%)$ than males from the Overton Arm of Lake Mead regardless of season and suggested that environmental contaminants such as PCBs, dioxins, furans, and PBDEs may be affecting the reproductive development in male carp. However, reproductive development was not impaired in female carp from Las Vegas Bay (Patiño and others, 2003b).

Gonadal histopathology was used to confirm gender, assign reproductive stage, and detect anatomical abnormalities such as the presence of ovotestes and excessive oocyte atresia. Collection date did not appear to affect gonadal stage. Carp were in similar stages of gonadal maturity except for male carp from Station 324, which were less advanced (stage-0 and -1) and had low GSI values. These differences were not related to age or size of carp from this station. In bass, most females and males in the Lower CDRB were less advanced than those from the Upper CDRB. Gonadal stage was variable in channel catfish.

Oocyte atresia is defined as the involution or resorption of oocytes by the ovaries and has been validated as a histopathological biomarker. Although oocyte atresia is a normal physi- ological event in all fish, it can become a pathological condition following exposure to certain environmental contaminants (Cross and Hose, 1988, 1989; Johnson and others, 1988; Kirubagaran and Joy, 1988). Other factors such as water temperature can also influence pathological oocyte atresia (June, 1970, 1977). Oocyte atresia $\geq 25 \%$ in female carp and $>10 \%$ in female bass were defined as high in a previous LRMN study (McDonald and others, 2002). Atresia was low in most CDRB fish, but individual fish with relatively high atresia were noted in carp from Stations 313, 314, 316, and 319 and bass from Station 321.

Intersex was identified in carp, bass, and channel catfish from seven of 14 CDRB stations. Evidence of ovotestes was found in seven of ten male smallmouth bass from Station 311, four of ten largemouth bass from Station 322, two of five largemouth bass from Station 323, and one of eight carp from Station 320. Stations 312, 317, and 324 each had one male channel catfish with ovotestes. Gonadal tissue of all intersex bass and channel catfish was primarily testicular tissue with an apparent invasion of mild to moderate amounts of ovarian follicles or oocytes. In contrast, the intersex carp collected at Station 320 had gonads which contained mainly ovarian tissue with some spermatocytes. During field necropsy of this female carp, the gonads were described as dark red lax tissue with pouches of clear fluid; other females from this site appeared normal with gonads full of eggs. A thin abdominal wall and fluid-filled body cavity were also noted for the intersex female carp during the field examination. This is the first occurrence of intersex carp and channel catfish in the BESTLRMN Program. Previous LRMN studies have only observed ovotestes in bass, which have been predominantly found to contain small numbers of oocytes in otherwise normal testicular tissue (Hinck and others, 2004a; McDonald and others, 2002; Schmitt and others, 2004). To our knowledge, the background occurrence of intersex fish has not been established for any of these species, but the high proportion of intersex smallmouth bass from Station 311 (70\%) is cause for concern. Ovotestes were not found in any male smallmouth bass from Station 312, located several hundred kilometers downstream of Station 311 in the Upper CDRB. These results indicate that the fish from Station 311 may have had an estrogenic response although the cause is unknown and warrants further investigation. Other reproductive biomarkers in bass from Station 311 were anomalous. Station 311 was the only station where vtg concentrations were not detected in male bass, but concentrations in female bass were the greatest measured $(>5.0 \mathrm{mg} / \mathrm{mL})$ in $\mathrm{CDRB}$ fish. Concentrations of E2 were also relatively high $(>300 \mathrm{pg} / \mathrm{mL})$ in all male smallmouth bass (including intersex bass) from Station 311; high E2 concentrations in these fish could be a result of these fish being in advanced gonadal stages (stage 2) and later collection date (late October).

Vitellogenin concentrations were measured in carp and bass but not in channel catfish. In female bass, concentrations were $>5 \mathrm{mg} / \mathrm{mL}$ in smallmouth bass from Station 311 but $<0.37 \mathrm{mg} / \mathrm{mL}$ in smallmouth bass from other stations. Concentrations were relatively low $(<1.8 \mathrm{mg} / \mathrm{mL})$ in stage- 2 
female carp from Station 324. Other biomarkers were normal in carp from this station, but high concentrations of organochlorines have been reported historically in this area. Vitellogenin was detected in male carp and bass from most CDRB stations, but concentrations were $<$ LOD in all males from Station 320. Concentrations were $>0.1 \mathrm{mg} / \mathrm{mL}$ in male carp from Stations 322 and 323 and male bass from Station 312 and may indicate that these fish have been exposed to estrogen mimics. Some organochlorine pesticides can act like estrogen mimics, but concentrations of the organochlorine pesticides measured in this study were low in male fish from Stations 312,322 , and 323. Other estrogen mimics including nonylphenol and ethynylestradiol may affect vtg concentrations in male fish but were not measured in this study. Previous studies have localized vtg receptors to the testes, muscle, and spermatocytes (Bidwell and Carlson, 1995; Tao and others, 1996), but the function and importance of these receptors in male fish are unknown. Detectable concentrations of vtg have been documented in male fish as a result of lower assay LODs, but concentrations $>0.001 \mathrm{mg} / \mathrm{mL}$ are generally considered anomalous in male fish.

Like many other reproductive biomarkers, concentrations of sex steroid hormones can vary by gender, age, geographical locations, species, and season (Barry and others, 1990; Bromage and others, 1982; Chang and Chen, 1990; Denslow and others, 1999; Down and others, 1990; Goodbred and others, 1997; So and others, 1989). Variation in sex steroid hormones concentrations within each species is expected (McDonald and others, 2002), but E/KT ratios $>1.0$ in females and $<1.0$ in males are generally considered normal (Folmar and others, 1996; Hileman, 1994).

Sex steroid hormone concentrations differed by species, station, and gender in CDRB fish. Steroid hormone concentrations in carp were generally greatest in fish from the Upper CDRB. Relatively low E2 and KT concentrations were measured in females from Station 323, 324, and 325 and males from Station 319. Gross and others (2004) also reported that $\mathrm{KT}$ concentrations were low in male fish from Las Vegas Bay of Lake Mead and suggested that wastewater effluent may be affecting reproductive biomarkers in the fish. Concentrations of KT were also relatively low in male bass from Stations 323 and 324. In contrast, steroid hormone concentrations in female bass were greater at Station 322 than those from other stations, and E2 concentrations were greatest in male bass from Station 311, which included seven intersex fish. Concentrations of KT in female channel catfish were relatively high at Station 312 and low at Stations 315, 316, and 317; E/KT ratios were $>5.0$ in multiple female catfish from Station 316 . In male channel catfish, E2 and KT concentrations were low in fish from Stations 316 and 324. The KT concentrations were low and E2 concentrations were high in male channel catfish from Station 317, resulting in E/KT ratios >5 in many fish.

\section{Spatial patterns in contaminant concentrations and biomarker responses}

\section{Correlations between Chemical and Biological Endpoints}

Spearman Rank correlations were examined to determine if chemical concentrations were related to biomarker responses in the CDRB (table 26). Significant correlations $(P<0.05)$ were determined for each gender and species. Few biomarker responses were found to be correlated with contaminants and present in more than one species, gender, or both (table 26). Interpretation of these data may be limited by the range of contaminant concentrations and sample sizes.

\section{Geographic Summaries}

Geographic station summaries were made to emphasize relatively high contaminant concentrations, consistent biomarker responses, or both (table 27). The highlighted findings indicate contaminant concentrations or EROD activities that exceeded known thresholds or were outside expected ranges relative to other CDRB stations. The colors for the fish health indicators and reproductive biomarkers are relative and indicate the number, magnitude, or both of the anomalies at a station. The summaries are intended to draw attention to particular stations discussed in the text, possibly for further investigation. Increased frequencies of external lesions or elevated HAI scores, which represent the cumulative total number of grossly visible internal and external lesions, do not necessarily indicate direct contaminant effects. Many factors other than contaminants can indirectly influence fish health indicators and reproductive biomarkers, including nutrients, organic matter, and water temperature. Considerably more is known about risk to fish and piscivorous wildlife associated with bioaccumulative contaminants and EROD activities than about long- and short-term risks represented by the other biomarkers. Therefore, greater relative risk has been associated with elevated contaminant concentrations and EROD activities than with anomalous fish health indicators or reproductive biomarkers (table 27).

\section{Upper Colorado River Basin (Upper CDRB)}

The Upper CDRB includes Station 311 on the Yampa River, Stations 312 and 313 on the Green River, Station 314 on the Gunnison River, Stations 315 and 316 on the CDR, and Station 317 on the San Juan River. Carp and bass or channel catfish were the target species, but white suckers (Station 311) and brown trout (Station 314) were collected when target species were not found. Certain areas in the Upper Colorado including NWRs near Station 311 and 312 provide important nesting sites for large populations of ducks and geese and resting and feeding areas for migratory birds. Certain 


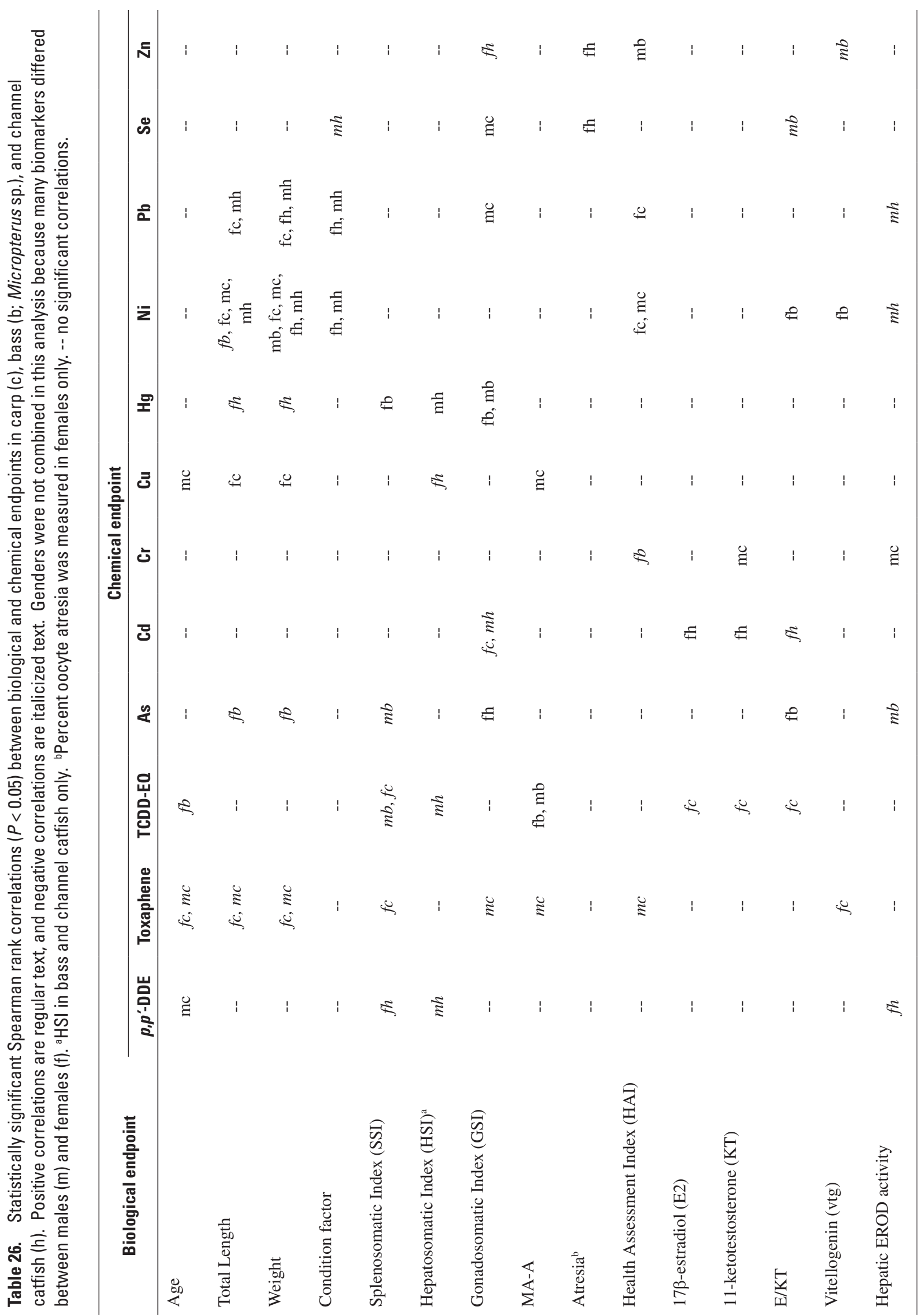




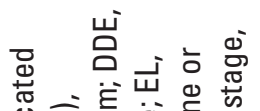

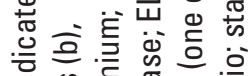
.

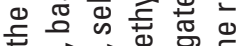

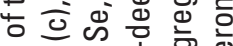

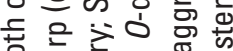

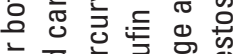

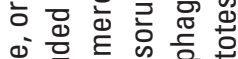
造

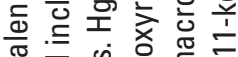
む)

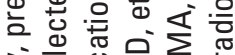

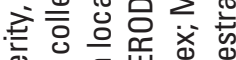
dै.

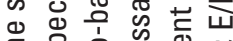
की 劳 导 음 क

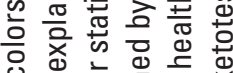

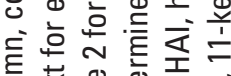

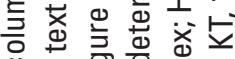

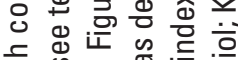
등

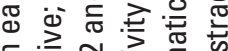

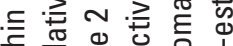

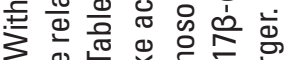

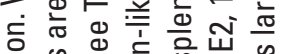

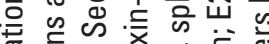

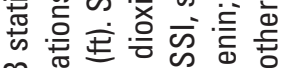

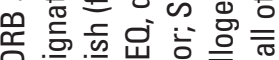

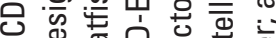
วิ

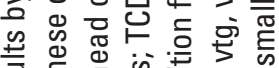

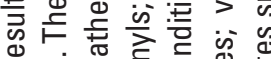
ఏ) 흔 은 든 는 언 응 언

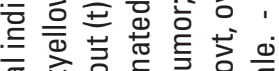

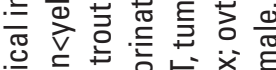

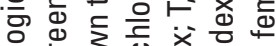

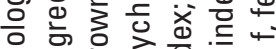
느드으으음 듬 ส

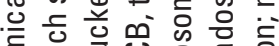

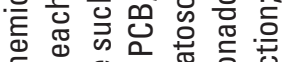

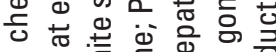

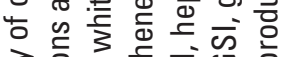
증으음

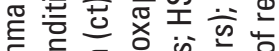

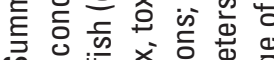

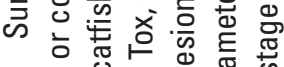
人

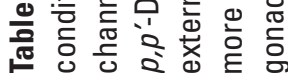

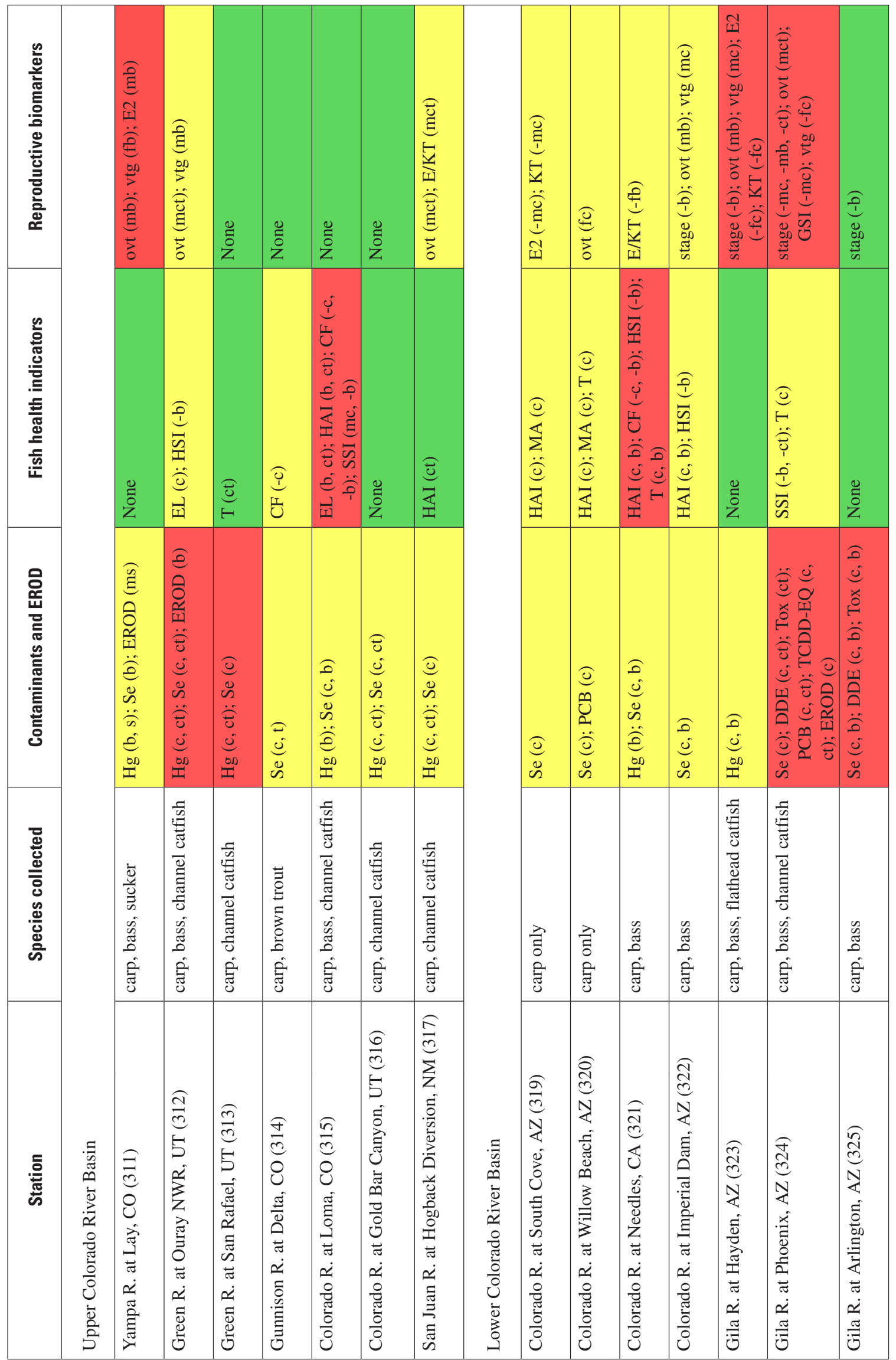


piscivorous species including the bald eagle (Haliaeetus leucocephalus) overwinter in the Upper CDRB at Ouray NWR (Station 312) and western Colorado (Station 315). Chemical contaminants can enter the waters of the Upper CDRB through a variety of basin activities and processes. Mining activities have introduced heavy metals including $\mathrm{Cd}, \mathrm{Cu}, \mathrm{Pb}$, and $\mathrm{Zn}$ and degraded water quality in many Upper CDRB rivers and streams (CDPHE, 1998; UDEQ, 2000). Major commercial deposits of oil shale, tar sands, and coal are located in the Upper Green River Basin. Irrigation canals transport Se leached from the underlying shales and have contaminated many Upper CDRB waters that have resulted in multiple fish consumption advisories in rivers and reservoirs (USEPA, 2004a). Mercury advisories for sport fish in reservoirs of the San Juan River and Dolores River Basins are potentially from mining and atmospheric deposition from coal-fired power plants (Abell, 1994; Melancon and others, 1979). Colorado's largest coal-fired power plants located along the Yampa River near Craig have high $\mathrm{Hg}$ emissions and acid deposition, which has been linked to reproductive impairments in amphibians in north central Colorado (Turk and Campbell, 1997).

\section{Yampa River, Lay, CO (Station 311)}

Station 311 was located on the Yampa River near Lay, Colorado. Smallmouth bass and white sucker were collected in late October 2003. Several contaminants and biomarkers exceeded threshold criteria or appeared anomalous in fish (table 27). Selenium concentrations were $>0.75 \mu \mathrm{g} / \mathrm{g}$ in all samples and $>1.0 \mu \mathrm{g} / \mathrm{g}$ in female smallmouth bass (fig. 28); these concentrations are potentially hazardous to fish and piscivorous wildlife (Lemly, 1996). Mercury concentrations ranged from $0.18 \mu \mathrm{g} / \mathrm{g}$ to $0.27 \mu \mathrm{g} / \mathrm{g}$ and were among the greatest measured in this study (fig. 28). Mercury concentrations $>0.1 \mu \mathrm{g} / \mathrm{g}$ may be harmful to piscivorous mammals (Yeardley and others, 1998). Seven of 10 male bass from Station 311 were intersex (fig. 29), which is one of the greatest percentages of intersex fish found at a site by the BEST-LRMN Program. Hepatic EROD activity was relatively high ( $>25$ pmol. $\mathrm{min} / \mathrm{mg}$ ) in male white sucker. Altered sex ratios have been documented in the offspring of fish with whole-body $\mathrm{Hg}$ concentrations of 0.44-1.1 $\mu \mathrm{g} / \mathrm{g}$ (Matta and others, 2001), but it is unknown whether the relatively high $\mathrm{Hg}$ concentrations and intersex condition in male bass from Station 311 were related. The estrogenic effects of metals and metal mixtures (for example, Le Guével and others, 2000) are largely unknown but should be considered when interpreting reproductive biomarkers. Concentrations of E2 were elevated in all male bass $(>400$ $\mathrm{pg} / \mathrm{mL}$ ) from this station as compared to other stations, yet vtg concentrations in these same fish were within normal ranges. Relatively high sex steroid hormone concentrations and low vtg concentrations can occur when circulating steroid hormones are bound to steroid hormone binding proteins in the plasma and are not free to enter into target tissues such as the liver (Tollefsen, 2002). Further investigations are required to determine whether these concentrations are a result of contam- inant exposure. GSI values were normal in the intersex fish, which is consistent with the lack of induction of vtg found in males from this station. Concentrations of vtg in female bass from Station 311 were also greater than observed at other stations, and the mean vtg concentration in female bass $(8.4$ $\mathrm{mg} / \mathrm{mL}$ ) was among the greatest measured in bass from any LRMN investigation. Station 311 was sampled last (late October) in our study (table 2); this later collection may partially explain the higher vtg concentrations. Overall, reproductive biomarkers were anomalous at this site. The high incidence of intersex smallmouth bass has rarely been documented at this magnitude in previous studies. Facilities commonly associated with estrogenic contaminants (for example, wastewater treatment plants) are not located near Station 311, but water from the Yampa River is diverted near Station 311 to irrigate fields of alfalfa or grass hay along the river (R. Krueger, written communication). Further research is needed to determine the cause of intersex fish in the Yampa River.

\section{Green River, Ouray NWR, UT (Station 312)}

Station 312 was located in the Ouray NWR along the Green River in Utah, an area known for its historical Se contamination. Carp, smallmouth bass, and channel catfish were collected in September 2003. Several elemental contaminants and biomarkers exceeded threshold criteria or appeared anomalous in fish (table 27). Selenium concentrations were $>0.9$ $\mu \mathrm{g} / \mathrm{g}$ in channel catfish and $>1.4 \mu \mathrm{g} / \mathrm{g}$ in carp (fig. 28); these concentrations are potentially harmful to fish and piscivorous wildlife (Lemly, 1996). Mercury concentrations exceeded $0.1 \mu \mathrm{g} / \mathrm{g}$, which may be hazardous to piscivorous mammals (fig. 28; Yeardley and others, 1998). Hepatic EROD activities in female and male bass were uniformly greater at Station 312 compared to other CDRB stations but were generally lower than those from previous LRMN investigations (Hinck and others, 2004a; Schmitt and others, 2004). Decreased liver sizes, as reflected by the low HSI values (most $<1.0 \%$ ), were also found in bass although histopathological examination determined liver tissue to be normal in these fish. The highest vtg concentrations $(>0.28 \mathrm{mg} / \mathrm{mL})$ in male bass were measured from this site (fig. 29) and may indicate isolated estrogenic responses to environmental conditions at Station 312. A stage-0 male channel catfish was intersex, containing primarily testicular tissue with previtellogenic oocytes (fig. 29). External lesions were identified on $74 \%$ of carp from Station 312 and were related to parasitic infestations which caused frayed fins and nodules on the body surface and fins. Further studies are needed to determine the cause of anomalous biological endpoints in fish from this site.

\section{Green River, San Rafael, UT (Station 313)}

Station 313 was located on the Green River near the confluence of the San Rafael River. Carp and channel catfish were collected in September 2003. Mercury and Se were the only environmental contaminants that exceeded threshold criteria in fish (table 27). The highest $\mathrm{Hg}$ concentrations $(>0.3$ 


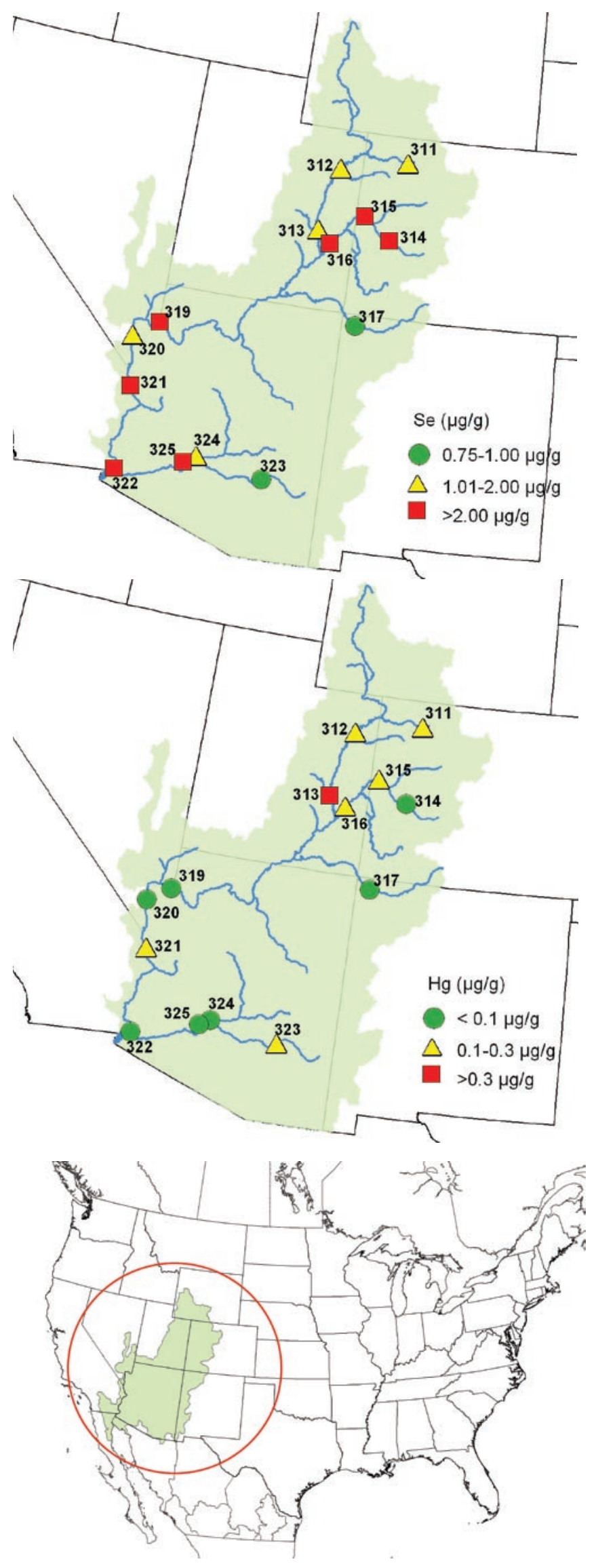

$\mu \mathrm{g} / \mathrm{g}$ ) of this study were measured in channel catfish from Station 313 (fig. 28) and may cause reproductive impairment in sensitive avian species (Wiener and Spry, 1996; Wiener and others, 2002). In addition, $\mathrm{Hg}$ concentrations in carp (>0.1 $\mu \mathrm{g} /$ g) may be a threat to piscivorous mammals (Yeardley and others, 1998). Selenium concentrations in carp ( $>1.6 \mu \mathrm{g} / \mathrm{g})$ may be hazardous to fish and piscivorous wildlife (fig. 28; Lemly, 1996). Tumors, a fibroma and a papilloma, were observed on catfish from Station 313. Other fish health indicators and reproductive biomarkers were not anomalous in fish from this site.

\section{Gunnison River, Delta, CO (Station 314)}

Station 314 was located on the Gunnison River near Delta, Colorado. Carp and brown trout were collected in September 2003. Few contaminants and biomarkers exceeded threshold criteria or appeared anomalous in fish (table 27). Selenium was the only contaminant to exceed protective criteria for fish and piscivorous wildlife (Lemly, 1996), and concentrations were $>2.9 \mu \mathrm{g} / \mathrm{g}$ in carp, the highest measured in this study, and $1.6 \mu \mathrm{g} / \mathrm{g}$ in trout (fig. 28). Natural weathering of Mancos shale is the primary source of Se in the Gunnison River Basin (Osmundson and others, 2000). Many carp also had relatively low body mass, as reflected by $\mathrm{CF}$ values $<0.8$ in these fish. Several studies have reported that lower CF values are associated with Se accumulation in fish (see review by Hamilton, 2004). Other fish health indicators and reproductive biomarkers were not anomalous in fish from this site.

\section{Colorado River, Loma, CO (Station 315)}

Station 315 was located on the CDR at the Loma Boat Launch downstream of Grand Junction, Colorado. Carp, largemouth bass, and channel catfish were collected in September 2003. Several elemental contaminants and biomarkers exceeded effects thresholds or appeared anomalous in fish (table 27). Selenium concentrations in carp and channel catfish $(>2.0 \mu \mathrm{g} / \mathrm{g})$ were potentially harmful to fish and piscivorous wildlife (fig. 28; Lemly, 1996). The Gunnison River confluence with the CDR, upstream of Station 315, contributes large amounts of Se from the marine shales of western Colorado to the CDR. Mercury concentrations were generally low, but concentrations in female bass $(0.1 \mu \mathrm{g} / \mathrm{g})$ were potentially hazardous to piscivorous mammals (Yeardley and others,

Figure 28. Maximum concentrations ( $\mu \mathrm{g} / \mathrm{g} w w)$ of selenium $(\mathrm{Se})$ and mercury $(\mathrm{Hg})$ in composite samples of whole fish. For $\mathrm{Se}$, concentrations should be $<0.75 \mu \mathrm{g} / \mathrm{g}$ ww to avoid toxicity to piscivorous wildlife and $<1.0 \mu \mathrm{g} / \mathrm{g}$ ww to avoid toxicity to fish (Lemly, 1996). A Hg concentration of $0.1 \mu \mathrm{g} / \mathrm{g}$ ww in fish has been suggested as a guideline for the protection of piscivorous mammals (Yeardley and others, 1998), and concentrations of 0.3 $\mu \mathrm{g} / \mathrm{g} w w$ can cause reproductive impairments in the common Ioon (Gavia immer, Wiener and Spry, 1996; Wiener and others, 2002). See Table 2 for station descriptions. 

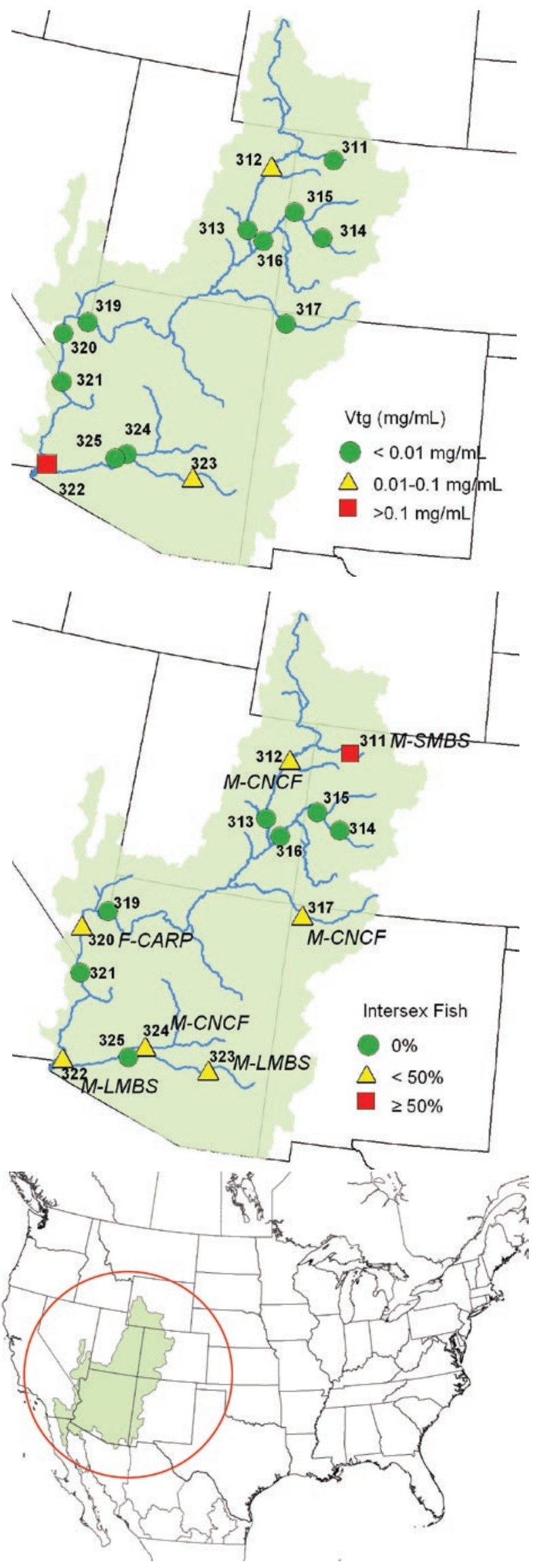

1998). External lesions were found on $75 \%$ of bass and $80 \%$ of channel catfish, which contributed to the elevated HAI scores in these taxa. Liver discoloration, granular liver, kidney, and spleen, and body surface lesions in bass and head and eye lesions and liver discoloration in channel catfish elevated HAI scores. Histopathological examination determined that liver, gonad, spleen, head kidney, and hind kidney tissues in most bass were infested with parasites, and external lesions collected for histopathology contained hemorrhages, inflammation, and repair from parasitic infestations. Similar to carp from Station 314, low CF values $(<0.8)$ were calculated for several carp and bass and may be associated with high Se concentrations (Hamilton, 2004). A SSI value of $1.74 \%$ was the highest calculated in male carp from this study and previous LRMN investigations. In contrast, SSI values in bass were $0.02-0.47 \%$; values $<0.03 \%$ have rarely been reported in previous LRMN studies. Reproductive biomarkers were not anomalous in fish from Station 315.

\section{Colorado River, Gold Bar Canyon, UT (Station 316)}

Station 316 was located in Gold Bar Canyon of the CDR downstream of Moab, Utah. Carp and channel catfish were collected in September 2003. Mercury and Se concentrations exceeded protective criteria for fish (table 27). Concentrations of $\mathrm{Hg}$ in carp $(0.13-0.14 \mu \mathrm{g} / \mathrm{g})$ and channel catfish $(0.18 \mu \mathrm{g} / \mathrm{g})$ may pose a threat to piscivorous mammals (fig. 28; Yeardley and others, 1998). Selenium concentrations were $>2.0 \mu \mathrm{g} / \mathrm{g}$ in carp and $>1.0 \mu \mathrm{g} / \mathrm{g}$ in channel catfish and may be hazardous to fish and piscivorous wildlife (fig. 28; Lemly, 1996). Fish health indicators and reproductive biomarkers were not anomalous in fish from this station.

\section{San Juan River, Hogback Diversion, NM (Station 317)}

Station 317 was located near the Hogback Diversion along the San Juan River downstream of Farmington, New Mexico. Carp and channel catfish were collected in September 2003. Several elemental contaminants and biomarkers exceeded threshold criteria or appeared anomalous in fish (table 27). Concentrations of $\mathrm{Hg}$ in carp and channel catfish $(\geq 0.1 \mu \mathrm{g} / \mathrm{g}$ ) may be harmful to piscivorous mammals (fig. 28; Yeardley and others, 1998). Selenium concentrations in carp $(>1.2 \mu \mathrm{g} / \mathrm{g})$ may pose a threat to fish and piscivorous wildlife (fig. 28; Lemly, 1996). Several biological endpoints were anomalous in channel catfish from this site. The greatest mean

Figure 29. Plasma vitellogenin (vtg) concentrations in male fish and occurrence of intersex fish. For vtg, thresholds indicate stations where at least one male had a detectable concentration of $v t g(>0.01 \mathrm{mg} / \mathrm{mL})$. Concentrations $>0.1 \mathrm{mg} / \mathrm{mL}$ indicate an estrogenic response to environmental contaminants. Percentage of CDRB fish with intersex (that is, gonads containing ovarian and testicular tissue). See Table 2 for station descriptions. M, male; F, female; SMBS, smallmouth bass; CNCF, channel catfish; LMBS, largemouth bass; CARP, common carp. 
HAI score (81) in this study was calculated for channel catfish from Station 317. Head and eye lesions, discolored livers, and granular spleens contributed to the elevated HAI scores. Liver tissue from fish at Station 317 had focal areas of inflammation and necrosis, and microsporidan cysts were occasionally observed within the hepatic parenchyma. A stage-0 male channel catfish was intersex, containing primarily testicular tissue with previtellogenic oocytes (fig. 29). The E/KT ratios were high $(>5.0)$ in multiple male channel catfish as a result of uniformly low KT concentrations $(<81 \mathrm{pg} / \mathrm{mL})$.

\section{Lower Colorado River Basin (Lower CDRB)}

The Lower CDRB includes Stations 319, 320, 321, and 322 on the CDR and Stations 323, 324, and 325 on the GR. Carp and bass or channel catfish were the target species, but flathead catfish were also collected from Station 323. The many NWRs in the Lower CDRB provide wintering areas and stopover points for migratory birds and are the primary source of water in some of the more arid areas. Water quality impairments in the Lower $\mathrm{CDRB}$ are primarily associated with agriculture and $\mathrm{Cu}$ mining. Agricultural drainage canals have transported pesticides and contributed to elevated concentrations of organochlorines and metals in fish from the GR, and these areas along the GR are important to Threatened and Endangered species, migratory birds, and waterfowl (Baker and others, 1992; King and others, 1997). Consequently, pesticides and Se associated with agricultural return flows could be harmful to fish and wildlife in the Lower CDR (Baker and others, 1992; CEPA, 2003). Selenium is transported in silt and sediment from the Upper CDRB to the Lower CDR, where high concentrations have been measured in fish since the 1980s (King and others, 1993). Other elemental contaminants including As, Cd, Cr, $\mathrm{Cu}$, and $\mathrm{Pb}$ exceeded protective criteria in fish from the Lower CDR in previous studies (Andrews and others, 1997). Copper and $\mathrm{Zn}$ impairments in the Upper GR are likely the result of extensive mining (ADEQ, 2004; King and Baker, 1995; NMED, 2000), and relatively high concentrations of $\mathrm{Cu}, \mathrm{Pb}$, and $\mathrm{Zn}$ have been measured in fish near these mines (Andrews and King, 1997). The GR is unique in that arid conditions cause ephemeral flows in some portions of the river, while the flow downstream of Phoenix is controlled by releases of wastewater treatment plant effluent and storm runoff (Anning, 2003; Arnold and others, 2004; Gebler, 1998). In addition, several lakes in southern Arizona including Alamo Lake on the Bill Williams River have $\mathrm{Hg}$ advisories for sport fish, and potential sources include historic ore milling and amalgamation processes, naturally mineralized soils, and atmospheric deposition (USEPA, 2004a). Studies in Las Vegas Bay have documented relatively high occurrences of environmental contaminants including PCBs, dioxins, furans, and PBDEs in sediments (Covey and Beck, 2001) and disruptions in reproductive fish health (Bevans and others, 1996; Gross and others, 2004; Patiño and others, 2003b).

\section{Colorado River, South Cove, AZ (Station 319)}

Station 319 was located at South Cove, Arizona, in the Gregg Basin of Lake Mead. Carp were collected in early October 2003. Selenium and several biomarkers exceeded threshold criteria or appeared anomalous in fish (table 27). Selenium concentrations in carp $(>2.1 \mu \mathrm{g} / \mathrm{g})$ were potentially hazardous to fish and piscivorous wildlife (fig. 28; Lemly, 1996). Liver discoloration, granular spleen and kidney tissues, and pale gills accounted for most of the elevated HAI scores. Macrophage aggregates in carp were $>15,000 \mu \mathrm{m}^{2}$, the largest measured in any LRMN study (Blazer and others, 2002; Hinck and others, 2004a; Schmitt and others, 2004), and carp from Station 319 were also among the oldest in our study. Steroid hormone concentrations were uniformly low in male carp, although they were in similar gonadal stages as carp from other stations. These low hormone concentrations may indicate an endocrine response in male carp from this site. A study in Las Vegas Bay of Lake Mead, downstream of South Cove, also found decreased KT concentrations in fish and concluded that exposure to wastewater effluent may have altered reproductive biomarkers in fish (Gross and others, 2004).

\section{Colorado River, Willow Beach, AZ (Station 320)}

Station 320 was located on the CDR downstream of Hoover Dam near the Willow Beach Fish Hatchery in Arizona. Carp were collected in late September 2003. Several contaminants and biomarkers exceeded threshold criteria or appeared anomalous in fish (table 27). Selenium concentrations in carp $(>1.6 \mu \mathrm{g} / \mathrm{g})$ may be hazardous to fish and piscivorous wildlife (fig. 28; Lemly, 1996). Concentrations of PCBs in male carp $(0.9 \mu \mathrm{g} / \mathrm{g})$ and female carp $(1.6 \mu \mathrm{g} / \mathrm{g})$ exceeded the NYSDEC guideline $(0.11 \mu \mathrm{g} / \mathrm{g})$ to protect wildlife (Newell and others, 1987). Relatively high HAI scores were attributed to discolored livers, granular spleen and kidney, and pale gills. Fibrotic fin lesions with inflammation and increased numbers of melanocytes were identified on two carp from Station 320. Similar to Station 319, MAs were $>15,000 \mu \mathrm{m}^{2}$ in several carp, and carp were older than those from other CDRB stations. One female carp was intersex, containing primarily ovarian tissue with a few spermatocytes (fig. 29). The lowest GSI value $(1.5 \%)$ and E2 concentration $(162 \mathrm{pg} / \mathrm{mL})$ from this station were mesured in the intersex female, but vtg data was unavailable for this fish. Intersex carp have not been found in previous LRMN studies; however, one intersex carp was reported in a recent Lake Mead study (Snyder and others, 2004). Patiño and others (2003b) suggested that low GSI values in male carp from Las Vegas Bay may be associated with exposure to environmental contaminants such as PCBs, dioxins, furans, and PBDEs. Aquatic biota in Las Vegas Bay and the Lower CDR below Hoover Dam may be at risk from exposure to these and other contaminants (for example, pharmaceuticals and personal care products) as the population of the Las Vegas area grows. 


\section{Colorado River, Needles, CA (Station 321)}

Station 321 was located on the CDR downstream of Needles, California near the Park Moabi Recreation Area. Carp and largemouth bass were collected in September 2003. Mercury, Se, and several biomarkers exceeded threshold criteria or were anomalous in fish (table 27). Mercury concentrations in female bass $(0.12 \mu \mathrm{g} / \mathrm{g})$ may be a threat to piscivorous mammals (fig. 28; Yeardley and others, 1998). Selenium concentrations in bass $(>1.8 \mu \mathrm{g} / \mathrm{g})$ and carp $(>2.5 \mu \mathrm{g} / \mathrm{g})$ exceeded protective criteria for fish and piscivorous wildlife (fig. 28; Lemly, 1996). Liver discoloration, granular spleen and kidney, and pale gills in carp and liver discoloration, granular liver, kidney, and spleen, and body surface lesions in bass accounted for most elevated HAI scores. A number of fish from this site exhibited fatty infiltration and degeneration of hepatocytes, large MAs, and a very high helminth parasite load in the liver, kidney, and spleen. Papillomas were also found on a carp and bass from Station 321. Similar to fish from Station 315, low CF values $(<0.8)$ in several carp and bass may be related to high Se concentrations in these fish (Hamilton, 2004). The HSI values in some bass were relatively low $(<1.0 \%)$. The $\mathrm{E} / \mathrm{KT}$ ratios were $<1.0$ in six female bass. Overall, E2 concentrations were low $(<300 \mathrm{pg} / \mathrm{mL})$ and KT concentrations were high $(>500 \mathrm{pg} / \mathrm{mL}$ ) compared to other CDRB female bass. Further studies are warranted to determine the cause of the multiple anomalous fish health indicators from this site.

\section{Colorado River, Imperial Dam, AZ (Station 322)}

Station 322 was located on the CDR downstream of the Imperial Dam. Carp and largemouth bass were collected in September 2003. Selenium and several biomarkers exceeded threshold criteria or appeared anomalous in fish (table 27). Selenium concentrations in bass $(>2.7 \mu \mathrm{g} / \mathrm{g})$ and carp $(>2.3$ $\mu \mathrm{g} / \mathrm{g}$ ) exceeded protective criteria for fish and piscivorous wildlife (fig. 28; Lemly, 1996). Mean HAI scores were relatively high in bass (103) and carp (49). Anomalies were similar to those found in fish from Station 321 and included liver discoloration, granular liver, kidney, and spleen, pale gills, and body surface lesions. The HSI values were low $(<1.0 \%)$ in multiple bass. Female and male bass were generally less advanced (all stage 1) than bass from other stations. Four of 10 male largemouth bass were intersex, containing primarily testicular tissue with few previtellogenic oocytes (fig. 29); other reproductive biomarkers including GSI, vtg, and steroid hormones appeared normal in the intersex fish. The highest vtg concentration in male carp $(>0.31 \mathrm{mg} / \mathrm{mL})$ was measured at this station (fig. 29) and was greater than concentrations in some CDRB female carp. Very low concentrations of E2 (31 $\mathrm{pg} / \mathrm{mL})$ and $\mathrm{KT}(53 \mathrm{pg} / \mathrm{mL})$ were also measured in this fish. Further investigation is needed to understand the anomalous reproductive biomarker responses in fish from Station 322.
Gila River, Hayden, AZ (Station 323)

Station 323 was located on the Upper GR near Hayden, Arizona. Carp, largemouth bass, and flathead catfish were collected in late August 2003. Mercury and several reproductive biomarkers exceeded threshold criteria or appeared anomalous (table 27). Mercury concentrations in carp $(0.14-0.16 \mu \mathrm{g} / \mathrm{g})$ and male bass $(0.1 \mu \mathrm{g} / \mathrm{g})$ may be hazardous to piscivorous mammals (fig. 28; Yeardley and others, 1998). Gill tissue was histologically normal for most bass and flathead catfish at Station 323, but focal areas of hyperplasia leading to fused secondary lamellae were observed in some fish. Gill tissue from most carp at Station 323 had some hyperplasia and fusion of secondary lamellae, which may relate to contaminant exposure, but monogenetic trematodes were also present in the gill tissue. Like Station 322, female and male bass were generally less advanced (all stage 1$)$ and were younger $(<2$ y) than bass from other stations. Two of five male largemouth bass were intersex. KT concentrations were relatively low in the intersex bass as reflected in the E/KT ratios $>1.0$. Intersex fish also had greater GSI values (0.96\%) compared to female bass from this station. Concentrations of vtg were $>0.1 \mathrm{mg} / \mathrm{mL}$ in three male carp and may indicate an estrogenic response in these fish. Relatively low concentrations of E2 $(<400 \mathrm{pg} / \mathrm{mL})$ and $\mathrm{KT}(<200 \mathrm{pg} / \mathrm{mL})$ were measured in female carp, which did not appear to be related to differences in gonadal stage. More studies are needed to determine the cause of anomalous reproductive biomarkers in fish from this site.

\section{Gila River, Phoenix, AZ (Station 324)}

Station 324, located on the GR downstream of its confluence with the Salt River near Estrella Park, has a history of pesticide contamination in fish. Carp, largemouth bass, and channel catfish were collected in late August 2003. Several contaminants and biomarkers exceeded threshold criteria or appeared anomalous in fish (table 27). Selenium concentrations in carp $(>1.7 \mu \mathrm{g} / \mathrm{g})$ and channel catfish $(>0.6 \mu \mathrm{g} / \mathrm{g})$ exceeded protective criteria for fish and piscivorous wildlife (fig. 28; Lemly, 1996). The greatest concentrations of banned organochlorine pesticides or pesticide products including $p, p$ '-DDE, toxaphene, total chlordanes, dieldrin, endrin, and hexachlorobenzene were in fish from Station 324. Concentrations of pentachlorobenzene, PCA, $\gamma-\mathrm{HCH}$, dacthal, and methoxychlor, all currently registered pesticides or pesticide products, were also relatively high in fish from Stations 324. Concentrations of $p, p$ '-DDE and toxaphene exceeded available protective criteria. Concentrations of $p, p^{\prime}$-DDE in carp $(>0.3 \mu \mathrm{g} / \mathrm{g})$ and channel catfish $(>0.6 \mu \mathrm{g} / \mathrm{g})$ may be harmful to sensitive avian species (Anderson and others, 1975) and other wildlife (Newell and others, 1987). Concentrations of $o, p$ 'DDD $(0.006-0.010 \mu \mathrm{g} / \mathrm{g})$ were also relatively high. Toxaphene concentrations in male channel catfish $(0.50 \mu \mathrm{g} / \mathrm{g})$ exceeded toxicity thresholds to protect fish (Eisler and Jacknow, 1985; Jarvinen and Ankley, 1999). Concentrations of PCBs in all samples exceeded the NYSDEC guideline $(0.11 \mu \mathrm{g} / \mathrm{g})$ to protect wildlife (Newell and others, 1987), and TCDD-EQs 
concentrations in carp and channel catfish also exceeded the toxicity threshold for avian wildlife ( $5 \mathrm{pg} / \mathrm{g}$; Nosek and others, 1992). Hepatic EROD activities were generally greater in female and male carp from Station 324 compared to other stations and exceeded basal EROD activity in carp, which may indicate exposure to PAHs, PCBs, and dioxins (Schmitt and others, 2002). SSI values were relatively low in bass $(\leq 0.03 \% ; n=2)$ and channel catfish $(\leq 0.11 \%)$, but histopathological examination determined spleen tissue to be normal in most fish. Decreased spleen sizes have been associated with exposure to PCBs, PAHs, and metals (see Schmitt and Dethloff, 2000). A hematoma on an opercle was identified on a carp from Station 324. The gonadal development of male carp, male bass, and channel catfish at Station 324 were less advanced compared to male carp, male bass, and channel catfish from other CDRB sites. Histopathological examination revealed that the testes of these male fish were abnormal, containing calcified, poorly developed, edemic, or parasitic tissues; these abnormalities were not found in fish from other stations. Some of these observations have been previously associated with exposure to wastewater effluent in carp (Diniz and others, 2005; Lavado and others, 2004). Moreover, one male channel catfish was intersex (fig. 29). The GSI values in male carp were low $(<1.0 \%)$, which may be associated with estrogenic chemicals in the water (Diniz and others, 2005; Hassanin and others, 2002; Lavado and others, 2004). Relatively low vtg concentrations $(<2.0 \mathrm{mg} / \mathrm{mL})$ were measured in female carp. These data indicate that contaminants may be interfering with steroidogenesis. Many of the organochlorine pesticides measured at this site have been associated with reproductive effects and histological changes in gill, liver, and kidney tissues in fish (ATSDR, 2002; McDonald, 1991; Ortiz and others, 2003; Shukla and Pandey, 1986; USEPA, 2002; Versonnen and others, 2004). Studies have reported that $o, p$ ' homologs were estrogenic and caused delayed gonad development and altered plasma vtg concentrations (Ackerman and others, 2002; Donohoe and Curtis, 1996; Guillette and others, 1996; Metcalfe and others, 2000; Papoulias and others, 2003; Toppari and others, 1996). Wastewater effluent dominates the water in the GR downstream of Phoenix, and reproductive effects in fish from Station 324 may be associated with contaminants in the effluent. Slow, intermittent flows and high water temperatures $\left(>25^{\circ} \mathrm{C}\right)$ also need to be considered as they may also influence reproductive biomarker responses. Further investigations are warranted to determine the cause(s) of altered reproductive biomarkers in multiple taxa from this site and to continue to monitor pesticide contamination in fish from the GR.

\section{Gila River, Arlington, AZ (Station 325)}

Station 325 was located on the GR near Arlington, Arizona. Carp and largemouth bass were collected in August 2003. Several environmental contaminants exceeded threshold criteria (table 27). Selenium concentrations potentially hazardous to fish and piscivorous wildlife were measured in carp
(>2.1 $\mu \mathrm{g} / \mathrm{g})$ and bass $(>1.4 \mu \mathrm{g} / \mathrm{g}$; Lemly, 1996). Like Station 324, fish from Station 325 had high concentrations of banned and currently registered pesticides or pesticide products. Specifically, concentrations of $p, p^{\prime}$-DDE, toxaphene, endosulfan II, endosulfan sulfate, and methoxychlor were greatest in fish from Station 325. Concentrations of pentachlorobenzene, PCA, $\gamma-\mathrm{HCH}$, dacthal, and methoxychlor, all currently registered pesticides or pesticide products, were also relatively high in fish from Stations 325. Like Station 324, p, $p$ '-DDE and toxaphene exceeded protective criteria. Concentrations of $p, p$ '-DDE in carp $>1.3 \mu \mathrm{g} / \mathrm{g})$ and channel catfish $(>1.6 \mu \mathrm{g} / \mathrm{g})$ may be harmful to sensitive avian species (Anderson and others, 1975) and other wildlife (Newell and others, 1987). Concentrations of $o, p$ '-DDD $(0.024-0.037 \mu \mathrm{g} / \mathrm{g})$ were the greatest measured in the study. Toxaphene concentrations in carp $(0.50$ $\mu \mathrm{g} / \mathrm{g})$ and bass $(0.60 \mu \mathrm{g} / \mathrm{g})$ exceeded toxicity thresholds to protect fish (Eisler and Jacknow, 1985; Jarvinen and Ankley, 1999). Although fish health indicators and reproductive biomarkers were not anomalous at this site, many of the organochlorine pesticides measured at this site have been associated with reproductive, developmental, and histological effects in fish (Ackerman and others, 2002; ATSDR, 2002; Donohoe and Curtis, 1996; Guillette and others, 1996; McDonald, 1991; Metcalfe and others, 2000; Ortiz and others, 2003; Papoulias and others, 2003; Shukla and Pandey, 1986; Toppari and others, 1996; USEPA, 2002; Versonnen and others, 2004). Similar to bass from Stations 322 and 323, female and male bass were generally less advanced (stage 1 and 0 , respectively) and were younger $(<3 \mathrm{y})$ at Station 325 compared to bass from most other sites. Pesticide contamination in fish should be continued to be monitored at this site.

\section{Conclusions}

Few CDRB fish had evidence of being exposed to extremely high concentrations of toxic chemicals, but concentrations of some organochlorine pesticides and elemental contaminants were elevated and may pose a risk to aquatic systems and fish-eating wildlife. Fish from several CDRB stations may have responded to chronic contaminant exposure as indicated by fish health indicator and reproductive biomarker results.

The agricultural industry in the Lower CDRB is one of the most productive in the U.S. and relies heavily on irrigation canals and pesticide applications for high crop yields. Pesticides have also been heavily applied in the GR for residential use (Gellenbeck and Anning, 2002). Chemicals such as arsenic-based defoliants, stable organic herbicides and insecticides, metals, and salts are potentially accessible to wildlife (Aritola and Dubois, 1995). Pre-emergent pesticides (for example, simazine, trifluralin, and dacthal) are most frequently detected in the GR from December to April (Gellenbeck and Anning, 2002), which indicates that fish may be exposed to the contaminants prior to spawning. Concentrations of 
pesticides were generally less than the current established water-quality limits, however. Previous studies have reported that fish and wildlife may be at risk from $p, p^{\prime}$-DDT and other pesticides in agricultural areas of the GRB and Lower CDRB (ADEQ, 1992; Baker and others, 1992; García-Hernández and others, 2001, 2006; Gebler, 2000; King and others, 1993;1997; Schmitt and others, 1999), and multiple fish consumption advisories are listed for these waters (USEPA, 2004a). Our findings support these conclusions and also indicate that unlisted and restricted use organochlorine pesticide concentrations (for example, PCA, dacthal, endosulfan) are elevated in the GR and should be monitored. Although concentrations were generally low in CDRB fish, restricted use and unlisted organochlorine pesticides have been associated with histological, developmental, and reproductive effects in fish and other wildlife (ATSDR, 2002; McDonald, 1991; Ortiz and others, 2003; Shukla and Pandey, 1986; USEPA, 2002; Versonnen and others, 2004).

Concentrations of $p, p$ '-DDE and toxaphene in the Lower GRB may be hazardous to fish and piscivorous wildlife; $o, p$ '-DDD, PCBs, TCDD-EQs, and EROD activity were also elevated in fish downstream of Phoenix, Arizona. PBDEs were also detected in fish samples from Stations 324 and 325 in the GR. Fish from Station 324 (Phoenix, Arizona) also had several reproductive biomarkers that were noteworthy. The gonadal development of male carp, male bass, and channel catfish at Station 324 were less advanced compared to male carp, male bass, and channel catfish from other CDRB sites, and reduced gonad size (that is, low GSI values) was also noted in male carp and bass from Station 324. In addition, vtg concentrations were relatively low in female carp from Station 324. These anomalous biomarkers were observed in fish from Station 324 but not Station 325 further downstream on the GR, where fish were collected several days prior to those from Station 324. We conclude that municipal inputs including wastewater treatment plant effluent and urban runoff from the Phoenix metropolitan area are likely involved in the reproductive biomarker responses in fish from Station 324.

The GR and its tributaries have ephemeral or intermittent flows and are primarily recharged by irrigation return water, storm water, and wastewater treatment plant effluent (Anning, 2003; Gebler, 1998). Aquatic invertebrate community data indicated that water quality in effluent-dependent reaches near Phoenix was poor (Gebler, 1998). Arnold and others (2004) reported that effluent-dominated waters near Tucson and Phoenix contained the highest concentrations of known estrogenic compounds in a nationwide survey and have the potential to negatively impact aquatic life. Moreover, estrogenic chemicals have been correlated with inhibited testes growth and delayed gonadal maturation (Diniz and others, 2005; Hassanin and others, 2002; Lavado and others, 2004). Exposure to estrogenic chemicals including $o, p^{\prime}$-DDT and $o, p^{\prime}$-DDE in fish have been associated with decreased HSI values, plasma vtg concentrations, and lipid levels (Donohoe and Curtis, 1996) and altered GSI values (Papoulias and others, 2003; Ungerer and Thomas, 1996). Continuous exposure to estro- genic compounds such as $o, p^{\prime}$-DDT from in ovo and throughout early development can affect reproductive endpoints in fish (Metcalfe and others, 2000). Anomalous reproductive biomarkers in fish from Station 324 are likely associated with contaminants in the wastewater-dominated effluent in the GR downstream of Phoenix. Altered reproductive biomarkers were also noted in fish from Stations 319 and 320 near Lake Mead. Several studies concluded that exposure to wastewater effluent and municipal runoff in Lake Mead may be altering reproductive biomarkers in fish (Gross and others, 2004; Patiño and others, 2003b). Studies are needed to determine the effects and ecological significance of wastewater effluent and agricultural runoff on fish from these areas. As found in our study, new or emerging contaminants such as PBDEs are present in effluent downstream of urban areas but their effects on fish are largely unknown. More studies, particularly downstream of Las Vegas and Phoenix, are warranted to describe the distribution and potential effects of these new contaminant concentrations in aquatic systems. Other known estrogenic compounds including nonlyphenol and ethoxylates commonly found in effluents should also be monitored. Furthermore, investigations are needed that describe how contaminant effects in fish may be altered in arid environments like the GRB.

Selenium-rich soils are produced by the weathering of marine shales and are widespread in the arid and semiarid regions of the U.S. including the Upper CDRB. Substantial irrigation is required for agricultural crop production in the Upper CDRB, and water in irrigation return flows may be highly contaminated with dissolved selenium salts that have been leached from the soil (Lemly, 1996). Our study addresses recommendations of previous monitoring efforts to examine the effects of Se in fish and correlate degraded fish health with contaminants (Abell, 1994). Previous investigations have determined Se concentrations were elevated in sediment, water, and biota in the Upper CDRB (Abell, 1994; Butler and Leib, 2002; Deacon and Stephens, 1998; Engberg, 1999; Schmitt and others, 1999; Seiler and others, 1999; Spahr and others, 2000; Stephens and others, 1992). However, some of the highest Se concentrations in fish have been reported in the Lower CDR (Andrews and others, 1997; Baker and others, 1992; King and others, 1993; Schmitt and others, 1999). Elevated Se concentrations in the Lower CDR are likely the result of transporting Se from the Upper CDRB rather than sources from local agricultural practices (Welsh and Maughan, 1994). Our findings support conclusions from previous CDRB studies that Se concentrations may pose a risk to fish and piscivorous wildlife. Concentrations of Se exceeded protective criteria for fish, piscivorous wildlife, or both at all CDRB stations. Concentrations were greatest in carp from Stations 314, 321, 322, and 325 and bass from Station 322, but teratogenic defects (for example, spine, head, and mouth deformities) associated with selenium toxicosis were rare in fish from these sites (Lemly, 1997). Edema, exopthalmus, and cataracts, which were noted in fish from Stations 314, 315, 320 and 322, can also be selenium-induced (Lemly, 1997). However, the lack of terato- 
genic defects in CDRB fish does not preclude that the risk to Se is minimal. Multiple studies have documented reproductive effects in fish (egg to adult) exposed to high Se concentrations (Gillespie and Baumann, 1986; Schultz and Hermanutz, 1990; Hermanutz and others, 1992; Coyle and others, 1993; Hamilton and others 2005b, 2005c). Studies examining the effects of elevated Se concentrations in multiple life stages of CDRB fish are limited to the razorback sucker (Hamilton and others, 2005a, 2005b, 2005c), but studies with other species are warranted. The effects of Se on reproduction of the endangered razorback sucker in the Lower CDRB, where Se concentrations were highest in our study, are unknown but could provide relevant information on their limited populations in the Lower CDR. High Se concentrations have been associated with low $\mathrm{CF}$ values from fish being underweight (Hamilton, 2004). Low CF values were noted in fish from Stations 314 , 315, and 321 where Se concentrations were the highest. Our results indicate that Se concentrations may be associated with biomarker responses in CDRB from several stations. Further investigations are warranted to determine cause-effect relationships between $\mathrm{Se}$ and biomarkers (reproductive, morphological, and molecular) in CDRB fish.

In addition to the extensive agriculture in the CDRB, mining is an important industry. Minerals including $\mathrm{Cu}$, $\mathrm{Au}, \mathrm{Pb}$, and $\mathrm{Zn}$ have been heavily mined in much of the CDRB, and uranium, coal, oil, and natural gas have also been exploited. Many $\mathrm{Cu}$ mines are located along the GR in New Mexico and Arizona and are a primary source of contaminants in the Middle GR (King and Baker, 1995). Fifteen Cu smelters in this area are point sources for sulfur oxides, toxic metals (for example, $\mathrm{As}, \mathrm{Pb}, \mathrm{Hg}$ ), fine particulates, and acid precipitation. One smelter in Hayden, Arizona (Station 323) is located near the GR, and storm water runoff, erosion of mine tailings, and emissions from the smelters may adversely impact threatened and endangered species in this area (G. Beatty, oral communication). Several studies have reported relatively high $\mathrm{Cu}$ concentrations in fish from the GR (Baker and others, 1992; King and others, 1997); our results are similar. Concentrations of $\mathrm{Cu}$ were significantly higher in bass from Station 323 than other CDRB stations. Although tissue-based criteria for $\mathrm{Cu}$ are unavailable for piscivorous wildlife (Eisler, 1997), several studies have correlated physiological effects in fish with $\mathrm{Cu}$ exposure (see review by Handy, 2003). Monitoring histological changes in fish, especially those from the GR, are likely necessary to understand the effects of $\mathrm{Cu}$ exposure to fish. Large natural gas and coal deposits are located in the Upper $\mathrm{CDRB}$, and New Mexico has the largest reserves and production of CBM (NMRD, 2003). Extraction and processing of these natural resources have caused degraded water quality in the SJB and the Green River. Continued monitoring of environmental contaminants and their effects in aquatic biota is needed in these areas as mining operations expand to meet consumer demands.

Mercury sources in the CDRB include historic ore milling and amalgamation processes, naturally mineralized soils, and atmospheric deposition (USEPA, 2004a). King and others
(1993) concluded that $\mathrm{Hg}$ concentrations did not pose a risk to piscivorous wildlife in the Lower CDRB; a conclusion that was also supported by our data. Large coal beds found in the Green River, Yampa River, and San Juan River Basins also contain $\mathrm{Hg}$, which can be extracted during coal cleaning and released from coal-fired power plants (Tewalt and others, 2001). Fish from these areas in our study had among the highest $\mathrm{Hg}$ concentrations and exceeded protective criteria for fish and wildlife. Mercury deposition from coal-fired power plants in New Mexico (near Station 317) may have contributed to the fish consumption advisories for nearby reservoirs and rivers (Abell, 1994; Melancon and others, 1979). In addition, acid deposition from power plants in the Yampa River Basin at Craig, Colorado (near Station 311) has been associated with reproductive problems in amphibians from nearby waters (Turk and Campbell, 1997). Plasma E2 concentrations were relatively high in male smallmouth bass from Station 311, and evidence of ovotestis was found in $70 \%$ of these males, which indicates reproductive biomarker responses in these fish. This occurrence of intersex is one the most severe reported by the BEST-LRMN Program. The cause of intersex in these fish is unknown, although the condition has been reported in similarly high proportions in smallmouth bass in other U.S. river basins (Blazer and others, 2002; Blazer, 2006). Liney and others (2005) concluded that intersex is age-related and occurs at higher incidences in adults exposed to estrogenic compounds during early development. Blazer (2006) suggests that intersex in smallmouth bass from the Potomac River were caused by a mixture of estrogenic chemicals from various sources including human wastewater, agricultural runoff, industrial discharge, and atmospheric deposition. These types of endocrine disrupting sources are not found near Station 311. However, the high occurrence of intersex and high E2 concentrations in male smallmouth bass along with the relatively high vtg concentrations in female smallmouth bass from this site indicate that the reproduction pathway in these fish has been affected and needs to be investigated further.

The demand for water continues to increase as the human population expands and drought conditions persist throughout the CDRB. The magnitude and type of chemical contaminants released in the CDRB are likely to expand, and water quality will decline as industrial and municipal discharges increase. Toxic trace elements will likely continue to leach into river systems as a result of mining operations and irrigated agriculture. Densely populated areas including Las Vegas and Phoenix will continue to introduce emerging or new generation chemicals such as pharmaceuticals and person care products to $\mathrm{CDRB}$ waters. The effects of these contaminants to aquatic biota are largely unknown. Biological responses would be expected to increase in magnitude as chemical concentrations increase, which may ultimately place fish populations at risk. Results from this study and other investigations indicate that continued monitoring is needed to identify consistently degraded sites and those with emerging problems, specifically those in the GRB. Focused investigations are also needed in 
the CDRB to document chemical sources, interactions with other factors, and cause-effect relationships.

\section{References}

Abell, R., 1994, San Juan River basin water quality and contaminants review, volumes I and II: University of New Mexico, Department of Biology, 801 p.

Ackerman, G.E., Brombacher, E., and Fent, K., 2002, Development of a fish reporter gene system for the assessment of estrogenic compounds and sewage treatment plant effluents: Environmental Toxicology and Chemistry, v. 21, p. 18641875 .

Adams, S.M., Ham, K.D., and Beauchamp, J.J., 1994, Application of canonical variate analysis in the evaluation and presentation of multivariate biological response data: Environmental Toxicology and Chemistry, v. 13, no. 10, p. 1673-1683.

Adams, S.M., Brown, A.M., and Goede, R.W., 1993, A quantitative health assessment index for rapid evaluation of fish condition in the field: Transactions of the American Fisheries Society, v. 122, p. 63-73.

Adams, S.M., Crumby, W.D., Greeley, M.S., Jr., Ryon, M.G., and Schilling, E.M., 1992a, Relationships between physiological and fish population responses in a contaminated stream: Environmental Toxicology and Chemistry, v. 11, no. 11, p. 1549-1557.

Adams, S.M., Crumby, W.D., Greeley, M.S., Jr., Shugart, L.R., and Saylor, C.F, 1992b, Responses of fish populations and communities to pulp mill effluents: a holistic assessment: Ecotoxicology and Environmental Safety, v. 243, p. 347-60.

Adams, S.M., and McLean, R.B., 1985, Estimation of largemouth bass, Micropterus salmoides lacepede, growth using the liver somatic index and physiological variables: Journal of Fish Biology, v. 26, p. 111-126.

Adams, S.M., McLean, R.B., and Parrotta, J.A., 1982, Energy partitioning in largemouth bass under conditions of seasonally fluctuating prey availability: Transactions of the American Fisheries Society, v. 111, no. 5, p. 549-558.

Agency for Toxic Substances and Disease Registry (ATSDR), 2000, Toxicological profile for endosulfan, U.S. Department of Health and Human Services, Atlanta, Georgia (available at URL: http://www.atsdr.cdc.gov/toxprofiles/tp41.pdd), 323 p.

Agency for Toxic Substances and Disease Registry (ATSDR), 2002, Toxicological profile for methoxychlor, U.S. Department of Health and Human Services, Atlanta, Georgia (available at URL: http://www.atsdr.cdc.gov/toxprofiles, tp47.pd], 290 p.
Agius, C., 1979, The role of melano-machrophage centres in iron storage in normal and diseased fish: Journal of Fish Diseases, v. 2, p. 337-343.

Agius, C., 1980, Phylogenetic development of melano-macrophage centres in fish: Journal of Zoology, v. 191, p. 11-31.

Agius, C., and Roberts, R.J., 1981, Effects of starvation on the melano-macrophage centres of fish: Journal of Fish Biology, v. 19, p. 161-169.

Ahlborg, U.G., Becking, G.C., Birnbaum, L.S., Brouwer, A., Derks, H.J., Feeley, M., Golor, G., Hanberg, A., Larsen, J.C., Liem, A.K., Safe, S.H., Schlatter, C., Waern, F., Younes, M., and Yrjnheikki, E., 1994, Toxic equivalency factors for dioxin-like PCBs: Chemosphere, v. 28, p. 1049 1067.

Allen, Y., Scott, A.P., Matthiessen, P., Haworth, S., Thain, J.E., and Feist, S., 1999, Survey of estrogenic activity in United Kingdom estuarine and coastal waters and its effects on gonadal development of the flounder Platichthys flesus: Environmental Toxicology and Chemistry, v. 18, p. 17911800 .

Anderson, J.B., Tsivoglou, E.C., and Shearer, S.D., 1963, Effects of uranium wastes on biological fauna of the Animas River (Colorado-New Mexico), in Schultz, V. and Klement, A.W., Jr., eds., Radioecology: New York, N.Y., Reinholt Publishing Company and American Institute of Biological Sciences, p. 373-383.

Anderson, D.W., Jehl, J.R., Jr., Risebrough, R.W., Woods, L.A., Jr., DeWeese, L.R., and Edgecomb, W.G., 1975, Brown pelicans: improved reproduction off the southern California coast: Science, v. 190, p. 806-808.

Andrews, B.J., and King, K.A., 1997, Environmental contaminants in sediment and fish of Mineral Creek and the middle Gila River, Arizona: U.S. Fish and Wildlife Service Report 22410-1130-2F31, 20 p.

Andrews, B., King, K., and Baker, D., 1997, Environmental contaminants in fish and wildlife of Havasu National Wildlife Refuge, Arizona: U.S. Fish and Wildlife Service Report 22410-1131-2N17, $71 \mathrm{p}$

Anning, D.W., 2003, Assessment of selected inorganic constituents in streams in the Central Arizona Basin Study Area, Arizona and Northern Mexico, through 1998: U.S Geological Survey Water Resources Investigations Report 03-4063, 127 p.

Arnold, R.G., Quanrud, D.M., Karpiscak, M.P., and Gerba, C.P., 2004, Water quality: estrogens and effluent: University of Arizona, Water Sustainability Program, 2 p.

Artiola, J.F., and Dubois, J., 1995, Arizona's agricultural ecosystems, in Arizona comparative environmental risk project, section 2: ecosystems, $12 \mathrm{p}$. 
Arizona Department of Environmental Quality (ADEQ), 1992, Analysis for pesticide residues in soils west central Phoenix: ADEQ, Water Assessment Section, Pesticides Unit.

Arizona Department of Environmental Quality (ADEQ), 2002, Pesticide Contamination Prevention Program Report, Arizona Department of Environmental Quality A.R.S. 49-303. $\mathrm{B}, 18 \mathrm{p}$.

Arizona Department of Environmental Quality (ADEQ), 2004, Surface waters assessed as impaired 2002 303(d) list as approved by EPA, Appendix D, in The status of water quality in Arizona - 2002: ADEQ, 3 p.

Arizona Department of Health Services, 2002, Public Health Assessment - ASARCO Hayden Smelter Site, Hayden, Gila County, Arizona. (available at URL: http://www.atsdr.cdc. gov/HAC/PHA/asarcohayden/asa_toc.html).

Baker, D.L., King, K.A., Kepner, W.G., and Krausmann, J.D., 1992, Pre-reconnaissance investigation of water quality, bottom sediment, and biota associated with irrigation drainage in Yuma Valley, Arizona: U.S. Fish and Wildlife Service, Environmental Contaminants Program, $31 \mathrm{p}$.

Barber, T.R., Fuchsman, P.C., Chappie, D.J., Sferra, J.C., Newton, F.C., Sheehan, P.J., 1997, Toxicity of hexachlorobenzene to Hyalella azteca and Choronomus tentans in spiked sediment bioassays: Environmental Toxicology and Chemistry, v.16, p. 1716-1720.

Barr, J.F., 1986, Population dynamics of the common loon (Gavia immer) associated with mercury-contaminated waters in northwestern Ontario: Canadian Wildlife Service Occasional Paper 56.

Barry, T.P., Santos, T., Furukawa, K., Aida, K., and Hanyu, I., 1990, Steroid profiles during spawning in male common carp: General Comparative Endocrinology, v. 80, p. 223.

Baumann, P.C., Mac, M.J., Smith, S.B., and Harshbarger, J.C., 1991, Tumor frequencies in walleye (Stizostedion vitreum) and brown bullhead (Ictalurus nebulosus) and sediment contaminants in tributaries of the Laurentian Great Lakes: Canadian Journal of Fisheries and Aquatic Sciences, v. 48, no. 9 , p. 1804-1810.

Beamish, F.W.H., Jebbink, J.A., Rossiter, A., and Noakes, D.L.G., 1996, Growth strategy of juvenile lake sturgeon (Acipenser fulvescens) in a northern river: Canadian Journal of Fisheries and Aquatic Sciences, v. 53, p. 481-489.

Bengtsson, B.E., 1979, Biological variables, especially skeletal deformities in fish, for monitoring marine pollution, in Bascom, W., ed., The assessment of sublethal effects of pollutants in the sea: Philosophical Transactions of the Royal Society of London, v. 286B, no. 1015, p. 457-464.
Bengtsson, B.E., Bengtsson, A., and Himberg, M., 1985, Fish deformities and pollution in some Swedish waters: Ambio, v. 14 , no. 1 , p. $32-35$.

Berg, A., and Grimaldi, E., 1967, A critical interpretation of the scale structures used for the determination of annuli in fish growth studies: Memorie dell Istituto Italiano di Idrobiologia, v. 21, p. 225-239.

Bevans, H.E., Goodbred, S.L., Miesner, J.F., Watkins, S.A., Gross, T.S., Denslow, N.D., and Schoeb, T., 1996, Synthetic organic compounds and carp endocrinology and histology in Las Vegas Wash and Las Vegas and Callville Bays of Lake Mead, 1992 and 1995: U.S. Geological Survey WaterResources Investigations Report 96-4266, 12 p.

Bevans, H.E., Lico, M.S., and Lawrence, S.J., 1998, Water quality in the Las Vegas Valley area and the Carson and Truckee River basins, Nevada and California, 1992-1996: U.S. Geological Survey Circular 1170, 47 p.

Beyer, W.N., Heinz, G.H., and Redmon-Norwood, A.W., eds., 1996, Environmental contaminants in wildlife: interpreting tissue concentrations: Boca Raton, Fla., Lewis Publishers, $494 \mathrm{p}$.

Bidwell, C.A., and Carlson, P.M., 1995, Characterization of vitellogenin from white sturgeon, Acipenser transmontanus: Journal of Molecular Evolution, v. 41, no. 1, p. 104-112.

Blazer, V.S., 2006, Biological effects of endocrine modulators in fishes: Presented at the Manta Seminar of the Maryland Department of Natural Resources, January 12, 2006. (available at URL http://www.dnr.state.md.us/streams/).

Blazer, V.S., 2002, Histopathological assessment of gonadal tissue in wild fishes: Fish Physiology and Biochemistry, v. 26 , p. 85-101.

Blazer, V.S., Dethloff, G.M., and Wright, B., 2002, Fish health indicators, in Biomonitoring of Environmental Status and Trends (BEST) Program: Environmental contaminants and their effects on fish in the Mississippi River basin: U.S. Geological Survey Biological Science Report 2002-0004, p. 89-134.

Blazer, V.S., Facey, D.E., Fournie, J.W., Courtney, L.A., and Summers, J.K., 1994, Macrophage aggregates as indicators of environmental stress, in Stolen, J.S., and Fletcher, T.C., eds., Modulators of fish immune responses: volume one, models for environmental toxicology, biomarkers, immunostimulators: Fair Haven, N.J., SOS Publications, p. 169-185.

Blazer, V.S., Fournie, J.W., and Weeks-Perkins, B.A., 1997, Macrophage aggregates: biomarker for immune function in fishes?, in Dwyer, F.J., Doane, T.R., and Hinman, M.L., eds., Environmental toxicology and risk assessment: modeling and risk assessment, vol 6: American Society for Testing and Materials, ASTM Special Technical Publication 1317. 
Blazer, V.S., Wolke, R.E., Brown, J., and Powell, C.A., 1987, Piscine macrophage aggregate parameters as health monitors: effect of age, sex, relative weight, season and site quality in largemouth bass (Micropterus salmoides): Aquatic Toxicology, v. 10, no. 4, p. 199-215.

Blus, L. J., 1996, DDT, DDD, and DDE in birds, in Beyer, W.N., Heinz, G.H., Redmon-Norwood, A.W., eds., Environmental contaminants in wildlife: interpreting tissue concentrations: Boca Raton, Fla., Lewis Publishers, p. 49-71.

Bon, R.L., and Wakefield, S., 1999, Large mine permits in Utah: Utah Geological Survey Public Information Series 67, $5 \mathrm{p}$.

Bowman, C.J., Kroll, K.J., Gross, T.G., and Denslow, N.D., 2002, Estradiol-induced gene expression in largemouth bass Micropterus salmoides: Molecular and Cellular Endocrinology, v. 196, p. 67-77.

Bromage, N.R., Whitehead, C., and Breton, B., 1982, Relationships between serum levels of gonadotropin, oestradiol $17-\beta$ and vitellogenin in the control of ovarian development in the rainbow trout: General and Comparative Endocrinology, v. 47, p. 366-376.

Brown, R.M., 1927, The utilization of the Colorado River: Geographical Review, v. 17, p. 453-466.

Brown, C.L., and George, C.T., 1985, Age-dependent accumulation of macrophage aggregates in the yellow perch Perca flavescens (Mitchell): Journal of Fish Diseases, v. 8, p. 136-138.

Brown, S.B., Adams, B.A., Cyr, D.G., and Eales, J.G., 2004a, Contaminants effect on the teleosts fish thyroid: Environmental Toxicology and Chemistry, v. 23, p. 1680-1701.

Brown, P., Green, C., Sivakumaran, K.P., Stoessel, D., and Giles, A., 2004b, Validating otolith annuli for annual age determination of common carp: Transactions of the American Fisheries Society, v. 133, p. 190-196.

Brumbaugh, W.G., Krabbenhoft, D.P., Helsel, D.R., Wiener, J.G., and Echols, K.R., 2001, A national pilot study of mercury contamination of aquatic ecosystems along multiple gradients: bioaccumulation in fish: U.S. Geological Survey, Biological Science Report 2001-0009, 25 p.

Burdick, G.E., Harris, E.J., Dean, H.J., Walker, T.M., Skea, J., and Colby, D., 1964, Accumulation of DDT in lake trout and the effect on reproduction: Transactions of the American Fisheries Society, v. 93, p. 127-136.
Butler, D., Wright, W., Stewart, K., Osmundson, B., Krueger, R., and Crabtree, D., 1996, Detailed study of selenium and other constituents in water, bottom sediment, soil, alfalfa, and biota associated with irrigation drainage in the Uncompahgre Project area and in the Grand Valley, westcentral Colorado, 1991-93: U.S. Geological Survey WaterResources Investigations Report 96-4138, 136 p.

Butler, D.L., and Leib, K.J., 2002, Characterization of selenium in the lower Gunnison River basin, Colorado, 19882000: U.S. Geological Survey Water-Resources Investigation Report 02-4151, 26 p.

California Environmental Protection Agency (CEPA), 2003, 2002 CWA section 303(d) list of water quality limited segment: Colorado River basin Regional Water Quality Control Board, 196 p. (available at URL: http://www.waterboards. ca.gov/tmdl/303d_lists.html)

Carlander, K.D., 1969, Handbook of freshwater fishery biology: Ames, Iowa, Iowa State University Press, 752 p.

Carlander, K.D., 1977, Life history data on centrarchid fishes of the United States and Canada: Ames, Iowa, Iowa State University Press.

Casselman, J.M., 1987, Determination of age and growth, in Weatherly, A.H., and Hill, H.S., eds., The biology of fish growth: London, Academic Press, p. 209-242.

Casselman, J.M., 1990, Growth and relative size of calcified structures of fish: Transactions of the American Fisheries Society, v. 119, p. 673-688.

Chang, S., Zdanowicz, V.S., and Murchelano, R.A., 1998, Associations between liver lesions in winter flounder (Pleuronectes americanus) and sediment chemical contaminants from northeast United States estuaries: ICES Journal of Marine Science, v. 55, p. 954-969.

Chang, C.F., and Chen, M.R., 1990, Fluctuation in sex steroids and sex-binding protein during the development and annual cycle of the male common carp (Cyprinus carpio): Comparative Biochemistry and Physiology Part A, v. 97, no. 4, p. 565-568.

Clark, D.R, and Krynitsky, A.J., 1983, DDT: Recent contamination in New Mexico and Arizona?: Environment, v. 25, p. 27-31.

Colorado Department of Public Health and Environment (CDPHE), 1998, Colorado 1998 303(d) list, (available at URL: http://www.cdphe.state.co.us/op/wqcc/SpecialTopics/ 303(d)/303dlist.pdf).

Colorado Mining Association, 2004, Colorado mining facts, accessed January 12, 2005, (available at URL: http://www. coloradomining.org). 
Cordy, G.E., Rees, J.A., Edmonds, R.J., Gebler, J.B., Wirt, L., Gellenbeck, D.J., and Anning, D.W., 1998, Water-quality assessment of the central Arizona basins, Arizona and northern Mexico - environmental setting and overview of water quality: U.S. Geological Survey, Water-Resources Investigations Report 98-4097, 72 p.

Coughlan, D.J., Baker, B.K., Cloutman, D.G., and Rash, W.M., 1996, Application and modification of the fish health assessment index used for largemouth bass in the Catawba River, North Carolina-South Carolina, in Miranda, L.E., and DeVries, D.R., eds., National Reservoir Fisheries Symposium-Multidimensional Approaches to Reservoir Fisheries Management: Chattanooga, TN: Bethesda, Md., 1995, American Fisheries Society, v. 16, p. 73-84.

Couillard, C.M., and Hodson, P.V., 1996, Pigmented macrophage aggregates: a toxic response in fish exposed to bleached-kraft mill effluent?: Environmental Toxicology and Chemistry, v. 15, p. 1844-1854.

Covey, K., and Beck, D., 2001, Sediment-deposition rates and organic compounds in bottom sediment at four sites in Lake Mead, Nevada, May 1998: U.S. Geological Survey Open File Report 01-282, 34 p.

Cowan, J.H., Shipp, R.L., Bailey IV, H.K., and Haywick, D.W., 1995, Procedure for rapid processing of large otoliths: Transactions of the American Fisheries Society, v. 124, p. 280-282.

Cox, C., 1991, DCPA (Dacthal): Journal of Pesticide Reform, v. 11, p. 17-20.

Coyle, J.J., Buckler, D.R., Ingersoll, C.G., Fairchild, J.F., and May, T.W., 1993, Effects of dietary selenium on the reproductive success of bluegills (Lepomis macrochirus): Environmental Toxicology and Chemistry, v. 12, p. 551-565.

Cross, J.N., 1985, Fin erosion among fishes collected near a California municipal wastewater outfall (1971-1982): Fishery Bulletin, v. 83, p. 195-206.

Cross, J.N., and Hose, J.E., 1988, Evidence for impaired reproduction in white croaker (Genyonemus lineatus) from contaminated areas off southern California: Marine Environmental Research, v. 24, p. 185-188.

Cross, J.N., and Hose, J.E., 1989, Reproductive impairment in two species of fish from contaminated areas off southern California, in Oceans '89: The Global Ocean, Seattle, WA, 1989: New York, N.Y., Institute of Electrical and Electronics Engineers.

Cuerrier, J.P., Keith, J.A., and Stone, E., 1967, Problems with Cuerrier, J.P., Keith, J.A., and Stone, E., 1967, Problems with DDT in fish culture operations: Le Naturaliste Canadien, v. 94, p. 315-320.
Daniels, W.H., and Robinson, E.H., 1986, Protein and energy requirements of juvenile red drum (Sciaenops ocellatus): Aquaculture, v. 53, p. 243-252.

Dansereau, M., Lariviere, N., Tremblay, D.D., and Belanger, D., 1999, Reproductive performance of two generations of female semidomesticated mink fed diets containing organic mercury contaminated freshwater fish: Archives of Environmental Contamination and Toxicology, v. 36, p. 221-226.

Deacon, J.R., and Stephens, V.C., 1998, Trace elements in streambed sediment and fish liver at selected sites in the upper Colorado River basin, Colorado, 1995-96: U.S. Geological Survey Water Resources Investigations Report 98-4124, 19 p.

De Boeck, G., Meeus, W., De Coen, W., and Blust, R., 2004, Tissue-specific $\mathrm{Cu}$ bioaccumulation patterns and differences in sensitivity to waterborne $\mathrm{Cu}$ in three freshwater fish: rainbow trout (Oncorhynchus mykiss), common carp (Cyprinus carpio), and gibel carp (Carassius auratus gibelio): Aquatic Toxicology, v. 70, p. 179-188.

Deér, K.A., Banka, L., Nemcsók, J., and Abrahám, M., 1996, Effects of deltamethrin on hepatic microsomal P450-dependent monooxygenases in carp: Journal of Environmental Science and Health, v. 31B, p. 637-644.

Delahunty, G., and de Vlaming, V.L., 1980, Seasonal relationships of ovary weight, liver weight, and fat stores with body weight in the goldfish, Carassius auratus (L): Journal of Fish Biology, v. 16, p. 5-13.

Denslow, N.D., Chow, M.C., Kroll, K.J., and Green, L., 1999, Vitellogenin as a biomarker of exposure for estrogen or estrogen mimics: Ecotoxicology, v. 8, p. 385-398.

Denton, J.E., and Yousef, M.K., 1976, Body composition and organ weights of rainbow trout, Salmo gairdneri: Journal of Fish Biology, v. 8, no. 6, p. 489-499.

Dethloff, G.M., and Schmitt, C.J., 2000, Condition factor and organo-somatic indices, in Schmitt, C.J. and Dethloff, G.M., eds., Biomonitoring of Environmental Status and Trends (BEST) Program: selected methods for monitoring chemical contaminants in aquatic ecosystems: U.S. Geological Survey, Biological Resources Division, Information and Technology Report 2000-0005, p. 13-17.

de Vlaming, V.L., Grossman, G., and Chapman, F., 1981, On the use of gonadosomatic index: Comparative Biochemistry and Physiology, v. 73A, p. 31-39.

Dietz, R., Nielson, C.O., Hansen, M.M., and Hansen, C.T., 1990, Organic mercury in Greenland birds and mammals: Science of the Total Environment, v. 95, p. 41-51. 
Diniz, M.S., Peres, I., and Pihan, J.C., 2005, Comparative study of the estrogenic responses of mirror carp (Cyprinus carpio) exposed to treated municipal sewage effluent (Lisbon) during two periods in different seasons: Science of the Total Environment, v. 349, p. 129-139.

Donohoe, R.E., and Curtis, L.R., 1996, Estrogenic activity of chlordecone, $o, p$ '-DDT and $o, p$ '-DDE in juvenile rainbow trout: induction of vitellogenesis and interaction with hepatic estrogen binding sites: Aquatic Toxicology, v. 36, p. 31-52.

Down, N.E., Peter, R.E., and Leatherland, J.F., 1990, Seasonal changes in serum gonadotropin, testosterone, 11-ketotestosterone, and estradiol-17 $\beta$ levels and their relation to tumor burden in gonadal tumor-bearing carp $\mathrm{x}$ goldfish hybrids in the Great Lakes: General and Comparative Endocrinology, v. 77, p. 192-201.

Doyon, J.F., Downing, J.A., and Manin, E., 1988, Variation in the condition of northern pike, Esox lucius: Canadian Journal of Fisheries and Aquatic Sciences, v. 45, p. 479-483.

Drevnick, P.E., and Sandheinrich, M.B., 2003, Effects of dietary methylmercury on reproductive endocrinology of fathead minnows: Environmental Science and Technology, v. 37 , no. 19 , p. $4390-4396$.

Dutta, H.M., Misquitta, D., and Khan, S., 2006, The effects of endosulfan on the testes of bluegill fish, Lepomis macrochirus: A histopathological study: Archives of Environmental Contamination and Toxicology, v. 51, p. 149-156.

Eisler, R., 1985, Cadmium hazards to fish, wildlife, and invertebrates: a synoptic review: U.S. Fish and Wildlife Service Biological Report 85(1.2), 46 p.

Eisler, R., 1986, Chromium hazards to fish, wildlife, and invertebrates: a synoptic review: U.S. Fish and Wildlife Service, Biological Report 85(1.6), 60 p.

Eisler, R., 1987, Mercury hazards to fish, wildlife, and invertebrates: a synoptic review: U.S. Fish and Wildlife Service Biological Report 85(1.10), 90 p.

Eisler, R., 1990, Chlordane hazards to fish, wildlife, and invertebrates: a synoptic review: U.S. Fish and Wildlife Service Biological Report 85(1.21), 49 p.

Eisler, R., 1993, Zinc hazards to fish, wildlife, and invertebrates: a synoptic review: U.S. Fish and Wildlife Service Biological Report 10, 106 p.

Eisler, R., 1997, Copper hazards to fish, wildlife, and invertebrates: a synoptic review: U.S. Geological Survey, Biological Resources Division, Biological Science Report 19970002, 98 p.
Eisler, R., and Jacknow, J., 1985, Toxaphene hazards to fish, wildlife, and invertebrates: a synoptic review: U.S. Fish and Wildlife Service Biological Report 85 (1.4), 26 p.

Ellis, A.E., Munro, A.L.S., and Roberts, R.J., 1976, Defense mechanisms in fish. 1. A study of the phagocytic system and the fate of intraperitoneally injected particulate material in the plaice (Pleuronectes platessa L.): Journal of Fish Biology, v. 8, p. 67-78.

Engberg, R.A., 1999, Selenium budgets for Lake Powell and the upper Colorado River basin: Journal of the American Water Resources Association, v. 35, no. 4, p. 771-786.

Fabacher, D.L., and Baumann, P.C., 1985, Enlarged livers and hepatic microsomal mixed-function oxidase components in tumor-bearing brown bullheads from a chemically contaminated river: Environmental Toxicology and Chemistry, v. 4, no. 5 , p. 703-710.

Fairchild, J.F., Allert, A.L., Poulton, B.C., and Graham, R.V., 2002, A site-specific assessment of the impacts of ammonia on endangered fish of the upper Colorado River: Final Report submitted to the U.S. Fish and Wildlife Service, Salt Lake City, UT, 126 p.

Ferguson, H.W., 1976, The relationship between ellipsoids and melano-macrophage centres in the spleen of turbot (Scophthalmus maximus): Journal of Comparative Pathology, v. 86, p. 377-380.

Fernadez, P. and Grimalt, J.O., 2003, On the global distribution of persistent organic pollutants: Chimia, v. 57, p. 514521.

Fine, M., Zilberg, D., Cohen, Z., Degani, G., Moav, B., and Gertler, A., 1996, The effect of dietary protein level, water temperature, and growth hormone administration on growth and metabolism in the common carp (Cyprinus carpio): Comparative Biochemistry and Physiology, v. 114A, p. 35-42.

Fisher, J.P., Fitzsimons, J.D., Combs, G.F., Jr., and Spitsbergen, J.M., 1996, Naturally occurring thiamine deficiency causing reproductive failure in Finger Lakes Atlantic salmon and Great Lakes lake trout: Transactions of the American Fisheries Society, v. 125, no. 2, p. 167-178.

Fjeld, E., Haugen, T.O., and Vollestad, L.A., 1998, Permanent impairment in the feeding behavior of grayling (Thymallus thymallus) exposed to methylmercury during embryogenesis: Science of the Total Environment, v. 213, p. 247-254.

Folmar, L.C., Denslow, N.D., Rao, V., Chow, M., Crain, D.A., Enblom, J., Marcino, J., and Guillette, L.J., Jr., 1996, Vitellogenin induction and reduced serum testosterone concentrations in feral male carp (Cyprinus carpio) captured near a major metropolitan sewage treatment plant: Environmental Health Perspectives, v. 104, no. 10, p. 1096-1101. 
Folmar, L.C., Gardner, G.R., Schreibman, M.P., MagliuloCepriano, L., Mills, L.J., Zaroogian, G., Gutjahr-Gobell, R., Haebler, R., Horowitz, D.B., and Denslow, N.D., 2001, Vitellogenin-induced pathology in male summer flounder (Paralichthys dentatus): Aquatic Toxicology, v. 51, no. 4, p. 431-441.

Folmar, L.C., Hemmer, M., Hemmer, R., Bowman, C., Kroll, K., and Denslow, N.D., 2000, Comparative estrogenicity of estradiol, ethynyl estradiol and diethylsilbestrol in an in vivo, male sheepshead minnow (Cyprinodon variegatus), vitellogenin bioassay: Aquatic Toxicology, v. 49, no. 1/2, p. 77-88.

Förlin, L., and Haux, C., 1990, Sex differences in hepatic cytochrome P-450 monooxygenase activities in rainbow trout during an annual reproductive cycle: Journal of Endocrinology, v. 124, p. 207-213.

Foster, A.R., Houlihan, D.F., and Hall, S.J., 1993, Effects of nutritional regime on correlates of growth rate in juvenile Atlantic cod (Gadhus morhua): comparisons of morphological and biochemical measurements: Canadian Journal of Fisheries and Aquatic Sciences, v. 50, p. 502-512.

Fournie, J.W., Wolffe, M.J., Wolf, J.C., Courtney, L.E., Johnson, R.D., and Hawkins, W.E., 2005, Diagnostic criteria for proliferative thyroid lesions in bony fishes: Toxicologic Pathology, v. 33, p. 540-551.

Fournie, J.W., Summers, J.K., Courtney, L.A., Engle, V.D., and Blazer, V.S., 2001, Utility of splenic macrophage aggregates as an indicator of fish exposure to degraded environments: Journal of Aquatic Animal Health, v. 13, no. 2, p. 105-116.

Fournie, J.W., Summers, J.K., and Weisberg, S.B., 1996, Prevalence of gross pathological abnormalities in estuarine fishes: Transactions of the American Fisheries Society, v. 125 , no. 4 , p. 581-190.

García-Hernández, J., King, K., Velasco, A., Shumilin, E., Mora, M., and Glenn, E., 2001, Selenium, selected inorganic elements, and organochlorine pesticides in bottom material and biota from the Colorado River delta: Journal of Arid Environments, v. 49, p. 65-89.

García-Hernández, J., Sapozhnikova, Y.V., Schlenk, D., Mason, A.Z., Hinojosa-huerta, O., Rivera-Díaz, J.J., RamosDelgado, N.A., 2006, Concentrations of contaminants in breeding bird eggs from the Colorado River delta, Mexico: Environmental Toxicology and Chemistry, v. 25, p. 16401647.

Gebler, J.B., 1998, Water quality of selected effluent-dependent stream reaches in southern Arizona as indicated by concentrations periphytic chlorophyll a and aquaticinvertebrate communities: U.S. Geological Survey Water Resources Investigations Report 98-4199, 18 p.
Gebler, J.B., 2000, Organochlorine compounds in streambed sediment and in biological tissue from streams and their relations to land use, central Arizona: U.S. Geological Survey Water Resources Investigations Report 00-4041, 18 p.

Gellenbeck, D.J., and Anning, D.W., 2002, Occurrence and distribution of pesticides and volatile organic compounds in ground water and surface water in Central Arizona Basins, 1996-98, and their relation to land use: U.S. Geological Survey Water Resources Investigations Report 01-4111, 111 p.

Gernard, J., Messer, J.J., Post, F.J., and Lamarra, V.A., 1983, Assessing the effects of coal mining and related energy development on aquatic environmental quality in the Colorado River basin, in Adams, V.D. and Lamarra, V.A., eds., Aquatic resources management of the Colorado River ecosystem, Ann Arbor, Mich., Ann Arbor Science Publishers, p. 383-397.

Giesy, J.P., Bowerman, W.W., Mora, M.A., Verbrugee, D.A., Othoudt, R.A., Newsted, J.L., Summer, C.L., Aulerich, R.J., Bursian, S.J., Ludwig, J.P., Dawson, G.A., Kubiak, T.J., Best, D.A., and Tillitt, D.E., 1995, Contaminants in fishes from Great Lakes-influenced sections and above dams of three Michigan rivers: III. implications for health of bald eagles: Archives of Environmental Contamination and Toxicology, v. 29, p. 309-321.

Gilderhus, P.A., 1966, Some effects of sublethal concentrations of sodium arsenate on bluegills and the aquatic environment: Transactions of the American Fisheries Society, v. 95, p. 289-296.

Gillespie, R.B., and Baumann, P.C., 1986, Effects of high tissue concentrations of selenium on reproduction by bluegills: Transactions of the American Fisheries Society, v. 115, p. 208-213.

Gimeno, S., Komen, H., Venderbosch, P., and Bowmer, T., 1997, Disruption of sexual differentiation in genetic male common carp (Cyprinus carpio) exposed to an alkylphenol during different life stages: Environmental Science and Technology, v. 31, p. 2884-2890.

Gimeno, S., Komen, H., Gerritsen, A., and Bowmer, T., 1998, Feminization of young males of the common carp, Cyprinus carpio, exposed to 4-tert-pentylphenol during sexual differentiation: Aquatic Toxicology, v. 43, p. 77-92.

Gingerich, W.H., 1982, Hepatic toxicology of fishes, in Weber, L.J., ed., Aquatic toxicology: New York, N.Y., Raven Press, p. 55-105.

Gloss, S.P., Lovich, J.E., and Melis, T.S., eds., 2005, The state of the Colorado River ecosystem in Grand Canyon: U.S. Geological Survey Circular 1282, 220 p. 
Goede, R.W., 1988, Fish health/condition assessment procedures. Part 2 - a color atlas of necropsy classification categories: Utah Division of Wildlife Resources, Fisheries Experiment Station.

Goede, R.W., and Barton, B.A., 1990, Organismic indices and an autopsy-based assessment as indicators of health and condition of fish, in Adams, S.M., ed., Biological indicators of stress in fish, American Fisheries Society symposium 8: Bethesda, Md., p. 93-108.

Goede, R.W, 1996, Fish health/condition assessment procedures. Part 1 - procedure manual: Utah Division of Wildlife Resources, Fisheries Experiment Station, 31 p.

Goleman, W.A., Carr, J.A., and Anderson, T.A., 2002 , Environmentally relevant concentrations of ammonium perchlorate inhibit thyroid function and alter sex ratios in developing Xenopus laevis: Environmental Toxicology and Chemistry, v. 21, p. 590-597.

Goodbred, S.L., Gilliom, R.J., Gross, T.S., Denslow, N.P., Bryant, W.L., and Schoeb, T.R., 1997, Reconnaissance of 17ß-estradiol, 11-ketotestosterone, vitellogenin, and gonad histopathology in common carp of United States streams: potential for contaminant-induced endocrine disruption: U.S. Geological Survey Open-File Report 96-627, 47 p.

Grady, A.W., McLaughlin, R.M., Caldwell, C.W., Schmitt, C.J., and Stalling, D.L., 1992, Flow cytometry, morphometry and histopathology as biomarkers of benzo[a]pyrene exposure in brown bullheads (Ameiurus nebulosus): Journal of Applied Toxicology, v. 12, no. 3, p. 165-177.

Gross, T.S., Wieser, C.M., Sepúlveda, M.S., Wiebe, J.J., Schoeb, T.S., and Denslow, N.D., 2002, Characterization of annual reproductive cycle for pond-reared Florida largemouth bass (Micropterus salmoides): American Fisheries Symposium, v. 31, p. 205-212.

Gross, T., Leiker, T., Goodbred, S., Orsak, E., Weiser, C., and Ruessler, D., 2004, Characterization of exposure to and effects of wastewater effluents in Las Vegas Bay, Lake Mead, Nevada: Presented at Society of Environmental Toxicology and Chemistry $4^{\text {th }}$ World Congress, Portland, Oreg., November 15-19, 2004.

Guillette, L.J., Jr., Gross, T.S., Masson, G.R., Matter, J.M., Percival, H.F., and Woodward, A.R., 1994, Developmental abnormalities of the gonad and abnormal sex hormone concentrations in juvenile alligators from contaminated and control lakes in Florida: Environmental Health Perspectives, v. 102 , p. $680-688$.

Guillette, L.J., Jr., Gross, T.S., Arnold, S.F., and McLachlan, J.A., 1996, Ecoestrogens and embryos - is this a scientific basis for concern?: Animal Reproductive Science, v. 42, p. 13-24.
Hamilton, S., 2004, Review of selenium toxicity in the aquatic food chain: Science of the Total Environment, v. 326, p. $1-31$.

Hamilton, S.J., Holley, K.M., Buhl, K.J., Bullard, F.A., Weston, L.K., and McDonald, S.F., 2005a, Selenium impacts on razorback sucker, Colorado River, Colorado I. Adults: Ecotoxicology and Environmental Safety, v. 61, p. 7-31.

Hamilton, S.J., Holley, K.M., Buhl, K.J., and Bullard, F.A., 2005b, Selenium impacts on razorback sucker, Colorado River, Colorado II. Eggs: Ecotoxicology and Environmental Safety, v. 61, p. 32-43.

Hamilton, S.J., Holley, K.M., Buhl, K.J., and Bullard, F.A., 2005c, Selenium impacts on razorback sucker, Colorado River, Colorado III. Larvae: Ecotoxicology and Environmental Safety, v. 61, p. 168-189.

Handy, R., 2003, Chronic effects of copper exposure versus endocrine toxicity: two sides of the same toxicological process?: Comparative Biochemistry and Physiology A, v. 135 , p. $25-38$.

Hansen, D.J., Schimmel, S.C., and Forester, J., 1973, Aroclor ${ }^{\circledR} 1254$ in eggs of sheepshead minnows: effect on fertilization success and survival of embryos and fry, Proceedings of the $27^{\text {th }}$ Annual Conference of the Southeastern Association of Game and Fish Commissioners.

Hansen, L.G., 1998, Stepping backward to improve assessment of PCB congener toxicities: Environmental Health Perspectives, v. 106, suppl. 1, p. 171-189.

Harbeck, G.E., Kohler, M.A., Jr., and Koberg, G.E., 1958, Water-loss investigations: Lake Mead studies: U.S. Geological Survey Professional Paper No. 298, 100 p.

Hassanin, A., Kuwahara, S., Nurhidayat, Tsukamoto, Y., Ogawa, K., Hirmatsu, K., and Sasaki, F., 2002, Gonadosomatic index and testis morphology of common carp (Cyprinus carpio) in rivers contaminated with estrogenic chemicals: Journal of Veterinary Medicine and Science, v. 64, p. 921-926.

Heaton, S.N., Bursian, S.J., Giesy, J.P., Tillitt, D.E., Render, J.A., Jones, P.D., Verbrugge, D.A., Kubiak, T.J., and Aulerich, R.J., 1995, Dietary exposure of mink to carp from Saginaw Bay, Michigan: 2. Hematology and liver pathology: Archives of Environmental Contamination and Toxicology, v. 29, p. 411-417.

Heinz, G.H., 1979, Methylmercury: reproductive and behavioral effects on three generations of mallard ducks: Journal of Wildlife Management, v. 43, p. 394-401. 
Heinz, G.H., and Hoffman, D.J., 1998, Methylmercury chloride and selenomethionine interactions on health and reproduction in mallards: Environmental Toxicology and Chemistry, v. 17, p. 139-145.

Hermanutz, R.O., Allen, K.N., Roush, T.H., and Hedtke, S., 1992, Effects of elevated selenium concentrations on bluegills (Lepomis macrochirus) in outdoor experimental streams: Environmental Toxicology and Chemistry, v. 11, p. 217-224.

Hesthagen, T., 1985, Validity of the age determination from scales of brown trout (Salmo trutta L.): National Swedish Board of Fisheries, Institute of Freshwater Research Report No. 62, p. 65-70.

Hileman, B., 1994, Environmental estrogens linked to reproductive abnormalities, cancer: Chemical and Engineering News, v. 72, no. 5, p. 19-23.

Hinck, J.E., Schmitt, C.J., Bartish, T.M., Denslow, N.D., Blazer, V.S., Anderson, P.J., Coyle, J.J., Dethloff, G.M., and Tillitt, D.E., 2004a, Biomonitoring of Environmental Status and Trends (BEST) Program: Environmental contaminants and their effects on fish in the Columbia River basin: U.S. Geological Survey Scientific Investigations Report 20045154, 126 p.

Hinck, J.E., Bartish, T.M., Blazer, V.S., Denslow, N.D., Gross, T.S., Myers, M.S., Anderson, P.J., Orazio, C.E., and Tillitt, D.E., 2004b, Biomonitoring of Environmental Status and Trends (BEST) Program: Environmental contaminants and their effects on fish in the Yukon River basin: U.S. Geological Survey Scientific Investigations Report 2004-5285, 87 p.

Hinton, D.E., Baumann, P.C., Gardner, G.R., Hawkins, W.E., Hendricks, J.D., Murchelano, R.A., and Okihiro, M.S., 1992, Histopathologic biomarkers, in Huggett, R.J., Kimerle, R.A., Mehrle, P.M., Jr., and Bergman, H.A., eds., Biomarkers: biochemical, physiological, and histological markers of anthropogenic stress: Chelsea, Mich., Lewis Publishers, p. 155-210.

Hinton, D.E., 1993, Toxicologic histopathology of fishes: a systemic approach and overview, in Couch, J.A., and Fournie, J.W., eds., Pathobiology of marine and estuarine organisms: Boca Raton, Fla., CRC Press.

Holcombe, G.W., Benoit, D.A., Leonard, E.N., and McKim, J.M., 1976, Long-term effects of lead exposure on three generations of brook trout (Salvelinus fontinalis): Journal of Fisheries Research Board of Canada, v. 33, p. 1731-1741.

Holden, P.B., 1979, The ecology of riverine fishes in regulated stream systems with emphasis on the Colorado River, in Ward, J.V. and Stanford, J.A., eds., The ecology of regulated streams: New York, N.Y., Plenum Press, p. 57-74.
Holden, P.B., 2000, San Juan River Recovery Implementation Program Biology Committee Program evaluation report for the 7-year research period (1991-1997): BIO/WEST, Inc. Report PR-646-1, 114 p.

Holden, P.B., and Stalnaker, C.B., 1975, Distribution and abundance of mainstream fishes of the middle and upper Colorado River basins: Transactions of the American Fisheries Society, v. 104, no. 2, p. 217-230.

Hopkins, C.L., Solly, S.R, and Ritchie, A.R., 1969, DDT in trout and its possible effect on reproductive potential: New Zealand Journal of Marine Freshwater Research, v. 3, p. 220-229.

Hornshaw, T.C., Aulerich, R.J., and Johnson, H.E., 1983, Feeding great lakes fish to mink: effects on mink and accumulation and elimination of PCBs by mink: Journal of Toxicology and Environmental Health, v. 11, p. 933-946.

Jarvinen, A.W., and Ankley, G.T., 1999, Linkage of effects to tissue residues: development of a comprehensive database for aquatic organisms exposed to inorganic and organic chemicals: Pensacola, Fla., SETAC Press, 358 p.

Jobling, S., Nolan, M., Tyler, C.R., Brighty, G., and Sumpter, J.P., 1998, Widespread sexual disruption in wild fish: Environmental Science and Technology, v. 32, p. 2498-2506.

Johnson, H.E., and Pecor, C., 1969, Coho salmon mortality and DDT in Lake Michigan, in $34^{\text {th }}$ North American Wildlife Conference: Washington D.C., March 2-5, 1969, p. 159-166.

Johnson, W.L., and Finley, M.T., 1980, Handbook of acute toxicity of chemicals to fish and aquatic invertebrates: summaries of toxicity tests conducted at Columbia National Fisheries Research Lab, 1965-78: U.S. Fish and Wildlife Service Resource Publication 137, 98 p.

Johnson, L.L., Casillas, E., Collier, T.K., McCain, B.B., and Varanasi, U., 1988, Contaminant effects on ovarian development in English sole (Parophyrs vetulus) from Puget Sound, Washington: Canadian Journal of Fisheries and Aquatic Sciences, v. 45, no. 12, p. 2133-2146.

June, F.C., 1970, Atresia and year-class abundance of northern pike, Esox lucius, in two Missouri River impoundments: Journal of Fisheries Research Board of Canada, v. 27, p. 587-591.

June, F.C., 1977, Reproductive patterns in seventeen species of warmwater fishes in a Missouri River reservoir: Environmental Biology of Fishes, v. 2, p. 285-296.

Kaiser, K.L., 1987, The rise and fall of mirex: Environmental Science and Technology, v. 12, p. 520-528. 
Kania, H. J., and O'Hara, J., 1974, Behavioral alterations in a simple predator-prey system due to sublethal exposure to mercury: Transactions of the American Fisheries Society, v. 103, p. 134-136.

Kennedy, S.W., and Jones, S.P., 1994, Simultaneous measurement of cytochrome P4501A catalytic activity and total protein concentration with a fluorescence plate reader: Analytical Biochemistry, v. 222, p. 217-223.

Kepner, W., 1987, Organochlorine contaminant investigation of the lower Gila River, Arizona: U.S. Fish and Wildlife Service Division of Environmental Contaminants. Phoenix, Ariz., 12 p.

Kiceniuk, J.W., and Khan, R.A., 1987, Effect of petroleum hydrocarbons on Atlantic cod, Gadhus morhua, following chronic exposure: Canadian Journal of Zoology, v. 65, p. 490-494.

King, K.A., Baker, L.B., Kepner, W.G., and Martinez, C.T., 1993, Trace elements in sediment and fish from national wildlife refuges on the Colorado River, Arizona: U.S. Fish and Wildlife Service Arizona Ecological Service Office, 14 p.

King, K.A., and Baker, D.L., 1995, Contaminants in fish and wildlife of the middle Gila River, Arizona: U.S. Fish and Wildlife Service, Arizona Ecological Service Office, 12 p.

King, K.A., Andrews, B.J., Martinez, C.T., and Kepner, W.G., 1997, Environmental contaminants in fish and wildlife of the lower Gila River, Arizona: U.S. Fish and Wildlife Service Report 22410-1130-2F30, p. 64.

Kirubagaran, R., and Joy, K.P., 1988, Toxic effects of mercuric chloride, methylmercuric chloride, and emisan 6 (an organic mercurial fungicide) on ovarian recrudescence in the catfish Clarias batrachus (L.): Bulletin of Environmental Contamination and Toxicology, v. 41, p. 902-909.

Kosmala, A., Migeon, B., Flammarion, P., and Garric, J., 1998, Impact assessment of a wastewater treatment plant effluent using a fish biomarker ethoxyresorufin- $O$-deethylase: field and on-site experiments: Ecotoxicology and Environmental Safety, v. 41, p. 19-28.

Kramer, D.A., Papp, J.F., LaTurno, N.M., and Gambogi, J., 1997, Mine and mineral processing plant locations: Supplemental information for USGS map I-2654: U.S. Geological Survey.

Krykhtin, M.L., 1976, Morphological and physiological indicators of the Kaluga sturgeon, Huso dauricus from the Amur Estuary: Journal of Ichthyology, v. 16, p. 259-270.

Lavado, R., Thibaut, R., Raldúa, D., Matín, R., and Porte, C., 2004, First evidence of endocrine disruption in feral carp from the Ebro River: Toxicology and Applied Pharmacology, v. 196, p. 247-257.
Le Guével, R., Petit, F.G., Le Goff, P., Métivier, R., Valotaire, Y., and Pakdel, F., 2000, Inhibition of rainbow trout (Oncorhynchus mykiss) estrogen receptor activity by cadmium: Biology of Reproduction, v. 63, p. 259-266.

Lemly, A.D., 1996, Selenium in aquatic organisms, in Beyer, W.N., Heinz, G.H., and Redmon-Norwood, A.W., eds., Environmental contaminants in wildlife: interpreting tissue concentrations: Boca Raton, Fla., Lewis Publishers, p. 427445 .

Lemly, A.D., 1997, Teratogenic effects of selenium in natural populations of freshwater fish: Ecotoxicology and Environmental Safety, v. 26, p. 181-204.

Lemly, A.D., 2002, Symptoms and implications of selenium toxicity in fish: the Belews Lake case example: Aquatic Toxicology, v. 57, p. 39-49.

Leonard, P.M., and Orth, D.J., 1986, Application and testing of an index of biotic integrity in small, coolwater streams: Transactions of the American Fisheries Society, v. 115, p. 401-414.

Lindesjoo, E., and Thulin, J., 1990, Fin erosion of perch Perca fluviatilis and ruffe Gymnocephalus cernua in a pulp mill effluent: Diseases of Aquatic Organisms, v. 8, p. 119-126.

Liney, K.E., Jobling, S., Shears, J.A., Simpson, P., and Tyler, C.R., 2005, Assessing the sensitivity of different life stages for sexual disruption in roach (Rutilus rutilus) exposed to effluents from wastewater treatment works: Environmental Health Perspectives, v. 113, p. 1299-1307.

Lorenzen, A., and Kennedy, S.W., 1993, A fluorescence-based protein assay for use with a microplate reader: Analytical Biochemistry, v. 214, p. 346-348.

Lower Colorado River Multi-Species Conservation Program, 2005, Lower Colorado River multi-species conservation program handout, accessed May 4, 2005, at URL http:/ www.lcrmscp.org).

Luna, L.G., 1992, Histopathological methods and color atlas of special stains and tissue artifacts: Gaithersburg, Md., American Histolabs, Inc.

Macek, K.J., 1968, Reproduction in brook trout (Salvelinus fontinalis) fed sublethal concentrations of DDT: Journal of Fisheries Research Board of Canada, v. 25, p. 1787-1796.

Macek, K.J., Rodgers, C.R., Stalling, D.L., and Korn, S., 1970, The uptake, distribution and elimination of dietary ${ }^{14} \mathrm{C}$ DDT and ${ }^{14} \mathrm{C}$-Dieldrin in rainbow trout: Transactions of the American Fisheries Society, v. 99, p. 689-695.

Malins, D.C., McCain, B.B., Landahl, J.T., Myers, M.S., and Krahn, M.M., 1988, Neoplastic and other disease in fish in relation to toxic chemicals: an overview: Aquatic Toxicology, v. 11, no. 1/2, p. 43-67. 
Marionnet, D., Taysse, L., Chambras, C., and Deschaux, P., 1997, 3-methylcholanthrene-induced EROD activity and cytochrome $\mathrm{P} 450$ in immune organs of carp (Cyprinus carpio): Comparative Biochemistry and Physiology, v. 118C, p. 165-170.

Marionnet, D., Chambras, C., Taysse, L., Bosgireaud, C., and Deschaux, P., 1998, Modulation of drug-metabolizing systems by bacterial endotoxin in carp liver and immune organs: Ecotoxicology and Environmental Safety, v. 41, p. 189-194.

Matsche, M., and Grizzle, J.M., 1999, Early changes in pigmented macrophages in head kidney of channel catfish infected with Aeromonas hydrophila: Journal of Aquatic Animal Health, v. 11, p. 253-261.

Matta, M.B., Linse, J., Cairncross, C., Francendese, L., and Kocan, R.M., 2001, Reproductive and transgenerational effects of methylmercury or Aroclor 1268 on Fundulus heteroclitus: Environmental Toxicology and Chemistry, v. 20, p. 327-335.

May, T.W., and McKinney, G.L., 1981, Cadmium, mercury, arsenic, and selenium concentrations in freshwater fish, 1976-1977 - National Pesticide Monitoring Program: Pesticide Monitoring Journal, v. 16, p. 41-51.

Mayer, F.L., Jr., Merhle, P.M., Jr., and Dwyer, W.P., 1975, Toxaphene effects on reproduction, growth, and mortality of brook trout, Duluth MN: U.S. Environmental Protection Agency Report EPA-600/3-75/013.

Mayer, F.L., Jr., Mehrle, P.M., and Crutcher, P.L., 1978, Interactions of toxaphene and vitamin $\mathrm{C}$ in channel catfish: Transaction of the American Fisheries Society, v. 107, p. 326-333.

McDonald, M.M., 1991. Toxicity studies of pentachlorobenzene in F344/N rats and B6C3F1 mice. U.S. Department of Health and Human Services, National Institutes of Health, NIH 91-3125, $52 \mathrm{p}$.

McDonald, K.K., Gross, T.S., Denslow, N.D., Densmore, C., and Blazer, V.S., 2002, Reproductive biomarkers, in Biomonitoring of Environmental Status and Trends (BEST) Program: Environmental contaminants and their effects on fish in the Mississippi River basin: U.S. Geological Survey Biological Science Report 2002-0004, p. 135-170.

McGreachy, S.M., and Dixon, D.G., 1990, Effect of temperature on the chronic toxicity of arsenate to rainbow trout (Oncorhynchus mykiss): Canadian Journal of Fisheries and Aquatic Science, v. 47, p. 2228-2234.

McGreachy, S.M., and Dixon, D.G., 1992, Whole-body arsenic concentrations in rainbow trout during acute exposure to arsenate: Ecotoxicology and Environmental Safety, v. 24, p. 301-308.
McKim, J.M., Olson, G.F., Holcombe, G.W., and Hunt, E.P., 1976, Long-term effects on methlymercuric chloride on three generations of brook trout (Salvelinus fontinalis): Toxicity, accumulation, distribution, and elimination: Journal of Fisheries Research Board of Canada, v. 33, p. 2726-2739.

McMaster, M.E., van der Kraak, G.J., Portt, C.B., Munkittrick, K.R., Sibley, P.K., Smith, I.R., and Dixon, D.G., 1991, Changes in hepatic mixed-function oxygenase (MFO) activity, plasma steroid levels and age at maturity of a white sucker (Catostomus commersoni) population exposed to bleached kraft pulp mill effluent: Aquatic Toxicology, v. 21, p. 199-218.

Mehrle, P.M., Haines, T.A., Hamilton, S.J., Ludke, J.L., Mayer, F.L., and Ribick, M.A., 1982, Relationship between body contaminants and bone development in east-coast striped bass: Transactions of the American Fisheries Society, v. 111, p. 231-241.

Melancon, S.M., Michaud, T.S., and Thomas, S.D., 1979, Assessment of energy resource development impact on water quality: the San Juan basin: Interagency EnergyEnvironment Research and Development Program Report USEPA 600/7-79-235.

Metcalfe, T.L., Metcalfe, C.D., Kiparissis, Y., Niimi, A.J., Foran, C.M., and Benson, W.H., 2000, Gonadal development and endocrine responses in Japanese medaka (Oryzias latipes) exposed to $o, p$ '-DDT in water or through maternal transfer: Environmental Toxicology and Chemistry, v. 19, p. 1893-1900.

Miller, P.A., Munkittrick, K.R., and Dixon, D.G., 1992, Relationship between concentrations of copper and zinc in water, sediment, benthic invertebrates, and tissues of white sucker (Catostomus commersoni) at metal-contaminated sites: Canadian Journal of Fisheries and Aquatic Sciences, v. 49, p. 978-984.

Minckley, W.L., 1991, Native fishes of arid lands: A dwindling resource of the desert southwest, USDA Forest Service General Technical Report RM-206, 45 p.

Mize, S.V., and Deacon, J.R., 2002, Relations of benthic invertebrates to concentrations of trace elements in water, streambed sediments, and transplanted bryophytes and stream habitat conditions in nonmining and mining areas of the upper Colorado River basin, Colorado, 1995-98: U.S. Geological Survey Water Resources Investigations Report 02-4139, 58 p.

Möller, H., 1985, A critical review on the role of pollution as a cause of fish diseases, in Ellis, A.E., ed., Fish and shellfish pathology: New York, N.Y., Academic Press, p. 169-182.

Monosson, E., 2000, Reproductive and developmental effects of PCBs in fish: a synthesis of laboratory and field studies: Reviews in Toxicology, v. 3, p. 25-75. 
Moody, C.D., and Mueller, D.K., 1984, Water quality of the Colorado River system: historical trends in the concentration, load, and mass fraction of inorganic solutes: Bureau of Reclamation, Engineering and Research Center Report REC-ERC-84-9, 60 p.

Mora, M.A., García, J., Carpio-Obeso, M., and King, K.A., 2003, Contaminants without borders: A regional assessment of the Colorado River delta ecosystem, in Rapport, D., ed., Managing for Healthy Ecosystems: Boca Raton, Fla., CRC Press, p. 1125-1134.

Mueller, G.A., and Marsh, P.C., 2002, Lost, a desert river and its native fishes: A historical perspective of the lower Colorado River: U.S. Geological Survey Information and Technology Report 2002-0010, 69 p.

Muir, D., Braune, B., DeMarch, D., Norstrom, R., Wagemann, R., Lockhart, L., Hargrave, B., Bright, D., Addison, R., Payne, J., and Reimer, K., 1999, Spatial and temporal trends and effects of contaminants in the Canadian Arctic marine ecosystem: a review: Science of the Total Environment, v. 230, p. 83-144.

Mukhi, S., Carr, J.A., Anderson, T.A., and Patiño, R., 2005, Novel biomarkers of perchlorate exposure in zebrafish: Environmental Toxicology and Chemistry, v. 24, p. 11071115.

Munkittrick, K.R., and Dixon, D.G., 1988, Growth, fecundity, and energy stores of white sucker (Catostomus commersoni) from lakes containing elevated levels of copper and zinc: Canadian Journal of Fisheries and Aquatic Sciences, v. 45, p. 1355-1365.

Murchelano, R.A., and Ziskowski, J., 1982, Fin rot disease in the New York Bight (1973-1977) winter flounder, Pseudopleuronectes americanus, in Mayer, G.F., ed., Ecological stress and the New York Bight: science and management: Columbia, S.C., Estuarine Research Federation, p. 347-358.

Nagahama, Y., 1983, The functional morphology of teleost gonads, in Hoar, W.S., Randall, D.J., and Donaldson, E.M., eds., Fish physiology, vol IX: Orlando, Fla., Academic Press, Inc., p. 223-264.

National Research Council, 2005, Health implications of perchlorate ingestion: Washington, D.C., National Research Council of the National Academies, $177 \mathrm{p}$.

National Research Council of Canada (NRCC), 1982, Chlorinated phenols: criteria for environmental quality. Associated Committee on Scientific Criteria for Environmental Quality. Subcommittee on Pesticides and Industrial Organic Chemicals and Subcommittee on Water, Ottawa, Ontario, Canada.
Nevada Division of Environmental Protection, 2002, Nevada's 2002 303(d) impaired waters list: Nevada Division of Environmental Protection, Bureau of Water Quality Planning, 65 p.

Newell, A.J., Johnson, D.W., and Allen, L.K., 1987, Niagara River biota contamination project: fish flesh criteria for piscivorous wildlife: New York State Department of Environmental Conservation, Division of Fish and Wildlife, Bureau of Environmental Protection Technical Report 87-3, $182 \mathrm{p}$.

New Mexico Environment Department (NMED), 2000, State of New Mexico 303(d) list for assessed stream and river reaches, (available at URL: http://www.nmen.state.nm.us/ swqb/2000-2002-New_Mexico_303d_List.pdf), 44 p.

New Mexico Energy, Minerals, and Natural Resources Department (NMRD), 2003, New Mexico's natural resources: Data and statistics for 2002: New Mexico Energy, Minerals, and Natural Resources Department, $60 \mathrm{p}$.

Niemuth, N., 2004, Arizona mining update - 2002 and 2003: Arizona Department of Mines and Mineral Resources Circular 108, $10 \mathrm{p}$.

Niimi, A.J., 1996, PCBs in aquatic organisms, in Beyer, W.N., Heinz, G.H., and Redmon-Norwood, A.W., eds., Environmental contaminants in wildlife: interpreting tissue concentrations: Boca Raton, Fla., Lewis Publishers, p. 49-72.

Nosek, J.A., Craven, S.R., Sullivan, J.R., Hurley, S.S., and Peterson, R.E., 1992, Toxicity and reproductive effects of 2,3,7,8-tetrachlorodibenzo- $p$-dioxin in ring-necked pheasant hens: Journal of Toxicology and Environmental Health, v. 35, p. 187-198.

Nowell, L.H., Capel, P.D., and Dileanis, P.D., 1999, Pesticides in stream sediment and aquatic biota: Distribution, trends, and governing factors. Lewis Publishers, Boca Raton, Fla., $1001 \mathrm{p}$.

Oakes, K.D., McMaster, M.E., and Van der Kraak, G.J., 2004, Oxidative stress responses in longnose sucker (Catostomus catostomus) exposed to pulp and paper mill and municipal sewage effluents: Aquatic Toxicology, v. 67, p. 255-271.

O'Donnell, M., 1997, Land-use trends in the southwestern United States, in Impact of climate change and land use in the southwestern United States workshop: July 7-25, 1997, $5 \mathrm{p}$.

Ortiz, J.B., González de Canales, M.L., and Sarasquete, C., 2003, Histopathological changes induced by lindane $(\gamma-$ $\mathrm{HCH}$ ) in various organs of fishes: Scientia Marina, v. 67, p. 53-61. 
Osmundson, B., May, T., and Osmundson, D., 2000, Selenium concentrations in the Colorado pikeminnow (Ptychocheilus lucius): relationship with flows in the upper Colorado River: Archives of Environmental Contamination and Toxicology, v. 38 , p. $479-485$.

Owens, S., Eden, C., Guenther, H., and Butler, D., 2004, Perchlorate in Arizona: Occurrence study of 2004: Perchlorate Task Force, 79 p.

Papoulias, D. M., Villalobos, S.A., Meadows, J., Notlie, D.B., Giesy, J.P., and Tillitt, D.E., 2003, In ovo exposure to o, p'DDE affects sexual development but not sexual differentiation in Japanese medaka (Oryzias latipes): Environmental Health Perspectives, v. 111, p. 29-32.

Patiño, R., Wainscott, M.R., Cruz-Li, E.I., Balakkrishnan, S., McMurry, C., Blazer, V.S., and Anderson, T.A., 2003a, Effects of ammonium perchlorate on the reproductive performance and thyroid follicle histology of zebrafish: Environmental Toxicology and Chemistry, v. 22, p. 1115-1121.

Patiño, R., Goodbred, S., Draugelis-Dale, R., Barry, C., Foott, J., Wainscott, M., Gross, T., and Covay, T., 2003b, Morphometric and histopathological parameters of gonadal development in adult common carp from contaminated and reference sites in Lake Mead, Nevada: Journal of Aquatic Animal Health, v. 15, p. 55-68.

Patrick, R., 2000, Rivers of the United States, Part A: The Colorado River, Vol. 5, New York, N.Y., John Wiley and Sons, Inc., 252 p.

Paulson, L.J., and Baker, J.R., 1983, The limnology in reservoirs on the Colorado River: University of Nevada, Department of Biological Sciences, Lake Mead Limnological Research Center Technical Report No. 11, 267 p.

Payne, J.F., Kiceniuk, J.W., Squires, W.R., and Fletcher, G.L., 1978, Pathological changes in marine fish after a 6-month exposure to petroleum: Journal of Fisheries Research Board of Cananda, v. 35, p. 665-667.

Peakall, D.B., 1996, Dieldrin and other cyclodiene pesticides in wildlife, in Beyer, W.N., Heinz, G.H., and Redmon-Norwood, A.W., eds., Environmental contaminants in wildlife: interpreting tissue concentrations: Boca Raton, Fla., Lewis Publishers, p. 73-98.

Perry, M.J., and Mackun, P.J., 2001, Population change and distribution: Census 2000 brief: U.S. Census Bureau Report C2KBR/01-2, 7 p.

Pohl, R.J., and Fouts, J.R., 1980, A rapid method for assaying the metabolism of 7-ethoxyresorufin by microsomal subcellular fractions: Analytical Biochemistry, v. 107, p. 150-155.
Presser, T.S., Sylvester, M.A., and Low, W.H., 1994, Bioaccumulation of selenium from natural geologic sources in western states and its potential consequences: Environmental Management, v. 18, p. 423-436.

Pulsford, A.L., Thomas, M.E., Lemaire-Gony, S., Coles, J., Fossato, V.U., and Pipe, R.K., 1995, Studies on the immune system of the goby, Zosterisessor ophiocephalus, from the Venice Lagoon: Marine Pollution Bulletin, v. 30, p. 586-91.

Radtke, D., Kepner, W., and Effertz, R., 1988, Reconnaissance investigation of water quality, bottom sediment, and biota associated with irrigation drainage in the lower Colorado River valley, Arizona, California, and Nevada, 1986-87: U.S. Geological Survey Water-Resources Investigation Report 88-4002.

Reash, R.J., and Berra, T.M., 1989, Incidence of fin erosion and anomalous fishes in a polluted stream and a nearby clean stream: Water Air and Soil Pollution, v. 47, no. 1-2, p. 47-63.

Reynolds, J.B., 1983, Electrofishing, in Nielsen, L.A., and Johnson, D.L., eds., Fisheries Techniques: Bethesda, Md., American Fisheries Society, p. 147-163.

Rodriguez, J.N., Oteme, Z.J., and Hem, S., 1995, Comparative study of vitellogenesis of two African catfish species Chrysichthys nigrodigitatus (Claroteidae) and Heterobranchus longifilis (Clariidae): Aquatic Living Resources, v. 8, p. 291-296.

Rowland, R., Allen, D., Stephens, D., Darnell, N., and Waddell, B., 2002, Hydrologic, sediment, and biological data associated with irrigation drainage in the middle Green River basin, Utah and Colorado, water years 1991-2000: U.S. Geological Survey Open File Report 02-343.

Ruklov, F.N., 1979, A description of some morphophysiological characters of salmon of the genus Oncorhynchus: Journal of Ichthyology, v. 19, p. 23-40.

Sanderson, J.T., and van den Berg, M., 1999, Toxic equivalency factors (TEFs) and their use in ecological risk assessment: A successful method when used appropriately: Human and Ecological Risk Assessment, v. 5, no. 1, p. 4358.

Scheuhammer, A.W., Wong, A.H., and Bond, D., 1998, Mercury and selenium accumulation in common loons (Gavia immer) and common mergansers (Mergus merganser) from eastern Canada: Environmental Toxicology and Chemistry, v. 17, p. 197-201.

Schimmel, S.C., Hansen, D.J., and Forrester, J., 1974, Effects of Aroclor ${ }^{\circledR} 1254$ on laboratory-reared embryos and fry of sheepshead minnows (Cyprinodon variegates): Transactions of American Fisheries Society, v. 103, p. 582-586. 
Schlenk, D., Perkins, E.J., Hamilton, G., Zhang, Y.S., and Layher, W., 1996, Correlation of hepatic biomarkers with whole animal and population-community metrics: Canadian Journal of Fisheries and Aquatic Sciences, v. 53, p. 22992309.

Schmitt, C.J., and Winger, P.V., 1980, Factors controlling the fate of pesticides in rural watersheds of the lower Mississippi River alluvial valley, in Transactions of the North American Wildlife and Natural Resources Conference, v. 45, p. 354-375.

Schmitt, C.J., 1998, Environmental contaminants, in Mac, M.J., Opler, P.A., Puckett Haecker, C.E., and Doran, P.D., eds., Status and trends of the nation's biological resources, volume 1: U.S. Geological Survey, p. 131-165.

Schmitt, C.J., and Dethloff, G.M., eds., 2000, Biomonitoring of Environmental Status and Trends (BEST) program: Selected methods for monitoring chemical contaminants and their effects in aquatic ecosystems: U.S. Geological Survey Information and Technology Report 2000-0005, 81 p.

Schmitt, C.J., Zajicek, J.L., May, T.W., and Cowman, D.F., 1999, Organochlorine residues and elemental contaminants in U.S. freshwater fish, 1976-1986: National Contaminant Biomonitoring Program: Reviews of Environmental Contamination and Toxicology, v. 162, p. 43-104.

Schmitt, C.J., ed., 2002, Biomonitoring of Environmental Status and Trends (BEST) Program: environmental contaminants and their effects on fish in the Mississippi River basin: U.S. Geological Survey Biological Science Report 2002-0004, $241 \mathrm{p}$.

Schmitt, C.J., Tillitt, D.E., and Whyte, J.J., 2002, Accumulative contaminants, dioxin-equivalent concentrations by H4IIE bioassay, and ethoxyresorufin $O$-deethylase (EROD) activity, in Biomonitoring of Environmental Status and Trends (BEST) Program: environmental contaminants and their effects on fish in the Mississippi River basin: U.S. Geological Survey Biological Science Report 2002-0004, p. 27-88.

Schmitt, C.J., Dethloff, G.M., Hinck, J.E., Bartish, T.M., Blazer, V.S., Coyle, J.J., Denslow, N.D., and Tillitt, D.E., 2004, Biomonitoring of Environmental Status and Trends (BEST) Program: Environmental contaminants and their effects on fish in the Rio Grande basin: U.S. Geological Survey, Scientific Investigations Report 2004-5108, 117 p.

Schrank, C.S., Cormier, S.M, and Blazer, V.S., 1997, Contaminant exposure, biochemical, and histopathological biomarkers in white suckers from contaminated and references sites in the Sheboygan River, Wisconsin: Journal of Great Lakes Research, v. 23, p. 119-130.
Schultz, R., and Hermanutz, R., 1990, Transfer of toxic concentrations of selenium from parent to progeny in the fathead minnow (Pimephales promelas): Bulletin of Environmental Contamination and Toxicology, v. 45, p. 568-573.

Seiler, R.L., Skorupa, J.P., and Peltz, L.A., 1999, Areas susceptible to irrigation-induced selenium contamination of water and biota in the western United States: U.S. Geological Survey Circular 1180, 36 p.

Sepúlveda, M.S., Quinn, B.P., Denslow, N.D., Holm, S.E., and Gross, T.S., 2003, Effects of pulp and paper mill effluents on reproductive success of largemouth bass: Environmental Toxicology and Chemistry, v. 22, p. 205-213.

Sepúlveda, M.S., Ruessler, D.S., Denslow, N.D., Holm, S.E., Schoeb, T.R., and Gross, T.S., 2001, Assessment of reproductive effects in largemouth bass (Micropterus salmoides) exposed to bleached/unbleached kraft mill effluents: Archives of Environmental Contamination and Toxicology, v. 41, p. $475-482$.

Servos, M.R., 1999, Review of the aquatic toxicity, estrogenic responses and bioaccumulation of alkylphenols and alkylphenol polyethoxylates: Water Quality Research Journal of Canada, v. 34, p. 123-177.

Shubat, P.J., and Curtis, L.R., 1986, Ration and toxicant preexposure influence dieldrin accumulation by rainbow trout (Salmo gairdneri): Environmental Toxicology and Chemistry, v. 5, p. 69-77.

Shukla, L., and Pandey, A.K., 1986, Effects of endosulphan on the hypothalamo-hypophysial complex and fish reproductive physiology: Bulletin of Environmental Contamination and Toxicology, v. 26, p. 122-131.

Snarksi, V.M., and Olson, G.F., 1982, Chronic toxicity and bioaccumulation of mercuric chloride in the fathead minnow (Pimephales promelas): Aquatic Toxicology, v. 2, p. 143-156.

Snyder, E.M., Snyder, S.A., Kelly, K.L., Gross, T.S., Villeneuve, D.L., Fitzgerald, S.D., Villalobos, S.A., and Geisy, J.P., 2004, Reproductive responses of common carp (Cyprinus carpio) exposed in cages to influent of the Las Vegas Wash, Nevada, from late winter to early spring: Environmental Science and Technology, v. 38, p. 6385-6395.

So, Y.P., Idler, D.R., Wilson, C.E., and Crim, L.W., 1989, Seasonal variation of plasma vitellogenin and steroid levels in captive female Atlantic salmon kelt, and their changes under re-maturation treatment of testosterone: Bulletin of the Aquaculture Association of Canada, v. 89, p. 31. 
Solé, M., Porte, C., and Barceló, D., 2000, Vitellogenin induction and other biochemical responses in carp, Cyprinus carpio, after experimental injection with $17 \alpha$-ethynylestradiol: Archives of Environmental Contamination and Toxicology, v. 38 , p. $494-500$.

Sorenson, E., 1988, Selenium accumulation, reproductive status, and histopathological changes in environmentally exposed redear sunfish: Archives of Toxicology, v. 61, p. 324-329.

Sorenson, E., Cumbie, P.M., Bauer, T.L., Bell, J.S., and Harlan, C.W., 1984, Histopathological, hematological, condition-factor, and organ weight changes associated with selenium accumulation in dish from Belews Lake, North Carolina: Archives of Environmental Contamination and Toxicology, v. 13, p. 153-162.

Spahr, N.E., Apodaca, L.E., Deacon, J.R., Bails, J.B., Bauch, N.J., Smith, C.M., and Driver, N.E., 2000, Water quality in the upper Colorado River basin, Colorado, 1996-98: U.S. Geological Survey Circular 1214, 33 p.

Spofford, W.O., 1980, Potential impacts of energy development on stream-flows in the upper Colorado River basin, in Spofford, W.O., Parker, A.L., and Kneese, A.V., eds., Energy development in the southwest, 1: Washington D.C., Resources for the Future, Inc., p. 351-429.

Stanford, J.A., and Ward, J.V., 1986, The Colorado River system, in Davies, B.R., and Walker, K.F., eds., The Ecology of River Systems: Dordrecht, The Netherlands, Dr. W. Junk Publishers, p. 353-374.

Starnes, W.C., 1995, Colorado River basin fishes, in LaRoe, E.T., Farris, G.S., Puckett, C.E., Doran, P.D., and Mac, M.J., eds., Our living resources: a report to the nation on the distribution, abundance, and health of U.S. plants, animals, and ecosystems: Washington, D.C., National Biological Service, p. $149-152$.

Stephens, D.W., Waddell, B., Peltz, L.A., and Miller, J.B., 1992, Detailed study of selenium and selected elements in water, bottom sediment, and biota associated with irrigation drainage in the middle Green River basin, Utah, 1988-90: U.S. Geological Survey Water Resources Investigations Report 92-4084, 164 p.

Stephens, D., Waddell, B., and Miller, J., 1988, Reconnaissance investigation of water quality, bottom sediment, and biota associated with irrigation drainage in the middle Green River basin, Utah, 1986-1987: U.S. Geological Survey Water Resources Investigations Report 88-4011.

Summers, J.K., Macauley, J.M., Heitmuller, P.T., Engle, V.D., Adams, A.M., and Brooks, G.T., 1993, Statistical summary: EMAP-estuaries Lousianain Province-1991: U.S. Environmental Protection Agency, Office of Research and Development, EPA/620/R-93/007; PB94-117488, 101 p.
Sun, L., and Jeng, S., 1998, Comparative zinc concentrations in tissues of common carp and other aquatic organisms: Zoological Studies, v. 37, p. 184-190.

Tao, Y., Berlinsky, D.L., and Sullivan, C.V., 1996, Characterization of a vitellogenin receptor in white perch (Morone americana): Biology of Reproduction, v. 55, no. 3, p. 646656.

Taysse, L., Chambras, C., Marionnet, D., Bosgiraud, C., and Deschaux, P., 1998, Basal level and induction of Cytochrome P450, EROD, UDPGT, and GST activities in carp (Cyprinus carpio) immune organs (spleen and head kidney): Bulletin for Environmental Contamination and Toxicology, v. 60 , p. $300-305$.

Tewalt, S.J., Bragg, L.J., and Finkelman, R.B., 2001, Mercury in U.S. coal - abundance, distribution, and modes of occurrence: U.S. Geological Survey Fact Sheet FS-95-01, 4 p.

Thompson, D.R., 1996, Mercury in birds and terrestrial mammals, in Beyer, W.N., Heinz, G.H., and Redmon-Norwood, A.W., eds., Environmental contaminants in wildlife: interpreting tissue concentrations: Boca Raton, Fla., Lewis Publishers, p. 341-356.

Tillitt, D.E., Giesy, J.P., and Ankley, G.T., 1991, Characterization of the H4IIE rat hepatoma cell bioassay as a tool for assessing toxic potency of planar halogenated hydrocarbons in environmental samples: Environmental Science \& Technology, v. 25, no. 1, p. 87-92.

Tillitt, D.E., Gale, R.W., Meadows, J.C., Zajicek, J.L., Peterman, P.H., Heaton, S.N., Jones, P.D., Bursian, S.J., Kubiak, T.J., Giesy, J.P., and Aulerich, R.J., 1996, Dietary exposure of mink to carp from Saginaw Bay 3, characterization of dietary exposure to planar halogenated hydrocarbons, dioxin equivalents, and biomagnification: Environmental Science \& Technology, v. 30, no. 1, p. 283-291.

Tollefsen, K.E., 2002, Interaction of estrogen mimics, singly and in combination, with plasma sex steroid-binding proteins in rainbow trout (Oncorhynchus mykiss): Aquatic Toxicology, v. 56, p. 215-225.

Toppari, J., Larsen, J., Christiansen, P., Giwercman, A., Grandjean, P., Guillette, L.J., Jr., Jegou, B., Jensen, T.K., Jouannet, P., Keiding, N., Leffers, H., McLachlan, J.A., Meyer, O., Muller, J., Rajpert-De Meyts, J., Scheike, T., Sharpe, R., Sumpter, J., and Skakkebaek, N.E., 1996, Male reproductive health and environmental xenoestrogens: Environmental Health Perspectives, v. 104. p. 741-803.

Treasurer, J.W., and Holliday, F.G.T., 1981, Some aspects of the reproductive biology of perch Perca flaviatilis L.: A histological description of the reproductive cycle: Journal of Fish Biology, v. 18, p. 359-376. 
Trueman, D.P., 1998, Colorado River basin Salinity Control Program, 1998 Review, USCID Conference on Shared Rivers, Park City, Utah, October 28-31.

Turk, J.T., and Campbell, D.H., 1997, Are aquatic resources of the Mt. Zirkel Wilderness Area in Colorado affected by acid deposition and what will emissions reductions at the local power plants do?: U.S. Geological Survey Fact Sheet FS-043097, 4 p.

Tuttle, P.L., and Orsak, E.L., 2002, Las Vegas Wash water quality and implications to fish and wildlife: Nevada Fish and Wildlife Office FFS Report 1F27 and 1F31, 52 p.

Tyler, A.V., and Dunn, R.S., 1976, Ration, growth, and measures of somatic and organ condition in relation to meal frequency in winter flounder, Pseudopleuronectes americanus, with hypotheses regarding population homeostasis: Journal of the Fisheries Research Board of Canada, v. 33, p. 63-75.

Tyler, C.R., Jobling, S., and Sumpter, J.P., 1998, Endocrine disruption in wildlife: A critical review of the evidence: Critical Reviews in Toxicology, v. 28, p. 319-361.

Ungerer, J.R., and Thomas, P., 1996, Role of very low density lipoproteins in the accumulation of $o, p^{\prime}$-DDT in fish ovaries during gonadal recrudescence: Aquatic Toxicology, v. 35, p. 183-195.

Upper Colorado River Endangered Fish Recovery Program (UFRP), 2005, Upper Colorado River Endangered Fish Recovery Program, accessed May 4, 2005, at URL (http:// coloradoriverrecovery.fws.gov/).

Urbansky, E.T., 2002, Perchlorate as an environmental contaminant: Environmental Science and Pollution Research, v. 9, p. 187-192.

U.S. Department of Energy, 2005, Remediation of the Moab Uranium Mill Tailings, Grand and San Juan Counties, Utah, Final Environmental Impact Statement: U.S. Department of Energy, Environmental Management Program, DOE/ EIS-0355, 70 p.

U.S. Department of the Interior, 1997, National atlas of the United States: U.S. Department of the Interior, accessed January 11, 2005, at URL (http://nationalatlas.gov/).

U.S. Department of the Interior, 2001, Quality of water in the Colorado River basin: U.S. Department of the Interior Progress Report No. 20, 87 p.

U.S. Environmental Protection Agency (USEPA), 1977, Heavy metal pollution from spillage at ore smelters and mills: USEPA Report EPA-900-2-77-171, 109 p.

U.S. Environmental Protection Agency (USEPA), 1984, Ambient water quality criteria for arsenic: USEPA Report EPA/440/5-84-037.
U.S. Environmental Protection Agency (USEPA), 2002, Reregistration Eligibility Decision for Endosulfan: USEPA Report EPA-738-R-02-013, 224 p.

U.S. Environmental Protection Agency (USEPA), 2004a, National Listing of Fish Advisory query tool: USEPA, accessed January 20, 2005, at URL (http://www.epa.gov/ waterscience/fish/).

U.S. Environmental Protection Agency (USEPA), 2004b, Water Discharge Permits (PCS) query tool: USEPA, accessed January 20, 2005, at URL (http://www.epa.gov/ enviro/html/pcs/pcs_query_java.html).

U.S. Environmental Protection Agency (USEPA), 2004c, CERCLIS hazardous wastes sites: USEPA, accessed January 20, 2005, at URL (http://www.epa.gov/superfund/sites/ index.htm).

U.S. Environmental Protection Agency (USEPA), 2004d, Perchlorate monitoring results Henderson, Nevada to the lower Colorado River: USEPA, Waste Management Division June 2004 Report, 20 p.

U.S. Environmental Protection Agency (USEPA), 2004e, Toxic Release Inventory (TRI) query tool: USEPA, accessed January 20, 2005, at URL http://www.epa.gov/enviro/htmld tris/reports/tri_batch_reports.htm $)$.

U.S. Geological Survey (USGS), 2003, NAWQA Pesticide national Synthesis Project, Sacramento, California, at URL (http://ca.water.usgs.gov/pnsp/).

U.S. Geological Survey (USGS), 2006, National Water Information System, at URL (http://nwis.waterdata.usgs. gov/nwis).

Utah Department of Environmental Quality (UDEQ), 2000, Utah's 2000 303(d) list of waters: Utah Department of Environmental Quality, Division of Water Quality, at URL (http://www.waterquality.utah.gov/documents/approved_ 2000_303d.pdf), 82 p.

van den Berg, M., Birnbaum, L., Bosveld, B.T.C., 1998, Toxic equivalency factors (TEFs) for PCBs, PCDDs, PCDFs for humans and wildlife: Environmental Health Perspectives, v. 106, p. 775-792.

van den Heuvel, M.R., Munkittrick, K.R., van der Kraak, G.J., Servos, M.R., and Dixon, D.G., 1995, Hepatic 7-ethoxyresorufin- $O$-deethylase activity, plasma steroid hormone concentrations, and liver bioassay-derived 2,3,7,8-TCDD toxic equivalent concentrations in wild white sucker (Catostomus commersoni) caged in bleached kraft pulp mill effluent: Canadian Journal of Fisheries and Aquatic Sciences, v. 52, no. 7, p. 1339-1350. 
Versonnen, B.J., Roose, P., Monteyne, E.M., and Janssen, C.R., 2004, Estrogenic and toxic effects of methoxychlor on zebrafish (Danio rerio): Environmental Toxicology and Chemistry, v. 23, p. 2194-2201.

Vilizzi, L., and Walker, K.F., 1999, Age and growth of the common carp, Cyprinus carpio, in the River Murray, Australia: validation, consistency of age interpretation, and growth models: Environmental Biology of Fishes, v. 54, p. 77-106.

Villanueva, E.C., Jennings, R.W., Burse, V.W., and Kimbrough, R.D., 1974, Evidence of chlorobenzo- $p$-dioxin and chlorobenzofurans in hexachlorobenzene: Agricultural and Food Chemistry, v. 22, p. 916-917.

Vogelbein, W.K., Fournie, J.W., Van Veld, P.A., and Huggett, R.J., 1990, Hepatic neoplasms in the mummichog Fundulus heteroclitus from a creosote-contaminated site: Cancer Research, v. 50, no. 18 , p. 5978-5986.

Walker, M.A., Cook, P.M., Butterworth, B.C., Zabel, E.W., and Peterson, R.E., 1996, Potency of a complex mixture of polychlorinated dibenzo- $p$-dioxin, dibenzofuran, and biphenyl congeners compared 2,3,7,8-tetrachlorodibenzo- $p$ dioxin in causing fish early life stage mortality: Fundamental and Applied Toxicology, v. 30, p. 178-187.

Welsh, D., and Maughan, O.E., 1994, Concentrations of selenium in biota, sediments, and water at Cibola National Wildlife Refuge: Archives of Environmental Contamination and Toxicology, v. 26, p. 452-458.

White, A., and Fletcher, T.C., 1985, Seasonal changes in serum glucose and condition of the plaice, Pleuronectes platessa (L): Journal of Fish Biology, v. 26, p. 755-764.

Whyte, J.J., Jung, R.E., Schmitt, C.J., and Tillitt, D.E., 2000, Ethoxyresorufin $O$-deethylase (EROD) activity in fish as a biomarker of chemical exposure: Critical Reviews in Toxicology, v. 30, no. 4, p. 347-570.

Whyte, J.J., Schmitt, C.J., and Tillitt, D.E., 2004, The H4IIE cell bioassay as an indicator of dioxin-like chemicals in wildlife and the environment: Critical Reviews in Toxicology, v. 34, no.1, p.1-83.

Wiener, J.G., and Spry, D.J., 1996, Toxicological significance of mercury in freshwater fish, in Beyer, W.N., Heinz, G.H., and Redmon-Norwood, A.W., eds., Environmental contaminants in wildlife: interpreting tissue concentrations: Boca Raton, Fla., Lewis Publishers, p. 297-339.

Wiener, J.G., Krabbenhoft, D.P, Heinz, G.H., Scheuhammer, A.M., 2002, Ecotoxicology of mercury, in Hoffman, D.J., Rattner, B.A., Burton, G.A., Jr., and Cairns, J., Jr., eds., Handbook of ecotoxicology (2d ed): Boca Raton, Fla., CRC Press, p. 407-461.
Wilde, G., and Pope, K., 2002, Development of an age-structured population model for common carp in Lake Mead, Arizona-Nevada, Final Report: Texas Tech University, Wildlife and Fisheries Management Institute, 26 p.

Wobeser, G.A., Nielson, N.O., and Scheifer, B., 1976, Mercury in mink. II. Experimental methyl mercury intoxication: Canadian Journal of Comparative Medicine, v. 40, p. 34-45.

Wolfe, M.F., Schwartzbach, S., and Sulaiman, R.A., 1998, Effects of mercury on wildlife: a comprehensive review: Environmental Toxicology and Chemistry, v. 17, no. 2, p. 146-160.

Wolff, J., 1998, Perchlorate and the thyroid gland: Pharmacological Reviews, v. 50, no. 1, p. 89-105.

Wolke, R.E., 1992, Piscine macrophage aggregates: a review: Annual Review of Fish Diseases, v. 2, p. 91-108.

Wolke, R.E., Murchelano, R.A., Dickstein, C.D., and George, C.J., 1985, Preliminary evaluation of the use of macrophage aggregates (MA) as fish health monitors: Bulletin of Environmental Contamination and Toxicology, v. 35, p. 222-227.

World Bank Group, 1998, Copper Smelting, in Pollution Prevention and Abatement Handbook, Washington, D.C., p. 291-294.

Wren, C.D., Hunter, D.B., Leatherland, J.F., and Stokes, P.M., 1987, The effects of polychlorinated biphenyls and methylmercury, singly and in combination, on mink. I: Uptake and toxic responses: Archives of Environmental Contamination and Toxicology, v. 16, p. 441-447.

Wyoming Department of Environmental Quality (WDEQ), 2002, Wyoming's 2002 303(d) list of waters requiring TMDLs: Wyoming Department of Environmental Quality, at URL (http://deq.state.wy.us/wqd/watershed/downloads/ TMDL/2-2227.doc.pdf ), 13 p.

Yeardley, R.B., Jr., Lazorchak, J.M., and Paulsen, S.G., 1998, Elemental fish tissue contamination in northeastern U.S. lakes: evaluation of an approach to regional assessment: Environmental Toxicology and Chemistry, v. 17, p. 18751884. 


\section{Appendices}


Appendix 1. Selected species within the Colorado River Basin identified as having special status by the USFWS. aUSFWS Threatened and Endangered Species System (TESS) webpage (https://ecos/fws/gov/ecos/sec/species.dd) accessed 8/23/04.

\begin{tabular}{|c|c|c|}
\hline Common name & Scientific name & Designation $^{a}$ \\
\hline American bittern & Botarurus lentiginosus & Sensitive \\
\hline Colorado River toad & Bufo alvarius & Sensitive \\
\hline Western toad & Bufo boreas & Sensitive \\
\hline Southwestern toad & Bufo microscaphus & Sensitive \\
\hline June sucker & Chasmistes liorus & Endangered \\
\hline Trumpeter swan & Cygnus buccinator & Sensitive \\
\hline Beautiful shiner & Cyprinella formosa & Threatened \\
\hline Desert pupfish & Cyprinodon macularius & Endangered \\
\hline Humpback chub & Gila cypha & Endangered \\
\hline Sonora chub & Gila ditaenia & Threatened \\
\hline Bonytail chub & Gila elegans & Endangered \\
\hline Chihuahua chub & Gila nigrescenas & Threatened \\
\hline Yaqui chub & Gila purpurea & Endangered \\
\hline Virgin River chub & Gila seminuda & Endangered \\
\hline Whooping crane & Grus americana & Endangered \\
\hline Bald eagle & Haliaeetus leucocephalus & Threatened \\
\hline Harlequin duck & Histrionicus histrionicus & Sensitive \\
\hline Yaqui catfish & Ictaturus pricel & Endangered \\
\hline Little Colorado spinedace & Lepidomeda vittata & Threatened \\
\hline River otter & Lontra canadensis & Sensitive \\
\hline Spikedace & Meda fulgida & Threatened \\
\hline Hornyhead chub & Nocomis biguttatus & Sensitive \\
\hline Apache trout & Oncorhynchus apache & Threatened \\
\hline Gila trout & Oncorhynchus gilae & Endangered \\
\hline Kanab ambersnail & Oxyfoma haydeni kanabensis & Endangered \\
\hline Woundfin & Plagopterus argentissimus & Endangered \\
\hline Gila topminnow & Poeciliopsis occidentalis & Endangered \\
\hline Colorado pikeminnow & Ptychocheilus lucius & Endangered \\
\hline Yuma clapper rail & Rallus longirostris yumanensis & Endangered \\
\hline Chiricahua leopard frog & Rana chiricahuensis & Threatened \\
\hline Mountain yellow-legged frog & Rana muscosa & Endangered \\
\hline Wood frog & Rana sylvatica & Sensitive \\
\hline Kendall Warm Springs speckled dace & Rhinichthys osculus thermalis & Endangered \\
\hline Least tern & Sterna antillarum & Endangered \\
\hline Mexican spotted owl & Strix occidentalis lucida & Threatened \\
\hline Loach minnow & Tiaroga cobitis & Threatened \\
\hline Razorback sucker & Xyrauchen texanus & Endangered \\
\hline
\end{tabular}




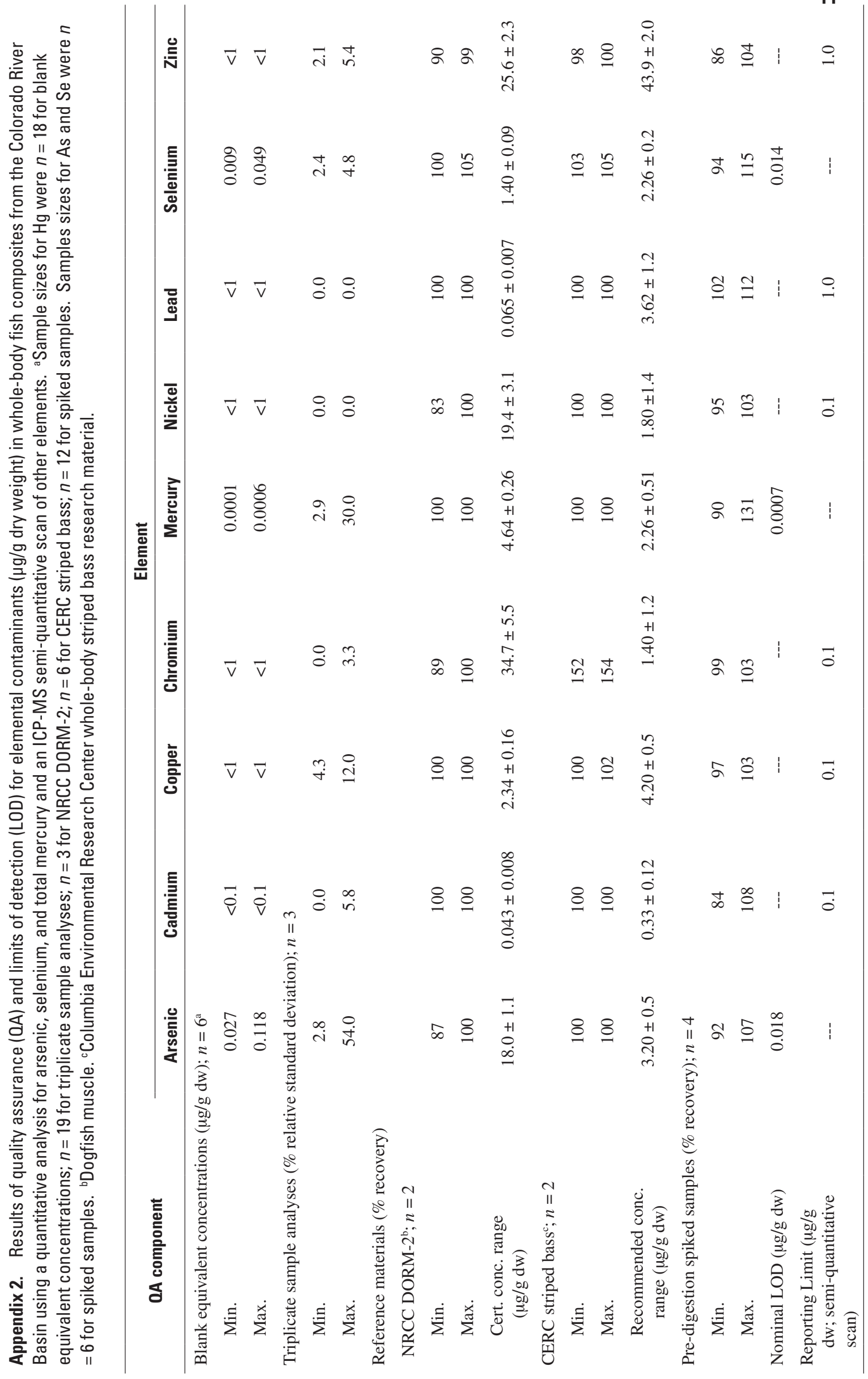




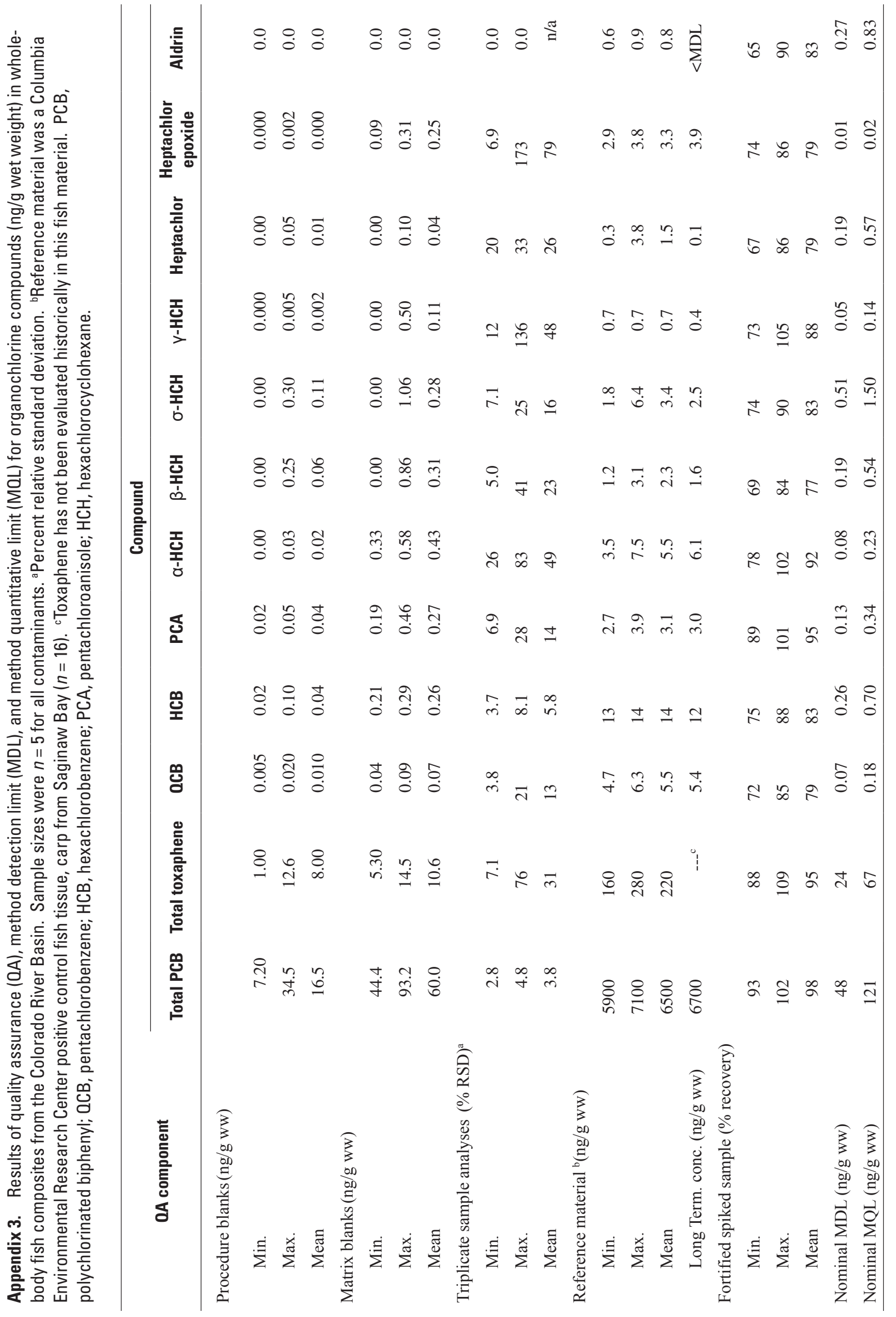




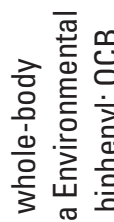

.

胥至

헝

$3 \pi$

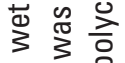

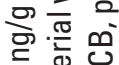

里

号

를 힌

0

음

흘 흠

등

菏

흥ㅁㄴ음

흔 혿

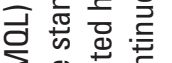

$\sum \stackrel{\pi}{\Xi} 0$

焉西

ه

잉

훙흐응

흔

흥 등응

言它

퓸

号

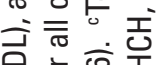

흐은

$\sum_{\text {L }} 11$ बे

E =

잉

흏흐

的空

․․․

- क ल

동 을 흔 중

E 矿式

家㲾

잉

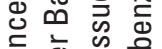

히응

ज实 호음

क 응

政范

흔 흥 흥

¿̊.

粮

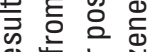

$\propto$

m.

즌 을 등

당

동 क

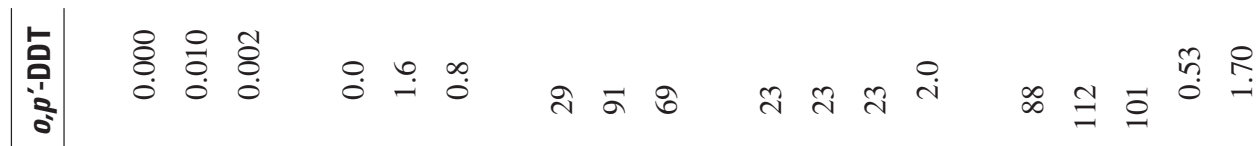

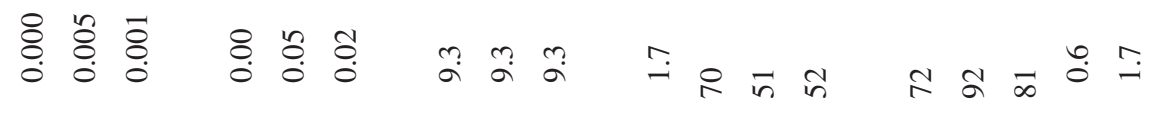

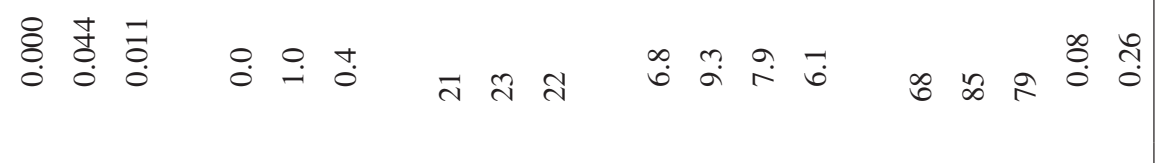

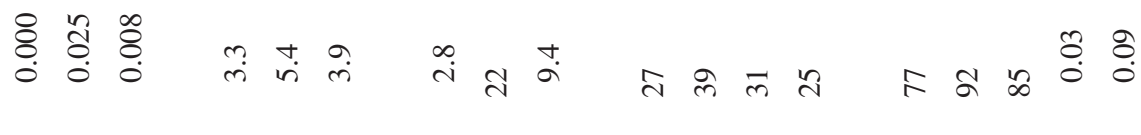

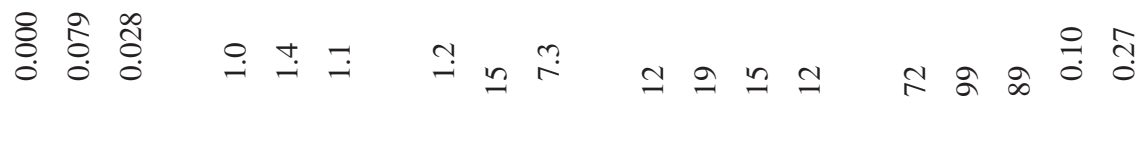

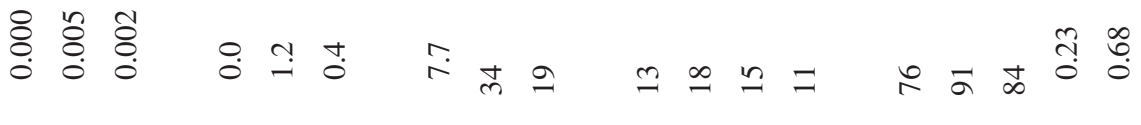

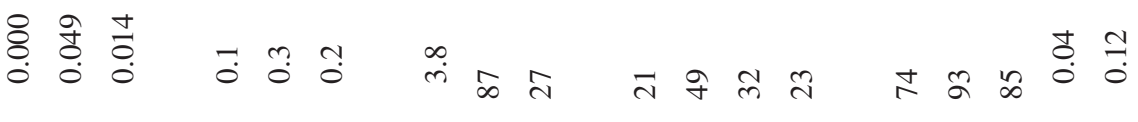

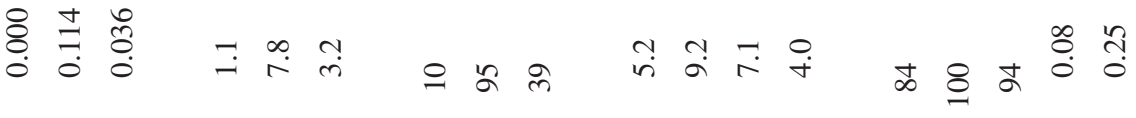

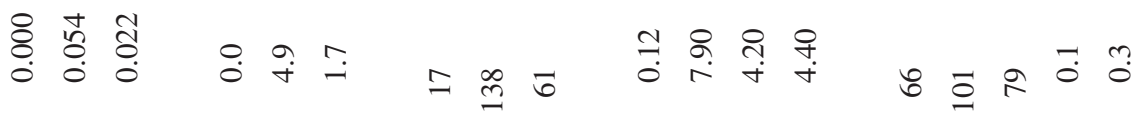

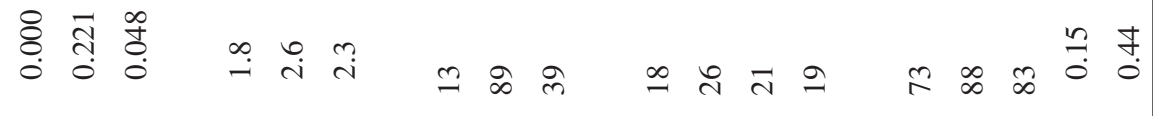

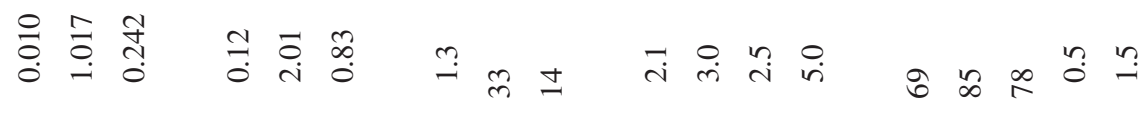

产

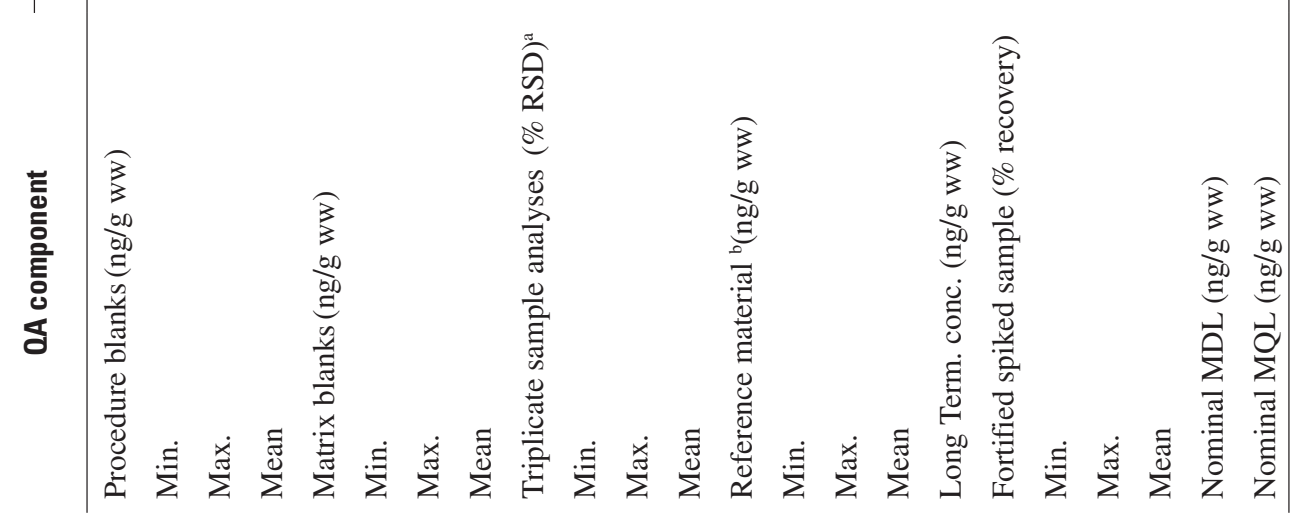




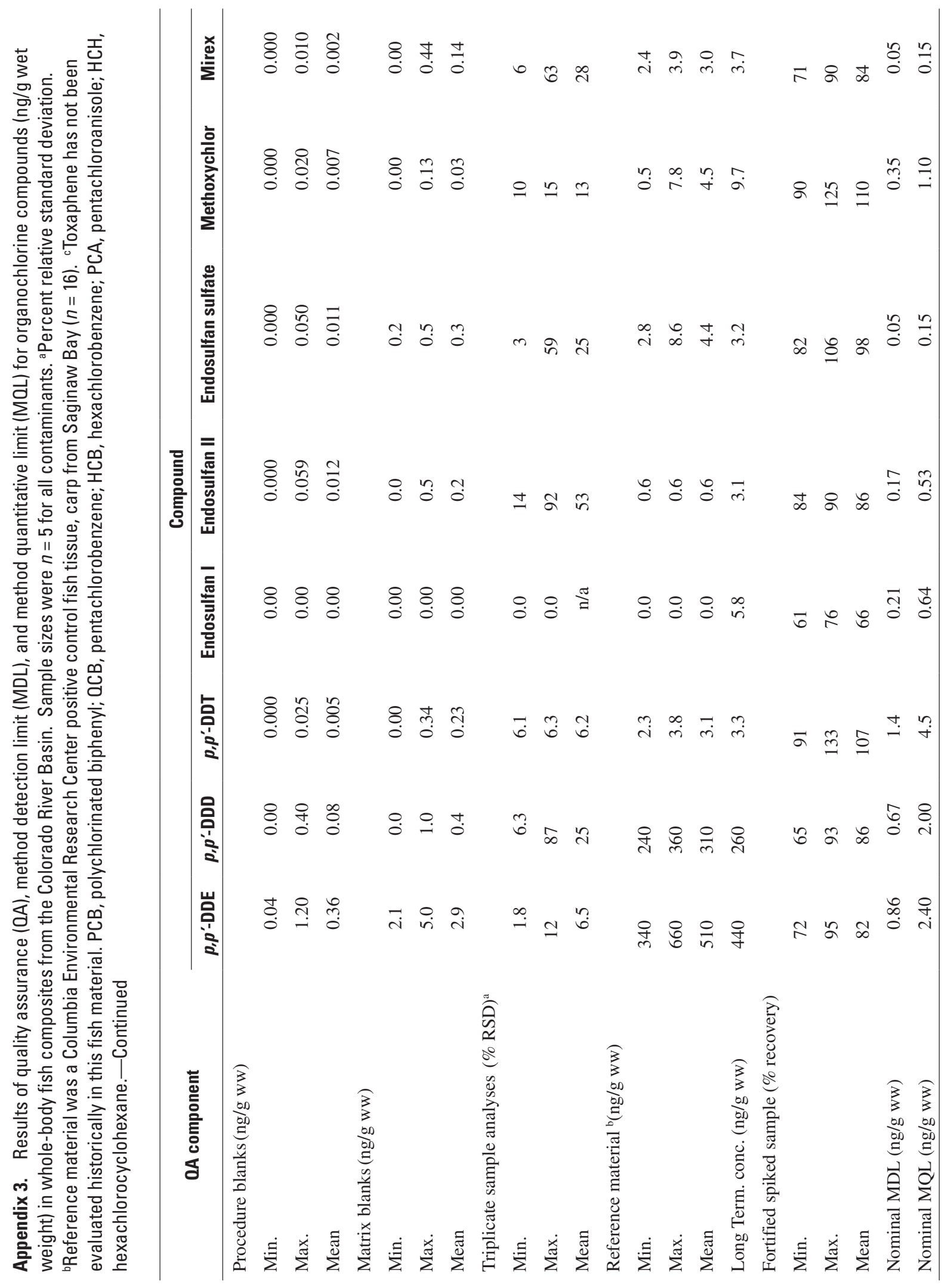




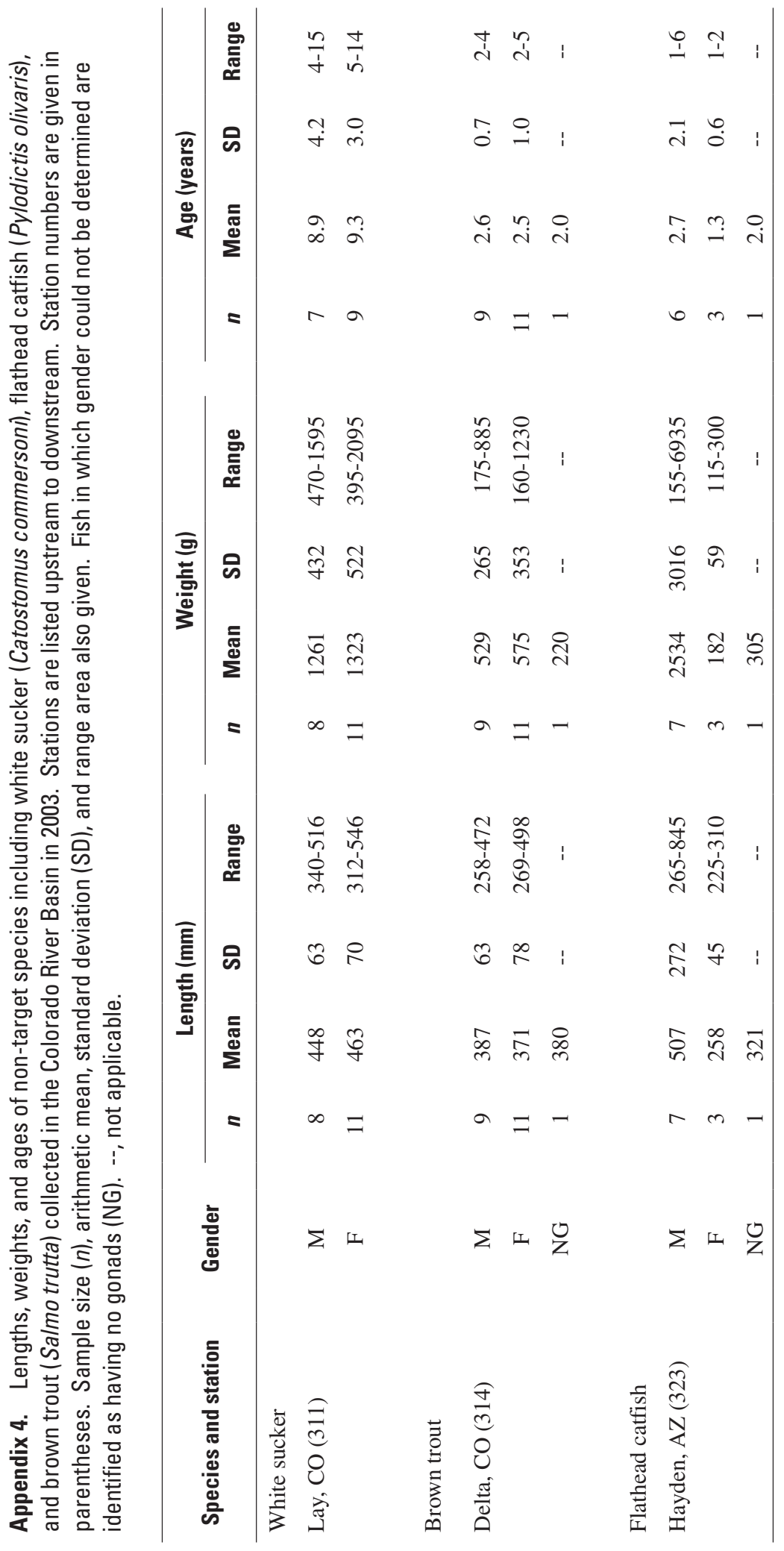




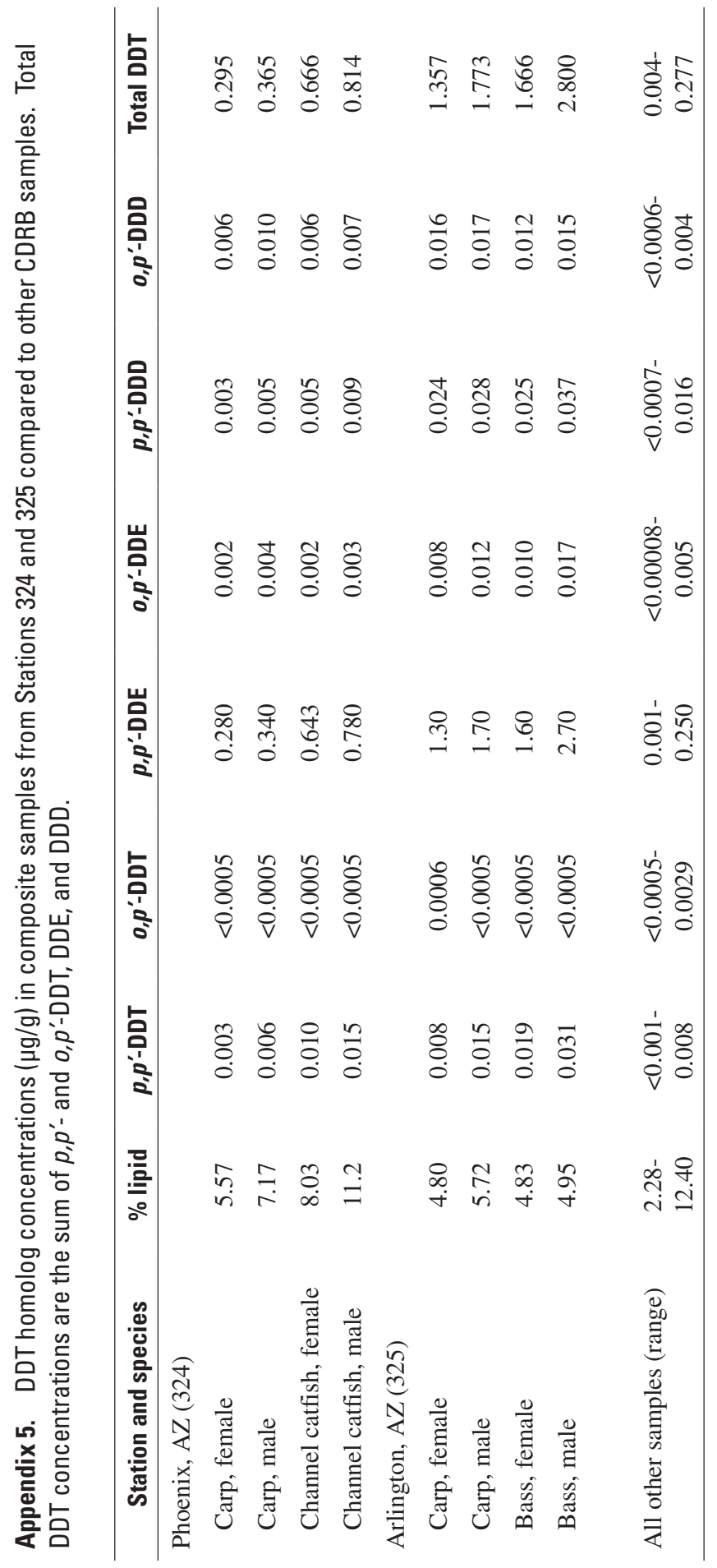


Appendix 6. Results of preliminary analysis-of-variance investigating the effects of various factors on biomarker responses in carp, bass, and channel catfish in the Colorado River Basin in 2003. Degrees-of-freedom (df), F-values with levels of significance $\left({ }^{*} 0.01<\right.$ $P \leq 0.05$; $\left.{ }^{*} P \leq 0.01\right)$, and coefficients of determination $\left(R^{2}\right)$ are presented. ND, not determined. a Data from Stations $312,315,319,320$, and 324 excluded from analysis.

\begin{tabular}{|c|c|c|c|c|c|c|c|c|c|}
\hline \multirow{2}{*}{$\begin{array}{l}\text { Variable, source, and } \\
\text { (transformation) }\end{array}$} & \multicolumn{3}{|c|}{ Carp } & \multicolumn{3}{|c|}{ Bass } & \multicolumn{3}{|c|}{ Channel Catfish } \\
\hline & df & $F$ & $\mathbf{R}^{2}$ & df & $F$ & $\mathbf{R}^{2}$ & df & $F$ & $\mathbf{R}^{2}$ \\
\hline \multicolumn{10}{|l|}{ EROD $(\log )$} \\
\hline Model & 41 & $3.45 * *$ & 0.41 & 23 & $3.78 * *$ & 0.49 & 21 & 1.17 & 0.28 \\
\hline Station & 12 & $1.81^{*}$ & & 5 & 0.60 & & 5 & 1.28 & \\
\hline Gender & 1 & 1.09 & & 1 & 1.98 & & 1 & 0.66 & \\
\hline Station*Gender & 2 & 1.47 & & 3 & 1.90 & & 3 & 0.59 & \\
\hline Stage & 1 & 0.57 & & 1 & 1.00 & & 1 & 3.88 & \\
\hline Stage*Station & 12 & 1.40 & & 4 & 0.85 & & 5 & 1.35 & \\
\hline Stage*Gender & 1 & 0.42 & & 1 & 0.15 & & 1 & 1.27 & \\
\hline Stage*Station*Gender & 2 & 1.20 & & 3 & 1.36 & & 3 & 0.62 & \\
\hline Error & 207 & & & 92 & & & 63 & & \\
\hline \multicolumn{10}{|l|}{ Condition Factor } \\
\hline Model & 41 & $1.87 * *$ & 0.27 & 23 & $5.76 * *$ & 0.60 & 21 & $6.11 * *$ & 0.67 \\
\hline Station & 12 & 1.22 & & 5 & 1.47 & & 5 & $7.45^{* *}$ & \\
\hline Gender & 1 & 0.01 & & 1 & 1.43 & & 1 & $6.41^{*}$ & \\
\hline Station*Gender & 2 & 0.00 & & 3 & 2.03 & & 3 & 0.32 & \\
\hline Stage & 1 & 0.01 & & 1 & 0.07 & & 1 & $12.25 * *$ & \\
\hline Stage*Station & 12 & 0.88 & & 4 & 1.54 & & 5 & 1.29 & \\
\hline Stage*Gender & 1 & 0.03 & & 1 & 2.02 & & 1 & $4.95^{*}$ & \\
\hline Stage*Station*Gender & 2 & 0.02 & & 3 & 1.73 & & 3 & 0.40 & \\
\hline Error & 205 & & & 92 & & & 62 & & \\
\hline \multicolumn{10}{|l|}{ Splenosomatic Index } \\
\hline Model & 24 & $2.55^{* *}$ & 0.22 & 14 & $1.86^{*}$ & 0.21 & 11 & $3.21 * *$ & 0.33 \\
\hline Station & 12 & $2.96 * *$ & & 7 & $3.56 * *$ & & 5 & $3.53 * *$ & \\
\hline Gender & 1 & $14.86 * *$ & & 1 & 0.08 & & 1 & 0.00 & \\
\hline Station*Gender & 11 & 0.98 & & 6 & 0.15 & & 5 & 0.94 & \\
\hline Error & 212 & & & 101 & & & 73 & & \\
\hline \multicolumn{10}{|l|}{ Hepatosomatic Index } \\
\hline Model & ND & ND & ND & 14 & $9.72 * *$ & 0.57 & 11 & $2.06^{*}$ & 0.24 \\
\hline Station & ND & & & 7 & $18.83^{* *}$ & & 5 & $2.69 *$ & \\
\hline Gender & ND & & & 1 & 0.50 & & 1 & 0.20 & \\
\hline Station*Gender & ND & & & 6 & 0.87 & & 5 & 0.59 & \\
\hline Error & ND & & & 101 & & & 73 & & \\
\hline \multicolumn{10}{|l|}{ HAI (rank) } \\
\hline Model & 41 & $4.05 * *$ & 0.45 & 23 & $10.62 * *$ & 0.73 & 21 & $3.07 * *$ & 0.51 \\
\hline Station & 12 & 1.34 & & 5 & $4.00 * *$ & & 5 & 1.48 & \\
\hline Gender & 1 & 0.27 & & 1 & 1.21 & & 1 & 0.20 & \\
\hline Station*Gender & 2 & 0.31 & & 3 & 2.34 & & 3 & 0.04 & \\
\hline Stage & 1 & 1.40 & & 1 & 0.17 & & 1 & 3.29 & \\
\hline Stage*Station & 12 & 1.07 & & 4 & 1.51 & & 5 & 0.78 & \\
\hline Stage*Gender & 1 & 0.03 & & 1 & 0.71 & & 1 & 0.02 & \\
\hline Stage $*$ Station $*$ Gender & 2 & 0.49 & & 3 & 2.56 & & 3 & 0.24 & \\
\hline Error & 206 & & & 92 & & & 62 & & \\
\hline
\end{tabular}


Appendix 6. Results of preliminary analysis-of-variance investigating the effects of various factors on biomarker responses in carp, bass, and channel catfish in the Colorado River Basin in 2003. Degrees-of-freedom (df), F-values with levels of significance $\left({ }^{*} 0.01<\right.$ $\left.P \leq 0.05 ;{ }^{* *} P \leq 0.01\right)$, and coefficients of determination $\left(R^{2}\right)$ are presented. ND, not determined. ${ }^{a}$ Data from Stations $312,315,319,320$, and 324 excluded from analysis. - Continued

\begin{tabular}{|c|c|c|c|c|c|c|c|c|c|}
\hline \multirow{2}{*}{$\begin{array}{c}\text { Variable, source, and } \\
\text { (transformation) }\end{array}$} & \multicolumn{3}{|c|}{ Carp } & \multicolumn{3}{|c|}{ Bass } & \multicolumn{3}{|c|}{ Channel Catfish } \\
\hline & df & $F$ & $\mathbf{R}^{2}$ & df & $\boldsymbol{F}$ & $\mathbf{R}^{2}$ & df & $\boldsymbol{F}$ & $\mathbf{R}^{2}$ \\
\hline \multicolumn{10}{|l|}{ MA- $\%(\log )^{a}$} \\
\hline Model & 11 & $3.19 * *$ & 0.43 & 19 & $4.55 * *$ & 0.57 & 11 & 0.63 & 0.13 \\
\hline Station & 7 & 1.14 & & 4 & 2.27 & & 2 & 0.34 & \\
\hline Gender & 1 & 0.13 & & 1 & 1.07 & & 1 & 0.08 & \\
\hline Station*Gender & 7 & $2.63^{*}$ & & 4 & 1.18 & & 2 & 0.28 & \\
\hline Age & 1 & $8.23 * *$ & & 1 & $6.54 *$ & & 1 & 0.32 & \\
\hline Age* Station & 7 & 0.47 & & 4 & 1.02 & & 2 & 0.03 & \\
\hline Age*Gender & 1 & 1.18 & & 1 & 2.33 & & 1 & 0.04 & \\
\hline Age*Station*Gender & 7 & 1.84 & & 4 & 0.34 & & 2 & 0.25 & \\
\hline Error & 130 & & & 65 & & & 45 & & \\
\hline \multicolumn{10}{|l|}{ MA-A $(\log )^{a}$} \\
\hline Model & 11 & $1.92 * *$ & 0.31 & 19 & $1.76^{*}$ & 0.34 & 11 & 0.43 & 0.09 \\
\hline Station & 7 & 1.54 & & 4 & 1.27 & & 2 & 0.28 & \\
\hline Gender & 1 & 1.85 & & 1 & 0.10 & & 1 & 0.81 & \\
\hline Station*Gender & 7 & 1.02 & & 4 & 0.11 & & 2 & 0.04 & \\
\hline Age & 1 & 2.81 & & 1 & 0.50 & & 1 & 0.06 & \\
\hline Age* Station & 7 & 1.58 & & 4 & 0.21 & & 2 & 0.17 & \\
\hline Age*Gender & 1 & 0.11 & & 1 & 0.62 & & 1 & 0.38 & \\
\hline Age $*$ Station $*$ Gender & 7 & 0.41 & & 4 & 0.12 & & 2 & 0.03 & \\
\hline Error & 130 & & & 65 & & & 45 & & \\
\hline \multicolumn{10}{|l|}{ MA-\#а } \\
\hline Model & 11 & $2.98 * *$ & 0.42 & 19 & $3.75 * *$ & 0.53 & 11 & 1.06 & 0.21 \\
\hline Station & 7 & 1.09 & & 4 & 1.53 & & 2 & 0.02 & \\
\hline Gender & 1 & 3.78 & & 1 & 0.06 & & 1 & 0.09 & \\
\hline Station*Gender & 7 & 1.98 & & 4 & 1.34 & & 2 & 0.07 & \\
\hline Age & 1 & 1.84 & & 1 & $5.84 *$ & & 1 & 0.59 & \\
\hline Age*Station & 7 & 0.11 & & 4 & 2.68 & & 2 & 0.19 & \\
\hline Age*Gender & 1 & 2.94 & & 1 & 0.03 & & 1 & 0.05 & \\
\hline Age $*$ Station $*$ Gender & 7 & 1.16 & & 4 & 0.39 & & 2 & 0.08 & \\
\hline Error & 130 & & & 65 & & & 45 & & \\
\hline \multicolumn{10}{|l|}{ Gonadosomatic Index } \\
\hline Model & 42 & $19.37 * *$ & 0.81 & 23 & $60.61 * *$ & 0.94 & 21 & $7.90^{* *}$ & 0.73 \\
\hline Station & 11 & $2.20^{*}$ & & 5 & $5.91 * *$ & & 5 & $4.34 * *$ & \\
\hline Gender & 1 & 2.48 & & 1 & $14.60^{* *}$ & & 1 & $5.05^{*}$ & \\
\hline Station*Gender & 2 & $3.06^{*}$ & & 3 & $4.50 * *$ & & 3 & $3.13^{*}$ & \\
\hline Stage & 1 & $23.66^{* *}$ & & 1 & 0.01 & & 1 & $22.37 * *$ & \\
\hline Stage*Station & 11 & $2.55^{* *}$ & & 4 & 1.47 & & 5 & $3.98^{* *}$ & \\
\hline Stage*Gender & 1 & $7.27 * *$ & & 1 & 0.01 & & 1 & $16.92^{* *}$ & \\
\hline Stage*Station*Gender & 1 & 2.32 & & 3 & 0.29 & & 3 & $2.83^{*}$ & \\
\hline Error & 195 & & & 91 & & & 60 & & \\
\hline
\end{tabular}


Appendix 6. Results of preliminary analysis-of-variance investigating the effects of various factors on biomarker responses in carp, bass, and channel catfish in the Colorado River Basin in 2003. Degrees-of-freedom (df), F-values with levels of significance $\left({ }^{*} 0.01<\right.$ $P \leq 0.05$; $\left.{ }^{* *} P \leq 0.01\right)$, and coefficients of determination $\left(R^{2}\right)$ are presented. ND, not determined. ${ }^{a}$ Data from Stations $312,315,319,320$, and 324 excluded from analysis. - Continued

\begin{tabular}{|c|c|c|c|c|c|c|c|c|c|}
\hline \multirow{2}{*}{$\begin{array}{c}\text { Variable, source, and } \\
\text { (transformation) }\end{array}$} & \multicolumn{3}{|c|}{ Carp } & \multicolumn{3}{|c|}{ Bass } & \multicolumn{3}{|c|}{ Channel Catfish } \\
\hline & df & $\boldsymbol{F}$ & $\mathbf{R}^{2}$ & df & $\boldsymbol{F}$ & $\mathbf{R}^{2}$ & df & $\boldsymbol{F}$ & $\mathbf{R}^{2}$ \\
\hline \multicolumn{10}{|l|}{ Vitellogenin (log) } \\
\hline Model & 41 & $23.33 * *$ & 0.83 & 23 & $7.65 * *$ & 0.66 & ND & ND & ND \\
\hline Station & 12 & $2.29 * *$ & & 5 & 1.73 & & ND & & \\
\hline Gender & 1 & 0.60 & & 1 & 1.75 & & ND & & \\
\hline Station $*$ Gender & 2 & 0.01 & & 3 & $3.30 *$ & & ND & & \\
\hline Stage & 1 & 0.01 & & 1 & 0.07 & & ND & & \\
\hline Stage $*$ Station & 12 & 1.78 & & 4 & 1.48 & & ND & & \\
\hline Stage*Gender & 1 & $8.68 *$ & & 1 & 0.11 & & ND & & \\
\hline Stage*Station $*$ Gender & 2 & 0.50 & & 3 & 2.31 & & ND & & \\
\hline Error & 199 & & & 89 & & & ND & & \\
\hline \multicolumn{10}{|l|}{ Estradiol } \\
\hline Model & 41 & $30.56 * *$ & 0.86 & 23 & $8.65 * *$ & 0.69 & 21 & $3.07 * *$ & 0.51 \\
\hline Station & 12 & $2.52 * *$ & & 5 & 0.34 & & 5 & 0.64 & \\
\hline Gender & 1 & $6.37 * *$ & & 1 & 0.36 & & 1 & 1.10 & \\
\hline Station*Gender & 2 & $2.77 *$ & & 3 & 0.53 & & 3 & 1.40 & \\
\hline Stage & 1 & 1.73 & & 1 & 0.08 & & 1 & 1.13 & \\
\hline Stage* Station & 12 & $2.40 * *$ & & 4 & 0.16 & & 5 & 0.90 & \\
\hline Stage*Gender & 1 & 0.88 & & 1 & 0.00 & & 1 & 0.49 & \\
\hline Stage*Station*Gender & 2 & 2.12 & & 3 & 0.46 & & 3 & 1.45 & \\
\hline Error & 206 & & & 88 & & & 61 & & \\
\hline \multicolumn{10}{|l|}{ 11-ketotestosterone } \\
\hline Model & 41 & $6.94 * *$ & 0.58 & 23 & $15.63^{* *}$ & 0.80 & 21 & $7.73 * *$ & 0.73 \\
\hline Station & 12 & 1.38 & & 5 & $2.24 *$ & & 5 & $3.52 * *$ & \\
\hline Gender & 1 & $11.48 * *$ & & 1 & $8.08 * *$ & & 1 & $5.19 *$ & \\
\hline Station $*$ Gender & 2 & $5.18^{*}$ & & 3 & 0.12 & & 3 & 2.55 & \\
\hline Stage & 1 & 1.57 & & 1 & 1.85 & & 1 & 0.06 & \\
\hline Stage $*$ Station & 12 & 0.84 & & 4 & 0.53 & & 5 & 0.35 & \\
\hline Stage*Gender & 1 & $6.24 *$ & & 1 & 0.01 & & 1 & 2.78 & \\
\hline Stage $*$ Station $*$ Gender & 2 & $3.85^{*}$ & & 3 & 0.22 & & 3 & 0.90 & \\
\hline Error & 206 & & & 88 & & & 61 & & \\
\hline \multicolumn{10}{|l|}{ Estradiol/11-ketotestosterone } \\
\hline Model & 41 & $7.65 * *$ & 0.63 & 23 & $6.08 * *$ & 0.61 & 21 & $2.39 * *$ & 0.45 \\
\hline Station & 12 & 0.58 & & 5 & 0.15 & & 5 & 0.59 & \\
\hline Gender & 1 & 2.15 & & 1 & 3.61 & & 1 & 0.22 & \\
\hline Station*Gender & 2 & 0.36 & & 3 & 0.11 & & 3 & 0.52 & \\
\hline Stage & 1 & 0.37 & & 1 & 0.12 & & 1 & 0.25 & \\
\hline Stage $*$ Station & 12 & 0.56 & & 4 & 0.06 & & 5 & 0.57 & \\
\hline Stage*Gender & 1 & 0.18 & & 1 & 0.14 & & 1 & 0.01 & \\
\hline Stage*Station*Gender & 2 & 0.17 & & 3 & 0.08 & & 3 & 0.15 & \\
\hline Error & 206 & & & 88 & & & 61 & & \\
\hline
\end{tabular}


Appendix 6. Results of preliminary analysis-of-variance investigating the effects of various factors on biomarker responses in carp, bass, and channel catfish in the Colorado River Basin in 2003. Degrees-of-freedom (df), $F$-values with levels of significance $\left(^{*} 0.01<\right.$ $P \leq 0.05$; $\left.{ }^{* *} P \leq 0.01\right)$, and coefficients of determination $\left(R^{2}\right)$ are presented. ND, not determined. ${ }^{a}$ Data from Stations $312,315,319,320$, and 324 excluded from analysis.-Continued

\begin{tabular}{|c|c|c|c|c|c|c|c|c|c|}
\hline \multirow{2}{*}{$\begin{array}{l}\text { Variable, source, and } \\
\text { (transformation) }\end{array}$} & \multicolumn{3}{|c|}{ Carp } & \multicolumn{3}{|c|}{ Bass } & \multicolumn{3}{|c|}{ Channel Catfish } \\
\hline & df & $\boldsymbol{F}$ & $\mathbf{R}^{2}$ & df & $\boldsymbol{F}$ & $\mathbf{R}^{2}$ & df & $\boldsymbol{F}$ & $\mathbf{R}^{2}$ \\
\hline \multicolumn{10}{|l|}{ Atresia (females only) ${ }^{a}$} \\
\hline Model & 23 & 1.62 & 0.39 & 12 & $5.46^{* *}$ & 0.68 & 10 & 1.53 & 0.54 \\
\hline Station & 3 & 0.12 & & 0 & ND & & 1 & 0.12 & \\
\hline Stage & 1 & 0.12 & & 1 & $15.84 * *$ & & 1 & 0.66 & \\
\hline Stage* Station & 3 & 0.09 & & 0 & ND & & 1 & 0.29 & \\
\hline Age & 1 & 0.00 & & 1 & $10.25 * *$ & & 1 & 0.22 & \\
\hline Age*Station & 3 & 0.11 & & 0 & ND & & 1 & 0.10 & \\
\hline Stage*Age & 1 & 0.01 & & 1 & $15.29 * *$ & & 1 & 0.50 & \\
\hline Stage*Age* Station & 3 & 0.11 & & 0 & ND & & 1 & 0.19 & \\
\hline Error & 59 & & & 31 & & & 13 & & \\
\hline
\end{tabular}




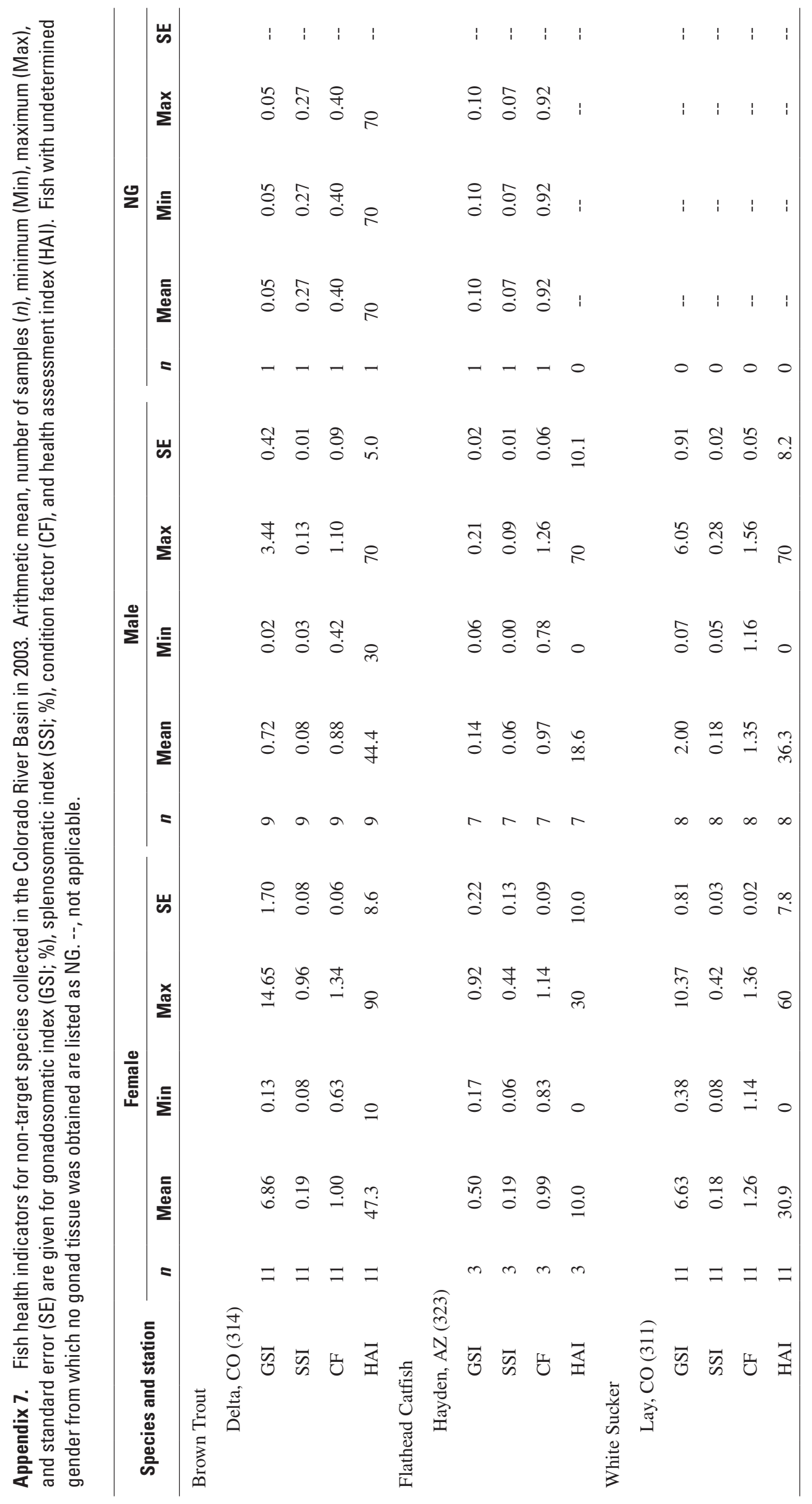


